\title{
U.S. Job Creation Due to Nuclear Power Resurgence in the United States
}

\section{Volumes 1 and 2}

C. R. Kenley

R. D. Klingler

C. M. Plowman

R. Soto

R. J. Turk

R. L. Baker

S. A. Close

V. L. McDonnell

S. W. Paul

L. R. Rabideau

S. S. Rao

B. P. Reilly

November 2004

Idaho National Engineering and Environmental Laboratory Bechtel BWXT Idaho, LLC 
INEEL/EXT-04-02384

\title{
U.S. Job Creation Due to Nuclear Power Resurgence in the United States
}

\section{Volumes 1 and 2}

\author{
C. R. Kenley ${ }^{1}$ \\ R. D. Klingler ${ }^{1}$ \\ C. M. Plowman ${ }^{1}$ \\ R. Soto ${ }^{1}$ \\ R. J. Turk ${ }^{1}$ \\ R. L. Baker ${ }^{2}$ \\ S. A. Close ${ }^{2}$ \\ V. L. McDonnell ${ }^{2}$ \\ S.W. Paul ${ }^{2}$ \\ L. R. Rabideau ${ }^{2}$ \\ S. S. Rao ${ }^{2}$ \\ B. P. Reilly ${ }^{2}$
}

${ }^{1}$ INEEL

${ }^{2}$ Bechtel Power Corp.

November 2004

Idaho National Engineering and Environmental Laboratory Idaho Falls, Idaho 83415

Bechtel Power Corporation

Frederick, Maryland 21703

Prepared for the

U.S. Department of Energy

Office of Nuclear Energy, Science, and Technology

Under DOE Idaho Operations Office

Contract DE-AC07-99ID13727 


\section{U.S. Job Creation Due to Nuclear Power Resurgence in The United States - Volume 1}

November 2004

Idaho National Engineering and Environmental Laboratory Bechtel BWXT Idaho, LLC 
INEEL/EXT-04-02384

Volume 1

\title{
U.S. Job Creation Due to Nuclear Power Resurgence in the United States - Volume 1
}

\author{
INEEL Bechtel Power Corp. \\ C.R. Kenley* \\ R.D. Klingler \\ R.L. Baker \\ C.M. Plowman \\ S.A. Close \\ V.L. McDonnell \\ R. Soto \\ S.W. Paul \\ R.J. Turk \\ L.R. Rabideau \\ S.S. Rao \\ B.P. Reilly
}

November 2004

\author{
Idaho National Engineering and Environmental Laboratory \\ Idaho Falls, Idaho 83415 \\ Bechtel Power Corporation \\ Frederick, Maryland 21703
}

Prepared for the

U.S. Department of Energy

Office Nuclear Energy, Science, and Technology

Under DOE Idaho Operations Office

Contract DE-AC07-99ID13727 
This page intentionally left blank. 


\section{SIGNATURES OF APPROVAL}

Originator:

Catherine Plowman

Date

Project Manager

Reviewers:

Finis Southworth, Ph.D.

Date

Manager, Systems and Decision Sciences

Date

James Wolf, Ph.D. 
This page intentionally left blank. 


\begin{abstract}
The recent revival of interest in nuclear power is causing a reexamination of the role of nuclear power in the United States. This renewed interest has led to questions regarding the capability and capacity of current U.S. industries to support a renewal of nuclear power plant deployment. This study was conducted to provide an initial estimate of jobs to be gained in the U.S. through the repatriation of the nuclear manufacturing industry. In the course of the study, related job categories were also modeled to provide an additional estimate of the potential expansion of existing industries (i.e., plant construction and operations) in conjunction with the repatriation of manufacturing jobs.
\end{abstract}


This page intentionally left blank. 


\section{Executive Summary}

Over 200 nuclear power units were ordered in the United States during the late 1960s and 1970s ${ }^{1}$, causing a significant expansion of employment and manufacturing capability in the nation. Architectengineers, constructors, nuclear steam system suppliers, component suppliers, and nuclear fuel production all rapidly expanded to meet the needs.

Starting in the mid-70s, several factors contributed to the changing nature of the nuclear industry. These factors included incidents such as the Brown's Ferry fire in 1975, the Three Mile Island Accident in 1979, and the Chernobyl accident in 1986, were one of those contribution factors. In addition, the oil embargo in force during the same period (a time when the electrical demand had been growing at a rate $7 \%-8 \%$ a year) forced the country to rethink energy usage policies. After the embargo, a growth rate of $2 \%$ per year was the norm. Reduced electrical demands and projections, eroded public confidence, growing regulatory uncertainty, delayed plant start-ups, and ballooning plant costs all contributed to a lack of orders for new plants.

In response, companies supplying goods and services to the U.S. nuclear industry worked off the backlog of U.S. orders for nuclear power units and either transitioned to support new foreign orders or dropped out of the industry all together. The lack of domestic orders and relatively small numbers of foreign orders caused the U.S. nuclear supply industry to undergo a drastic contraction in the late 1980s and 1990s. There were no new orders in the U.S.; work slowed on the existing orders, causing some of the existing orders to be cancelled; and some existing plants were abandoned or scheduled for decommissioning (e.g., Zimmer, Marble Hill, Bellafonte, Yankee Rowe, Rancho Seco, etc.).

The recent revival of interest in nuclear power is causing a reexamination of the role of nuclear power in this country. This renewed interest has led to questions regarding the capability and capacity of current U.S. industries to support a renewal of nuclear power plant deployment. This study was conducted to provide an initial estimate of jobs to be gained in the U.S. through the repatriation of the nuclear manufacturing industry. In the course of the study, related job categories were also modeled to provide an additional estimate of the potential expansion of existing industries (i.e., plant construction and operations) in conjunction with the repatriation of manufacturing jobs.

The framework adopted for this initial study can be summarized as follows:

Deploying 33 to 41 new Generation III units, ranging in capacity from 1200 to 1500 megawatts (MWe), will meet an estimated demand of 50,000 MWe of new generating capacity by 2020. Construction of the first unit is assumed to begin in 2009 .

The results from the model show that approximately 610,000 jobs would be added to the U.S. economy by

- Repatriating 37,000 to 38,000 nuclear manufacturing jobs

- Adding 72,000 to 79,000 plant construction and operations jobs

- Adding another 181,000 to 250,000 Indirect Jobs in the nuclear power industry

- Inducing an additional 218,000 to 242,000 jobs in the non-nuclear industries throughout the country.

1 “The Changing Structure of the Electric Power Industry: An Update," Energy Information Administration (EIA), Dec 1996, Appendix A, p. 109 and 110. 
This page intentionally left blank. 


\section{CONTENTS}

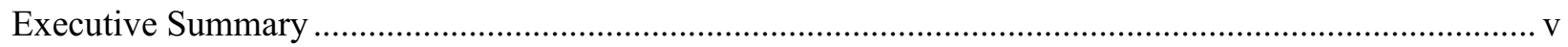

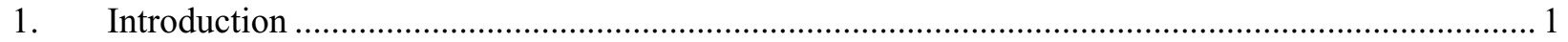

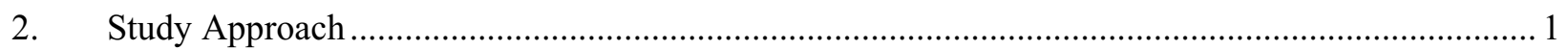

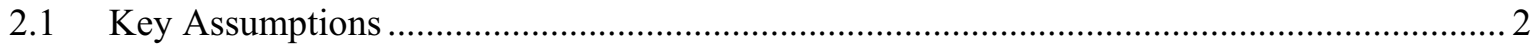

2.2 Collection and Evaluation of Existing Data ...................................................................... 5

2.3 Development of the Macroeconomic Model......................................................................

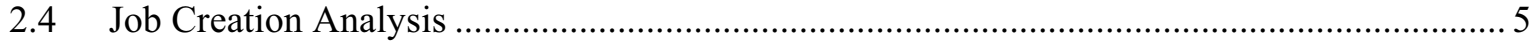

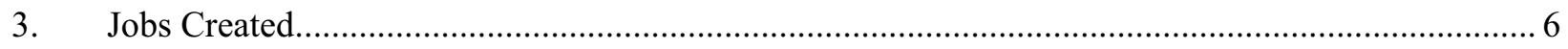

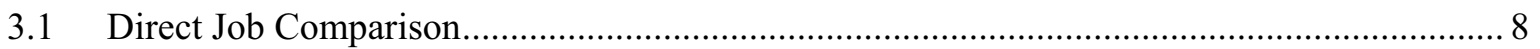

3.2 Direct, Indirect, and Induced Job Comparison................................................................ 9

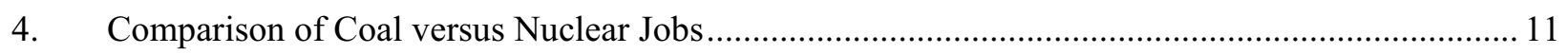

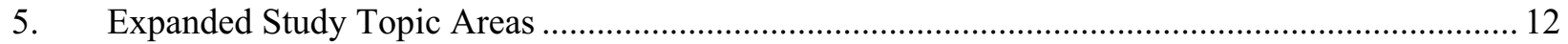

\section{FIGURES}

Figure 1. Estimate of New Operational Plants by Year ........................................................................ 3

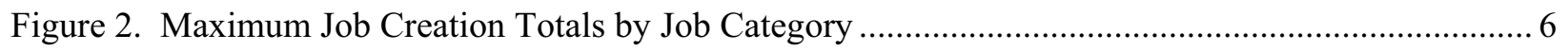

Figure 3. Growth of Direct Jobs over Study Timeframe …............................................................. 7

Figure 4. Growth of Indirect plus Induced Jobs over Study Timeframe............................................... 8

Figure 5. Direct Jobs Due to 33 1500-MWe Units over 15 Years ........................................................ 8

Figure 6. Direct Jobs Due To 41 1200-MWe Plants Over 15 Years....................................................... 9

Figure 7. Direct vs. Indirect vs. Induced Jobs by Year for 1500MWe Units.......................................... 9

Figure 8. Direct vs. Indirect vs. Induced Jobs by Year for 1200-MWe Units ....................................... 10

\section{TABLES}

Table 1. New Nuclear Plant Deployment by Year............................................................................. 2

Table 2. Washington Input-Output Model Data Comparison to Study Results ...................................... 7

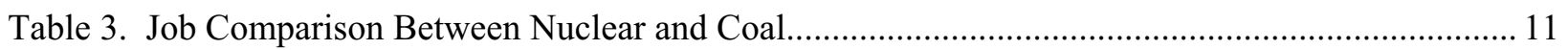


This page intentionally left blank. 


\section{Study Summary}

\section{INTRODUCTION}

This study was requested by the U.S. Department of Energy to evaluate the potential for job creation through resurgence of the commercial nuclear industry in the United States. The Idaho National Engineering and Environmental Laboratory (INEEL) and Bechtel Power Corporation collaborated to produce the enclosed information. This study provides an initial estimate of the potential numbers of new jobs that could be created in the United States, including those that could be repatriated from overseas, due to a resurgence of the nuclear power industry.

This Study Summary Volume (Volume 1) is accompanied by a larger, more detailed volume. Volume 2 contains three major appendices: Bechtel Power Corporation's report, Study of the Impact on Domestic Manufacturing and Supply Infrastructure Resulting from New Nuclear Plant Deployment; INEEL's data analysis and curve fitting methodologies for both the Bechtel and Nuclear Energy Institute (NEI) data used to drive the job creation model; and a description of the relationships and operations of the resultant Macroeconomic model. Broader-level descriptive information is provided below to support the conclusions and recommendations made in this volume of the report.

\section{STUDY APPROACH}

Purpose of Study. This study is focused on defining the potential new jobs created or repatriated to the United States directly attributable to a large-scale deployment of new nuclear power plants across the nation.

Input Data. Three key sources of input data were used to develop the underlying relationships used to model job repatriation and new job creation in a revitalized nuclear industry. The first input source was developed by Bechtel Power Corporation of Frederick, Maryland, directly for this study. Bechtel Power surveyed previous and potential U.S. suppliers of nuclear power plant components to identify the number of jobs they would add to meet a series of new plant orders (shown in Figure 1). Bechtel also supplied the estimate of construction jobs needed to build the new plants. The complete Bechtel Power report, Study of the Impact on Domestic Manufacturing and Supply Infrastructure Resulting from New Nuclear Plant Deployment can be found in Volume 2 of this study.

The second source of input data was from NEI. Projections of the Energy Information Administration (EIA) estimate the United States will need an additional 355,000 MWe of electricity within the next two decades to meet growing demand in this country. Based on these projections, NEI developed a vision for the nuclear power industry entitled, Nuclear Energy and the Nation's Future Prosperity, which assumes that $60,000 \mathrm{MWe}$ of this new demand will be provided by nuclear sources: $10,000 \mathrm{MWe}$ through extension and efficiencies in the current plants and 50,000 MWe through new generation capacity. This report is the foundation of NEI's Vision 2020 initiative and represents the views of over 260 nuclear energy and technology firms.

The third source of data was the Dominion Energy 'Constructability Study' formally titled, Study of Construction Technologies and Schedules, O\&M Staffing and Cost, Decommissioning Costs and Funding Requirements for Advanced Reactors. The specific advance reactor staffing figures were used to augment NEI data to create an Operations Jobs estimation function for this study.

In addition to the Vision 2020 framework, this study also used a compendium of NEI economic impact studies of existing nuclear power plants and their effects on the regional economies in terms of permanent plant operations jobs, subcontracted Indirect Jobs, and non-nuclear jobs induced into the U.S. 
economy. These data provided the critical link between jobs repatriated in the nuclear manufacturing sector and new job expansion in existing industries due to the deployment of new nuclear power plants.

Results. The results of this study are reported in five job categories: repatriated manufacturing jobs, power plant construction jobs, plant operations jobs, indirect plant jobs, and non-nuclear jobs induced into the economy. Each of these categories is defined in Section 3.1. To allow for ease of comparison between this study's results and other job prediction reports, these five job categories are combined into three common families: Direct Jobs, Indirect Jobs, and Induced jobs. The Direct Job family is the sum of construction, manufacturing, and operations jobs. In addition to showing results grouped in these three categories, the manufacturing jobs are also reported separately to highlight the difference between repatriating the lost manufacturing jobs versus expanding the existing construction and operations sectors.

\subsection{Key Assumptions}

Timeframe of Study. The timeframe for this study is from 2009, with the first order for a new plant, to 2024, when a steady state of plant orders has been reached and the 50,000 MWe of electricity assumed in Vision 2020 have been achieved. A five-year construction period is also assumed. Consequently, a new plant ordered in 2009 becomes operational in 2014.

Types and Numbers of Plants. To establish a conservative job creation scenario, two alternatives were used to bound this study and meet the 50,000 MWe goal: (1) 33 single-unit, 1500megawatt plants, and (2) 41 single-unit, 1200-megawatt plants, as shown in the Table 1. This is consistent with NEI's Vision 2020 scenario shown in Figure 1.

Table 1. New Nuclear Plant Deployment by Year

\begin{tabular}{|c|c|c|}
\hline Year & \# of 1200 MW units deployed & \# of 1500 MW units deployed \\
\hline 2014 & 1 & 1 \\
\hline 2015 & 2 & 2 \\
\hline 2016 & 3 & 2 \\
\hline 2017 & 3 & 2 \\
\hline 2018 & 4 & 3 \\
\hline 2019 & 4 & 3 \\
\hline 2020 & 4 & 4 \\
\hline 2021 & 5 & 4 \\
\hline 2022 & 5 & 4 \\
\hline 2023 & 5 & 4 \\
\hline 2024 & 5 & 4 \\
\hline TOTAL & $\mathbf{4 1}$ & $\mathbf{3 3}$ \\
\hline
\end{tabular}

It is recognized that other combinations of unit capacity and number of units could also be deployed to meet the 50,000 MWe demand (50 units of 1,000 MW each, or 125 units of $400 \mathrm{MW}$ each). For simplicity, two generic units of 1200 and $1500 \mathrm{MWe}$, respectively, and deployed as single unit plants were used in this study. In keeping with the conservative nature of this study, the higher capacity units meant fewer plants being built and lower numbers of jobs being created.

The NEI economic impact data from recent studies of operational plants were combined with Dominion Energy's Study of Construction Technologies and Schedules, O\&M Staffing and Cost, Decommissioning Costs and Funding Requirements for Advanced Reactors O\&M staffing projections to 
develop the Operations Jobs function for a generic plant. Once completed, a good correlation was observed between the composite function and the Dominion Energy data. For instance, the Dominion Energy Study projected that a new single-unit AP1000 plant would require 647 total plant staff. The model in this study estimated that 677 permanent workers would be needed for a similar generic, singleunit, 1100MWe plant. Volume 2, Appendix B, has more detailed information on all of the job estimation functions.

Life Cycle Stages Considered. The enclosed study starts with the assumption that new power plant orders have been placed and considers those jobs that are part of the construction, equipment manufacturing, operations, and servicing of the new plants. The study also looks at the non-nuclear power jobs induced into the economy to support the nuclear jobs. Notably missing are the jobs that could be created and/or repatriated for the design, siting, licensing, oversight, waste management, decontamination and decommissioning, and other related endeavors. Instead, given the time permitted, this initial study focused on the growth impacts on the most immediate categories of jobs due to repatriation or creation. An expanded study that takes into account these other job categories is recommended to further refine the results reported here.

Number of New Nuclear Power Plants. In the report, Nuclear Energy and the Nation's Future Prosperity (Vision 2020), NEI assumes that 50,000 MWe of electrical power generated by new nuclear sources will be needed, in addition to growing fossil and renewable sources, to meet the power demands of the year 2020. For the purposes of this study, the demand stated in Vision 2020 was translated to start in 2014, coinciding with the latest thinking on the licensing and approvals required for new nuclear plants, and extend for 20 years. The types of advanced reactors expected to provide this additional electricity are capable of $1200 \mathrm{MWe}$ to $1500 \mathrm{MWe}$ per generic unit. That equates to a need for 33 to 41 new nuclear power units by the year 2020. Beyond 2020, it is estimated that four to five new plants will have to be added to the inventory every year to keep pace with continued growth in the demand for electricity. The deployment of new plants to meet these needs through 2024 is shown in Figure 1. The estimate of new plants was not based on any particular design but, instead, represents a potential range of power generation capabilities.

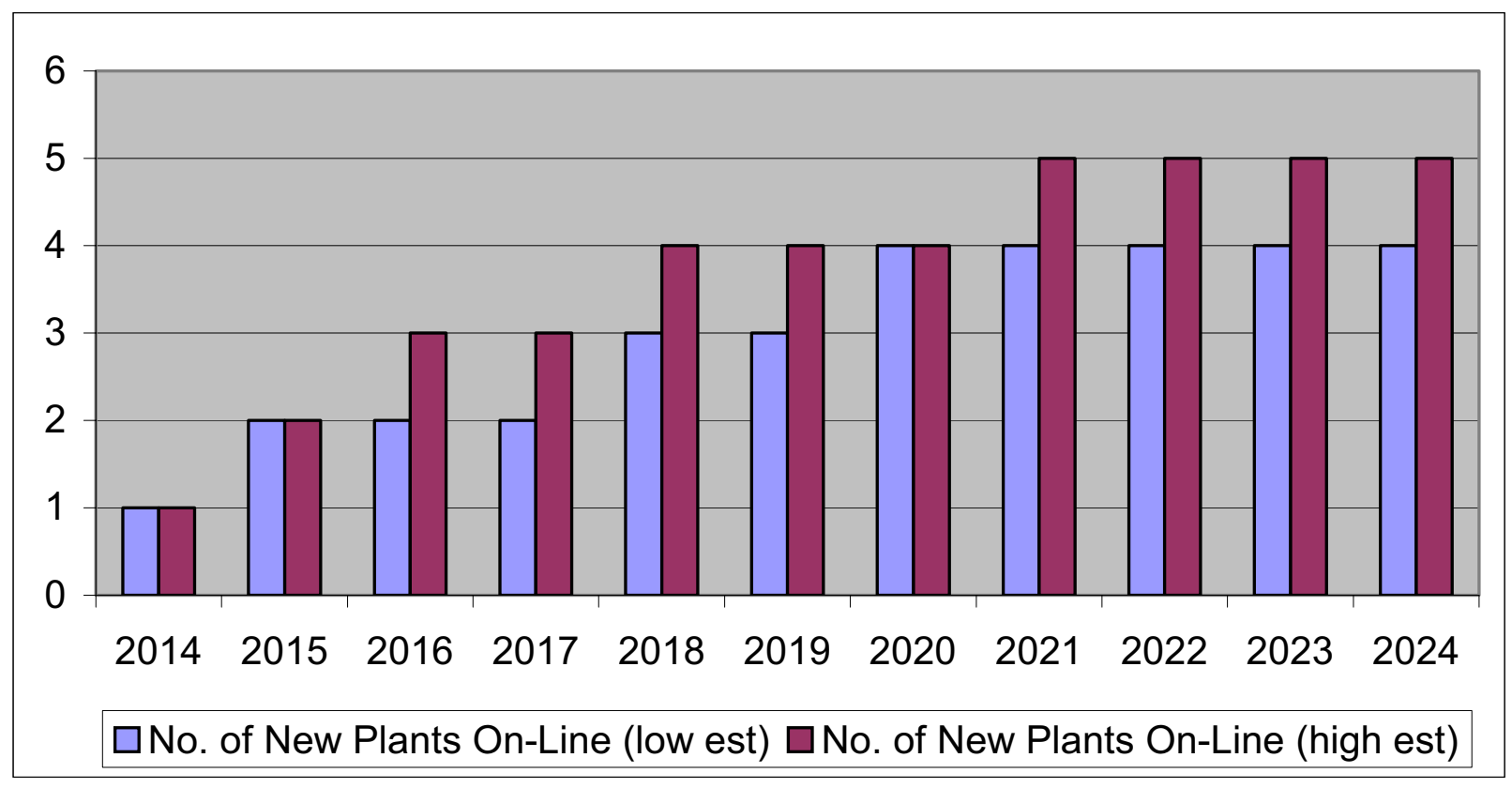

Figure 1. Estimate of New Operational Plants by Year 
Repatriated Manufacturing Jobs. This job category refers to those jobs previously lost to either offshore companies or industry attrition due to the lack of nuclear plant orders in the United States. It was assumed that job repatriation would first occur in the manufacturing sector under the Vision 2020 scenario. Bechtel Power Corporation conducted a study of potential suppliers for nuclear plant equipment to determine how many jobs those first tier suppliers might add if new nuclear plant orders were received. These suppliers were given the chart shown in Figure 1 and were asked to provide a table of new jobs per year from 2009 through 2024. The Bechtel Power Corporation report is included in Appendix A in Volume 2 of this study.

It is important to note that data from major suppliers of all needed equipment could not be collected in the short duration of this initial study. No suppliers of cabling, compressors, vacuum pumps, dampers/louvers, and cooling towers responded to the Bechtel Power survey. Additionally, manufacturers of large components, such as reactor vessels and steam generators, postulated they could fill the orders for what they perceived as a relatively few large components with their existing offshore capabilities and/or subcontracting relationships. To estimate a repatriation of jobs, suppliers were asked about their market share in the commodity or equipment. The market share data were used to estimate an entirely $100 \%$ U.S. production of the equipment under consideration. Appendix A in Volume 2 describes the transformation of the Bechtel survey data points into continuous functions for the modeling work. As a result of some missing data, the number of Repatriated Jobs reported in this study is considered to be very conservative.

Construction Jobs. The Bechtel Power Corporation Study also included an estimate of the labor needed to construct a new nuclear power plant. Their data were used to analyze the Direct construction jobs added due to new plant deployment. These jobs were considered to be an expansion of the construction industry.

Operations Jobs. These jobs include the higher-paying permanent plant operators, technicians, plant engineers, and managers involved in the day-to-day-operations of a nuclear power plant. The NEI has conducted several economic impact studies of existing nuclear power plants over the past several years. The NEI study data were used to formulate the number of Plant Operations jobs to be added per new plant per year. These jobs were considered to be new jobs in the existing Plant Operations sector. In addition, no consideration was given to the operations jobs running the current fleet of reactors. This assumption is based on the current plants' license being extended beyond the time frame considered in this study.

Indirect Jobs. These jobs were calculated using formulas derived from the NEI economic impact studies. For the NEI studies, the indirect employment effects for each plant were based on actual operations expenditures for all outside goods, services, and taxes. Examples of indirect expenditures include nuclear fuel; maintenance and repair services; personnel supply services; management and consulting services; industrial machinery; pipes, valves, and pipe fittings; research and testing services; engineering-architectural services; steam supply and sewage services; computer and data processing services: insurance premiums; and state and local taxes. The potential new jobs created by these expenditures are an expansion of higher paying, family-wage employment in the United States.

Induced Jobs. This job category contains the initial estimate of the new jobs created in the nonnuclear industry due to the new jobs added in the categories above and using formulas derived from the NEI studies. These jobs represent a significant impact on the employment and economy of those locales in which the new plants may be built and on the U.S. economy as a whole. (For instance, the Indian Point study reported local Induced Jobs at 918, Induced Jobs throughout New York State at 1,132, and Induced Jobs across the United States at 5,125). These types of jobs include the additional grocery store checkers, elementary school teachers, home construction craft workers, postal carriers, etc. that are added to the community as a result of new nuclear power plant employment. 
Data from NEI studies were used for the Operations, Indirect, and Induced Jobs calculations. The NEI data were developed utilizing the IMPLAN modeling tool running on U.S. Census data to determine the economic impact of operating nuclear plants at both the regional and national levels. The IMPLAN data and account structure closely follow the accounting conventions used in studies of the U.S. economy by the Department of Commerce Bureau of Economic Analysis. Data of this caliber were needed to complement the supplier data collected by the Bechtel survey and the construction data supplied by Bechtel for this study.

\subsection{Collection and Evaluation of Existing Data}

The first element of the study was the collection and analysis of existing industry and expert data from a total system perspective. Many industry-specific and labor-related studies and experiences were available as data sources; however, the complex problem stated above required integration across the various energy, manufacturing, and employment sectors to identify solutions and their respective impacts. This initial step provided a basic understanding of the relationship between the number of new plants built and number of new jobs created. The data collected by Bechtel Power Corporation during this phase of the study can be found in its entirety in the Study of the Impact on Domestic Manufacturing and Supply Infrastructure Resulting from New Nuclear Plant Deployment report included in Volume 2 of this report.

The data collected by Bechtel Power were used to define the relationships between jobs in the manufacturing and construction sectors and the number of new plants deployed. NEI data were used to develop relationships between jobs created and plants deployed in the Operations, Indirect, and Induced Jobs sectors.

\subsection{Development of the Macroeconomic Model}

The second phase of the study was the development of a macroeconomic model that incorporated the industry data uncovered in the first step. The industry data were further enhanced by information from economic impact studies performed by NEI for individual plant sites. Statistical methods for fitting a curve through the data points translated the raw data into a set of equations, which could then be used to generate graphical representations of the relationships in the construction, manufacturing, operations, and indirect sectors with respect to the jobs created in each of those areas. The input used for all of these functions within the model is the number of new nuclear power plants built and brought on line at the rate shown in Figure 1.

\subsection{Job Creation Analysis}

Based on the new nuclear plant deployment timeline shown above and using the formulas and graphical functions from the collected data, analyses were performed to estimate the numbers of new jobs created through the construction, equipment manufacturing, operations, and servicing of these new plants.

The analyses considered the upper and lower bounds for the number of new plants, as shown in Figure 1, based on the assumptions that generic 1200 or 1500 megawatt units are used to meet the 50,000 megawatt target. The upper and lower bounds of jobs created are shown in Figures $3-6$ based on the number of new plants being built. More detailed uncertainty analyses regarding both the survey data and the NEI studies should be performed. Initial uncertainty bands were created to drive a Monte Carlo simulation technique in the event uncertainty analyses are desired. Additional information on the curve fitting and other statistical methods applied to the collected data can be found in Appendix B of Volume 2 of this study. 


\section{JOBS CREATED}

A substantial number of new jobs would be created if the nuclear power industry were reinvigorated to ensure it would continue to provide a vital role in meeting the electrical demand in this country. Jobs repatriated are but a fraction of all the new jobs that would proceed from building new nuclear plants in the United States.

Figure 2 shows the maximum number of new jobs created during the $2009-2024$ timeframe for the five job categories in this study. The jobs shown here include operations jobs for the 44 plants operating in 2024 plus the 25 plants under construction in 2024, which hire and train workers three years prior to beginning operations. An estimated 38,000 repatriated manufacturing jobs would be generated. However, a cascading effect was noted whereby 79,000 new construction and operations jobs plus the 38,000 manufacturing jobs would create an additional 250,000 Indirect Jobs. The impact from these Indirect Jobs would ripple through the U.S. economy and create an additional 242,000 jobs for a total of nearly 610,000 new jobs added over the 15 -year timeframe. The result is that for each Direct construction, manufacturing, or operations job in a new nuclear power plant, four ${ }^{2}$ new jobs will be created to provide indirect goods and services to that plant or as induced non-nuclear jobs in the economy.

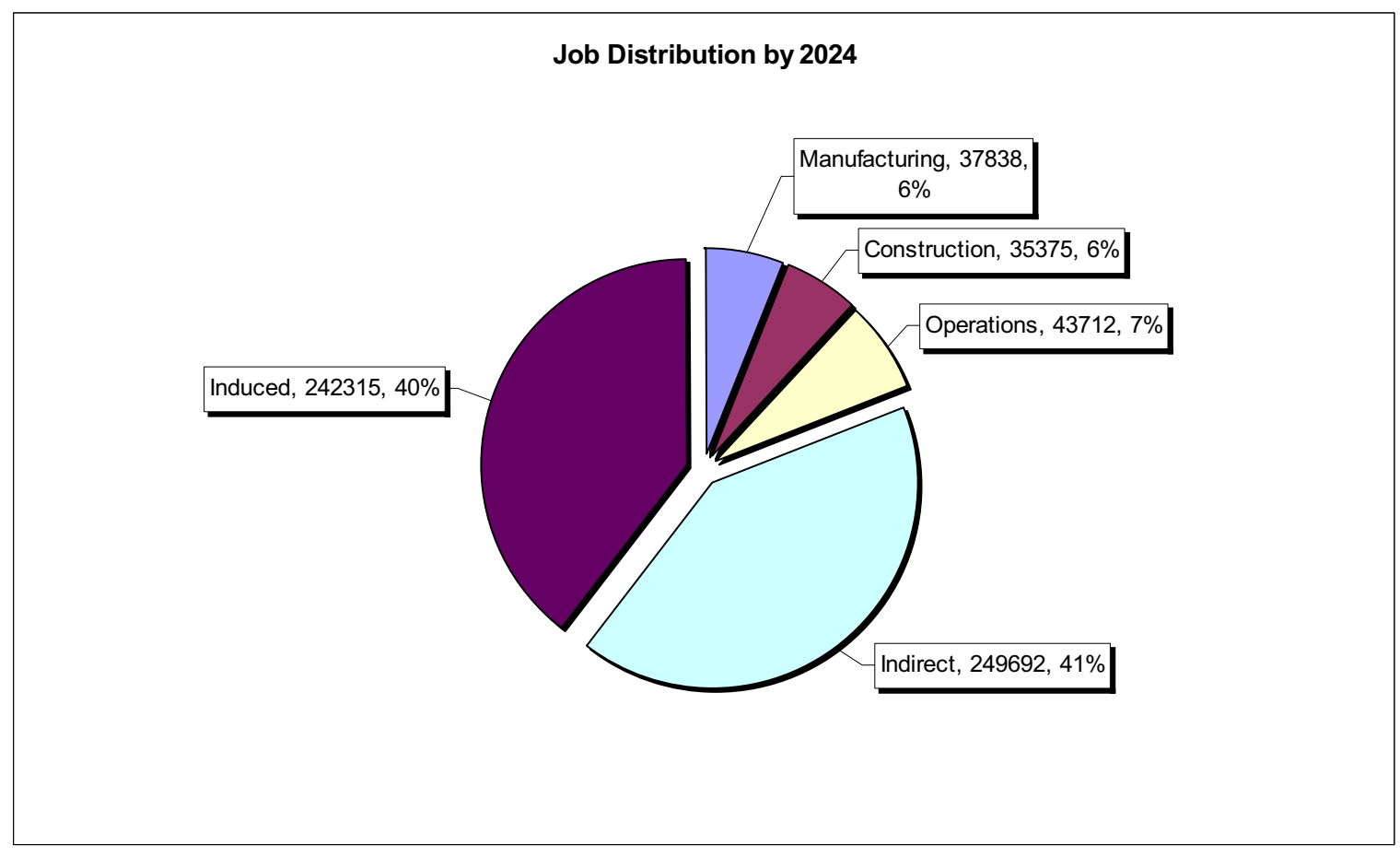

Figure 2. Maximum Job Creation Totals by Job Category

Standard economic impact prediction models for utilities were consulted to validate the results shown above. In particular, the State of Washington's Office of Financial Management recently revamped and published their 1997 Washington Input-Output Model (see www.ofm.wa.gov/economy/ for the complete study). In the Washington model, the total indirect plus induced employment per Direct construction, manufacturing, or operations job was determined. The Washington data for related

2 It is recommended the NEI data used to generate this multiplier effect be validated to ensure appropriate scaling factors are used when a new unit is added to an existing site, as compared to a unit being built at a new site. 
industries corroborate this study's results and are shown in Table 2. The 4-to-1 multiplier of Direct to Indirect/Induced Jobs seems to match well with other power utility figures. Another way to view the impact of new nuclear power plants on jobs is shown in Figures 3 and 4. Figure 3 shows the growth in Direct Jobs (construction + manufacturing + operations) over time while Figure 4 shows the growth in Indirect plus Induced Jobs over the same timeframe.

Table 2. Washington Input-Output Model Data Comparison to Study Results

\begin{tabular}{|l|c|}
\hline \multicolumn{1}{|c|}{ Industry } & Indirect plus Induced Employment Per Direct Job \\
\hline Chemicals and Products & 4.631 \\
\hline Electric Utilities & 4.948 \\
\hline Gas Utilities & 3.834 \\
\hline Other Utilities & 3.372 \\
\hline This Study's Nuclear Utilities & 4.208 \\
\hline
\end{tabular}

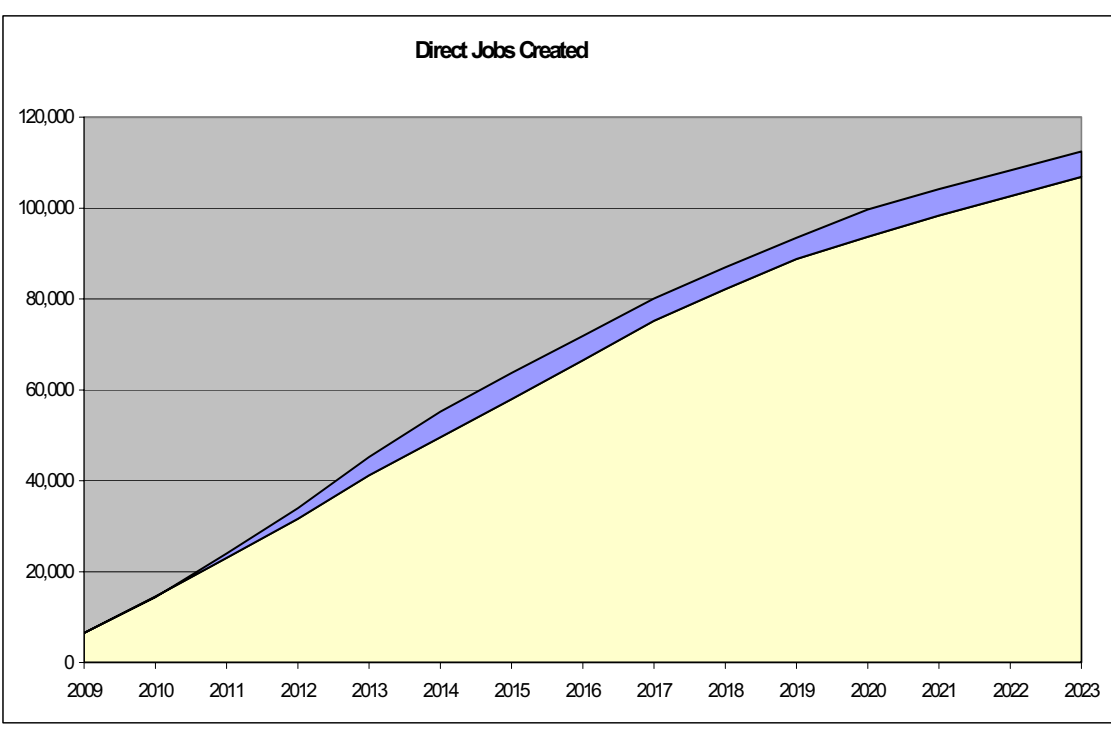

Figure 3. Growth of Direct Jobs over Study Timeframe

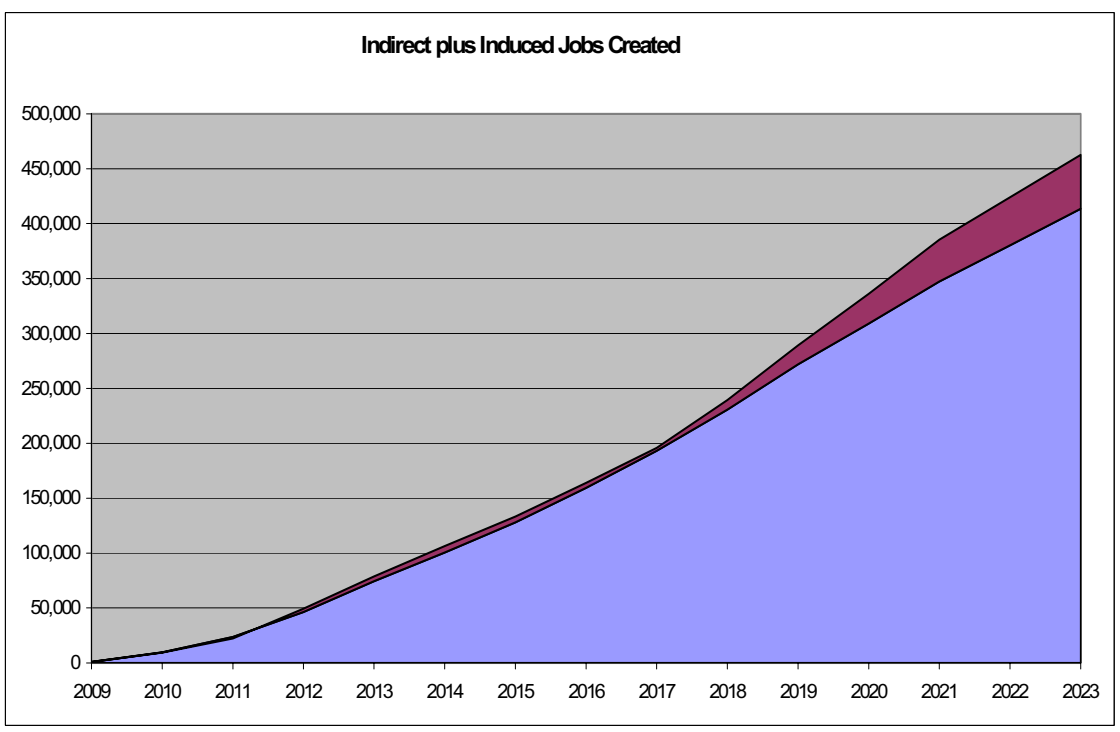

In both Figures 3 and 4, the lower curve represents the cumulative number of jobs added due to the lower estimate of 33 plants of 1500 MWe each. The small wedge above the basic curve represents the additional jobs from deploying the higher number, 41 units, of 1200-megawatt capacity each.

Figure 3 combines the construction, manufacturing, and operations into the 'Direct Jobs' category.

Figure 4 adds the Indirect and Induced Jobs together.

These figures clearly show the approximately 4 to 1 ratio of Indirect (plus Induced) to Direct Jobs. 
Figure 4. Growth of Indirect plus Induced Jobs over Study Timeframe

Bechtel Power's survey of suppliers was conducted via structured phone calls to the suppliers of interest. Many of these companies commented on the general disbelief that nuclear power would return to the United States in sufficient quantities to make it economically feasible. Clearly, a strong commitment by the Federal Government is needed for most of the jobs discussed in this report to be realized.

\subsection{Direct Job Comparison}

Figures 5 and 6 compare the construction, manufacturing, and operations jobs directly created through new nuclear power plants orders. Figure 5 is based on a lower number (33) of higher-capacity (1500MWe), single-unit plants while Figure 6 is based on 41 1200-MWe plants.

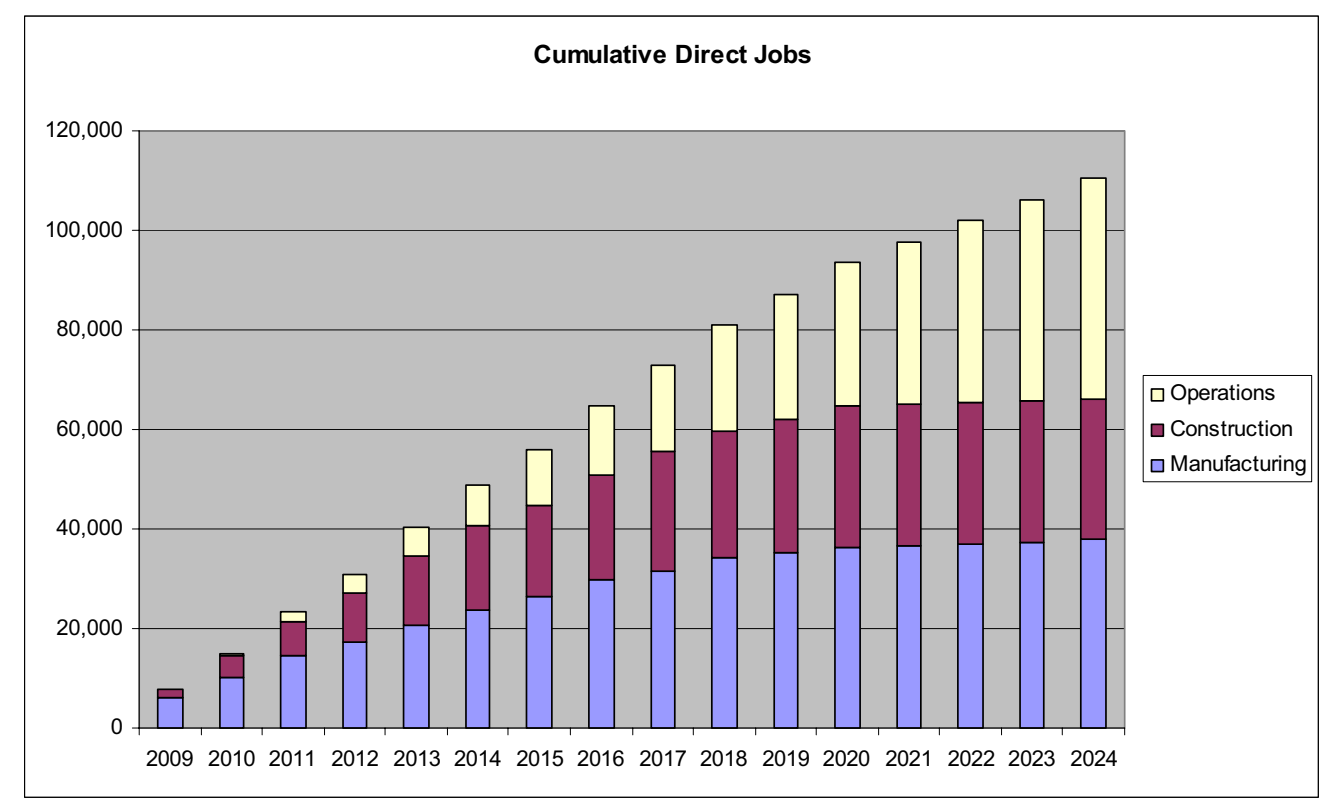

Figure 5. Direct Jobs Due to 33 1500-MWe Units over 15 Years 


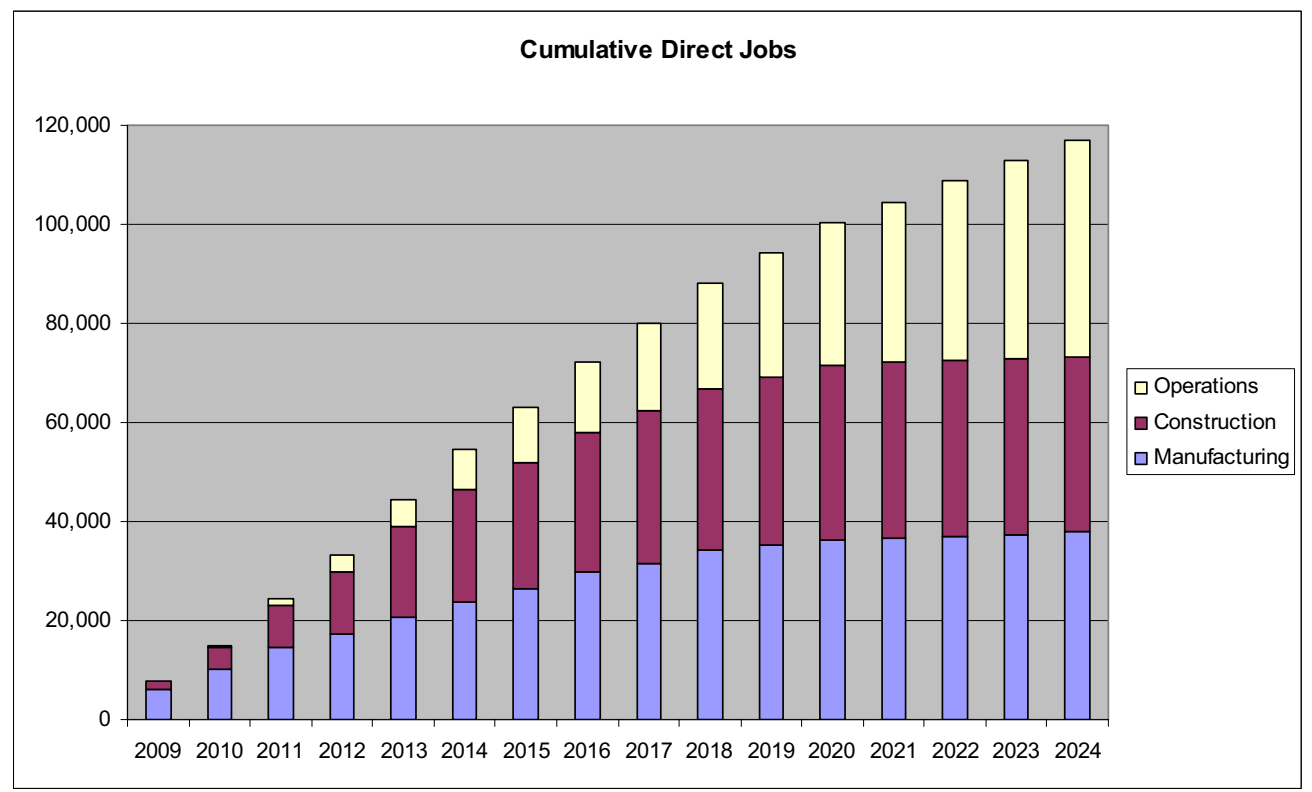

Figure 6. Direct Jobs Due To 41 1200-MWe Plants Over 15 Years

\subsection{Direct, Indirect, and Induced Job Comparison}

Figures 7 and 8 compare the Direct Jobs (from Figures 5 and 6) with the Indirect and Induced nonnuclear jobs. Once again, Figure 7 represents 33 1500-megawatt units while Figure 8 represents 411200 MWe units.

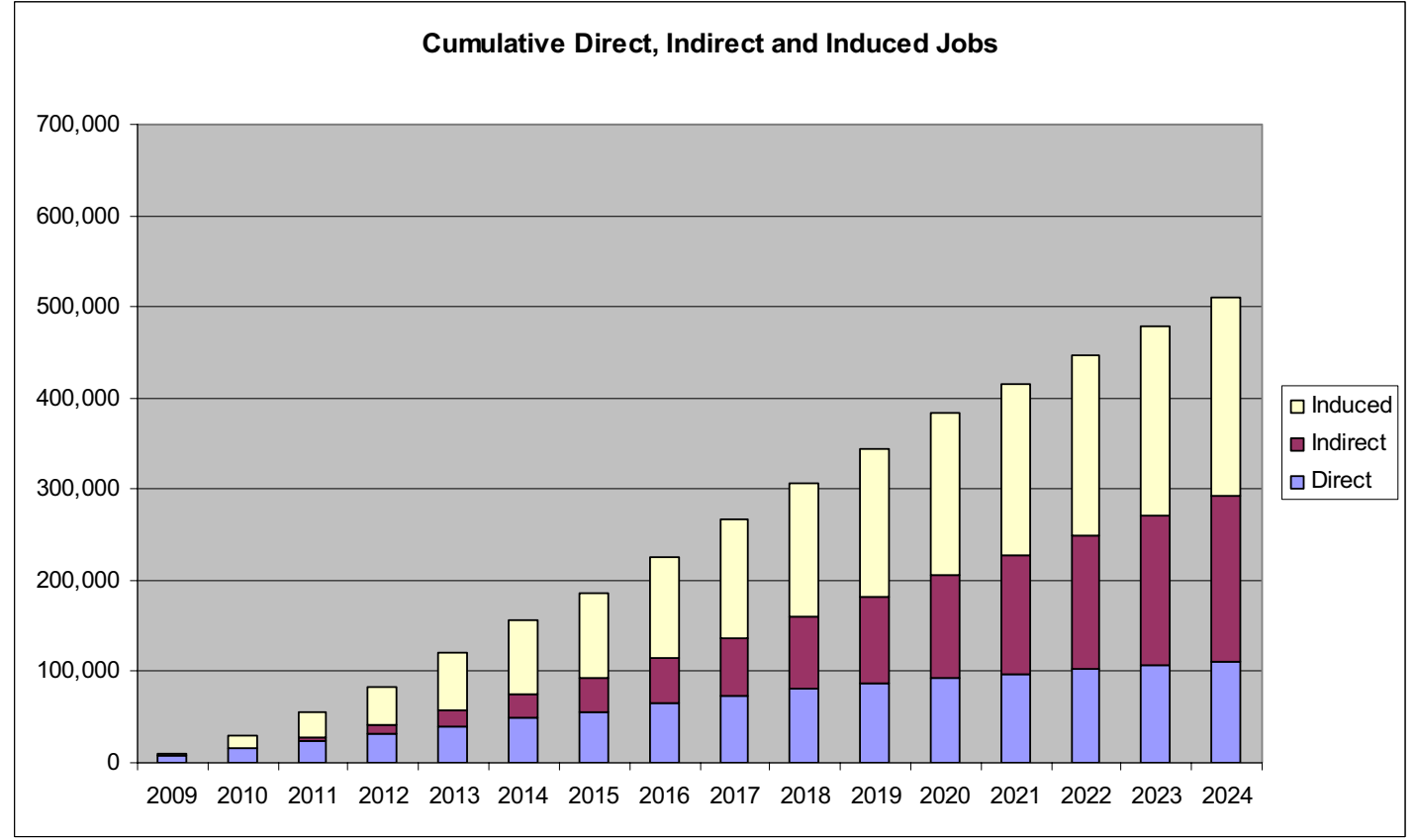

Figure 7. Direct vs. Indirect vs. Induced Jobs by Year for 1500MWe Units 
U.S. Job Creation Due to Nuclear Resurgence in the United States

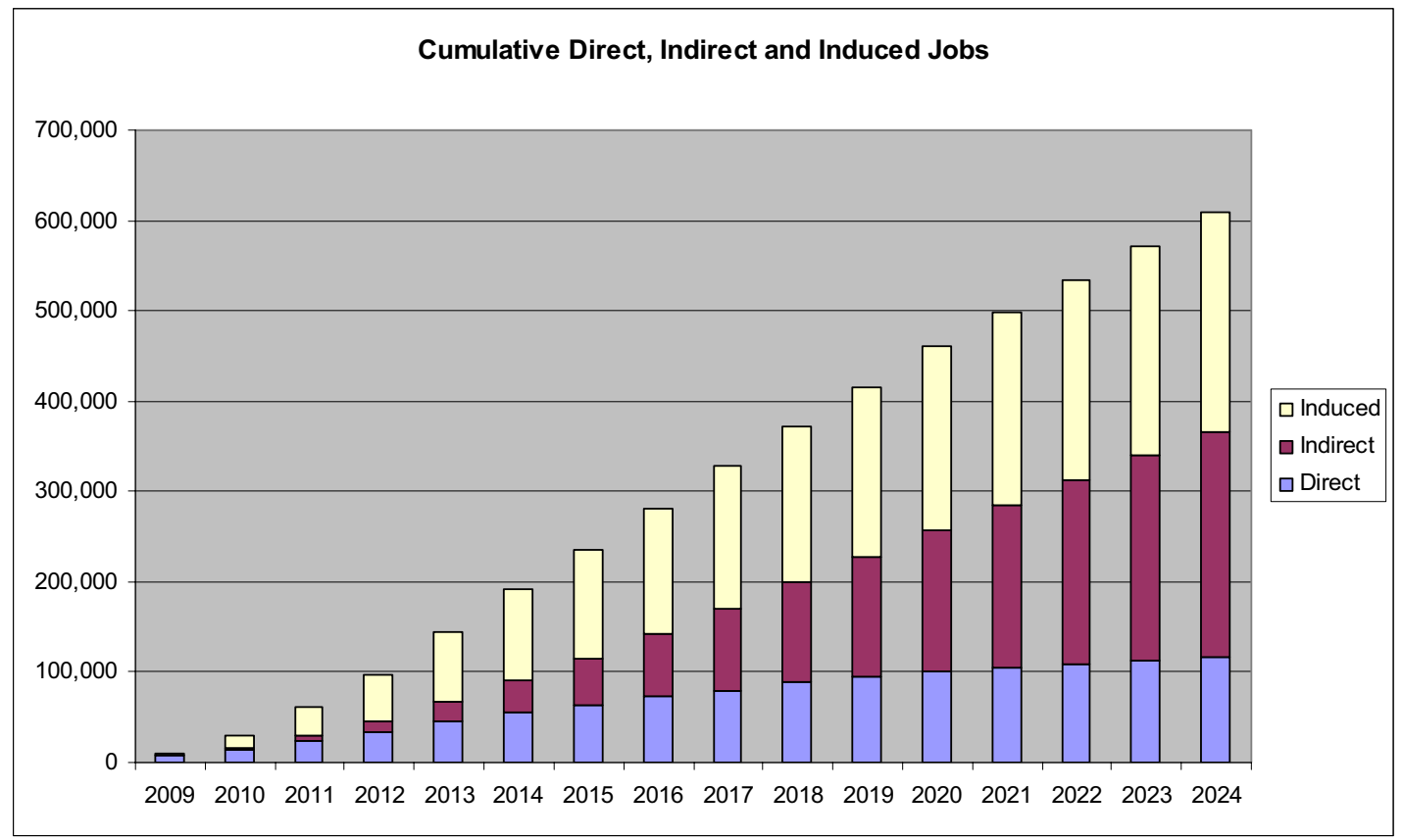

Figure 8. Direct vs. Indirect vs. Induced Jobs by Year for 1200-MWe Units 
The ripple-down effect leading to the creation of indirect and induced jobs quickly surpasses the number of repatriated manufacturing jobs. While a portion of the Induced Jobs are lower-wage service industry positions, the majority of these new U.S. jobs employ trained and educated personnel earning a family wage.

\section{COMPARISON OF COAL VERSUS NUCLEAR JOBS}

On October 12, 2004, a study status presentation was made to the SEAB Task Group indicating that there would be 117,000 additional direct jobs added to the domestic economy as a result of new nuclear plants deployed in the U.S. through 2024. During their discussion, the Task Group posed the following question:

How does this compare to the number of jobs created if the same MWe were generated using coal technology?

The baseline scenario for comparing coal versus nuclear jobs follows the Vision 2020 proposal of $50,000 \mathrm{MWe}$ of new electrical generating capacity. Rather than abruptly stopping new plant orders once the 50,000 MWe is met, the model assumes new plants continue to be ordered beyond 2020. These additional orders increased the jobs created in all job categories.

Data was generated for this scenario using the Westinghouse 1150-MWe AP1000 nuclear plant design. To determine the difference in job creation between coal and nuclear plant, the AP1000 plants were compared to 1500-MWe coal plants that employ two 750-MWe conventional pulverized coal-fired generators, used by Peabody Energy and other owner-operators. The coal plants were deployed to maintain the same total electrical generating capacity as the 1150-MWe nuclear plants. The coal plants, however, were modeled as needing only 3 years to construct instead of the 5 years for nuclear plants.

Additionally, no new manufacturing jobs were modeled for the coal plants. Discussions with industry experts suggested that the coal plant equipment manufacturers are still strong in the U.S. and will utilize excess capacity to fill most—if not all—of the new equipment demand.

Results of the analysis are displayed in Table 3. From the results of this analysis, the job creation potential for nuclear power plants is clearly greater than that for coal plants. The jobs reported in this section, however, have slightly different results from previous sections, which present results of the initial modeling effort that provided a parametric analysis of nuclear plants with capacities ranging from 1200 to $1500 \mathrm{MWe}$.

Table 3. Job Comparison Between Nuclear and Coal

\begin{tabular}{|c|c|c|}
\hline Life-Cycle Stage & $\begin{array}{c}\text { Nuclear } \\
\text { AP 1000 }\end{array}$ & $\begin{array}{c}\text { Coal } \\
\text { Pulverized Coal-Fired } \\
\text { Generators }\end{array}$ \\
\hline Construction Jobs & 35,000 & 25,600 \\
\hline Operator Jobs & 45,600 & 7,800 \\
\hline Manufacturing Jobs & 38,000 & 0 \\
\hline Indirect/Induced Jobs & 530,000 & 175,000 \\
\hline Total Jobs & $\mathbf{6 4 8 , 6 0 0}$ & $\mathbf{2 0 7 , 8 0 0}$ \\
\hline
\end{tabular}




\section{EXPANDED STUDY TOPIC AREAS}

The question this study has tried to answer is complex and dependent upon many factors. As answers were found, they often led to more questions. The following study areas are suggested for follow-on investigation to help refine, expand, and validate the information provided in this initial report.

Additional Economic Benefits. This initial study looked at the potential for the creation of jobs in the United States given resurgence in the nuclear power industry. However, more than just jobs will be impacted by such a decision. Location of plants, other related industry impacts, diversity of energy supply, and other types of benefits will also be accrued with the deployment of new nuclear generating capacity. Looking into the additional benefits can help develop strategies to facilitate such deployment.

Favorable Factors. This study assumes that new Generation III/III+ plants would be used to generate 50,000 MWe of new electrical power by 2020 . However, many factors will influence the decision to deploy new plants. While many suppliers replied that they were capable of responding to a new rollout, they also cited the need for a solid commitment and deployment schedule. Financial incentives, Government-Industry partnerships, new permitting and licensing processes, liability issues, etc. will all play a factor in determining if, when, where, how, and which new nuclear power plants are built in the United States. Further analysis of these dynamic and interrelated issues may provide additional insight that facilitates job growth and repatriation.

Second Tier Suppliers. Bechtel Power Corporation noted in their survey that the first-tier suppliers were concerned that their suppliers might not have sufficient capability to support a revitalization of the nuclear industry. In particular, these first-tier suppliers expressed concern regarding raw material supply and foundry and pipe mill capabilities. By continuing the Bechtel survey to include second and third-tier suppliers, additional avenues of job repatriation and growth can be identified and additional barriers or opportunities can be uncovered. More detail on this issue can be found in the Study of the Impact on Domestic Manufacturing and Supply Infrastructure Resulting from New Nuclear Plant Deployment contained in Appendix A of Volume 2.

The Global Perspective. Reflecting on the few large component suppliers discussed above also leads to a natural follow-on of looking at the global nuclear power industry. While the surveyed companies are supportive of a resurgence of nuclear power in the United States, is the industry as a whole capable of supplying the goods and materials needed on a global scale? Is the timing of Vision 2020 such that the global industry is swamped with new orders? What are the projected power needs across the globe, and how much demand is required to be filled by nuclear sources? The answers to these and other similar questions may impact U.S. decisions regarding nuclear energy.

Fossil vs. Nuclear. This study has provided preliminary answers to the questions, "What if 50,000 MWe were supplied by new fossil plants instead of nuclear?" and "What types and numbers of jobs are provided by deploying the nuclear plants compared to fossil plant deployment?". A more thorough analysis is necessary for the relative merits of nuclear power (when compared to coal and/or gas power) to be determined.

Complete Plant and Life Cycle Coverage. Relatively few large component suppliers exist today. Consequently, those suppliers chose to provide limited feedback in the Bechtel survey out of concern that strategic plans could be inferred from the results, thus giving their competitors a potential advantage. Historical data, however, could be used to derive employment needs for these large components. By adding this capability to the analysis, a more accurate picture of domestic job creation would be available. In addition, looking at the full life cycle of the plants and estimating the upstream 
(i.e., design and licensing) and downstream (i.e., decontamination and waste management) jobs would further enhance the analyses and provide even greater refinement of the reported numbers.

Trade Association Involvement. The Bechtel supplier survey yielded results from over 40 companies. Mathematical curve fitting was used to take these disparate data points from the surveys and create a representation of the entire field of companies. Through industry trade association involvement, actual data could be obtained to take the place of statistical approximations and, with all interested parties providing input; current data gaps could be more easily filled. Additionally, the modeling technique used in this study is a powerful tool for exploring and defining dynamic and chaotic relationships surrounding an issue. Workshops with the trade associations, union organizations, technology providers, educational institutions, and others could more quickly provide the information needed in modeling these complex and interrelated relationships. These workshops can also help to build strong partnerships and a growing industry consensus on the matters of nuclear energy. This represents a more proactive use for modeling and decision analysis tools along the lines of the successful Decision Makers Forums sponsored by Senator Domenici. 


\section{U.S. Job Creation Due to Nuclear Power Resurgence in The United States - Volume 2}

\section{Appendices}

November 2004

Idaho National Engineering and Environmental Laboratory Bechtel BWXT Idaho, LLC 
INEEL/EXT-04-02384

Volume 2

\section{U.S. Job Creation Due to Nuclear Power Resurgence in the United States - Volume 2}

\section{Appendices}

\begin{tabular}{ll} 
INEEL & Bechtel Power Corp. \\
\hline C.R. Kenley* & R.L. Baker \\
R.D. Klingler & S.A. Close \\
C.M. Plowman & V.L. McDonnell \\
R. Soto & S.W. Paul \\
R.J. Turk & L.R. Rabideau \\
& S.S. Rao \\
& B.P. Reilly
\end{tabular}

November 2004

Idaho National Engineering and Environmental Laboratory Idaho Falls, Idaho 83415

Bechtel Power Corporation

Frederick, Maryland 21703

Prepared for the

U.S. Department of Energy

Office Nuclear Energy, Science, and Technology

Under DOE Idaho Operations Office

Contract DE-AC07-99ID13727 



\section{Appendix A}




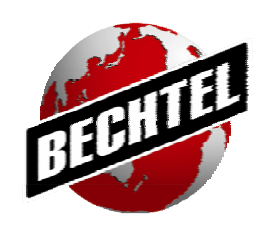

Study of the Impact on Domestic Manufacturing and Supply Infrastructure Resulting from New Nuclear Plant Deployment

\author{
Prepared by: \\ Bechtel Power Corporation \\ Frederick, Maryland
}

\begin{abstract}
Prepared For:
Idaho National Engineering and Environmental Laboratory

and

U.S. Department of Energy
\end{abstract}

Revision 0 - For Use

September 29, 2004 


\section{Table of Contents}

Executive Summary

Introduction, Purpose, and Basis

Summary of Results

Potential Second-Phase Focus Areas

Construction Jobs

Commodity Reports (Manufacturing Jobs)

Cable

Concrete, Cement, and Reinforcing Steel

Compressors/Vacuum Pumps

Condenser

Control Valves

Cranes

Dampers/Louvers

Diesel Generators

Fans

Heat Exchangers

Load Centers (480 V), MCC Sets, and Switchgear

Pipe

Prefabricated Equipment Modules

Pumps (Small/Large)

Reactor Vessels and Large Components

Structural Steel

Tanks (Field Fabricated)

Tanks (Shop Fabricated)

Turbine/Generator Sets

Valves

Water Treatment Plants

Fabricated Parts and Components

Appendix A-Summary of Number of Surveyed Companies by Commodity

Appendix B-Blank Survey Package with Cover Letter 


\section{Executive Summary}

The purpose of this study was to determine the potential impact on the number of manufacturing jobs in the U.S. resulting from the construction of a new generation of nuclear reactors in the U.S. In addition to the growth in the manufacturing sector, an estimate into the potential job growth in the construction trades was also undertaken.

The basic assumption proposed to the manufacturers was the national need for 355,000 megawatts of new and replacement electrical generation within the next two decades. Of that total capacity, it was assumed that 50,000 megawatts of new nuclear electric generating capacity would be added to the national grid by 2020 by constructing as few as 33 new nuclear plants, each with 1,500 MWe capacity, or as many as 41 plants with 1,200 MWe capacity. The first plant would be ordered in about 2009.

The challenge for the companies surveyed was to project (over time) the U.S. jobs that would be created to support the manufacture of equipment and/or production of commodities in their respective product sectors. The number of survey participants was limited to major suppliers either currently actively supporting the nuclear industry or who may have a long-term interest in supporting new nuclear power plants in the future.

A total of 57 suppliers were targeted to participate in this survey. Of the targeted population, 40 companies responded. Some equipment/commodity areas forecasted no job growth because the volume of new revenue available for that commodity was not large enough to equate to manufacturing expansion, new facilities, or additional shifts. In other instances, this was because companies would most likely rely on their existing relationship with their offshore suppliers. For some equipment/commodities, such as control valves, the reported job growth was large ranging from none to robust. Robust job growth was forecast by all survey participants for concrete, condensers, cranes, fans, heat exchangers, structural steel, shop fabricated tanks, and fabricated parts and components. Detailed results, by commodity group, are presented in the body of this report.

In addition, during the course of these surveys, multiple suppliers expressed several consistent themes or concerns. They are:

- Industry Commitment

- Foundry Capability

- Pipe Mills Capability

- Raw Material Supply

- Active Industry \& Trade Group Discussions

Construction craft labor growth was also assessed in this study. An evaluation was made of construction staffing requirements considering both past craft labor performance, based on Bechtel's historical involvement in this industry, and the new generation construction environment with improved reactor designs and modular fabrication. The assessment concludes that there would be significant growth in construction craft labor, adding jobs to an already stretched workforce. 
The results of this survey will be used by the Idaho National Engineering and Environmental Laboratory in a study they are preparing entitled "Economic Impact of Nuclear Power Resurgence in the United States". 


\section{$\underline{\text { Introduction, Purpose, and Basis }}$}

This study has been prepared at the request of the Department of Energy (DOE) through a subcontract to Bechtel Power Corp. from the Idaho National Engineering and Environmental Laboratory (INEEL). The purpose of this investigation is to determine the potential impact on the number of manufacturing jobs in the U.S. resulting from the construction of a new generation of nuclear reactors in the U.S.

Blue-collar manufacturing jobs in the U.S. have undergone significant reductions for several recent years because labor costs in other countries are putting pressure on U.S. competitiveness. More recently, white-collar technology jobs have followed suit because offshore-educated labor wages remain lower than wages in the U.S.

At the same time, the U.S. is facing higher energy prices as countries like India and China begin to demand more of the worlds oil production to fuel growing economies. The availability and security of oil imports is fast becoming a national concern leading to the need for energy independence for the U.S. This, in turn, is leading many to consider nuclear power as a viable option.

The rate at which the new generation of nuclear power plants will be constructed in the U.S. is uncertain. According to the Energy Information Administration (EIA), the statistical arm of the DOE, the nation will need 355,000 megawatts of new and replacement electrical generation within the next two decades, assuming electricity demand grows at the modest rate of 1.8 percent per year. Because reliable and affordable electricity is the backbone of the nation's economic and national security, the nuclear energy industry set forth in 2001 a long-term vision of the industry's future. The cornerstone of that vision is adding 50,000 megawatts of new nuclear electric generating capacity to the national grid by 2020 . This national vision is referred to as "Vision 2020"1. This is, in itself, a somewhat conservative assumption in that 50,000 megawatts will not maintain the status quo percentage of power in the U.S. generated by nuclear energy (14 percent verses the current 20 percent).

Several major reactor vendors are actively pursuing U.S. NRC design certification approvals for its advanced reactors. The electrical output of these plants ranges from about 1,200 to 1,500 MWe. This means that to reach the 50,000 megawatt goal of Vision 2020, between 33 and 41 plants would need to be constructed. Based on these assumptions and assuming the first plant is ordered in about 2009, this would require that plants be constructed at the rate shown in Figure 1. The earliest plant could be operating by about 2014. This build-out of nuclear power plants in the U.S. will occur approximately in parallel with a significant planned build-out in China, Korea, and elsewhere overseas.

\footnotetext{
${ }^{1}$ Nuclear Energy and the Nation's Future Prosperity, Nuclear Energy Institute, www.nei.org
} 


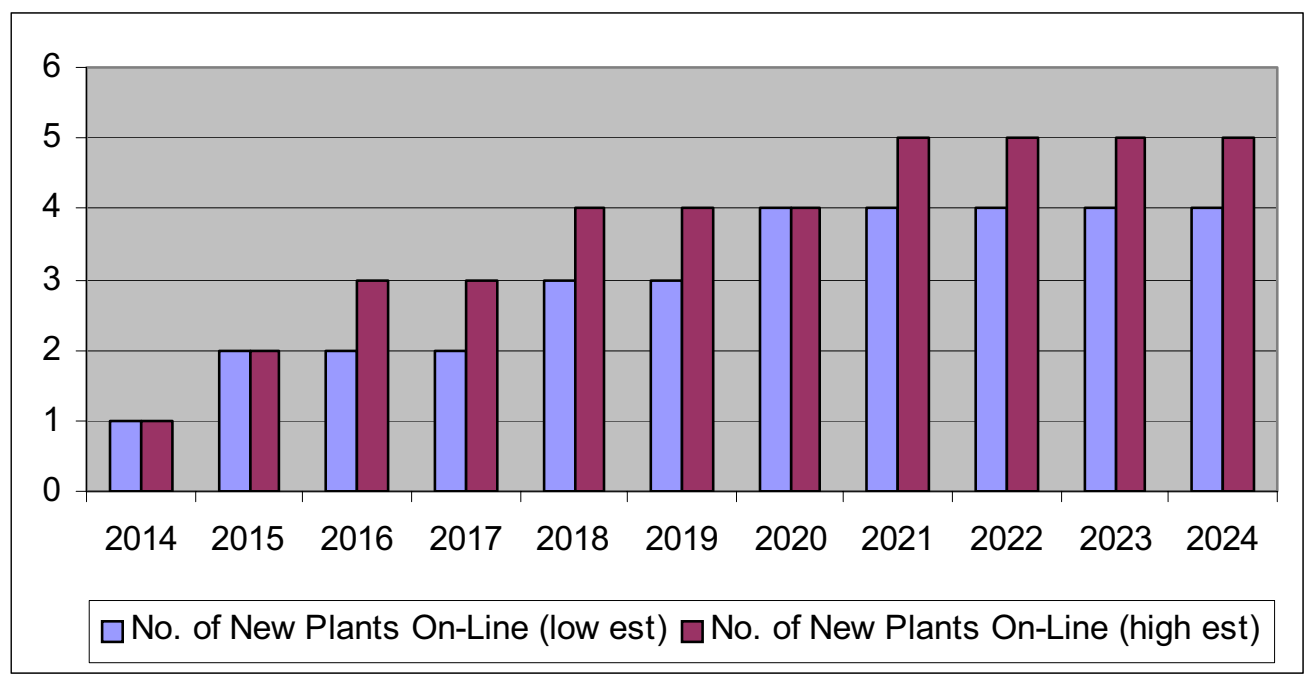

Figure 1: Estimate of New Nuclear Plants Operating, by Year

Depending on the type of reactor chosen, the types and quantities of equipment and bulk commodities to construct the plant will vary. Annex B, Tables 1(a), 1(b), 1(c), 1(d), and 1(e) summarize the approximate ranges of equipment and commodities that would be needed to construct a single hypothetical nuclear power plant. The challenge for the companies surveyed was to project (over time) the U.S. jobs that would be created to support the manufacture of equipment and/or production of commodities in their respective product sectors. Annex B contains the survey questionnaire that was provided to each surveyed company.

To assist suppliers in understanding lead times, Figure 2 illustrates, for a typical single-unit plant, a simplified schedule for permitting, design, construction, and startup of an advanced reactor. This figure was taken from a report prepared for the DOE under Cooperative Agreement DE-FC07-03ID14492 2 .

2 "Study of Construction Technologies and Schedules, O\&M Staffing and Cost, Decommissioning Costs and Funding Requirements for Advanced Reactor Designs," May 27, 2004. 


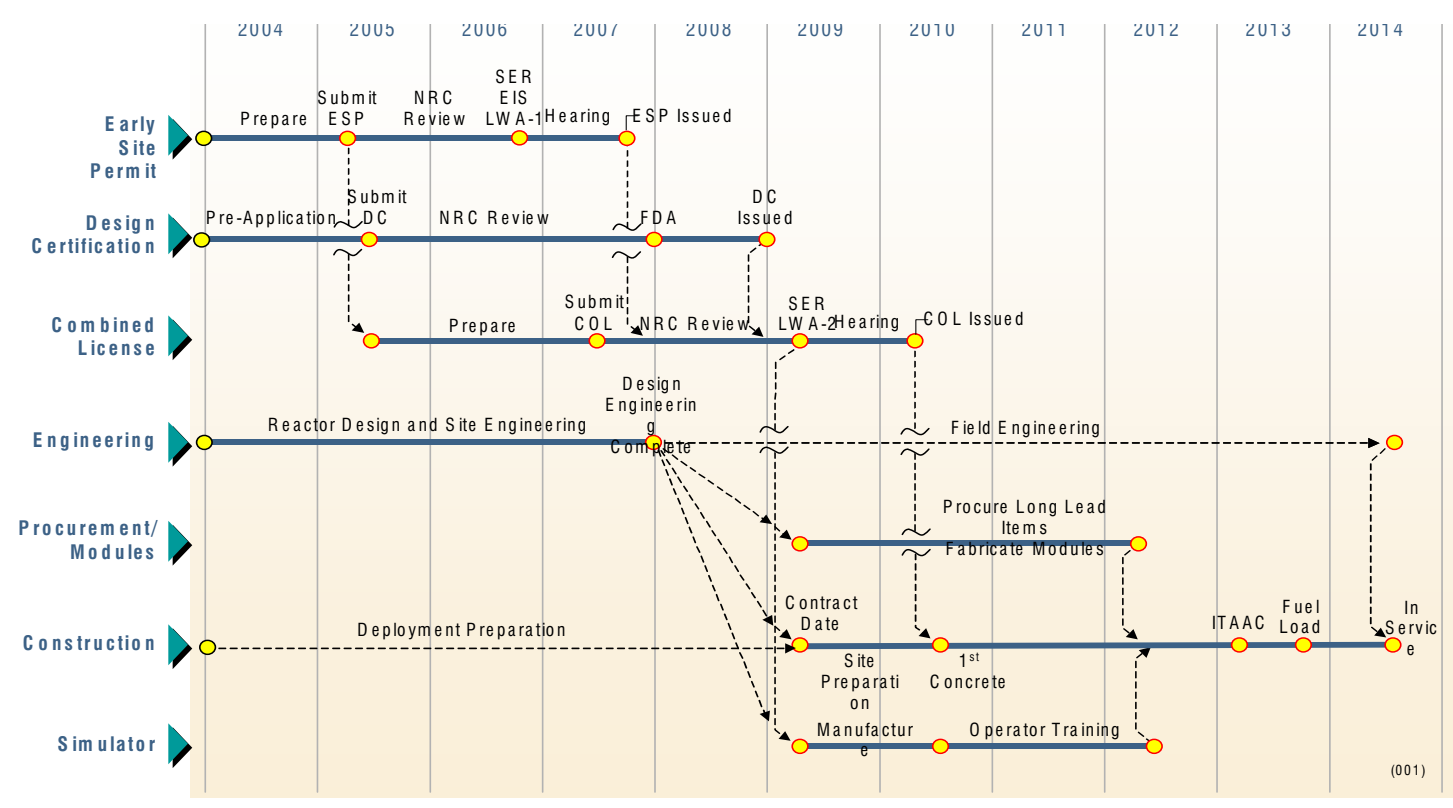

Figure 2: Conceptual First Plant Deployment Schedule 
As can be seen from this schedule, the procurement of long-lead equipment will need to begin about 5 years before plant startup.

The schedule to obtain survey results for the DOE was very aggressive. Therefore, we limited both the number of survey questions and the number of survey participants to major suppliers either currently actively supporting the nuclear industry or who may have a long-term interest in supporting new nuclear power plants. It should be noted that not all power plant commodities are included in this survey. Annex A lists the number of companies that were targeted for the survey and the number that responded. Examples of market sectors that have not been included in the survey are electrical raceway, instrumentation, miscellaneous steel/decking, pipe hangers, fasteners, insulation, HVAC and ductwork, cooling towers, prefabricated buildings, plumbing, chemical systems, and fire protection.

\section{Summary of Results}

A total of 57 suppliers were targeted to participate in this survey. Of the targeted population, 40 companies responded. In the case of 4 equipment/commodity categories there were no survey responses. The surveys were usually conducted by telephone with 2 Bechtel representatives to record the responses. Table 1 summarizes the results for the companies surveyed.

Table 1 - Summary of Results

\begin{tabular}{|l|c|c|}
\hline \multicolumn{1}{|c|}{$\begin{array}{c}\text { Equipment/ } \\
\text { Commodity }\end{array}$} & $\begin{array}{c}\text { Number of } \\
\text { Respondents }\end{array}$ & $\begin{array}{c}\text { Forecast Job Growth } \\
\text { (None/Modest/Moderate/Robust) }\end{array}$ \\
\hline Cable & 0 & No reports \\
\hline Concrete & 2 & Robust \\
\hline $\begin{array}{l}\text { Compressors/Vacuum } \\
\text { Pumps }\end{array}$ & 0 & Robust \\
\hline Condensers (Main) & 1 & None to robust \\
\hline Control Valves & 2 & Robust \\
\hline Cranes & 2 & None to robust \\
\hline Dampers/Louvers & 0 & Robust \\
\hline Diesel Generators & 2 & Robust \\
\hline Fans & 1 & None \\
\hline Heat Exchangers & 2 & Modest to robust \\
\hline $\begin{array}{l}\text { Load centers, MCCs, } \\
\text { switchgear }\end{array}$ & 2 & Modest to robust \\
\hline Pipe & 2 & None to modest \\
\hline $\begin{array}{l}\text { Prefabricated Equipment } \\
\text { modules }\end{array}$ & 1 & Robust \\
\hline Pumps, Large and Small & 4 & Robust \\
\hline $\begin{array}{l}\text { Reactor Vessels and Large } \\
\text { Components }\end{array}$ & 3 & \\
\hline Structural Steel & 2 & \\
\hline Tanks (shop fabricated) & 2 & \\
\hline
\end{tabular}




\begin{tabular}{|l|c|c|}
\hline \multicolumn{1}{|c|}{$\begin{array}{c}\text { Equipment/ } \\
\text { Commodity }\end{array}$} & $\begin{array}{c}\text { Number of } \\
\text { Respondents }\end{array}$ & $\begin{array}{c}\text { Forecast Job Growth } \\
\text { (None/Modest/Moderate/Robust) }\end{array}$ \\
\hline Tanks (field erected) & 1 & None \\
\hline Turbine /Generator Sets & 3 & None to modest \\
\hline Valves & 4 & No reports \\
\hline Water Treatment plants & 0 & Robust \\
\hline $\begin{array}{l}\text { Fabricated Parts and } \\
\text { Components }\end{array}$ & 1 & \\
\hline
\end{tabular}

In Table 1 the of forecast job growth category definitions are:

$$
\begin{gathered}
\text { None }-0 \text { growth forecast } \\
\text { Modest - greater than } 0 \text { and less than } 10 \% \\
\text { Moderate - greater than } 10 \% \text { and less than } 25 \% \\
\text { Robust - greater than } 25 \%
\end{gathered}
$$

As can be seen from this summary, some equipment/commodity areas forecasted no job growth. In some instances, this was reported because the volume of new revenue available for that commodity was not large enough to equate to manufacturing expansion, new facilities, or additional shifts. In other instances, no growth was forecast because companies would most likely rely on their relationship with their offshore suppliers. They reported that the offshore relationships have been developed over the past 2 to 3 decades, when U.S. commercial business declined and they needed suppliers for their offshore nuclear power projects.

For some equipment/commodities, such as control valves, the reported job growth ranged from none to robust.

Robust job growth was forecast by all survey participants for concrete, condensers, cranes, fans, heat exchangers, structural steel, shop fabricated tanks, and fabricated parts and components. In 3 of these 8 instances only one company participated in the survey.

Details for each commodity is reported in the "Commodity Reports (Manufacturing Jobs)" section of this report.

\section{Potential Phase 2 Focus Areas}

During the course of these surveys, multiple suppliers expressed several consistent themes or concerns. They are summarized in this section with recommendations for areas of further investigation during a Phase 2 follow-on study.

Industry Commitment: Several major suppliers (large multinational companies) expressed concern over the leadership and commitment provided by the industry, owners, and government to proceed with nuclear power plant development in the U.S. It would appear that these suppliers are ready and capable of responding to a new rollout, but in order to commit any resources, they are looking for a solid commitment over a defined schedule for the new facilities. 
How to provide the industry with this type of leadership is an area that can be investigated further.

Foundries: Several survey participants indicated a strong concern that the U.S. foundry capabilities have atrophied to the extent that they will be a constraint to the supply chain for nuclear manufacturers. This theme was commonplace in the survey responses from valve and pump companies. Phase 2 would examine the condition of the foundry capability in the U.S. What capacity and technology enhancements would be needed to supply the downstream manufacturers? What capacity and technology enhancements would be needed to be competitive with overseas foundries? What investments would be needed? What investment would be necessary to expand foundry capacity? What would be the U.S. job growth potential for the U.S. foundries?

Pipe Mills: Several survey participants indicated a concern that the U.S. pipe mill capacity has atrophied to the extent that this would be a constraint to the supply chain for nuclear manufacturers. Phase 2 would examine the condition of the pipe mill capability in the U.S. What capacity and technology enhancements would be needed to supply the downstream manufacturers? What capacity and technology enhancements would be needed to be competitive with overseas pipe mills? What investments would be needed? What investments would be necessary to expand capacity? What would be the U.S. job growth potential for the U.S. pipe mills?

Raw Material Supply: A few survey participants indicated that raw materials (copper and steel) would be a constraint to nuclear build-out. Phase 2 would investigate this condition report on capacity and technology enhancements that would build these supply chain elements up to the extent necessary to support new plant build-out.

Job Growth in Other Sectors: Phase 2 would look in some depth at job growth in sectors other than manufacturing, determine job growth estimates, and identify job growth constraints and issues. Sectors would include education, plant operations, architect-engineering services, plant security, and others, which are categorized in the macroeconomic models as indirect jobs.

Industry Workshops: Most survey participants indicated that although they are members of multiple trade associations, the topic of an impending business ramp-up to support the nuclear industry is not a "hot" topic. Phase 2 could include organizing and holding industry workshops (under DOE sponsorship) to discuss manufacturing concerns and industry issues associated with new nuclear power plant (NPP) build-out. Invited participants would include those companies that participated in this survey, subsuppliers such as foundries and pipe mill companies, etc.

\section{Construction Jobs:}

Bechtel has attempted to forecast the growth in construction craft labor due to the renewal of the nuclear power industry within the U.S. We have provided results in a similar format of the potential job growth as we requested in our surveys of component manufacturers. The result of our assessment follows. 
Projected Job Growth:

The following job growth estimate for site craft labor has been developed based on historical data from more than 20 Units commissioned after 1975 or with capacities greater than 1,000 MWe (BWRs \& PWRs). The staffing projections have been reduced by $25 \%$ (order of magnitude estimate) compared to historical construction staffing to account for simplified advanced reactor designs and current reactor vendor plans for significant modularization of the plants. Compared to historical nuclear plant construction, modularization will result in a shift of craft jobs from the job sites to manufacturing facilities where large, preassembled modules will be constructed.

\begin{tabular}{|c|c|c|c|c|c|c|c|c|c|c|c|c|c|c|}
\hline Category & '09 & '10 & '11 & '12 & '13 & '14 & '15 & '16 & '17 & '18 & '19 & '20 & 21 & '22 \\
\hline $\begin{array}{l}\text { Construction } \\
\text { Trades (x1000) }\end{array}$ & 1.5 & 5.5 & 12 & 19 & 25 & 29 & 33 & 36 & 39 & 41 & 42 & 36 & 24 & 11 \\
\hline \multicolumn{15}{|l|}{ Engineering } \\
\hline \multicolumn{15}{|l|}{$\mathrm{QA} / \mathrm{QC}$} \\
\hline $\begin{array}{l}\text { Shipping and } \\
\text { Receiving }\end{array}$ & N/A & N/A & N/A & N/A & N/A & N/A & N/A & N/A & N/A & N/A & N/A & $\mathrm{N} / \mathrm{A}$ & N/A & $\mathrm{N} / \mathrm{A}$ \\
\hline \multicolumn{15}{|l|}{$\begin{array}{l}\text { Field support (SU, } \\
\text { service, training, } \\
\text { warranty, etc.) }\end{array}$} \\
\hline Others, define & & & & & & & & & & & & & & \\
\hline
\end{tabular}

Job growth for engineering, QA/QC, field support, etc. has not been evaluated as part of this study. Construction Trade projections exclude NSSS work. Historically this has been included with the Reactor Supplier's scope.

Quality Program:

Many construction companies involved in nuclear plant work have maintained a QA program in accordance with 10CFR50 Appendix B or NQA-1 to support the nuclear industry.

\section{Threshold for additional Expansion and Lead Time:}

The ramp-up for the construction staff to support new nuclear plants would begin about 5 years prior to the start-up date for the new unit. Thus for the first unit to be operating by 2014, the ramp-up for the construction staff would begin in 2009. For the purpose of this survey it is assumed that the ramp-up rate for each new unit is about 100 per month and would peak at about 2,500 craft workers. Assuming the plant build-out rate assumed by the survey, the craft labor demand would peak at about 42,000 workers in 2019.

\section{$\underline{\text { Incentives and Constraints: }}$}

The ability of the construction industry to support the build-out of new nuclear plants assumed by his survey will be challenging. The industry will need to prepare for the build-out by instituting craft training to assure the skill sets are available for the work. Recent construction 
experience in the US indicates that incentives will most likely be required to attract and maintain a large work force to the job site.

\section{Other Issues:}

Nation trade associations and unions have not focused on the challenges posed by the potential for new nuclear build-out as mentioned above.

\section{Summary and Indicators:}

Based on the magnitude of the job growth projections, craft staffing studies should be conducted. The impact of modularization on the required jobsite staffing levels needs further study.

\section{Special Issues:}

The construction of new generation nuclear plants presents several issues and challenges concerning the next generation of craft workers that will be available to support the build-out of this industry. Based on the Nuclear Energy Institute's Vision 2020, up to 41 plants $(50,000$ $\mathrm{MWe}$ ) would need to be constructed starting in 2009. In order to achieve this goal in 11 years, an average of $3+$ plants would have to be under construction each year. To support this goal, craft staffing would need to peak at $42,000+$ in 2019.

As a stand-alone figure, the peak craft requirement is significant but achievable. However, what is unknown is the demand for craft labor that may come from other industry sectors such as fossil power, local/regional/national infrastructure projects, government facilities, etc, during the same timeframe.

The design of new generation plants is intended to be simpler with faster construction schedules (4-6 years from contract award to commercial operation) that utilize a significant amount of preassembled and modularized components. The profile of the construction worker needed to build these new generation plants is young, mobile, and trained to work with new technology. In 2004, the stark reality is that today's construction worker, with an average age of 45-50, will be leaving the industry as the build-out gets underway and the next generation needed to support the peak requirement is not in the workforce yet.

While the issues and challenges facing craft staffing are formidable, the critical issues that need to be addressed are summarized below. Implementation of specific action plans to address these issues would follow during the 5-year lead-time before construction activity begins (site preparation in 2009). At this time, no discussions have occurred at the national level between the major Contractor Associations and the International Unions on this potential new work opportunity.

- Assessment of the craft skill requirements needed to work on the new generation nuclear plants. This is a critical, first step to get all the parties together who have a stake in the design/build of these plants. The DOE, Design Engineering Firms, Contractors, Major Equipment Manufacturers, and International Union Presidents and 
their Training Coordinators should form a partnership to assess the craft demand and supply over the next 15 years, identify the skills criteria for training and certifying craftsmen to work on new generation plants, and develop joint recruiting and training strategies. This step represents an important, ongoing communication and industry promotion initiative. This partnership should maintain high visibility and direct oversight for all activities associated with the staffing and execution of these projects.

- Development of National Recruiting and Training Programs. This is a nationwide initiative that identifies the target groups, organizations, government agencies, and union training facilities that can sponsor and assist in the recruitment and training of craftsmen, i.e., National Building Trades Joint Apprenticeship Committees; "Helmets to Hardhats " the military transition program between the armed services and the National Building Trades to transition military personnel to civilian jobs in the construction industry; the North American Contractors Association and National Erectors Association; the Department of Labor and the Immigration and Naturalization Service to assist with local/regional/national recruiting and training programs and $\mathrm{H} 2 \mathrm{~B}$ Visas for foreign workers. Targeted training curriculums would need to be developed that focus on special skills training in rigging, welding, scaffold erection, electrical, instrumentation, and operation of special cranes and construction equipment.

- Negotiation of a National Nuclear Labor Agreement. During the 1970's-1980's, a "Nuclear Stabilization Labor Agreement" was negotiated and utilized on selective nuclear projects. Negotiation and administration of a national labor agreement for new generation nuclear projects would include senior officers from the major Contractor companies and the International Unions who would maintain direct involvement in the proper administration of this national labor agreement. Key provisions in the agreement would address recruiting and retention issues such as housing, per diem and other incentive allowances; employment clearances utilizing the National Building Trades "Smart Card" program which captures information on employment histories, training certifications, personal data, etc., embedded in a credit card; leadership training for Foreman and General Foreman; elimination of restrictions on material purchases and offsite fabrication; flexibility in craft jurisdiction, etc. 
Commodity Reports (Manufacturing Jobs)

A-14 


\section{Cable}

No supplier feedback for this commodity. 


\section{Concrete, Cement, and Reinforcing Steel}

\section{Approach:}

Concrete in the volumes required for projects of the magnitude included in the study phase is typically batched on site. The approach taken with respect to the supply of concrete was to assess the manufacturing implication associated with the supply of cement and reinforcing steel for concrete as key indicators. The potential impacts related to the supply of cement was obtained through correspondence with the Portland Cement Association (PCA), and potential impacts on the supply of reinforcing steel was obtained by interviewing two reinforcing steel fabricators with past and ongoing nuclear experience.

\section{Survey Results-Company A}

Current Employment:

Current employment level of the company's manufacturing business. Also, the number of jobs located domestically and outside the U.S. and the percentage of employees who have current or past nuclear experience.

\begin{tabular}{|l|c|c|c|}
\hline \multicolumn{1}{|c|}{ Category } & $\begin{array}{c}\text { Current } \\
\text { Employee } \\
\text { Level in U.S. }\end{array}$ & $\begin{array}{c}\text { Number } \\
\text { Outside the } \\
\text { U.S. }\end{array}$ & $\begin{array}{c}\text { \% With } \\
\text { Nuclear } \\
\text { Experience }\end{array}$ \\
\hline Manufacturing Trades & 5 & 0 & 100 \\
\hline Engineering & 1 & 0 & 100 \\
\hline QA/QC & 3 & 0 & 100 \\
\hline Shipping and Receiving & 1 & 0 & 100 \\
\hline $\begin{array}{l}\text { Field Support (startup, service, training, } \\
\text { warranty, etc.) }\end{array}$ & 1 & 0 & 100 \\
\hline Others, define & 2 & 0 & 100 \\
\hline
\end{tabular}

Output, Capacity, and Market Share:

Manufacturing output (e.g., number of units produced annually) at the current employment level and shop load percentage at this production rate. This company's domestic market share and current overseas market share. This company's yearly sales volume and the percentage of this sales volume related to domestic/U.S. production.

$$
\begin{aligned}
& \text { Total }=\$ 1.5 \mathrm{M} / \text { year, all domestic } \\
& 40 \% \text { capacity }(4,000 \text { tons/year }) \\
& <1 \% \text { domestic market share } \\
& 4 \% \text { regional market share } \\
& 0 \% \text { overseas market share }
\end{aligned}
$$

\section{Projected Job Growth:}

Considering the company's expected market share, the following table shows the number of additional U.S. jobs created as a result of the projected industry growth to support new nuclear plants. 


\begin{tabular}{|c|c|c|c|c|c|c|c|c|c|c|c|c|c|c|}
\hline Category & 69 & 10 & ‘11 & '12 & '13 & '14 & ‘ 15 & ‘6 & ‘17 & '18 & ‘19 & 20 & 21 & '22 \\
\hline Manufacturing Trades & 4 & 8 & 12 & 12 & 16 & 20 & 0 & 0 & 0 & 0 & 0 & 0 & 0 & 0 \\
\hline Engineering & 2 & 4 & 6 & 6 & 8 & 10 & 0 & 0 & 0 & 0 & 0 & 0 & 0 & 0 \\
\hline $\mathrm{QA} / \mathrm{QC}$ & 2 & 4 & 6 & 6 & 8 & 10 & 0 & 0 & 0 & 0 & 0 & 0 & 0 & 0 \\
\hline Shipping and Receiving & 2 & 4 & 6 & 6 & 8 & 10 & 0 & 0 & 0 & 0 & 0 & 0 & 0 & 0 \\
\hline $\begin{array}{l}\text { Field Support (SU, service, } \\
\text { training, warranty, etc.) }\end{array}$ & 2 & 4 & 6 & 6 & 8 & 10 & 0 & 0 & 0 & 0 & 0 & 0 & 0 & 0 \\
\hline Others, define & 0 & 2 & 4 & 4 & 4 & 4 & 0 & 0 & 0 & 0 & 0 & 0 & 0 & 0 \\
\hline
\end{tabular}

Quality Program:

Company A currently maintains a QA program in accordance with 10CFR50 Appendix B or NQA-1 to support the nuclear industry.

Threshold for Additional Expansion and Lead Time:

Company A stated that they would add positions immediately upon receipt of the first order. Expansion of existing facilities, or addition of new fabrication facilities would be required for subsequent orders. Company A stated that they could expand facilities or add facilities given a 3month lead-time.

Incentives and Constraints:

Company A stated that contracts and commitments would be required to consider expanding existing facilities or to add new facilities. Company A does not have any overseas content and did not envision doing any fabrication offshore; however, they did point out that a certain percentage of the raw materials used today are milled overseas. Company A's primary concern for supporting the build-out was obtaining raw materials. Currently they are being supplied on an allotment arrangement from the mills for the Northwest region and see a shortage of scrap metal, used to manufacture reinforcing steel, as a constraint.

Other Issues:

Company A saw cheaper energy as a benefit to the potential build-out of new nuclear generation. They have also not discussed the issue of job creation in the U.S. within the confines of their trade association (Concrete Reinforcing Steel Institute - CRSI). 


\section{Survey Results-Company B}

Current Employment:

Current employment level of the company's manufacturing business. Also, the number of jobs located domestically and outside the U.S. and the percentage of employees who have current or past nuclear experience.

\begin{tabular}{|l|c|c|c|}
\hline \multicolumn{1}{|c|}{ Category } & $\begin{array}{c}\text { Current } \\
\text { Employee } \\
\text { Level in U.S. }\end{array}$ & $\begin{array}{c}\text { Number } \\
\text { Outside the } \\
\text { U.S. }\end{array}$ & $\begin{array}{c}\text { \% With } \\
\text { Nuclear } \\
\text { Experience }\end{array}$ \\
\hline Manufacturing Trades * & 800 & 0 & 65 \\
\hline Engineering & 86 & 0 & 2 \\
\hline QA/QC & 36 & 0 & 12 \\
\hline Shipping and Receiving & 28 & 0 & 21 \\
\hline $\begin{array}{l}\text { Field Support (startup, service, training, } \\
\text { warranty, etc.) }\end{array}$ & 0 & 0 & 0 \\
\hline Others, Sales, G\&A & & & \\
\hline
\end{tabular}

Output, Capacity, and Market Share:

Manufacturing output (e.g., number of units produced annually) at the current employment level and shop load percentage at this production rate. This company's domestic market share and current overseas market share. This company's yearly sales volume and the percentage of this sales volume related to domestic/U.S. production.

Total $=\$ 540 \mathrm{M} /$ year, all domestic

$80 \%$ capacity $(600,000$ tons/year)

$10 \%$ domestic market share

$50 \%$ regional market share

$0 \%$ overseas market share 
Projected Job Growth:

Considering the company's expected market share, the following tables shows the number of additional U.S. jobs created as a result of the projected industry growth to support new nuclear plants.

\begin{tabular}{|c|c|c|c|c|c|c|c|c|c|c|c|c|c|c|}
\hline Category & ‘09 & 10 & '11 & '12 & '13 & '14 & '15 & '16 & '17 & '18 & ‘19 & 20 & 21 & 22 \\
\hline Manufacturing Trades & 100 & 20 & 20 & 20 & 20 & 20 & 20 & 20 & 20 & 20 & 20 & 20 & 0 & 0 \\
\hline Engineering & 8 & 2 & 2 & 2 & 2 & 2 & 2 & 2 & 2 & 2 & 2 & 2 & 0 & 0 \\
\hline QA/QC & 12 & 1 & 1 & 1 & 1 & 1 & 1 & 1 & 1 & 1 & 1 & 1 & 0 & 0 \\
\hline Shipping and Receiving & $*$ & $*$ & $*$ & $*$ & $*$ & $*$ & $*$ & $*$ & $*$ & $*$ & $*$ & $*$ & 0 & 0 \\
\hline $\begin{array}{l}\text { Field Support (SU, service, } \\
\text { training, warranty, etc.) }\end{array}$ & 0 & 0 & 0 & 0 & 0 & 0 & 0 & 0 & 0 & 0 & 0 & 0 & 0 & 0 \\
\hline Others Sales \& G\&A & 0 & 0 & 0 & 0 & 0 & 0 & 0 & 0 & 0 & 0 & 0 & 0 & 0 & 0 \\
\hline
\end{tabular}

* Included with Manufacturing Trades

Quality Program:

Company B currently maintains a QA program in accordance with 10CFR50 Appendix B or NQA-1 to support the nuclear industry.

Threshold for Additional Expansion and Lead Time:

Company B stated they would need to add positions immediately upon receipt of the first order and would need to add facilities by the third unit in the build-out schedule. In order to support the addition of facilities, Company B would require a 3-year lead-time.

Incentives and Constraints:

Company B stated that tax incentives, assistance with land acquisitions, and assistance with employee training would be required for them to increase domestic manufacturing capacity. Company B expressed concern will the build-out schedule and the associated ramp-up, which would require additional fabrication facilities to support the demand.

Other Issues:

Company B saw lesser dependence on other fuel sources and environmental improvements as benefits to potential build-out of new nuclear generation. They have also not discussed the issue of job creation in the U.S. within the confines of their trade association (Concrete Reinforcing Steel Institute - CRSI). 


\section{Commodity Summary and Indicators}

According to the Portland Cement Association (PCA) Spring 2004 Market Analysis, $112,000,000 \mathrm{MT}$ of cement are consumed annually in the U.S. Of this, approximately $20 \%$ is imported and 80\% manufactured domestically. PCA forecast consumption to rise between 1\% and $2 \%$ annually with imports remaining at about the same percentage. For the new nuclear generation plants, it has been estimated that 4,000,000 MT of cement would be required over a 10 -year period. Based on PCA forecast this would represent less than $1 \%$ of the overall cement market. As such, regional impacts could be felt; however, overall, few or no measurable impacts are foreseen in the cement sector.

In the U.S. today, approximately 8,000,000 tons of reinforcing steel are consumed annually. For the new nuclear generation plants, it has been estimated that 1,000,000 tons of reinforcing steel would be required for construction. Over a 10-year period, this would represent approximately $1 \%$ of the overall market. As with cement, regional impacts may be expected; however, overall impacts should be negligible with respect to raw materials.

Fabrication of reinforcing steel is labor intensive and as shown above, moderate job growth would be seen. In addition to job growth, the need for added facilities for fabrication would also be needed.

\section{Special Issues}

Company $\mathrm{B}$ has a serious concern regarding the complexities associated with adding facilities to meet this potential demand. In addition to the hardware issues, Company B also expressed reservations regarding employee training and the ability to staff for this work.

\section{Data Observations by Bechtel}

Both companies interviewed are currently supplying to nuclear standards and are familiar with the associated rules and regulations. However, as seen in the data above, these two companies represent extremes in volume and market share. The data provided for each associated with potential job growth varies significantly. Company A projects 230 additional jobs for the additional 1,000,000 tons of reinforcing steel. This equates to a production rate per employee of approximately 20 times its current rate. Company B on the other hand, projects 380 additional jobs for the added demand. This equates to a production rate per employee of approximately 4 times its current rate.

The projections for job growth provided by each would appear to be under-estimated, with Company B's projections being somewhat more realistic. Based on information provided regarding current production rates and staffing, it is reasonable to assume up to 1,000 jobs would be needed to support the demand associated with new nuclear generation plants. 
Compressors/Vacuum Pumps

No supplier feedback for this commodity. 


\section{Survey Results-Company A}

\section{Current Employment:}

Current employment level of the company's manufacturing business. Also, the number of jobs located domestically and outside the U.S. and the percentage of employees who have current or past nuclear experience.

Company A has total of 177 employees with approximately 55 employees in the condenser division and rest of the employees are in a wholly owned subsidiary which produces heat exchangers and spent fuel storage equipment. Table below provides the current employment level of the company's manufacturing business. Also, the number of jobs located domestically and outside the U.S. and the percentage of employees who have current or past nuclear experience.

\begin{tabular}{|c|c|c|c|}
\hline Category & $\begin{array}{c}\text { Current } \\
\text { Employee } \\
\text { Level in U.S. }\end{array}$ & $\begin{array}{l}\text { Number } \\
\text { Outside the } \\
\text { U.S. }\end{array}$ & $\begin{array}{c}\text { \% With } \\
\text { Nuclear } \\
\text { Experience }\end{array}$ \\
\hline $\begin{array}{l}\text { Manufacturing Trades (Welders + Non } \\
\text { Welders) }\end{array}$ & $50+40$ & $\mathrm{~N} / \mathrm{A}$ & 100 \\
\hline Engineering & 40 & & 90 \\
\hline $\mathrm{QA} / \mathrm{QC}$ & 16 & & 100 \\
\hline Shipping and Receiving & 4 & & 90 \\
\hline $\begin{array}{l}\text { Field Support (startup, service, training, } \\
\text { warranty, etc.) }\end{array}$ & & & \\
\hline Others, define & 26 & $\downarrow$ & 90 \\
\hline
\end{tabular}

Output, Capacity, and Market Share:

Manufacturing output (e.g., number of units produced annually) at the current employment level and shop load percentage at this production rate. This company's domestic market share and current overseas market share. This company's yearly sales volume and the percentage of this sales volume related to domestic/U.S. production.

24 Condensers/year

$30 \%$ U.S. market share

$10 \%$ overseas market share 
Projected Job Growth:

Considering the company's expected market share, the following tables shows the number of additional U.S. jobs created as a result of the projected industry growth to support new nuclear plants.

\begin{tabular}{|c|c|c|c|c|c|c|c|c|c|c|c|c|c|c|}
\hline Category & '09 & '10 & '11 & '12 & $' 13$ & $' 14$ & $' 15$ & ‘ 16 & $\cdot 17$ & $' 18$ & '19 & '20 & '21 & '22 \\
\hline Manufacturing Trades & 40 & 20 & 20 & 20 & 0 & 0 & 0 & 0 & 0 & 0 & 0 & 0 & 0 & 0 \\
\hline Engineering & 5 & 3 & 3 & 3 & 0 & 0 & 0 & 0 & 0 & 0 & 0 & 0 & 0 & 0 \\
\hline $\mathrm{QA} / \mathrm{QC}$ & & & & & & & & & & & & & & \\
\hline Shipping and Receiving & & & & & & & & & & & & & & \\
\hline $\begin{array}{l}\text { Field Support (SU, service, } \\
\text { training, warranty, etc.) }\end{array}$ & & & & & & & & & & & & & & \\
\hline Others, define & $\nabla$ & $\downarrow$ & 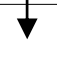 & $\downarrow$ & 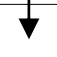 & $\downarrow$ & 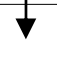 & $\downarrow$ & $\nabla$ & 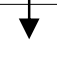 & $\downarrow$ & $\downarrow$ & $\nabla$ & $\downarrow$ \\
\hline
\end{tabular}

\section{Quality Program:}

Company A currently maintains a QA program in accordance with 10CFR50 Appendix B or NQA-1 to support the nuclear industry.

Threshold for Additional Expansion and Lead Time:

Company A stated that addition of one new plant will initiate the job growth. Company A stated that they require 1 to 2 years of lead-time for the company to make a decision to build new production capacity.

Incentives and Constraints:

Company A stated that only a letter of intent for the purchase of their product approximately 9 months before the order will be necessary. They see a shortage of raw materials, e.g., carbon and stainless steel as constraints for their market.

Other Issues:

None. 


\section{Commodity Summary and Indicators}

Two suppliers were approached for this commodity. Only one company provided the input. Company A, claims 30\% market share, and is projecting job growth of 170 jobs starting in Year 2009 through 2012.

There are strong indications that there would be some moderate growth in manufacturing jobs.

\section{Special Issues}

Company A has a concern regarding the shortage in carbon steel supply and energy costs for the manufacturing sector. 
Cooling Towers

No supplier feedback for this commodity. 


\section{Survey Results-Company A}

Current Employment:

Current employment level of the company's manufacturing business. Also, the number of jobs located domestically and outside the U.S. and the percentage of employees who have current or past nuclear experience.

\begin{tabular}{|l|c|c|c|}
\hline \multicolumn{1}{|c|}{ Category } & $\begin{array}{c}\text { Current } \\
\text { Employee } \\
\text { Level in U.S. }\end{array}$ & $\begin{array}{c}\text { Number } \\
\text { Outside the } \\
\text { U.S. }\end{array}$ & $\begin{array}{c}\text { \% With } \\
\text { Nuclear } \\
\text { Experience }\end{array}$ \\
\hline Manufacturing Trades & 314 & 213 & N/A \\
\hline Engineering & 188 & 112 & $10 \%$ \\
\hline QA/QC & 31 & 22 & $80 \%$ \\
\hline Shipping and Receiving & 10 & 8 & N/A \\
\hline $\begin{array}{l}\text { Field Support (startup, service, training, } \\
\text { warranty, etc.) }\end{array}$ & 83 & 44 & $30 \%$ \\
\hline Others, define & & & \\
\hline
\end{tabular}

Output, Capacity, and Market Share:

Manufacturing output (e.g., number of units produced annually) at the current employment level and shop load percentage at this production rate. This company's domestic market share and current overseas market share. This company's yearly sales volume and the percentage of this sales volume related to domestic/U.S. production.

In U.S. \$84M/year. \$216M/year outside the U.S.

$60 \%$ capacity (1 full shift plus parts of other shifts)

$20 \%$ domestic market share

$40 \%$ overseas market share 
Projected Job Growth:

Considering the company's expected market share, the following tables shows the number of additional U.S. jobs created as a result of the projected industry growth to support new nuclear plants.

\begin{tabular}{|c|c|c|c|c|c|c|c|c|c|c|c|c|c|c|}
\hline Category & '09 & '10 & ‘11 & '12 & '13 & '14 & ' 15 & '16 & ‘ 17 & '18 & '19 & $‘^{20}$ & '21 & '22 \\
\hline Manufacturing Trades & $*$ & & & & & & & & & & & & & \\
\hline Engineering & $*$ & & & & & & & & & & & & & \\
\hline $\mathrm{QA} / \mathrm{QC}$ & $*$ & & & & & & & & & & & & & \\
\hline Shipping and Receiving & $*$ & & & & & & & & & & & & & \\
\hline $\begin{array}{l}\text { Field Support (SU, service, } \\
\text { training, warranty, etc.) }\end{array}$ & $*$ & & & & & & & & & & & & & \\
\hline Others, define & $*$ & & & & & & & & & & & & & \\
\hline
\end{tabular}

* Company A stated that by 2009 they would have 3 times the current level of employees (3300 employees) from nuclear business in Finland, Korea, and China (a total of 7-9 1000 MWe units). After that buildup they would not need new employees.

\section{Quality Program:}

Company A currently maintains a QA program in accordance with 10CFR50 Appendix B or NQA-1 to support the nuclear industry.

Threshold for Additional Expansion and Lead Time:

Company A stated that the business at the time would determine what threshold of demand for their products would cause U.S. jobs be created to support new nuclear plants. Company A stated that they require less than 1 year of lead-time for the company to make a decision to build new production capacity.

Incentives and Constraints:

Company A stated that contracts that require "buy U.S. products" clause would be an incentive required to build new manufacturing capacity in the U.S. Company A had no known incentives that would be required to repatriate jobs to the U.S. They also did not identify any constraints, concerns, or other issues that may arise as a result of the additional demands on their subsuppliers for materials, products and services.

\section{Other Issues:}

Company A saw no other internal business benefits, other than U.S. job growth to the potential build-out of new nuclear generation. They have also not discussed the issue of job creation in the U.S. within the confines of any of their respective trade associations. 


\section{Survey Results-Company B}

Current Employment:

Current employment level of the company's manufacturing business. Also, the number of jobs located domestically and outside the U.S. and the percentage of employees who have current or past nuclear experience.

\begin{tabular}{|l|c|c|c|}
\hline \multicolumn{1}{|c|}{ Category } & $\begin{array}{c}\text { Current } \\
\text { Employee } \\
\text { Level in U.S. }\end{array}$ & $\begin{array}{c}\text { Number } \\
\text { Outside the } \\
\text { U.S. }\end{array}$ & $\begin{array}{c}\text { \% With } \\
\text { Nuclear } \\
\text { Experience }\end{array}$ \\
\hline Manufacturing Trades * & 660 & 1340 & $10 \%$ \\
\hline Engineering & 165 & 335 & $10 \%$ \\
\hline QA/QC & 66 & 134 & $10 \%$ \\
\hline Shipping and Receiving & 66 & 134 & $10 \%$ \\
\hline $\begin{array}{l}\text { Field Support (startup, service, training, } \\
\text { warranty, etc.) }\end{array}$ & 198 & 402 & $10 \%$ \\
\hline Others, Sales, G\&A & 165 & 335 & $10 \%$ \\
\hline
\end{tabular}

Output, Capacity, and Market Share:

Manufacturing output (e.g., number of units produced annually) at the current employment level and shop load percentage at this production rate. This company's domestic market share and current overseas market share. This company's yearly sales volume and the percentage of this sales volume related to domestic/U.S. production.

50,000 units per year

$90 \%$ capacity

$35 \%$ domestic market share

$15-20 \%$ overseas market share

$\$ 600 \mathrm{M}$ worldwide sales revenue

$\$ 300 \mathrm{M}$ domestic sales volume 
Projected Job Growth:

Considering the company's expected market share, the following tables shows the number of additional U.S. jobs created as a result of the projected industry growth to support new nuclear plants.

\begin{tabular}{|c|c|c|c|c|c|c|c|c|c|c|c|c|c|c|}
\hline Category & ‘ 09 & '10 & ‘11 & '12 & '13 & '14 & ‘ 15 & ' 16 & ‘17 & ' 18 & ‘19 & 20 & 21 & 22 \\
\hline Manufacturing Trades & 50 & 50 & 50 & 50 & 25 & 25 & 25 & 25 & 25 & 25 & 5 & 5 & 5 & 5 \\
\hline Engineering & 25 & 25 & 25 & 25 & 10 & 10 & 10 & 10 & 10 & 10 & 0 & 0 & 0 & 0 \\
\hline $\mathrm{QA} / \mathrm{QC}$ & 10 & 10 & 10 & 10 & 5 & 5 & 5 & 5 & 5 & 5 & 0 & 0 & 0 & 0 \\
\hline Shipping and Receiving & 10 & 10 & 10 & 10 & 5 & 5 & 5 & 5 & 5 & 5 & 0 & 0 & 0 & 0 \\
\hline $\begin{array}{l}\text { Field Support (SU, service, } \\
\text { training, warranty, etc.) }\end{array}$ & 30 & 30 & 30 & 30 & 20 & 20 & 20 & 20 & 20 & 20 & 10 & 10 & 10 & 10 \\
\hline Others Sales \& G\&A & 10 & 10 & 10 & 10 & 5 & 5 & 5 & 5 & 5 & 5 & 0 & 0 & 0 & 0 \\
\hline
\end{tabular}

Quality Program:

Company B currently maintains a QA program in accordance with 10CFR50 Appendix B or NQA-1 to support the nuclear industry. They also maintain an "N" Stamp in the U.S. and have similar qualifications in France and Japan.

Threshold for Additional Expansion and Lead Time:

Company B stated they currently operate 2.5 shifts at the present time and would use the same facilities for the $1^{\text {st }}$ plant. They would consider adding facilities with the $2^{\text {nd }}$ new plant order. Company B stated that they require 2 years of lead-time for the company to build new production capacity and it would require 2 years for the foundry business to build back up.

Incentives and Constraints:

Company B stated that tax incentives would be required for them to both repatriate jobs to the U.S. and increase domestic manufacturing capacity. Company B would not build new facilities but would increase machining capability. Company B also expressed concern over the difference in cost between U.S. and overseas Labor. Company B also has a serious concern in foundry capability in the U.S. Foundry capability in the U.S. has declined significantly. They use 4-5 on a routine basis. The U.S. has lost $80 \%$ of foundry capacity in the last 20 years and quality is suffering.

Other Issues:

Company B saw a benefit better mix of energy sources and cheaper power due to potential buildout of new nuclear generation. They have also not discussed the issue of job creation in the U.S. within the confines of their trade association (Valve Manufacturers Association) because this issue is not a high priority with them.

\section{Commodity Summary and Indicators}

Two suppliers were surveyed for this commodity. Company A, who claims $20 \%$ market share, is projecting job growth between now and 2009, driven by the off-shore market for nuclear plant 
control valves but expect no job growth due to the rebirth of the domestic nuclear market. They would simply shift resources from foreign projects to domestic projects. Company A projects adding 628 manufacturing jobs to support their off-shore work by 2009 and 624 support jobs.

Company B claims $15 \%$ to $20 \%$ of the domestic market and projects to add 370 manufacturing jobs between 2009 and 2022 due to the deployment of new nuclear facilities in the U.S. In addition, Company B would add 750 support jobs as well.

There are strong indications that there would be some moderate growth in manufacturing jobs, for this sector as well as a sustaining of jobs that will have been added to support the current active international market for nuclear quality control valves.

\section{Special Issues}

Company B has a serious concern in the foundry capability in the U.S. Foundry capability in the U.S. has declined significantly in the last 20 years and quality is suffering. We received this feedback other suppliers contacted in this survey.

\section{Data Observations by Bechtel}

Company A provided current employment, projected employment, and projected job growth from additional U.S. nuclear power generation that does not seem consistent. The current level of employment at Company A of 1100 is projected to triple to 3300 by the year 2009 based on overseas nuclear plant construction of 7 to 9 plants. Company A expressed it would be difficult to project additional job growth based on the U.S. nuclear plant projection and felt they wouldn't need additional employees to meet this projection. An evaluation of the staffing growth from 7 to 9 plants (2200 employees) would suggest that no additional job growth for 33 to 41 new nuclear plants is unduly conservative and may result from Company A's concern for the demand in other company business lines not being defined as a part of this study.

A further comparison to Company B's job growth projections of 3.4\% with the first plant order and further additions in the following years reinforce the belief that Company A's projection of no new jobs is conservatively low and may not be based on the same premises as Company B's projection. 


\section{Survey Results-Company A}

Current Employment:

Current employment level of the company's manufacturing business. Also, the number of jobs located domestically and outside the U.S. and the percentage of employees who have current or past nuclear experience.

\begin{tabular}{|l|c|c|c|}
\hline \multicolumn{1}{|c|}{ Category } & $\begin{array}{c}\text { Current } \\
\text { Employee } \\
\text { Level in U.S. }\end{array}$ & $\begin{array}{c}\text { Number } \\
\text { Outside the } \\
\text { U.S. }\end{array}$ & $\begin{array}{c}\text { \% With } \\
\text { Nuclear } \\
\text { Experience }\end{array}$ \\
\hline Manufacturing Trades & 19 & 0 & 100 \\
\hline Engineering & 27 & 0 & 100 \\
\hline QA/QC & 4 & 0 & 100 \\
\hline Shipping and Receiving & 1 & 0 & 100 \\
\hline $\begin{array}{l}\text { Field Support (startup, service, training, } \\
\text { warranty, etc.) }\end{array}$ & 3 & 0 & 100 \\
\hline Others, define & 26 & 2 & 70 \\
\hline
\end{tabular}

Output, Capacity, and Market Share:

Manufacturing output (e.g., number of units produced annually) at the current employment level and shop load percentage at this production rate. This company's domestic market share and current overseas market share. This company's yearly sales volume and the percentage of this sales volume related to domestic/U.S. production.

Total \$16M/year, currently all domestic

$75 \%$ capacity (10 customized/specialized cranes per year)

$1 \%$ domestic market share

$0 \%$ overseas market share

Mix between overseas and domestic market varies year to year 
Projected Job Growth:

Considering the company's expected market share, the following tables shows the number of additional U.S. jobs created as a result of the projected industry growth to support new nuclear plants.

\begin{tabular}{|c|c|c|c|c|c|c|c|c|c|c|c|c|c|c|}
\hline Category & '09 & ‘10 & ‘ 11 & $\cdot 12$ & '13 & ‘14 & '15 & '16 & '17 & '18 & 19 & 20 & 21 & 22 \\
\hline Manufacturing Trades & 6 & 12 & 16 & 16 & 20 & 20 & 20 & 20 & 20 & 20 & 20 & 0 & 0 & 0 \\
\hline Engineering & 2 & 3 & 3 & 3 & 4 & 4 & 4 & 4 & 4 & 4 & 4 & 0 & 0 & 0 \\
\hline QA/QC & 0 & 1 & 1 & 1 & 2 & 2 & 2 & 2 & 2 & 2 & 2 & 0 & 0 & 0 \\
\hline Shipping and Receiving & 0 & 0 & 0 & 0 & 0 & 0 & 0 & 0 & 0 & 0 & 0 & 0 & 0 & 0 \\
\hline $\begin{array}{l}\text { Field Support (SU, service, } \\
\text { training, warranty, etc.) }\end{array}$ & 1 & 2 & 3 & 3 & 4 & 4 & 4 & 4 & 4 & 4 & 4 & 0 & 0 & 0 \\
\hline Others, define & 0 & 1 & 2 & 2 & 3 & 3 & 3 & 3 & 3 & 3 & 3 & 0 & 0 & 0 \\
\hline
\end{tabular}

\section{Quality Program:}

Company A currently maintains a QA program in accordance with 10CFR50 Appendix B or NQA-1 to support the nuclear industry.

Threshold for Additional Expansion and Lead Time:

Company A stated if they received orders for 2 to 3 special purpose nuclear cranes per year they would create new jobs at their plant upon receipt of the order and would substantially increase the their outsourcing volume to the local community and to specialized supplier around the U.S. Company A stated that they did not foresee a need to add production capacity for new nuclear generation. They could triple their output by adding shifts and increasing the amount of outsourcing utilizing their current infrastructure without having to add new facilities.

Incentives and Constraints:

Company A stated that they had no plans to add facilities therefore noted no incentives. Likewise on the subject of repatriating job to the U.S., Company A does not currently rely on offshore work or services. They also did not identify any constraints, concerns, or other issues that may arise as a result of the additional demands on their subsuppliers for materials, products and services.

Other Issues:

Company A identified reduced dependence on imported oil and reduced environmental impacts from mining and emissions as benefits, other than U.S. job growth to the potential build-out of new nuclear generation. They have discussed new nuclear generation at ASME Committee meetings (Committee on Cranes for Nuclear Facilities) but only in the terms of increased optimism about the future of new plant construction, not specifically about job creation. 


\section{Survey Results-Company B}

Current Employment:

Current employment level of the company's manufacturing business. Also, the number of jobs located domestically and outside the U.S. and the percentage of employees who have current or past nuclear experience.

\begin{tabular}{|l|c|c|c|}
\hline \multicolumn{1}{|c|}{ Category } & $\begin{array}{c}\text { Current } \\
\text { Employee } \\
\text { Level in U.S. }\end{array}$ & $\begin{array}{c}\text { Number } \\
\text { Outside the } \\
\text { U.S. }\end{array}$ & $\begin{array}{c}\text { \% With } \\
\text { Nuclear } \\
\text { Experience }\end{array}$ \\
\hline Manufacturing Trades * & 40 & 0 & 20 \\
\hline Engineering & 25 & 0 & 30 \\
\hline QA/QC & 4 & 0 & 75 \\
\hline Shipping and Receiving & 2 & 0 & 50 \\
\hline $\begin{array}{l}\text { Field Support (startup, service, training, } \\
\text { warranty, etc.) }\end{array}$ & 35 & 0 & 40 \\
\hline Others, Sales, G\&A & 14 & 0 & 10 \\
\hline
\end{tabular}

Output, Capacity, and Market Share:

Manufacturing output (e.g., number of units produced annually) at the current employment level and shop load percentage at this production rate. This company's domestic market share and current overseas market share. This company's yearly sales volume and the percentage of this sales volume related to domestic/U.S. production.

Total \$18M/year, currently all domestic

$80 \%$ capacity (20 customized/specialized cranes per year)

$20 \%$ domestic market share

$0 \%$ overseas market share 
Projected Job Growth:

Considering the company's expected market share, the following tables shows the number of additional U.S. jobs created as a result of the projected industry growth to support new nuclear plants.

\begin{tabular}{|c|c|c|c|c|c|c|c|c|c|c|c|c|c|c|}
\hline Category & ‘09 & ' 10 & ' 11 & ' 12 & ' 13 & '14 & ‘ 15 & '16 & ‘17 & ' 18 & '19 & 20 & 21 & 22 \\
\hline Manufacturing Trades & 10 & 20 & 30 & 50 & 75 & 20 & 20 & 20 & 20 & 20 & 20 & 20 & 20 & 20 \\
\hline Engineering & 2 & 5 & 15 & 20 & 30 & 7 & 7 & 7 & 7 & 7 & 7 & 7 & 7 & 7 \\
\hline QA/QC & 3 & 4 & 5 & 8 & 10 & 3 & 3 & 3 & 3 & 3 & 3 & 3 & 3 & 3 \\
\hline Shipping and Receiving & 3 & 4 & 5 & 6 & 6 & 2 & 2 & 2 & 2 & 2 & 2 & 2 & 2 & 2 \\
\hline $\begin{array}{l}\text { Field Support (SU, service, } \\
\text { training, warranty, etc.) }\end{array}$ & 5 & 6 & 7 & 8 & 10 & 4 & 4 & 4 & 4 & 4 & 4 & 4 & 4 & 4 \\
\hline Others Sales \& G\&A & 2 & 4 & 8 & 10 & 10 & 3 & 3 & 3 & 3 & 3 & 3 & 3 & 3 & 3 \\
\hline
\end{tabular}

Quality Program:

Company B currently maintains a QA program in accordance with 10CFR50 Appendix B or NQA-1 to support the nuclear industry.

Threshold for Additional Expansion and Lead Time:

Company B stated they would need to add jobs and potentially expand their existing facility upon receipt of the order for the second new nuclear generation plant. Company B states that a 2year lead time would be required to support expansion of their existing facility to support a full build-out of new nuclear generation plants.

Incentives and Constraints:

Company B stated that a long term commitment to new nuclear generation plants would be the incentive required for them to both repatriate jobs to the U.S. and increase domestic manufacturing capacity. Company B would not build new facilities but would expand their existing facilities. Company B also expressed concern over the ability to obtain skilled/experience personnel to support the re-emergence of nuclear projects.

Other Issues:

Company B saw environmental improvements and the ability to develop skilled labor as benefits due to potential build-out of new nuclear generation. They have discussed the issue of job creation in the U.S. within their company; however, they were not aware of any discussions with trade organizations on the subject (Crane Manufacturers Association - CMA). 


\section{Commodity Summary and Indicators}

Two suppliers were surveyed for this commodity. Both companies indicated that there would be some moderate growth in manufacturing jobs, for this sector as well as job growth for its subsuppliers associate with the deployment of new nuclear facilities in the U.S.

\section{Special Issues}

Company B expressed concerns regarding their ability to find skilled craft and experienced personnel to support the potential for re-emerging nuclear projects.

\section{Data Observations by Bechtel}

Both companies reported nearly identical domestic sales volume; however, Company B's market share was reported to be significantly larger than Company A's. A disparity in job growth numbers also exists between the two companies.

The domestic market share reported by each company may represent different or select market sectors. There is a large range of cranes manufactured, considering size, type and complexity. Both companies interviewed have been and were actively involved in supplying cranes for nuclear facilities and maintain some level of expertise through ongoing maintenance for existing nuclear facilities.

Regarding the apparent disparity in job growth projects, Company A has assumed a higher degree on standardization than Company B. Company A's projects would represent an optimistic view while Company B's projections would represent a pessimistic approach. With both companies equally qualified, Company B has assumed design similar to past nuclear plants where little or no standardization was achieved. 


\section{Dampers/Louvers}

No supplier feedback for this commodity. 


\section{Diesel Generators}

\section{Survey Results_Company A}

Current Employment:

Current employment level of the company's manufacturing business. Also, the number of jobs located domestically and outside the U.S. and the percentage of employees who have current or past nuclear experience.

\begin{tabular}{|l|c|c|c|}
\hline \multicolumn{1}{|c|}{ Category } & $\begin{array}{c}\text { Current } \\
\text { Employee } \\
\text { Level in U.S. }\end{array}$ & $\begin{array}{c}\text { Number } \\
\text { Outside the } \\
\text { U.S. }\end{array}$ & $\begin{array}{c}\text { \% With } \\
\text { Nuclear } \\
\text { Experience }\end{array}$ \\
\hline Manufacturing Trades & 5000 & 2000 & 0 \\
\hline Engineering & 1000 & 200 & 1 \\
\hline QA/QC & & & 0 \\
\hline Shipping and Receiving & & & 0 \\
\hline $\begin{array}{l}\text { Field Support (startup, service, training, } \\
\text { warranty, etc.) }\end{array}$ & & & 1 \\
\hline Others, define & 2000 & 500 & \\
\hline
\end{tabular}

Output, Capacity, and Market Share:

Manufacturing output (e.g., number of units produced annually) at the current employment level and shop load percentage at this production rate. This company's domestic market share and current overseas market share. This company's yearly sales volume and the percentage of this sales volume related to domestic/U.S. production.

In U.S. $\$ 500 \mathrm{M} /$ year. $\$ 500 \mathrm{M} /$ year outside the U.S.

$80 \%$ capacity $(8,000$ Units/year)

$40 \%$ domestic market share

$30 \%$ overseas market share 
Projected Job Growth:

Considering the company's expected market share, the following tables shows the number of additional U.S. jobs created as a result of the projected industry growth to support new nuclear plants.

\begin{tabular}{|c|c|c|c|c|c|c|c|c|c|c|c|c|c|c|}
\hline Category & ‘09 & '10 & '11 & '12 & ‘13 & '14 & ' 15 & ' 16 & ' 17 & '18 & ‘ 19 & '20 & '21 & 22 \\
\hline \multicolumn{15}{|l|}{ Manufacturing Trades } \\
\hline Engineering & & 5 & & & & & & & & & & & & \\
\hline \multicolumn{15}{|l|}{$\mathrm{QA} / \mathrm{QC}$} \\
\hline \multicolumn{15}{|l|}{ Shipping and Receiving } \\
\hline $\begin{array}{l}\text { Field Support (SU, service, } \\
\text { training, warranty, etc.) }\end{array}$ & & 2 & & & & & & & & & & & & \\
\hline Others, define & & & & & & & & & & & & & & \\
\hline
\end{tabular}

\section{Quality Program:}

Company A currently does not maintain a QA program in accordance with 10CFR50 Appendix B or NQA-1 to support the nuclear industry. Company A allowed its Nuclear QA Manual to lapse based on not having any sales volume related to the nuclear industry in recent years

Threshold for Additional Expansion and Lead Time:

Company A currently manufactures over 8,000 units per year. It is estimated that new nuclear generation would result in an added demand of 4 to 5 units per year over a 15 -year period. This added demand as compared with Company A's current capacity would not result in any significant expansion to either jobs or facilities

Incentives and Constraints:

Company A did not identify any specific incentives required to build new manufacturing capacity or to repatriate jobs. The most significant constraint identified by Company A for new nuclear generation would be the current lack of nuclear qualifications within its Company and among its subsuppliers.

Other Issues:

Company A saw no internal business benefits, other than U.S. job growth to the potential buildout of new nuclear generation. They have also not discussed the issue of job creation in the U.S. within the confines of any of their respective trade associations. 


\section{Survey Results-Company B}

Current Employment:

Current employment level of the company's manufacturing business. Also, the number of jobs located domestically and outside the U.S. and the percentage of employees who have current or past nuclear experience.

\begin{tabular}{|l|c|c|c|}
\hline \multicolumn{1}{|c|}{ Category } & $\begin{array}{c}\text { Current } \\
\text { Employee } \\
\text { Level in U.S. }\end{array}$ & $\begin{array}{c}\text { Number } \\
\text { Outside the } \\
\text { U.S. }\end{array}$ & $\begin{array}{c}\text { \% With } \\
\text { Nuclear } \\
\text { Experience }\end{array}$ \\
\hline Manufacturing Trades * & 100 & 0 & 0 \\
\hline Engineering & 10 & 2 & 0 \\
\hline QA/QC & 10 & 0 & 1 \\
\hline Shipping and Receiving & 5 & 0 & 0 \\
\hline $\begin{array}{l}\text { Field Support (startup, service, training, } \\
\text { warranty, etc.) }\end{array}$ & 10 & 4 & 0 \\
\hline Others, Sales, G\&A & 4 & 0 & 0 \\
\hline
\end{tabular}

Output, Capacity, and Market Share:

Manufacturing output (e.g., number of units produced annually) at the current employment level and shop load percentage at this production rate. This company's domestic market share and current overseas market share. This company's yearly sales volume and the percentage of this sales volume related to domestic/U.S. production.

\section{$\$ 45 \mathrm{M} /$ year.}

$60 \%$ capacity (20 Units/year)

$5 \%$ domestic market share

$<1 \%$ overseas market share

Projected Job Growth:

Considering the company's expected market share, the following tables shows the number of additional U.S. jobs created as a result of the projected industry growth to support new nuclear plants.

\begin{tabular}{|c|c|c|c|c|c|c|c|c|c|c|c|c|c|c|}
\hline Category & 69 & '10 & '11 & '12 & '13 & $' 14$ & '15 & '16 & '17 & '18 & '19 & '20 & '21 & 22 \\
\hline Manufacturing Trades & 8 & 8 & 8 & 12 & 12 & 15 & 15 & 15 & 15 & 15 & 0 & 0 & 0 & 0 \\
\hline Engineering & 1 & 1 & 1 & 1 & 1 & 1 & 1 & 1 & 1 & 1 & 1 & 1 & 1 & 1 \\
\hline QA/QC & 1 & 1 & 1 & 1 & 1 & 1 & 1 & 1 & 1 & 1 & 1 & 1 & 1 & 1 \\
\hline Shipping and Receiving & 0 & 0 & 0 & 0 & 0 & 0 & 0 & 0 & 0 & 0 & 0 & 0 & 0 & 0 \\
\hline $\begin{array}{l}\text { Field Support (SU, service, } \\
\text { training, warranty, etc.) }\end{array}$ & 0 & 0 & 0 & 1 & 1 & 1 & 1 & 1 & 1 & 1 & 0 & 0 & 0 & 0 \\
\hline Others Sales \& G\&A & 0 & 0 & 0 & 0 & 0 & 1 & 1 & 1 & 1 & 1 & 1 & 1 & 1 & 1 \\
\hline
\end{tabular}


Quality Program:

Company B does not currently maintains a QA program in accordance with 10CFR50 Appendix B or NQA-1 to support the nuclear industry. They allowed their Nuclear QA Manual to lapse due to the decline in the nuclear industry in the late 70's combined with regulatory inconsistencies regarding specifications and standards.

Threshold for Additional Expansion and Lead Time:

Company B stated they would need to add positions upon the initial order and a decision to add manufacturing capacity would require a lead-time of 6 months.

Incentives and Constraints:

Company B stated that activities unique to the nuclear industry such as establishing an NQA-1 program, conducting specialized component testing, and establishing long-term document retention procedures cannot be justified as a commercial expense. Companies would look for incentives before incurring these costs, and may also look for methods to mitigate the risk of loss. Incentives such as long-term purchase commitments may be necessary to encourage manufacturers to commit their company's resources.

Other Issues:

Company B stated that most engine OEMs do not have NQA-1 programs in place, especially for the type and size required for new nuclear generation. This is because the engine OEMs that manufacturer large diesel engine is generally overseas. Air quality restrictions in North America on engine exhaust gases and low cost of foreign labor and materials has forced most large-bore manufacturers to move offshore.

Company B saw new nuclear generation along with plant forecasted for overseas as potential for increasing exports benefiting the U.S. GNP. They have also not discussed the issue of job creation in the U.S. within the confines of any of their respective trade associations. 


\section{Commodity Summary and Indicators}

Two suppliers were surveyed for this commodity. Combined, these two represent approximately $50 \%$ of the domestic market share and manufacturer over 8,000 diesel generator sets per year. Estimating that new nuclear generation would result in an added 60 to 80 units over the next 20 years, the growth in facilities and or jobs would be insignificant. This impacts associated with this added demand would be felt more by subsuppliers than the manufacturer's themselves.

\section{Special Issues}

Both companies expressed concerns related to re-establishing a Nuclear QA Program and had serious reservations regarding the capabilities of subsuppliers to qualify to new generation nuclear standards. Also as can be seen from the data presented, little or no past nuclear experience remains in this manufacturing sector.

\section{Data Observations by Bechtel}

None 


\section{Survey Results_Company A}

Current Employment:

Table below provides the current employment level of the company's manufacturing business. Also, the number of jobs located domestically and outside the U.S. and the percentage of employees who have current or past nuclear experience.

\begin{tabular}{|c|c|c|c|}
\hline Category & $\begin{array}{c}\text { Current } \\
\text { Employee } \\
\text { Level in U.S. }\end{array}$ & $\begin{array}{c}\text { Number } \\
\text { Outside the } \\
\text { U.S. }\end{array}$ & $\begin{array}{c}\text { \% With } \\
\text { Nuclear } \\
\text { Experience }\end{array}$ \\
\hline Manufacturing Trades & 75 & 0 & 90 \\
\hline Engineering & 15 & 1 & 80 \\
\hline QA/QC & 12 & & 50 \\
\hline Shipping and Receiving & 12 & & 90 \\
\hline $\begin{array}{l}\text { Field Support (startup, service, training, } \\
\text { warranty, etc.) }\end{array}$ & 10 & & 50 \\
\hline Others, define & 35 & & 20 \\
\hline
\end{tabular}

Output, Capacity, and Market Share:

Manufacturing output (e.g., number of units produced annually) at the current employment level and shop load percentage at this production rate. This company's domestic market share and current overseas market share. This company's yearly sales volume and the percentage of this sales volume related to domestic/U.S. production.

1,700 fans/year

$35 \%$ shop capacity

$50 \%$ U.S. market share

$5 \%$ International 
Projected Job Growth:

Considering the company's expected market share, the following tables shows the number of additional U.S. jobs created as a result of the projected industry growth to support new nuclear plants.

\begin{tabular}{|c|c|c|c|c|c|c|c|c|c|c|c|}
\hline Category & ‘ 09 & '10 & ‘11 & '12 & ' 13 & '14 & '15 & '16 & '17 & '18 & '19 \\
\hline Manufacturing Trades & 10 & 10 & 10 & 0 & 10 & 0 & 0 & 10 & 0 & 0 & 0 \\
\hline Engineering & 4 & 4 & 4 & 0 & 4 & 0 & 0 & 4 & 0 & 0 & 0 \\
\hline QA/QC & 4 & 3 & 3 & 0 & 3 & 0 & 0 & 3 & 0 & 0 & 0 \\
\hline Shipping and Receiving & 1 & 1 & 1 & 0 & 1 & 0 & 0 & 1 & 0 & 0 & 0 \\
\hline $\begin{array}{l}\text { Field Support (SU, service, } \\
\text { training, warranty, etc.) }\end{array}$ & 0 & 5 & 5 & 5 & 5 & 5 & 5 & 5 & 5 & 5 & 5 \\
\hline Others, define & 10 & 10 & 10 & 0 & 10 & 0 & 0 & 10 & 0 & 0 & 0 \\
\hline
\end{tabular}

Quality Program:

Company A currently maintains a QA program in accordance with 10CFR50 Appendix B or NQA-1 to support the nuclear industry.

Threshold for Additional Expansion and Lead Time:

Company A stated that addition of two new plant will initiate the job growth. Company A stated that they require 1 to 2 years of lead-time for the company to make a decision to build new production capacity.

Incentives and Constraints:

Company A stated that tax incentives and grants would provide positive impact in company's growth.

Other Issues:

Company A sees shortage in carbon steel supply and energy costs as constraints for the manufacturing sector. 


\section{Commodity Summary and Indicators}

Two suppliers were approached for this commodity. Only one company provided the input. Company A, claims 50\% market share, and is projecting job growth of 141 jobs.

There are strong indications that there would be some moderate growth in manufacturing jobs.

\section{Special Issues}

Company A has a concern for shortage in carbon steel supply and energy costs for the manufacturing sector. 


\section{Heat Exchangers}

\section{Survey Results-Company A}

Current Employment:

Current employment level of the company's manufacturing business. Also, the number of jobs located domestically and outside the U.S. and the percentage of employees who have current or past nuclear experience.

Company A has current employee level of 101 with breakdown per the table below:

\begin{tabular}{|c|c|c|c|}
\hline Category & $\begin{array}{c}\text { Current } \\
\text { Employee } \\
\text { Level in U.S. }\end{array}$ & $\begin{array}{c}\text { Number } \\
\text { Outside the } \\
\text { U.S. }\end{array}$ & $\begin{array}{c}\text { \% With } \\
\text { Nuclear } \\
\text { Experience }\end{array}$ \\
\hline Manufacturing Trades & 60 & 0 & $100 \%$ \\
\hline Engineering & 8 & & \\
\hline QA/QC & 9 & & \\
\hline Shipping and Receiving & 2 & & \\
\hline $\begin{array}{l}\text { Field Support (startup, service, training, } \\
\text { warranty, etc.) }\end{array}$ & 0 & & \\
\hline Others, define & 22 & $\downarrow$ & $\downarrow$ \\
\hline
\end{tabular}

Output, Capacity, and Market Share:

Manufacturing output (e.g., number of units produced annually) at the current employment level and shop load percentage at this production rate. This company's domestic market share and current overseas market share. This company's yearly sales volume and the percentage of this sales volume related to domestic/U.S. production.

Company spends 120,000 man-hours annually

$80-85 \%$ of the capacity is used. Long term capacity projection is not available

Current domestic market share is not known because they don't track this metric. $\$ 25 \mathrm{M}$ annual revenue plus $\$ 20 \mathrm{M}$ for sister company that makes water treatment 
Projected Job Growth:

Considering the company's expected market share, the following tables shows the number of additional U.S. jobs created as a result of the projected industry growth to support new nuclear plants.

\begin{tabular}{|c|c|c|c|c|c|c|c|c|c|c|c|c|c|c|}
\hline Category & '09 & '10 & '11 & '12 & $' 13$ & $' 14$ & $' 15$ & ' 16 & '17 & $' 18$ & '19 & '20 & '21 & '22 \\
\hline Manufacturing Trades & 0 & 2 & 15 & 25 & 40 & 0 & & & & & & & & \\
\hline Engineering & 1 & 2 & 3 & 3 & 3 & 0 & & & & & & & & \\
\hline $\mathrm{QA} / \mathrm{QC}$ & 0 & 1 & 3 & 5 & 6 & 0 & & & & & & & & \\
\hline Shipping and Receiving & 0 & 0 & 1 & 2 & 2 & 0 & & & & & & & & \\
\hline Field Support (SU, service, & 0 & & & & & & & & & & & & & \\
\hline training, warranty, etc.) & & & & & & & & & & & & & & \\
\hline Others, define & 0 & 1 & 2 & 2 & 3 & 0 & & & & & & & & \\
\hline
\end{tabular}

Quality Program:

Company A currently maintains a QA program in accordance with 10CFR50 Appendix B or NQA-1 to support the nuclear industry in both U.S. and Canada.

Threshold for Additional Expansion and Lead Time:

Company A stated that the first order for a new nuclear plant would cause U.S. jobs be created.

Incentives and Constraints:

Company A stated that the "U.S. Supply" clause would be required to add U.S. capacity growth and consequent job growth.

Other Issues:

Company sees greater revenue/profit/labor stability for existing employees as part of this initiative. Company A has had discussions on the growth of business in associations such as TEMA related to the nuclear industry. However, this is not a priority for the organization. 


\section{Survey Results-Company B}

Current Employment:

Current employment level of the company's manufacturing business. Also, the number of jobs located domestically and outside the U.S. and the percentage of employees who have current or past nuclear experience.

Company B has current employee level of 58 with breakdown per the table below:

\begin{tabular}{|l|c|c|c|}
\hline \multicolumn{1}{|c|}{ Category } & $\begin{array}{c}\text { Current } \\
\text { Employee } \\
\text { Level in U.S. }\end{array}$ & $\begin{array}{c}\text { Number } \\
\text { Outside the } \\
\text { U.S. }\end{array}$ & $\begin{array}{c}\text { \% With } \\
\text { Nuclear } \\
\text { Experience }\end{array}$ \\
\hline Manufacturing Trades & 35 & 0 & $50 \%$ \\
\hline Engineering & 8 & 0 & $75 \%$ \\
\hline QA/QC & 3 & 0 & $100 \%$ \\
\hline Shipping and Receiving & 1 & 0 & $100 \%$ \\
\hline $\begin{array}{l}\text { Field Support (startup, service, training, } \\
\text { warranty, etc.) }\end{array}$ & 1 & 0 & $100 \%$ \\
\hline Others, define & 10 & 1 & $75 \%$ \\
\hline
\end{tabular}

Output, Capacity, and Market Share:

Manufacturing output (e.g., number of units produced annually) at the current employment level and shop load percentage at this production rate. This company's domestic market share and current overseas market share. This company's yearly sales volume and the percentage of this sales volume related to domestic/U.S. production.

20 units per year

$15-20 \%$ U.S. market Share

$50 \%$ of the business is international

$\$ 10 \mathrm{M}$ last year (low), average $\$ 15-17 \mathrm{M}$ per year

$75 \%$ U.S. production 
Projected Job Growth:

Considering the company's expected market share, the following tables shows the number of additional U.S. jobs created as a result of the projected industry growth to support new nuclear plants.

\begin{tabular}{|c|c|c|c|c|c|c|c|c|c|c|c|c|}
\hline Category & '09 & '10 & ' 11 & ' 12 & '13 & '14 & '15 & '16 & ' 17 & ' 18 & '19 & 20 \\
\hline Assumed Base Load Plants & & & & & & 1 & 2 & 2 & 2 & 3 & 3 & 4 \\
\hline Manufacturing Trades & 0 & 25 & 50 & 50 & 50 & 75 & 75 & 100 & 100 & 100 & 100 & 100 \\
\hline Engineering & & 1 & 1 & 2 & 2 & 2 & 2 & 2 & 2 & 2 & 2 & 3 \\
\hline $\mathrm{QA} / \mathrm{QC}$ & & 5 & 5 & 5 & 5 & 7 & 7 & 7 & 7 & 7 & 7 & 7 \\
\hline Shipping and Receiving & & 2 & 2 & 1 & 1 & 3 & 3 & 3 & 3 & 3 & 3 & 3 \\
\hline $\begin{array}{l}\text { Field support (SU, service, } \\
\text { training, warranty, etc.) - }\end{array}$ & & 1 & 1 & 2 & 2 & 2 & 2 & 2 & 2 & 2 & 2 & 2 \\
\hline Others, define & & 4 & 4 & 4 & 4 & 5 & 5 & 6 & 6 & 6 & 6 & 6 \\
\hline
\end{tabular}

\section{Quality Program:}

Company B does not currently maintain a QA program in accordance with 10CFR50 Appendix B or NQA-1 to support the nuclear industry. They dropped their program because the volume was too low to maintain their N-stamp.

Threshold for additional Expansion and Lead Time:

Company B stated they will add capacity for the $1^{\text {st }}$ plant build-out.

Incentives and Constraints:

Company B stated that no special incentive would be required to expand their business capacity.

Other Issues:

Company B sees a shortage and high price of raw materials, e.g., carbon steel. Also lead-time for tubing supply is very high (14-30 weeks). Company B also sees benefit from nuclear power expansion such as investment in new machine tool equipment and research and development work. 


\section{Commodity Summary and Indicators}

Two suppliers were surveyed for this commodity. Company A, who claims an $15-20 \%$ market share, projects adding 124 manufacturing jobs to support the nuclear power build-out through 2013.

Company B claims $25 \%$ of the domestic market and projects to add 989 manufacturing jobs through Year 2020.

There are indications that there would be growth in manufacturing jobs, for this sector as well as a sustaining of jobs that will be added to support the current active international market for heat exchangers.

\section{Special Issues}

Companies in this survey expressed a concern over the shortage and high price of raw materials, e.g., carbon steel. Also lead-time for heat exchanger tubing supply is very high. 


\section{Electrical Equipment, Load Centers, MCCs, Switchgear}

\section{Survey Results_Company A}

Current Employment:

Current employment level of the company's manufacturing business. Also, the number of jobs located domestically and outside the U.S. and the percentage of employees who have current or past nuclear experience.

\begin{tabular}{|l|c|c|c|}
\hline \multicolumn{1}{|c|}{ Category } & $\begin{array}{c}\text { Current } \\
\text { Employee } \\
\text { Level }\end{array}$ & $\begin{array}{c}\text { Number } \\
\text { Outside the } \\
\text { U.S. }\end{array}$ & $\begin{array}{c}\text { \% with nuclear } \\
\text { experience }\end{array}$ \\
\hline Manufacturing Trades & 11,200 & 3,961 & $3 \%$ \\
\hline Engineering & 2,300 & 360 & $3 \%$ \\
\hline QA/QC & 410 & 133 & $1 \%$ \\
\hline Shipping and Receiving & N/A & N/A & N/A \\
\hline $\begin{array}{l}\text { Field Support (startup, service, training, } \\
\text { warranty, etc.) }\end{array}$ & 450 & 40 & - \\
\hline $\begin{array}{l}\text { Others, define (sales, supply chain, IT, } \\
\text { HR, admin) }\end{array}$ & 5500 & 259 & $3 \%$ \\
\hline
\end{tabular}

Company A has about 15,000 total manufacturing employees; 4000 are not in the U.S. They have sold off their nuclear service expertise to a European firm, but maintains a close relationship if needed.

Output, Capacity, and Market Share:

Manufacturing output (e.g., number of units produced annually) at the current employment level and shop load percentage at this production rate. This company's domestic market share and current overseas market share. This company's yearly sales volume and the percentage of this sales volume related to domestic/U.S. production.

Company A has $\$ 3$ billion in revenue with shop loading at $80-85 \%$. $\$ 2.3$ billion of revenue is domestic. They have $\sim 100$ manufacturing sites. More than $50 \%$ of business is in North America; depending on product the market share is anywhere from $10-40 \%$. Outside the U.S. the market share range is $0-40 \%$ depending on the country. They do business in over 80 countries. 
Projected Job Growth:

Considering the company's expected market share, the following tables shows the number of additional U.S. jobs created as a result of the projected industry growth to support new nuclear plants.

Company A said that $\$ 300-400$ million incremental increase in sales is predicted for the new NPP quantities posed by the survey. This volume of business does not correlate to an increase in the number of jobs; This conclusion is based on $0-2 \%$ assumed growth for economy. They have roughly a $12 \%$ excess productivity in current domestic capacity. However, should there be a larger than $2 \%$ growth in the economy plus the demand for nuclear plant products, then based on a 7-year growth projection, there would be very modest job growth for Company A (less than 100 people).

Quality Program:

Company A does not maintain a QA program in accordance with 10CFR50 Appendix B or NQA-1 to support the nuclear industry.

Threshold for Additional Expansion and Lead Time:

Company A stated that a $20 \%$ increase in demand would begin the hiring process (not reflected in the nuclear power plant model projections assumed within the survey). The $\$ 400 \mathrm{M}$ available business from new NPPs projected over 20 years does not reach this threshold.

In order to build new capacity they would need to have tax breaks and right to work state. It would take 6 months to add new capacity.

Incentives and Constraints:

Company A stated that they have not outsourced any jobs. Company A sees steel and copper supply and pricing as a constraint to growth.

Other Issues:

Company A said new NPPs would signify political and economic stability in the U.S. Political and economic stability generates growth. Growth benefits everyone. 


\section{Survey Results-Company B}

Current Employment:

Current employment level of the company's manufacturing business. Also, the number of jobs located domestically and outside the U.S. and the percentage of employees who have current or past nuclear experience.

Total of about 100,000 employees. 90,000 are outside the U.S. The percentage with nuclear experience was not available.

Output, Capacity, and Market Share:

Manufacturing output (e.g., number of units produced annually) at the current employment level and shop load percentage at this production rate. This company's domestic market share and current overseas market share. This company's yearly sales volume and the percentage of this sales volume related to domestic/U.S. production.

Company B would not release data on production output or capacity. The sales volume is about $\$ 19 \mathrm{~B}$ per year with $\$ 3.6 \mathrm{~B}$ in U.S. Their market share is about $10 \%$ in the U.S. for medium voltage equipment, more than $40 \%$ in the U.S. for high voltage equipment, and $10-20 \%$ outside the U.S.

Projected Job Growth:

Considering the company's expected market share, the following tables shows the number of additional U.S. jobs created as a result of the projected industry growth to support new nuclear plants.

Company B did not fill out the survey's table. However, they stated that they have excess capacity in their plants now and that they would not add capacity or jobs based on what was presented in the survey (number of nuclear plants per year).

Quality Program:

Company B currently maintains a QA program in accordance with 10CFR50 Appendix B or NQA-1 to support the nuclear industry.

Threshold for Additional Expansion and Lead Time:

Company B stated that this question was not applicable to their situation.

Incentives and Constraints:

Company B did not respond to this question.

Other Issues:

None.

\section{Commodity Summary and Indicators}


Two suppliers were surveyed for this commodity. Despite the tight schedule to respond to the survey, Company A apparently performed a quick 'business case' type of analysis. Company B's response was not as complete. However, the basic result of the two replies are that neither company projected any new job growth as a result of the build-out of new NPPs at the level posed by the survey (and assuming the current economic growth rate of $2-2.5 \% \mathrm{GNP}$ ).

\section{Special Issues}

None.

\section{Data Observations by Bechtel}

None. 


\title{
Survey Results-Company A
}

Current Employment:

Current employment level of the company's manufacturing business. Also, the number of jobs located domestically and outside the U.S. and the percentage of employees who have current or past nuclear experience.

\begin{tabular}{|l|c|c|c|}
\hline \multicolumn{1}{|c|}{ Category } & $\begin{array}{c}\text { Current } \\
\text { Employee } \\
\text { Level }\end{array}$ & $\begin{array}{c}\text { Number } \\
\text { Outside the } \\
\text { U.S. }\end{array}$ & $\begin{array}{c}\text { \% With } \\
\text { Nuclear } \\
\text { Experience }\end{array}$ \\
\hline Manufacturing Trades * & 1076 & 95 & $43 \%$ \\
\hline Engineering & 86 & 10 & $43 \%$ \\
\hline QA/QC & 98 & 11 & $43 \%$ \\
\hline Shipping and Receiving & 100 & 10 & $43 \%$ \\
\hline $\begin{array}{l}\text { Field Support (startup, service, training, } \\
\text { warranty, etc.) }\end{array}$ & See Others & See Others & See Others \\
\hline Others, Procurement \& G\&A & 186 & 8 & $43 \%$ \\
\hline
\end{tabular}

* Includes Pipe Fitters, welders, metal trades

\section{Output, Capacity, and Market Share:}

Manufacturing output (e.g., number of units produced annually) at the current employment level and shop load percentage at this production rate. This company's domestic market share and current overseas market share. This company's yearly sales volume and the percentage of this sales volume related to domestic/U.S. production.

\author{
18,500 spools/month \\ $65 \%$ capacity \\ $50 \%$ domestic market share \\ $5 \%$ overseas market share \\ Yearly Sales Volume is $\$ 260 \mathrm{M}$ with approximately $89 \%$ domestic
}


Projected Job Growth:

Considering the company's expected market share, the following tables shows the number of additional U.S. jobs created as a result of the projected industry growth to support new nuclear plants.

\begin{tabular}{|c|c|c|c|c|c|c|c|c|c|c|c|c|c|c|}
\hline Category & '09 & '10 & ' 11 & $' 12$ & '13 & $' 14$ & ' 15 & $' 16$ & '17 & ' 18 & 19 & '20 & $' 21$ & '22 \\
\hline Manufacturing Trades & 100 & 50 & 50 & 50 & 50 & 50 & 50 & 50 & 50 & 50 & 50 & 50 & 50 & 50 \\
\hline Engineering & 10 & 5 & 5 & 5 & 5 & 5 & 5 & 5 & 5 & 5 & 5 & 5 & 5 & 5 \\
\hline $\mathrm{QA} / \mathrm{QC}$ & 12 & 6 & 6 & 6 & 6 & 6 & 6 & 6 & 6 & 6 & 6 & 6 & 6 & 6 \\
\hline Shipping and Receiving & 10 & 5 & 5 & 5 & 5 & 5 & 5 & 5 & 5 & 5 & 5 & 5 & 5 & 5 \\
\hline $\begin{array}{l}\text { Field Support (SU, service, } \\
\text { training, warranty, etc.) }\end{array}$ & $*$ & $*$ & $*$ & $*$ & $*$ & $*$ & $*$ & $*$ & $*$ & $*$ & $*$ & $*$ & $*$ & $*$ \\
\hline Others, define & 4 & 2 & 2 & 2 & 2 & 2 & 2 & 2 & 2 & 2 & 2 & 2 & 2 & 2 \\
\hline
\end{tabular}

Quality Program:

Company A currently maintains a QA program in accordance with 10CFR50 Appendix B or NQA-1 to support the nuclear industry.

Threshold for Additional Expansion and Lead Time:

Company A stated that the business at the time would determine what threshold of demand for their products would cause U.S. jobs be created to support new nuclear plants. Company A stated that they require less than 1 year of lead-time for the company to make a decision to build new production capacity.

Incentives and Constraints:

Company A stated that they would require 60-day lead time to put new capacity on line. They have mothballed fabrication capacity that can produce 7,500 spools in 90 days. Company A stated that financial incentives would be required to repatriate jobs to the U.S. They also identified the availability of pipe mill capacity to support the demand as a significant constraint to their business.

Other Issues:

Company A saw the potential build-out of new nuclear generation as an incentive for investment in new pipe mill capacity and the development of a skilled/trained workforce. They have also not discussed the issue of job creation in the U.S. within the confines of any of their respective trade associations. 


\section{Survey Results - Company B}

Current Employment:

Current employment level of the company's manufacturing business. Also, the number of jobs located domestically and outside of the U.S. and the percentage of employees that have current or past nuclear experience.

\begin{tabular}{|l|l|l|l|}
\hline \multicolumn{1}{|c|}{ Category } & $\begin{array}{c}\text { Current } \\
\text { Employee } \\
\text { Level }\end{array}$ & $\begin{array}{c}\text { Number } \\
\text { outside the } \\
\text { U.S. }\end{array}$ & $\begin{array}{c}\text { \% With nuclear } \\
\text { experience }\end{array}$ \\
\hline Manufacturing Trades * & 4800 & 600 & 16 \\
\hline Engineering & 94 & 17 & 12 \\
\hline QA/QC & 28 & 16 & 40 \\
\hline Shipping and Receiving & & & \\
\hline $\begin{array}{l}\text { Field support (startup, service, training, } \\
\text { warranty, etc.) }\end{array}$ & & & \\
\hline Others, Procurement \& G\&A & 120 & 30 & 5 \\
\hline
\end{tabular}

* Includes Pipe Fitters, welders, metal trades

Output, Capacity, and Market Share:

Manufacturing output (e.g., number of units produced annually) at the current employment level and shop load percentage at this production rate. This company's domestic market share and current overseas market share. This company's yearly sales volume and the percentage of this sales volume related to domestic/U.S. production.

8,000 Tons

$92 \%$ capacity

$30 \%$ domestic market share

Less than $8 \%$ overseas market share

Yearly Sales Volume is $\$ 600 \mathrm{M}$ with approximately $>90 \%$ domestic 
Projected Job Growth:

Considering the company's expected market share, the following table is the number of additional U.S. jobs created as a result of the projected industry growth to support new nuclear plants.

\begin{tabular}{|c|c|c|c|c|c|c|c|c|c|c|c|c|c|c|}
\hline Category & ‘ 09 & '10 & ' 11 & ' 12 & ' 13 & ' 14 & '15 & '16 & ' 17 & '18 & '19 & 20 & '21 & '22 \\
\hline Manufacturing Trades & 100 & - & - & - & - & - & - & - & - & - & - & - & - & - \\
\hline Engineering & 20 & - & - & - & - & - & - & - & - & - & - & - & - & - \\
\hline $\mathrm{QA} / \mathrm{QC}$ & 12 & - & - & - & - & - & - & - & - & - & - & - & - & - \\
\hline Shipping and Receiving & 0 & - & - & - & - & - & - & - & - & - & - & - & - & - \\
\hline $\begin{array}{l}\text { Field support (SU, service, } \\
\text { training, warranty, etc.) }\end{array}$ & 0 & - & - & - & - & - & - & - & - & - & - & - & - & - \\
\hline Others, define & 0 & - & - & - & - & - & - & - & - & - & - & - & - & - \\
\hline
\end{tabular}

Quality Program:

Company B currently maintains a QA program in accordance with 10CFR50 Appendix B or NQA-1 to support the nuclear industry.

Threshold for additional Expansion and Lead Time:

Company B stated that 30 simultaneous builds is the threshold of demand for their products that would cause U.S. jobs be created to support new nuclear plants. Company B stated that it would be unlikely that they would build new production capacity.

Incentives and Constraints:

Company B stated that a "directive" to add domestic jobs and import tariffs would be required to repatriate jobs to the U.S. They also identified the lack of NCA3800 programs and personnel as a constraint to their business.

Other Issues:

Company B saw the potential build-out of new nuclear generation as an increase in financial resources, increase in technology work base, clean air compliance and reduced dependency on a foreign products as advantages of the nuclear build out. They have also not discussed the issue of job creation in the U.S. within the confines of any of their respective trade associations. 


\section{Commodity Summary and Indicators}

Two suppliers were surveyed for this commodity. Company A claims 50\% market share. They project adding 750 manufacturing jobs and 260 supporting positions during the period of 2009 and 2022 to support the assumed nuclear build out.

Company B claims $30 \%$ of the domestic market and projects to add only 100 manufacturing jobs in 2009 and no more through 2022. In addition, Company B would add 32 support jobs in 2009 as well.

There are strong indications that there would be some moderate growth in manufacturing jobs, for this sector as well as a sustaining of jobs that will have been added to support the current active international market for nuclear quality control valves.

\section{Special Issues}

Company A has a serious concern in the pipe mill capacity in the US.

\section{Data Observations by Bechtel}

The results for these two companies are inconsistent. It would appear that Company B is providing a somewhat conservative projection of job growth through the period. Company $\mathrm{A}$ is also active in the $\mathrm{A} / \mathrm{E} / \mathrm{C}$ nuclear industry and may have better strategic intelligence in the area of impact on job growth. 


\section{Survey Results-Company A}

Current Employment:

Current employment level of the company's manufacturing business. Also, the number of jobs located domestically and outside the U.S. and the percentage of employees who have current or past nuclear experience.

\begin{tabular}{|l|c|c|c|}
\hline \multicolumn{1}{|c|}{ Category } & $\begin{array}{c}\text { Current } \\
\text { Employee } \\
\text { Level in U.S. }\end{array}$ & $\begin{array}{c}\text { Number } \\
\text { Outside the } \\
\text { U.S. }\end{array}$ & $\begin{array}{c}\text { \% With } \\
\text { Nuclear } \\
\text { Experience }\end{array}$ \\
\hline Manufacturing Trades * & 1700 & & $40 \%$ \\
\hline Engineering & 3300 & 100 & NA \\
\hline QA/QC & 80 & & $40 \%$ \\
\hline Shipping and Receiving & In Trades & & NA \\
\hline $\begin{array}{l}\text { Field Support (startup, service, training, } \\
\text { warranty, etc.) }\end{array}$ & 200 & & $4 \%$ \\
\hline Others, Management and G\&A & 200 & & $60 \%$ \\
\hline
\end{tabular}

\begin{tabular}{|l|l|}
\hline$*$ Trade Breakdown by Craft & Multi-trades-200 \\
\hline Fitters \& Welders-300 & Machinists -125 \\
\hline Electricians-100 & Painters-75 \\
\hline Steel Processing-100 & Steel Fabrication-200 \\
\hline Sheet Metal Mech.-175 & Outfitters-475 \\
\hline
\end{tabular}

Output, Capacity, and Market Share:

Manufacturing output (e.g., number of units produced annually) at the current employment level and shop load percentage at this production rate. This company's domestic market share and current overseas market share. This company's yearly sales volume and the percentage of this sales volume related to domestic/U.S. production.

7 to 81200 ton to 1500 ton modules/year $85 \%$ capacity ( 2 full shift plus selected 3 rd shift)

Domestic market share is not definable for this supplier. They have no major business internationally.

Volume -3.5 million job hours are expended per year by this fabricator 
Projected Job Growth:

Considering the company's expected market share, the following tables shows the number of additional U.S. jobs created as a result of the projected industry growth to support new nuclear plants.

\begin{tabular}{|c|c|c|c|c|c|c|c|c|c|c|c|c|c|c|}
\hline Category & '09 & ' 10 & '11 & ' 12 & '13 & ' 14 & ' 15 & ' 16 & '17 & ' 18 & '19 & 20 & 221 & 22 \\
\hline Manufacturing Trades & * & & & & & & & & & & & & & \\
\hline Engineering & * & & & & & & & & & & & & & \\
\hline $\mathrm{QA} / \mathrm{QC}$ & $*$ & & & & & & & & & & & & & \\
\hline Shipping and Receiving & $*$ & & & & & & & & & & & & & \\
\hline $\begin{array}{l}\text { Field Support (SU, service, } \\
\text { training, warranty, etc.) }\end{array}$ & $*$ & & & & & & & & & & & & & \\
\hline Others, define & $*$ & & & & & & & & & & & & & \\
\hline
\end{tabular}

* Company A stated that over the period from 2009 to 2022, they would add 1000 new manufacturing jobs and 125 engineering positions to support the project build-out of new nuclear power plants in the U.S. It should be noted that this company foresees a drop-off in employment from 2005 to 2009 in their market. The jobs they would add to support the nuclear deployment would be new jobs in the 2009 to 2022 time frame.

Quality Program:

Company A currently maintains a QA program in accordance with 10CFR50 Appendix B or NQA-1 to support the nuclear industry. This company does not have an "N" stamp, but does have comparable certification from their major U.S. government customer.

Threshold for Additional Expansion and Lead Time:

Company A stated that they require 24 to 36 months of lead-time for the company to make a decision and build new production capacity.

Incentives and Constraints:

Company A stated that any and all incentives would be helpful to build new manufacturing capacity in the U.S. Also, recruiting and training credits would be required to develop this new workforce. Company A will not be repatriating jobs to the U.S. since their work force is currently domestic. The major constraint expressed by company A was the availability of nuclear related components delivered on time and on budget to their fabrication facility.

Other Issues:

Company A sees sustained profitability and an ability to maintain a core competency to support their primary customer as a key benefit to the deployment of new nuclear plants in the U.S. 


\section{Survey Results-Company B}

A second company in this market segment was contacted and interview by telephone. Company $\mathrm{B}$ did not participate in the survey. They felt that until the government or a customer came to them with a firm business case, that would insure their profit margins, they would not engage in the survey. Company B is not aggressively pursuing the domestic nuclear plant module fabrication market on this basis. 


\section{Commodity Summary and Indicators}

One potential supplier of prefabricated equipment modules was surveyed in this study. There are strong indications that there would be moderate growth in manufacturing jobs estimated at 1000 trade employees over a 14-year period from 2009 through 2022. There would also be growth in engineering positions to support the manufacturing process.

\section{Special Issues}

None Specified

\section{Data Observations by Bechtel}

Company A, although not able to define the market share for their product, is regarded by Bechtel as the leading company in the U.S. to support prefabricated equipment modules for the domestic nuclear market. They are a strong company, and have an active interest, capabilities in people, and capacity to the produce quality and quantity of modules required for a portion of this rebirth. 


\section{Survey Results-Company A}

Current Employment:

Current employment level of the company's manufacturing business. Also, the number of jobs located domestically and outside the U.S. and the percentage of employees who have current or past nuclear experience.

Company A stated they have a total of 4492 employees worldwide of which 3966 are outside the U.S. (a breakdown was not available). Finance, Project Management, Sales, Human Resources, and Contracts Management were the breakdown of employees in the "other" category.

\begin{tabular}{|l|c|c|c|}
\hline \multicolumn{1}{|c|}{ Category } & $\begin{array}{c}\text { Current } \\
\text { Employee } \\
\text { Level in U.S. }\end{array}$ & $\begin{array}{c}\text { Number } \\
\text { Outside the } \\
\text { U.S. }\end{array}$ & $\begin{array}{c}\text { \% With } \\
\text { Nuclear } \\
\text { Experience }\end{array}$ \\
\hline Manufacturing Trades & 215 & Not Available & $20 \%$ \\
\hline Engineering & 81 & & $20 \%$ \\
\hline QA/QC & 9 & & $20 \%$ \\
\hline Shipping and Receiving & 8 & & $20 \%$ \\
\hline $\begin{array}{l}\text { Field Support (startup, service, training, } \\
\text { warranty, etc.) }\end{array}$ & 7 & & $20 \%$ \\
\hline Others, define & 206 & & $20 \%$ \\
\hline
\end{tabular}

Output, Capacity, and Market Share:

Manufacturing output (e.g., number of units produced annually) at the current employment level and shop load percentage at this production rate. This company's domestic market share and current overseas market share. This company's yearly sales volume and the percentage of this sales volume related to domestic/U.S. production.

Entire pump division $\$ 568$ Million. U.S. market is $8 \%$ or $\$ 45$ Million.

$85 \%$ capacity

8 to $10 \%$ domestic market share dependent upon division (power is quoted) 
Projected Job Growth:

Considering the company's expected market share, the following tables shows the number of additional U.S. jobs created as a result of the projected industry growth to support new nuclear plants.

\begin{tabular}{|c|c|c|c|c|c|c|c|c|c|c|c|c|c|c|}
\hline Category & '09 & '10 & ‘11 & '12 & $' 13$ & $' 14$ & ' 15 & ‘ 16 & '17 & $' 18$ & '19 & '20 & '21 & '22 \\
\hline Manufacturing Trades & & 3 & 3 & 12 & 9 & 3 & & 10 & & 7 & & & & \\
\hline Engineering & 6 & 5 & 3 & 2 & 2 & & 2 & & & & & & & \\
\hline $\mathrm{QA} / \mathrm{QC}$ & 2 & 2 & 2 & 1 & 1 & & & & & & & & & \\
\hline Shipping and Receiving & & 2 & 2 & 1 & & 1 & & & & & & & & \\
\hline $\begin{array}{l}\text { Field Support (SU, service, } \\
\text { training, warranty, etc.) }\end{array}$ & & & & & 1 & 2 & 1 & 1 & 1 & & & & & \\
\hline Others, define & 7 & 7 & 6 & 6 & 7 & & 1 & & & & & & & \\
\hline
\end{tabular}

* Company A stated there would be approximately 30 -50 large pumps required. Their share was assumed to be 9 15 pumps.

Quality Program:

Company A currently maintains a QA program in accordance with 10CFR50 Appendix B or NQA-1 to support the nuclear industry in both U.S. and Canada.

Threshold for Additional Expansion and Lead Time:

Company A stated that the first order for a new nuclear plant would cause U.S. jobs be created. Company A maintains their N stamp for repair/ services work.

Incentives and Constraints:

Company A stated that a firm demand for nuclear power plants along with low interest loan incentives would be required to build new manufacturing capacity in the U.S. and that 3 to 5 years of lead-time is needed to make this decision. Company A stated a competitive supply base would be required to repatriate jobs to the U.S. Vendors need to be competitive with overseas suppliers. Company A stated that N-stamp quality castings would be a problem with this demand (it already is).

Other Issues:

Company A saw typical benefits of nuclear power, including reduced plant emissions, stable base load of energy, lower prices and demand for other fuels. They believe that public attitude toward nuclear power will be an obstacle. They have also not discussed the issue of job creation in the U.S. within the confines of any of their respective trade associations. 


\section{Survey Results-Company B}

Current Employment:

Current employment level of the company's manufacturing business. Also, the number of jobs located domestically and outside the U.S. and the percentage of employees who have current or past nuclear experience.

Company B out-sources some of its work to other companies.

\begin{tabular}{|l|c|c|c|}
\hline \multicolumn{1}{|c|}{ Category } & $\begin{array}{c}\text { Current } \\
\text { Employee } \\
\text { Level in U.S. }\end{array}$ & $\begin{array}{c}\text { Number } \\
\text { Outside the } \\
\text { U.S. }\end{array}$ & $\begin{array}{c}\text { \% With } \\
\text { Nuclear } \\
\text { Experience }\end{array}$ \\
\hline Manufacturing Trades * & 450 & 40 & $0 \%$ \\
\hline Engineering & 55 & 8 & $2 \%$ \\
\hline QA/QC & 25 & 4 & $1 \%$ \\
\hline Shipping and Receiving & 20 & 10 & $0 \%$ \\
\hline $\begin{array}{l}\text { Field Support (startup, service, training, } \\
\text { warranty, etc.) }\end{array}$ & 40 & 20 & $0 \%$ \\
\hline Others, define & $800++$ & 100 & $0 \%$ \\
\hline
\end{tabular}

++ office and non-manufacturing

Output, Capacity, and Market Share:

Manufacturing output (e.g., number of units produced annually) at the current employment level and shop load percentage at this production rate. This company's domestic market share and current overseas market share. This company's yearly sales volume and the percentage of this sales volume related to domestic/U.S. production.

Company B stated that workforce is adjusted rapidly in response to demand.

12,000 units per year 3 to $200 \mathrm{Hp}$

$80-90 \%$ capacity at all times

$25 \%$ domestic market share

$10 \%$ overseas market share

$\$ 500 \mathrm{M}$ worldwide sales revenue

$\$ 400 \mathrm{M}$ domestic sales 
Projected Job Growth:

Considering the company's expected market share, the following tables shows the number of additional U.S. jobs created as a result of the projected industry growth to support new nuclear plants.

\begin{tabular}{|c|c|c|c|c|c|c|c|c|c|c|c|c|c|c|}
\hline Category & ‘ 09 & '10 & ' 11 & '12 & '13 & ‘14 & ‘15 & '16 & '17 & ' 18 & '19 & '20 & 21 & '22 \\
\hline \multicolumn{15}{|c|}{ Manufacturing Trades - Note 1} \\
\hline \multicolumn{15}{|l|}{ Engineering - Note 2} \\
\hline \multicolumn{15}{|l|}{ QA/QC - Note 3} \\
\hline Shipping and Receiving & 0 & 0 & 0 & 0 & 0 & 0 & 0 & 0 & 0 & 0 & 0 & 0 & 0 & 0 \\
\hline \multicolumn{15}{|c|}{$\begin{array}{l}\text { Field Support (SU, service, } \\
\text { training, warranty, etc.) - Note } \\
\mathbf{4}\end{array}$} \\
\hline Others, define & 0 & 0 & 0 & 0 & 0 & 0 & 0 & 0 & 0 & 0 & 0 & 0 & 0 & 0 \\
\hline
\end{tabular}

Note 1: 2 to 10 total additions over a 20 -year period depending on volume

Note 2: 1 or 2 employees total

Note 3: 4 to 6 employees total

Note 4: 1 or 2 employees total

Quality Program:

Company B does not currently maintain a QA program in accordance with 10CFR50 Appendix B or NQA-1 to support the nuclear industry. They dropped their program because the volume was too low to maintain their N-stamp. They now use an alternate company to do commercial grade dedication for their parts supplied to the nuclear industry.

Threshold for Additional Expansion and Lead Time:

Company B saw very little impact unless a firm commitment to a full build-out is evident. At that time, they would revisit their corporate strategy.

Incentives and Constraints:

Company B stated that a balanced scope between vendors would provide incentives. Repatriating their workforce does not apply since they have a small workforce overseas. Company B also has a serious concern in foundry capability and quality in the U.S. Overseas foundries have better technology than the U.S. In addition, Company B stated that schedule lengths and payment terms are a concern for nuclear work because companies would be required to carry finance charges for a longer period before payment on nuclear work.

Other Issues:

Company B saw a benefit from less reliance on overseas oil due to potential build-out of new nuclear generation. They have not discussed the issue of job creation in the U.S. within the confines of any of their respective trade associations. 


\section{Survey Results-Company C}

Current Employment:

Current employment level of the company's manufacturing business. Also, the number of jobs located domestically and outside the U.S. and the percentage of employees who have current or past nuclear experience.

Company $\mathrm{C}$ has total of 13,000 employees world-wide with approximately 7,000 employees in the pump division. The table below provides the current employment level of the company's manufacturing business associated with nuclear business line. Also, the number of jobs located domestically and outside the U.S. and the percentage of employees who have current or past nuclear experience.

\begin{tabular}{|l|c|c|c|}
\hline \multicolumn{1}{|c|}{ Category } & $\begin{array}{c}\text { Current } \\
\text { Employee } \\
\text { Level in U.S. }\end{array}$ & $\begin{array}{c}\text { Number } \\
\text { Outside the } \\
\text { U.S. }\end{array}$ & $\begin{array}{c}\text { \% With } \\
\text { Nuclear } \\
\text { Experience }\end{array}$ \\
\hline Manufacturing Trades & 70 & 0 & 80 \\
\hline Engineering & 20 & 0 & 75 \\
\hline QA/QC & 12 & 0 & 80 \\
\hline Shipping and Receiving & 6 & 0 & 75 \\
\hline $\begin{array}{l}\text { Field Support (startup, service, training, } \\
\text { warranty, etc.) }\end{array}$ & 15 & 0 & 100 \\
\hline Others, define & 15 & 0 & 100 \\
\hline
\end{tabular}

Output, Capacity, and Market Share:

Manufacturing output (e.g., number of units produced annually) at the current employment level and shop load percentage at this production rate. This company's domestic market share and current overseas market share. This company's yearly sales volume and the percentage of this sales volume related to domestic/U.S. production.

In U.S. \$65M/year. \$1.3B/year total.

$15 \%$ capacity

$50 \%$ domestic market share

$20 \%$ overseas market share 
Projected Job Growth:

Considering the company's expected market share, the following tables shows the number of additional U.S. jobs created as a result of the projected industry growth to support new nuclear plants.

\begin{tabular}{|c|c|c|c|c|c|c|c|c|c|c|c|c|c|c|}
\hline Category & '09 & '10 & ' 11 & 12 & '13 & '14 & $' 15$ & $' 16$ & '17 & '18 & '19 & '20 & $' 21$ & 22 \\
\hline Manufacturing Trades & 20 & 5 & 5 & 0 & & & & & & & & & & \\
\hline Engineering & 8 & 2 & 0 & 0 & & & & & & & & & & \\
\hline $\mathrm{QA} / \mathrm{QC}$ & 4 & 0 & 0 & 0 & & & & & & & & & & \\
\hline Shipping and Receiving & 2 & 0 & 0 & 0 & & & & & & & & & & \\
\hline Field Support (SU, service, & 5 & 0 & 0 & 0 & & & & & & & & & & \\
\hline training, warranty, etc.) & & & & & & & & & & & & & & \\
\hline Others, define & 2 & 0 & 0 & 0 & & & & & & & & & & \\
\hline
\end{tabular}

Quality Program:

Company C currently maintains a QA program in accordance with 10CFR50 Appendix B or NQA-1 to support the nuclear industry.

Threshold for Additional Expansion and Lead Time:

Company $\mathrm{C}$ stated that addition of one new plant will initiate the job growth. Company $\mathrm{C}$ stated that they require no lead-time for the company to make a decision to build new production capacity; however, they will need 6 months to employ qualified people.

Incentives and Constraints:

Company $\mathrm{C}$ stated that no new manufacturing capacity is needed to support demand, just additional people. However, in order to compete with labor rates that are lower overseas, a 25\% incentive should be offered to domestic manufacturers using U.S. labor and materials.

Other Issues:

Company $\mathrm{C}$ sees that there is a shortage of U.S. qualified casting houses for large components, and they are at a price disadvantage of about $20 \%$ compared to overseas suppliers. 


\section{Survey Results-Company D}

Current Employment:

Current employment level of the company's manufacturing business. Also, the number of jobs located domestically and outside the U.S. and the percentage of employees who have current or past nuclear experience.

\begin{tabular}{|l|c|c|c|}
\hline \multicolumn{1}{|c|}{ Category } & $\begin{array}{c}\text { Current } \\
\text { Employee } \\
\text { Level in U.S. }\end{array}$ & $\begin{array}{c}\text { Number } \\
\text { Outside the } \\
\text { U.S. }\end{array}$ & $\begin{array}{c}\text { \% With } \\
\text { Nuclear } \\
\text { Experience }\end{array}$ \\
\hline Manufacturing Trades & 440 & 550 & $46 \%$ \\
\hline Engineering & 94 & 142 & $49 \%$ \\
\hline QA/QC & 21 & 41 & $32 \%$ \\
\hline Shipping and Receiving & 12 & 16 & $11 \%$ \\
\hline $\begin{array}{l}\text { Field Support (startup, service, training, } \\
\text { warranty, etc.) }\end{array}$ & 17 & 25 & $24 \%$ \\
\hline Others, projects/finance & 183 & 230 & $5 \%$ \\
\hline
\end{tabular}

Output, Capacity, and Market Share:

Manufacturing output (e.g., number of units produced annually) at the current employment level and shop load percentage at this production rate. This company's domestic market share and current overseas market share. This company's yearly sales volume and the percentage of this sales volume related to domestic/U.S. production.

$\$ 530$ Million. U.S. market is 55\%.

75 to $85 \%$ capacity

30 to $45 \%$ domestic market share 
Projected Job Growth:

Considering the company's expected market share, the following tables shows the number of additional U.S. jobs created as a result of the projected industry growth to support new nuclear plants.

\begin{tabular}{|c|c|c|c|c|c|c|c|c|c|c|c|c|c|c|}
\hline Category & 69 & ' 10 & ‘11 & ' 12 & '13 & ' 14 & ' 15 & ' 16 & '17 & ' 18 & '19 & 20 & 221 & 22 \\
\hline Manufacturing Trades & 10 & & 10 & & & & & & & & & & & \\
\hline Engineering & 15 & & & & & & & & & & & & & \\
\hline QA/QC & 5 & & 5 & & & & & & & & & & & \\
\hline Shipping and Receiving & 2 & & & & & & & & & & & & & \\
\hline $\begin{array}{l}\text { Field Support (SU, service, } \\
\text { training, warranty, etc.) }\end{array}$ & 5 & & & & & & & & & & & & & \\
\hline Others, projects & 3 & & & & & & & & & & & & & \\
\hline
\end{tabular}

\section{Quality Program:}

Company D currently maintains a QA program in accordance with 10CFR50 Appendix B or NQA-1 to support the nuclear industry in both U.S continuously since 1977.

Threshold for Additional Expansion and Lead Time:

Company D stated that the order for two new nuclear plants would cause U.S. jobs be created.

Incentives and Constraints:

Company D stated that a guarantee of order placement would be needed to make a decision to expand and 18 to 24 months is required for that decision. Company D stated that job security, relocation costs and financial incentives would be required to repatriate jobs to the U.S. Vendors need to be competitive with overseas suppliers. Company D stated that the limited competition between U.S. suppliers is a concern.

Other Issues:

Company D saw benefits in identifying to the world market that nuclear is needed and safe. They have not discussed the issue of job creation in the U.S. within the confines of any of their respective trade associations. 


\section{Commodity Summary and Indicators}

Four suppliers were surveyed for this commodity. Company A, who claims an 8 to $10 \%$ market share, projects adding 121 manufacturing jobs to support the nuclear power build-out through 2018.

Company B claims $25 \%$ of the domestic market and projects to add 46 to 210 manufacturing jobs between 2009 and 2024 dependent upon the deployment of new nuclear facilities in the U.S.

Company $\mathrm{C}$, who claims and 50\% market share, projects adding 53 manufacturing jobs to support the nuclear power build-out through 2011.

Company D claims 30 to $45 \%$ of the domestic market and projects to add 55 manufacturing jobs between 2009 and 2011.

There are indications that there would be growth in manufacturing jobs, for this sector as well as a sustaining of jobs that will have been added to support the current active international market for pumps.

\section{Special Issues}

Companies in this survey have expressed concern over the casting and foundry capability. In addition, they have serious doubts that U.S. suppliers can compete with overseas suppliers both from a cost and technological standpoint.

\section{Data Observations by Bechtel}

The companies in this survey have overstated their market share as the total for the four companies is more than $100 \%$ of the domestic share. Any data manipulation should take this into account. 


\section{Reactor Vessels and Large Components}

\section{Survey Results-Company A}

Current Employment:

Current employment level of the company's manufacturing business. Also, the number of jobs located domestically and outside the U.S. and the percentage of employees who have current or past nuclear experience.

Company A has approximately 6000 U.S. employees. Company A's parent company has over 30,000 employees and is located outside the U.S. Approximately 30-50\% of the U.S. workforce has nuclear experience and $50 \%$ of the worldwide workforce has nuclear experience.

Output, Capacity, and Market Share:

Manufacturing output (e.g., number of units produced annually) at the current employment level and shop load percentage at this production rate. This company's domestic market share and current overseas market share. This company's yearly sales volume and the percentage of this sales volume related to domestic/U.S. production.

Company A's domestic market share is $35 \%$. The worldwide market share is approximately $25 \%$. Annual sales volume is $\$ 8 \mathrm{~B}$ to $\$ 9 \mathrm{~B}$ of which $30 \%$ is in the U.S. The other questions listed above were not answered. 
Projected Job Growth:

Considering the company's expected market share, the following tables shows the number of additional U.S. jobs created as a result of the projected industry growth to support new nuclear plants.

\begin{tabular}{|c|c|c|c|c|c|c|c|c|c|c|c|c|c|c|}
\hline Category & '09 & '10 & ‘11 & '12 & '13 & '14 & ' 15 & '16 & ‘ 17 & '18 & '19 & $‘^{20}$ & '21 & '22 \\
\hline Manufacturing Trades & $*$ & & & & & & & & & & & & & \\
\hline Engineering & $*$ & & & & & & & & & & & & & \\
\hline $\mathrm{QA} / \mathrm{QC}$ & $*$ & & & & & & & & & & & & & \\
\hline Shipping and Receiving & $*$ & & & & & & & & & & & & & \\
\hline $\begin{array}{l}\text { Field Support (SU, service, } \\
\text { training, warranty, etc.) }\end{array}$ & $*$ & & & & & & & & & & & & & \\
\hline Others, define & $*$ & & & & & & & & & & & & & \\
\hline
\end{tabular}

* Company A stated that they did not believe the nuclear resurgence will be so robust as to require additional manufacturing capacity. In fact, Company A believes that new NPPs would result in a displacement scenario where the large nuclear units $(900-1500 \mathrm{MW})$ would displace the smaller fossil fueled capacity. Other factors would have to change such as the historical load growth and GNP growth at a level exceeding the current 2-2.5 annual percentage increase before Company A would envision new job growth.

Quality Program:

Company A currently maintains a QA program in accordance with 10CFR50 Appendix B or NQA-1 or other similar QA/ISO certification.

Threshold for Additional Expansion and Lead Time:

Company A stated that these questions are not applicable to their situation as they do not project job growth or facility expansion.

Incentives and Constraints:

Company A stated that if they were build new capacity in the U.S. they would need firm evidence of committed orders and a firm idea of their revenue streams. Government requirements for local content would be needed to ensure jobs would be repatriated to the U.S.

Other Issues:

Company A saw benefits such as security of the U.S. electrical energy supply and associated air quality improvements by the build - out of new NPPs. 


\section{Survey Results-Company B}

Current Employment:

Current employment level of the company's manufacturing business. Also, the number of jobs located domestically and outside the U.S. and the percentage of employees who have current or past nuclear experience.

Company B did not provide this information.

Output, Capacity, and Market Share:

Manufacturing output (e.g., number of units produced annually) at the current employment level and shop load percentage at this production rate. This company's domestic market share and current overseas market share. This company's yearly sales volume and the percentage of this sales volume related to domestic/U.S. production.

Company B did not provide this information.

Projected Job Growth:

Considering the company's expected market share, the following tables shows the number of additional U.S. jobs created as a result of the projected industry growth to support new nuclear plants.

\begin{tabular}{|c|c|c|c|c|c|c|c|c|c|c|c|c|c|c|}
\hline Category & ‘09 & '10 & '11 & 12 & '13 & '14 & '15 & ' 16 & '17 & ‘ 18 & '19 & '20 & '21 & '22 \\
\hline Manufacturing Trades & * & & & & & & & & & & & & & \\
\hline Engineering & $*$ & & & & & & & & & & & & & \\
\hline $\mathrm{QA} / \mathrm{QC}$ & $*$ & & & & & & & & & & & & & \\
\hline Shipping and Receiving & $*$ & & & & & & & & & & & & & \\
\hline $\begin{array}{l}\text { Field Support (SU, service, } \\
\text { training, warranty, etc.) }\end{array}$ & * & & & & & & & & & & & & & \\
\hline Others Sales \& G\&A & * & & & & & & & & & & & & & \\
\hline \multicolumn{15}{|c|}{$\begin{array}{l}\text { *Company B did not provide this information. Company B is a U.S. company that was } \\
\text { formerly a major participant in the NPP business in the U.S. As of today they have no plans } \\
\text { to reenter the commercial NPP business. In the U.S. today they manufacture packaged } \\
\text { boilers, utility boilers, soot blowers, wet and dry FGD systems, and process recovery boilers. } \\
\text { They have one shop in the U.S. A sister company has a shop in North America that } \\
\text { manufactures large components for NPPs and is servicing the current operating fleet of } \\
\text { plants. }\end{array}$} \\
\hline
\end{tabular}


Quality Program:

Company B does not maintain a QA program in accordance with 10CFR50 Appendix B or NQA-1 to support the nuclear industry. This qualification was dropped due to the lack of business.

Threshold for Additional Expansion and Lead Time:

Company B stated they have no plan to reenter the U.S. commercial NPP business. However, it would take them several years to build new capacity in the U.S.

Incentives and Constraints:

Company B stated they have no plan to reenter the U.S. commercial NPP business and made no comment; however, they mentioned that there are only two or three heavy wall nuclear grade pipe suppliers and lead times can be well over 1 year.

Other Issues:

Company B saw a benefit of less dependence on foreign energy sources and cheaper power. They said new U.S. NPPs would help make the U.S. competitive again. 


\section{Survey Results-Company C}

Current Employment:

Current employment level of the company's manufacturing business. Also, the number of jobs located domestically and outside the U.S. and the percentage of employees who have current or past nuclear experience.

\begin{tabular}{|l|c|c|c|}
\hline \multicolumn{1}{|c|}{ Category } & $\begin{array}{c}\text { Current } \\
\text { Employee } \\
\text { Level }\end{array}$ & $\begin{array}{c}\text { Number } \\
\text { Outside the U.S. }\end{array}$ & $\begin{array}{c}\text { \% with } \\
\text { nuclear } \\
\text { experience }\end{array}$ \\
\hline Manufacturing Trades & N/A & $1500[* \mathrm{a}]$ & $40 \%$ \\
\hline Engineering & 1 & 1200 & $70 \%$ \\
\hline QA/QC & N/A & $350[* \mathrm{~b}]$ & $70 \%$ \\
\hline Shipping and Receiving & N/A & $\begin{array}{c}\text { Included in [*b] } \\
\text { above }\end{array}$ & $\begin{array}{c}\text { Included in } \\
{[* \mathrm{~b}] \text { above }}\end{array}$ \\
\hline $\begin{array}{l}\text { Field Support (startup, service, training, }[* \mathrm{a}] \\
\text { warranty, etc.) }\end{array}$ & $\begin{array}{c}\text { Included in } \\
{[* \mathrm{a}] \text { above }}\end{array}$ \\
\hline Others, define & N/A & $\begin{array}{c}50 \\
{[\text { Procurement }]}\end{array}$ & $50 \%$ \\
\hline
\end{tabular}

Company $\mathrm{C}$ in not a U.S. company. The numbers in the above table represent employees who are involved in NPP support and are primarily outside the U.S. The approximate number of employees worldwide is 326,000 including all subsidiaries.

Output, Capacity, and Market Share:

Manufacturing output (e.g., number of units produced annually) at the current employment level and shop load percentage at this production rate. This company's domestic market share and current overseas market share. This company's yearly sales volume and the percentage of this sales volume related to domestic/U.S. production.

Company $\mathrm{C}$ said they manufacture approximately $1 \mathrm{RPV}$ each 2 years. Company $\mathrm{C}$ said they manufacture approximately 1 turbine generator set each year. They said their current market share outside the U.S. is $100 \%$ and $0 \%$ in the U.S. Company C's sales volume is $\$ 1.8 \mathrm{~B}$ to $\$ 1.9 \mathrm{~B}$ with none in the U.S. 
Projected Job Growth:

Considering the company's expected market share, the following tables shows the number of additional U.S. jobs created as a result of the projected industry growth to support new nuclear plants.

\begin{tabular}{|l|c|c|c|c|c|c|c|c|c|c|c|c|c|c|}
\hline \multicolumn{1}{|c|}{ Category } & '09 & '10 & '11 & '12 & '13 & '14 & '15 & '16 & '17 & '18 & '19 & '20 & '21 & '22 \\
\hline Manufacturing Trades & & & & & & & & & & & & & & \\
\hline Engineering & 5 & & 5 & & & & & & & & & & & \\
\hline QA/QC & & & & 3 & & 3 & & & & & & & & \\
\hline Shipping and Receiving & & & & & & & & & & & & & & \\
\hline $\begin{array}{l}\text { Field Support (SU, service, } \\
\text { training, warranty, etc.) }\end{array}$ & & & & & 3 & & & & & & & & & \\
\hline Others Sales \& G\&A & & & & & & & & & & & & & & \\
\hline
\end{tabular}

Company $\mathrm{C}$ said they would create a modest number of jobs in the U.S. to support new U.S. NPPs as shown above.

Quality Program:

Company $\mathrm{C}$ does maintain a QA program in accordance with 10CFR50 Appendix B or NQA-1 to support the nuclear industry.

Threshold for Additional Expansion and Lead Time:

Company $\mathrm{C}$ stated they do not see a distinctive threshold because most of the jobs would not be based in the U.S. It would take Company $\mathrm{C}$ at least 2 or 3 years to build new capacity.

Incentives and Constraints:

Company $\mathrm{C}$ stated they foresee a shortage of nuclear grade product subsuppliers.

Other Issues:

Company $\mathrm{C}$ saw benefits of a revitalization of nuclear human resources, maintaining and developing nuclear related technologies, and a reduction of greenhouse gas emissions. Subsequently, Company $\mathrm{C}$ believes there would be an enhancement of public acceptance of the nuclear industry. 


\section{Survey Results-Company D}

Current Employment:

Current employment level of the company's manufacturing business. Also, the number of jobs located domestically and outside the U.S. and the percentage of employees who have current or past nuclear experience.

Company D is a U.S. company with approximately 2,200 employees supporting their nuclear business line. Almost all of their employees have some sort of nuclear experience. Company D declined to provide a breakdown of the employee categories.

Output, Capacity, and Market Share:

Manufacturing output (e.g., number of units produced annually) at the current employment level and shop load percentage at this production rate. This company's domestic market share and current overseas market share. This company's yearly sales volume and the percentage of this sales volume related to domestic/U.S. production.

Company D declined to provide specific information on output. They indicated that they are operating at near capacity. They declined to provide information on their current market share. The company's yearly sales volume for their parent organization (of which they are one component) is about $\$ 18 \mathrm{~B}$. 
Projected Job Growth:

Considering the company's expected market share, the following tables shows the number of additional U.S. jobs created as a result of the projected industry growth to support new nuclear plants.

Company D declined to provide specific estimates of job growth for build-out of
new NPPs. However, Company D said they would expect to capture $30-50 \%$ of the
market share in the U.S. should there be a significant build-out of NPPs. They said
that undoubtedly, the rebirth of new NPPs would stimulate modest job growth for
their business line. However, in order to predict job growth they would need to see
a firm commitment from the government and utilities to construct plants. Until that
happens they are not in a position to make predictions. Certainly if the industry
actually constructed 15 to 20 plants over 15 years they would predict "moderate"
job growth. They are seeing job growth in the U.S. for their engineering support of
the design work for a new generation of reactor. Company D at one time
manufactured RPVs and large components in the U.S. They no longer do so. They
said that they would look to their current group of overseas suppliers for large
components such as RPVs if there would be a rebirth of the industry. Only after
they saw a large commitment to build new NPPs would they begin to consider
bringing back the manufacture of large components to their shops in the U.S.

Quality Program:

Company D does maintain a QA program in accordance with 10CFR50 Appendix B or NQA-1 to support the nuclear industry.

Threshold for Additional Expansion and Lead Time:

Company D stated they would not consider expansion unless they saw a clear commitment of the industry for new orders at a known build-out rate.

Incentives and Constraints:

Company D did not note any particular constraints. Employee job credits (e.g., by the States) would be an important incentive for job creation.

Other Issues:

Company D said that the industry needs some firm leadership from the government so that the industry has clear direction, so firm commitments can be made, etc., so that companies can make business plans. 


\section{Commodity Summary and Indicators}

Four suppliers responded to the survey for this commodity. Company A sees no growth of U.S. jobs for the build-out of new NPPS since these jobs would most likely simply replace jobs that would otherwise be in support of the fossil business.

Company B was once a major participant in the NPP industry, but has departed. They claim they would not reenter the NPP business

Company C is not a U.S. company. Company C would create a modest amount of jobs (19) to support their U.S. NPP business activities.

Company D is a U.S. company. Company D said they would undoubtedly create modest job growth, but they need to see a firm commitment for new NPPS before they would make any plans to grow or change their business model.

\section{Special Issues}

None.

\section{Data Observations by Bechtel}

The responses by Companies A, B, C, and D did not yield consistent data that can be readily compared and contrasted since Company A is a U.S. company, Company B is no longer in the nuclear business, Company $\mathrm{C}$ is a foreign company, Company $\mathrm{D}$ is a U.S. company but was unwilling to predict specific job growth without first seeing a firm commitment to build new NPPs. 


\section{Survey Results-Company A}

Current Employment:

Current employment level of the company's manufacturing business. Also, the number of jobs located domestically and outside the U.S. and the percentage of employees who have current or past nuclear experience.

\begin{tabular}{|l|c|c|c|}
\hline \multicolumn{1}{|c|}{ Category } & $\begin{array}{c}\text { Current } \\
\text { Employee } \\
\text { Level in U.S. }\end{array}$ & $\begin{array}{c}\text { Number } \\
\text { Outside the } \\
\text { U.S.* }\end{array}$ & $\begin{array}{c}\text { \% With } \\
\text { Nuclear } \\
\text { Experience }\end{array}$ \\
\hline Manufacturing Trades & 700 & 80 & $* *$ \\
\hline Engineering & 125 & 15 & $* *$ \\
\hline QA/QC & 18 & 3 & $* *$ \\
\hline Shipping and Receiving & 12 & 2 & $* *$ \\
\hline $\begin{array}{l}\text { Field Support (startup, service, training, } \\
\text { warranty, etc.) }\end{array}$ & 18 & 3 & $* *$ \\
\hline Others, define & & & \\
\hline
\end{tabular}

- Fabrication Plant in Mexico

- Company A was one of only a handful of fabricators in the U.S. who was able to deliver steel for nuclear plants. Some of the experienced people still remain with the organization, including managers, engineers, and shop people; however, the percentage with nuclear experience was not readily available for this survey.

Output, Capacity, and Market Share:

Manufacturing output (e.g., number of units produced annually) at the current employment level and shop load percentage at this production rate. This company's domestic market share and current overseas market share. This company's yearly sales volume and the percentage of this sales volume related to domestic/U.S. production.

In $\$ 315 \mathrm{M} /$ year total, $95 \%$ domestic

$80 \%$ capacity $(100,000$ tons/year)

$2.5 \%$ domestic market share

Negligible_ overseas market share 
Projected Job Growth:

Considering the company's expected market share, the following tables shows the number of additional U.S. jobs created as a result of the projected industry growth to support new nuclear plants.

\begin{tabular}{|c|c|c|c|c|c|c|c|c|c|c|c|c|c|c|}
\hline Category & ‘09 & ‘ 10 & '11 & 12 & ‘13 & $' 14$ & '15 & '16 & '17 & ' 18 & '19 & '20 & '21 & 22 \\
\hline Manufacturing Trades & 100 & 0 & 0 & 0 & 0 & 100 & 0 & 0 & 0 & 100 & 0 & 0 & 0 & 0 \\
\hline Engineering & 5 & 0 & 0 & 0 & 0 & 5 & 0 & 0 & 0 & 5 & 0 & 0 & 0 & 0 \\
\hline $\mathrm{QA} / \mathrm{QC}$ & 3 & 0 & 0 & 0 & 0 & 3 & 0 & 0 & 0 & 3 & 0 & 0 & 0 & 0 \\
\hline Shipping and Receiving & 2 & 0 & 0 & 0 & 0 & 2 & 0 & 0 & 0 & 2 & 0 & 0 & 0 & 0 \\
\hline $\begin{array}{l}\text { Field Support (SU, service, training, warranty, } \\
\text { etc.) }\end{array}$ & 4 & 0 & 0 & 0 & 0 & 4 & 0 & 0 & 0 & 4 & 0 & 0 & 0 & 0 \\
\hline Others, define & & & & & & & & & & & & & & \\
\hline
\end{tabular}

Quality Program:

Company A currently does not maintains a QA program in accordance with 10CFR50 Appendix B or NQA-1 to support the nuclear industry. Company A allowed it Nuclear QA Manual to lapse based upon a lack of nuclear related business.

Threshold for Additional Expansion and Lead Time:

Company A stated that expansion would be based on plant capacity and shop production reserves at the time new nuclear generation commitments are made. Additional capacity would require 2 to 4 years of lead-time.

Incentives and Constraints:

Company A stated that increase demand for steel, lower tax rates and lower fees/insurance rates for operation would be incentives necessary to build new fabricating facilities and repatriate jobs. They identified material availability and nuclear experience as the primary constraints to meeting the potential demand associated with new nuclear generation

\section{Other Issues:}

Company A saw consistent inexpensive sources of power and additional company revenue and profits (margin) as benefits, other than U.S. job growth to the potential build-out of new nuclear generation. They have also not discussed the issue of job creation in the U.S. within the confines of their trade association (American Institute of Steel Construction-AISC). 


\section{Survey Results-Company B}

Current Employment:

Current employment level of the company's manufacturing business. Also, the number of jobs located domestically and outside the U.S. and the percentage of employees who have current or past nuclear experience.

\begin{tabular}{|l|c|c|c|}
\hline \multicolumn{1}{|c|}{ Category } & $\begin{array}{c}\text { Current } \\
\text { Employee } \\
\text { Level in U.S. }\end{array}$ & $\begin{array}{c}\text { Number } \\
\text { Outside the } \\
\text { U.S. }\end{array}$ & $\begin{array}{c}\text { \% With } \\
\text { Nuclear } \\
\text { Experience }\end{array}$ \\
\hline Manufacturing Trades * & 110 & 0 & 80 \\
\hline Engineering & 7 & 0 & 50 \\
\hline QA/QC & 4 & 0 & 100 \\
\hline Shipping and Receiving & 3 & 0 & 100 \\
\hline $\begin{array}{l}\text { Field Support (startup, service, training, } \\
\text { warranty, etc.) }\end{array}$ & 0 & 0 & 0 \\
\hline Others, Sales, G\&A & 0 & 0 & 0 \\
\hline
\end{tabular}

Output, Capacity, and Market Share:

Manufacturing output (e.g., number of units produced annually) at the current employment level and shop load percentage at this production rate. This company's domestic market share and current overseas market share. This company's yearly sales volume and the percentage of this sales volume related to domestic/U.S. production.

In $\$ 20 \mathrm{M} /$ year total, all domestic

$80 \%$ capacity $(12,000$ tons/year)

$0.5 \%$ domestic market share

No overseas market share 
Projected Job Growth:

Considering the company's expected market share, the following tables shows the number of additional U.S. jobs created as a result of the projected industry growth to support new nuclear plants.

\begin{tabular}{|c|c|c|c|c|c|c|c|c|c|c|c|c|c|c|}
\hline Category & ‘09 & '10 & '11 & '12 & '13 & '14 & '15 & '16 & ‘17 & '18 & ‘19 & 20 & 21 & 22 \\
\hline Manufacturing Trades & 35 & 55 & 90 & 35 & 55 & 35 & 55 & 90 & 35 & 55 & 0 & 0 & 0 & 0 \\
\hline Engineering & 2 & 3 & 4 & 2 & 3 & 2 & 3 & 4 & 2 & 3 & 0 & 0 & 0 & 0 \\
\hline QA/QC & 2 & 0 & 2 & 0 & 0 & 2 & 0 & 2 & 0 & 0 & 0 & 0 & 0 & 0 \\
\hline Shipping and Receiving & 2 & 0 & 2 & 2 & 2 & 2 & 0 & 2 & 2 & 2 & 0 & 0 & 0 & 0 \\
\hline $\begin{array}{l}\text { Field Support (SU, service, } \\
\text { training, warranty, etc.) }\end{array}$ & 0 & 0 & 0 & 0 & 0 & 0 & 0 & 0 & 0 & 0 & 0 & 0 & 0 & 0 \\
\hline Others Sales \& G\&A & 0 & 0 & 0 & 0 & 0 & 0 & 0 & 0 & 0 & 0 & 0 & 0 & 0 & 0 \\
\hline
\end{tabular}

Quality Program:

Company B currently maintains a QA program in accordance with 10CFR50 Appendix B or NQA-1 to support the nuclear industry. Company B is currently supplying steel at the DOE Hanford Site.

Threshold for Additional Expansion and Lead Time:

Company B stated they would add job immediately upon receipt of the first plant order based on their current capacity and shop load. To add additional capacity, fabrication facilities would require an 8-to-12-month lead time for personnel and a 2-year lead time for the actual facilities.

Incentives and Constraints:

Company B stated that low cost government loans for plant construction, government subsides for training employees and assurances that investments made for the nuclear program could be recovered in during the lifespan of the program would be necessary incentives to build new fabrication facilities. Company B indicated that a new fabrication facility for a 150,000 square foot plant would cost approximately $\$ 8 \mathrm{M}$ to $\$ 10 \mathrm{M}$. Company B expressed concerns that subsuppliers would have the same issues and/or concerns as they have. Specifically addressing the need to add capacity and personnel to meet the demand. Company B also highlight a concern related to flow down of contract requirements to their subsuppliers based on current practices at Hanford. Many of the requirements and the volume of regulations are overwhelming for subsuppliers.

Other Issues:

Company B saw greater profit margins and less dependence on imported oil as benefits resulting from the potential build-out of new nuclear generation. They have also not discussed the issue of job creation in the U.S. within the confines of their trade association (American Institute of Steel Construction - AISC).

\section{Commodity Summary and Indicators}


Based on input received from the AISC, U.S. mills are capable of producing 6,000,000 tons of structural steel annually and currently are at a manufacturing 4,000,000 tons annually. It has been estimated that new nuclear generation would require 500,000 to 750,000 tons over a 10 year period. This potential demand represents approximately $4 \%$ of the existing reserve capacity available in the U.S. today. Based upon the overall availability of structural steel, this survey focused on the fabrication of steel rather than the manufacturing of structural steel.

The AISC currently has over 600 fabricators listed throughout the world as qualified suppliers under their program, of which, more than $90 \%$ reside in the U.S. Two suppliers were surveyed for this commodity. Combined, these two represent $3 \%$ of the U.S. domestic market share. Combined, they currently fabricate over 100,000 tons annually.

Based on estimates, each new nuclear generating plant would require approximately 20,000 tons of structural steel. This added demand would require additional personnel immediately upon commitments for new plants. The addition of, and number of, new facilities required to meet this demand would depend on the number of fabricator involved through the build-out and the size of the fabricators selected.

\section{Special Issues}

As shown in the survey results above, the lead-time for adding new fabrication facilities is 2 years or more and represents a sizable commitment for any particular fabricator. Both companies surveyed expressed concerns related to finding qualified personnel and training personnel for new nuclear generation plants.

\section{Data Observations by Bechtel}

The two companies surveyed for this report represent a small and a medium to large size fabricator. The projections for new jobs and facilities varied based on the size of the fabricator. Larger fabricators would be in a position to commit to early plant commitments during the buildout without adding facilities. Smaller fabricators, however, would need to add facilities throughout the build-out. 


\section{Survey Results-Company A}

Current Employment:

Current employment level of the company's manufacturing business. Also, the number of jobs located domestically and outside the U.S. and the percentage of employees who have current or past nuclear experience.

\begin{tabular}{|l|c|c|c|}
\hline \multicolumn{1}{|c|}{ Category } & $\begin{array}{c}\text { Current } \\
\text { Employee } \\
\text { Level in U.S. }\end{array}$ & $\begin{array}{c}\text { Number } \\
\text { Outside the } \\
\text { U.S. }\end{array}$ & $\begin{array}{c}\text { \% With } \\
\text { Nuclear } \\
\text { Experience }\end{array}$ \\
\hline Manufacturing Trades * & 7200 & 630 & 4 \\
\hline Engineering & 1200 & 500 & 3 \\
\hline QA/QC & 70 & 25 & 10 \\
\hline Shipping and Receiving & $* *$ & $* *$ & $* *$ \\
\hline $\begin{array}{l}\text { Field Support (startup, service, training, } \\
\text { warranty, etc.) }\end{array}$ & 720 & 360 & 3 \\
\hline Others, define & 550 & 265 & 2 \\
\hline
\end{tabular}

- *Includes shop and field craft labor

- **Includes with Trades

Output, Capacity, and Market Share:

Manufacturing output (e.g., number of units produced annually) at the current employment level and shop load percentage at this production rate. This company's domestic market share and current overseas market share. This company's yearly sales volume and the percentage of this sales volume related to domestic/U.S. production.

In U.S. $\$ 1 \mathrm{~B} /$ year. $\$ 600 \mathrm{M} /$ year outside the U.S.

$65 \%$ capacity ( 800 to 1000 units ranging from $4000-1 \mathrm{M}$ barrel capacity)

$25 \%$ domestic market share

$25 \%$ overseas market share 
Projected Job Growth:

Considering the company's expected market share, the following tables shows the number of additional U.S. jobs created as a result of the projected industry growth to support new nuclear plants.

\begin{tabular}{|c|c|c|c|c|c|c|c|c|c|c|c|c|c|c|}
\hline Category & '09 & ‘ 10 & '11 & $' 12$ & $' 13$ & $' 14$ & '15 & $' 16$ & '17 & '18 & '19 & '20 & $' 21$ & '22 \\
\hline Manufacturing Trades * & 0 & 1 & 5 & 6 & 7 & 9 & 0 & 0 & 0 & 0 & 0 & 0 & 0 & 0 \\
\hline Engineering & 1 & 2 & 2 & 2 & 1 & 0 & 0 & 0 & 0 & 0 & 0 & 0 & 0 & 0 \\
\hline $\mathrm{QA} / \mathrm{QC}$ & 1 & 0 & 1 & 0 & 1 & 0 & 0 & 0 & 0 & 0 & 0 & 0 & 0 & 0 \\
\hline Shipping and Receiving & $* *$ & $* *$ & $* *$ & $* *$ & $* *$ & $* *$ & $* *$ & $* *$ & $* *$ & $* *$ & $* *$ & $* *$ & $* *$ & $* *$ \\
\hline $\begin{array}{l}\text { Field Support (SU, service, } \\
\text { training, warranty, etc.) }\end{array}$ & 1 & 0 & 0 & 1 & 0 & 0 & 0 & 0 & 0 & 0 & 0 & 0 & 0 & 0 \\
\hline Others, define & 1 & 0 & 0 & 0 & 1 & 0 & 0 & 0 & 0 & 0 & 0 & 0 & 0 & 0 \\
\hline
\end{tabular}

- *Includes shop and field craft labor

- **Includes with Trades

Quality Program:

Company A no loner maintains a QA program in accordance with 10CFR50 Appendix B or NQA-1 to support the nuclear industry. They allowed their Nuclear QA Manual to lapse stating that there was no economic justification for keeping it current.

Threshold for Additional Expansion and Lead Time:

Company A stated that they would add positions immediately upon receipt for the first unit. Company A did not foresee the need to add facilities to support the added demand for new nuclear generation.

Incentives and Constraints:

Company A did does not support its domestic market with offshore resources and did not see any need to add facilities therefore no specific incentives were identified. Company A's primary concern with supporting new nuclear generation plants was initially finding and approving subsuppliers and vendors with qualified Nuclear QA programs. Typically, after some period of time the subsuppliers would exist in the market place as a result of other primary market demands (secondary to the tank industry).

\section{Other Issues:}

Company A saw a lesser reliance on fossil fuels as benefits to the potential build-out of new nuclear generation. They have also not discussed the issue of job creation in the U.S. within the confines of any of their respective trade associations (American Water Works Association AWWA and American Petroleum Institute - API). 


\section{Commodity Summary and Indicators}

Only one supplier was surveyed for this commodity. Company A, who claims $25 \%$ market share was key player in the supply of tanks and fabricated plate during the original nuclear plant buildout. Based on the number of tanks fabricated annually, the added demand that new nuclear generation would be insignificant as may be seen from the table above.

\section{Special Issues}

Sourcing of qualified subsuppliers for initial orders. As noted above, subsuppliers for items associated with tanks tend to be qualified for other commodities in the market place first. For example, flange used on tanks would be sourced from the same subsuppliers that would provide flanges to the piping industry. Once they are qualified for pipe supply, then the tank fabricators would relay on the same suppliers.

\section{Data Observations by Bechtel}

For field-erected tanks, the projected job growth would be insignificant as shown above. However, the same fabricator used for tanks would also be involved with supplying other fabricated plate materials (i.e. liner plates), which then would result in measurable job growth. 


\section{Survey Results-Company A}

Current Employment:

Current employment level of the company's manufacturing business. Also, the number of jobs located domestically and outside the U.S. and the percentage of employees who have current or past nuclear experience.

\begin{tabular}{|l|c|c|c|}
\hline \multicolumn{1}{|c|}{ Category } & $\begin{array}{c}\text { Current } \\
\text { Employee } \\
\text { Level in U.S. }\end{array}$ & $\begin{array}{c}\text { Number } \\
\text { Outside the } \\
\text { U.S. }\end{array}$ & $\begin{array}{c}\text { \% With } \\
\text { Nuclear } \\
\text { Experience }\end{array}$ \\
\hline Manufacturing Trades * & 74 & 0 & 25 \\
\hline Engineering & 10 & 0 & 30 \\
\hline QA/QC & 3 & 0 & 66 \\
\hline Shipping and Receiving & 1 & 0 & 100 \\
\hline $\begin{array}{l}\text { Field Support (startup, service, training, } \\
\text { warranty, etc.) }\end{array}$ & 2 & 0 & 100 \\
\hline Others, define & 0 & 0 & 0 \\
\hline
\end{tabular}

Output, Capacity, and Market Share:

Manufacturing output (e.g., number of units produced annually) at the current employment level and shop load percentage at this production rate. This company's domestic market share and current overseas market share. This company's yearly sales volume and the percentage of this sales volume related to domestic/U.S. production.

In U.S. \$12M/year. (1,000 tanks per year)

$100 \%$ capacity (Single Shift)

$5 \%$ domestic market share

$<1 \%$ overseas market share 
Projected Job Growth:

Considering the company's expected market share, the following tables shows the number of additional U.S. jobs created as a result of the projected industry growth to support new nuclear plants.

\begin{tabular}{|c|c|c|c|c|c|c|c|c|c|c|c|c|c|c|}
\hline Category & 69 & ' 10 & ‘ 11 & ' 12 & ‘ 13 & '14 & ‘ 15 & '16 & '17 & '18 & ‘19 & 20 & 21 & 22 \\
\hline Manufacturing Trades & 5 & 5 & 10 & 10 & 5 & 5 & 0 & 0 & 0 & 0 & 0 & 0 & 0 & 0 \\
\hline Engineering & 1 & 1 & 2 & 1 & 1 & 0 & 0 & 0 & 0 & 0 & 0 & 0 & 0 & 0 \\
\hline QA/QC & 1 & 1 & 2 & 1 & 0 & 0 & 0 & 0 & 0 & 0 & 0 & 0 & 0 & 0 \\
\hline Shipping and Receiving & 0 & 0 & 1 & 0 & 0 & 0 & 0 & 0 & 0 & 0 & 0 & 0 & 0 & 0 \\
\hline $\begin{array}{l}\text { Field Support (SU, service, } \\
\text { training, warranty, etc.) }\end{array}$ & 0 & 0 & 0 & 0 & 0 & 0 & 0 & 0 & 0 & 0 & 0 & 0 & 0 & 0 \\
\hline Others, define & 0 & 0 & 0 & 0 & 0 & 0 & 0 & 0 & 0 & 0 & 0 & 0 & 0 & 0 \\
\hline
\end{tabular}

\section{Projected job growth is based upon a forecasted market share of $15 \%$ of the new nuclear generation}

\section{Quality Program:}

Company A no longer maintains a QA program in accordance with 10CFR50 Appendix B or NQA-1 to support the nuclear industry. Company A allowed their nuclear QA Manual to lapse 20 years ago due to a lack of related business.

Threshold for Additional Expansion and Lead Time:

Company A is currently working at $100 \%$ plant capacity (single shift) and would need to add jobs immediately to support work associated with new nuclear generation plant construction. Company A has space and equipment available to work an additional 50 people $\left(2^{\text {nd }}\right.$ Shift) to support this imitative. Company A stated that they require 1 to 2 years of lead-time to make a decision to build new production capacity.

Incentives and Constraints:

Company A stated that confidence in long term nuclear power project work would be an incentive required to build new manufacturing capacity in the U.S. Company A had no known incentives that would be required to repatriate jobs to the U.S, because their current staff and facilities are entirely domestic. As far as constraints, they believe the willingness of subsuppliers to "ramp-up" for nuclear work would be the largest constraint to meet additional demands new nuclear projects.

\section{Other Issues:}

Company A saw lessening dependence on foreign oil, growth in all industry sectors and greater tax revenues as the benefits by the potential build-out of new nuclear generation. They have also not discussed the issue of job creation in the U.S. within the confines of any of their respective trade associations. 


\section{Survey Results-Company B}

Current Employment:

Current employment level of the company's manufacturing business. Also, the number of jobs located domestically and outside the U.S. and the percentage of employees who have current or past nuclear experience.

\begin{tabular}{|l|c|c|c|}
\hline \multicolumn{1}{|c|}{ Category } & $\begin{array}{c}\text { Current } \\
\text { Employee } \\
\text { Level in U.S. }\end{array}$ & $\begin{array}{c}\text { Number } \\
\text { Outside the } \\
\text { U.S. }\end{array}$ & $\begin{array}{c}\text { \% With } \\
\text { Nuclear } \\
\text { Experience }\end{array}$ \\
\hline Manufacturing Trades * & 156 & 0 & $?$ \\
\hline Engineering & 4 & 0 & $?$ \\
\hline QA/QC & 3 & 0 & $?$ \\
\hline Shipping and Receiving & 2 & 0 & $?$ \\
\hline $\begin{array}{l}\text { Field Support (startup, service, training, } \\
\text { warranty, etc.) }\end{array}$ & 0 & 0 & N/A \\
\hline Others, Sales, G\&A & 30 & 0 & $?$ \\
\hline
\end{tabular}

\section{* Company B has not supplied tanks for nuclear application in the past 20 years, therefore the level of remaining nuclear experience was not readily available.}

Output, Capacity, and Market Share:

Manufacturing output (e.g., number of units produced annually) at the current employment level and shop load percentage at this production rate. This company's domestic market share and current overseas market share. This company's yearly sales volume and the percentage of this sales volume related to domestic/U.S. production.

$>5,000$ tanks per year

$100 \%$ capacity

$85 \%$ domestic market share

$15 \%$ overseas market share

\$35M worldwide sales revenue

$\$ 30 \mathrm{M}$ domestic sales volume 
Projected Job Growth:

Considering the company's expected market share, the following tables shows the number of additional U.S. jobs created as a result of the projected industry growth to support new nuclear plants.

\begin{tabular}{|c|c|c|c|c|c|c|c|c|c|c|c|c|c|c|}
\hline Category & ' 09 & ' 10 & '11 & ' 12 & '13 & '14 & '15 & '16 & '17 & '18 & '19 & 20 & 21 & 22 \\
\hline Manufacturing Trades & 10 & 10 & 10 & 10 & 10 & 10 & 10 & 10 & 10 & 10 & 10 & 10 & 10 & 10 \\
\hline Engineering & 1 & 1 & 1 & 1 & 1 & 1 & 1 & 1 & 1 & 1 & 1 & 1 & 1 & 1 \\
\hline QA/QC & 2 & 1 & 1 & 1 & 1 & 1 & 1 & 1 & 1 & 1 & 1 & 1 & 1 & 1 \\
\hline Shipping and Receiving & 2 & 1 & 1 & 1 & 1 & 1 & 1 & 1 & 1 & 1 & 1 & 1 & 1 & 1 \\
\hline $\begin{array}{l}\text { Field Support (SU, service, } \\
\text { training, warranty, etc.) }\end{array}$ & 1 & 1 & 1 & 1 & 1 & 1 & 1 & 1 & 1 & 1 & 1 & 1 & 1 & 1 \\
\hline Others Sales \& G\&A & 5 & 1 & 1 & 1 & 1 & 1 & 1 & 1 & 1 & 1 & 1 & 1 & 1 & 1 \\
\hline
\end{tabular}

Quality Program:

Company B no longer maintains a QA program in accordance with 10CFR50 Appendix B or NQA-1 to support the nuclear industry. They allowed their nuclear QA Manual to lapse 20 years ago based on a lack of nuclear related business.

Threshold for Additional Expansion and Lead Time:

Company B stated they would need to add jobs immediately to support new nuclear generation. Company B stated that they require 2 to 3 years of lead time to build new production capacity.

Incentives and Constraints:

Company B stated that long term contracts or commitments would be a necessary incentive to support new nuclear generation. No incentives would be required to repatriate jobs to the U.S since their staffs and facilities are totally domestic. In Company B's opinion, constraints potentially affecting new nuclear generation would be availability of domestic materials (steel plate) and availability of qualified staffing (manual and non-manual).

Other Issues:

Company B saw environmental benefits due to potential build-out of new nuclear generation. They have also not discussed the issue of job creation in the U.S. within the confines of any of their respective trade associations. 


\section{Commodity Summary and Indicators}

Two suppliers were surveyed for this commodity. Combined these two companies currently manufacture over 6,000 shop fabricated tanks each year. For new nuclear generation it has been estimated that an additional 1,500 to 6,000 tanks would need to be fabricated over a 10-to-15year period. Over this same 10-to-15-year period these two companies would fabricate between 60,000 and 90,000 tanks at their current shop capacity.

Considering both of the companies surveyed were working single shifts, it is unlikely that new nuclear generation would require significant plant capacity improvements. However, the fabrication of shop tanks is labor intensive and job growth would be required immediately in the fabrication sector and may also result in some additional job growth in the steel-manufacturing sector associated with the supply of plate materials.

\section{Special Issues}

Companies will need to develop a level of confidence in long-term nuclear generating project in order to make the necessary commitment to re-establish their Nuclear QA Manuals.

Availability of domestic plate material may become an issue depending on what priority steel mills set on the supply of plate versus structural members.

\section{Data Observations by Bechtel}

Projected job growth for Company B in the Manufacturing Trades is not consistent with the full build-out plan in later years. It is unlikely that Company B would need to continue added trade positions at a rate of 10 per year after 2017. At that point Company B should have adequate staffing in place to keep up with the projected demand. The same observation hold true for all categories for Company B after 2017. 


\section{Turbine Generator Sets}

\section{Survey Results-Company A}

Current Employment:

Current employment level of the company's manufacturing business. Also, the number of jobs located domestically and outside the U.S. and the percentage of employees who have current or past nuclear experience.

Company A has approximately 6500 U.S. employees. Company A's parent company has over 30,000 employees and is located outside the U.S. Approximately 30-50\% of the U.S. workforce has nuclear experience and $50 \%$ of the worldwide workforce has nuclear experience.

Output, Capacity, and Market Share:

Manufacturing output (e.g., number of units produced annually) at the current employment level and shop load percentage at this production rate. This company's domestic market share and current overseas market share. This company's yearly sales volume and the percentage of this sales volume related to domestic/U.S. production.

Company A's domestic market share is $33 \%$. The worldwide market share is approximately $25 \%$. Annual sales volume is $\$ 8 \mathrm{~B}$ to $\$ 9 \mathrm{~B}$ of which $30 \%$ is in the U.S. The other questions listed above were not answered. 
Projected Job Growth:

Considering the company's expected market share, the following tables shows the number of additional U.S. jobs created as a result of the projected industry growth to support new nuclear plants.

\begin{tabular}{|c|c|c|c|c|c|c|c|c|c|c|c|c|c|c|}
\hline Category & '09 & '10 & ‘11 & '12 & '13 & '14 & ' 15 & '16 & ‘ 17 & '18 & '19 & $‘^{20}$ & '21 & '22 \\
\hline Manufacturing Trades & $*$ & & & & & & & & & & & & & \\
\hline Engineering & $*$ & & & & & & & & & & & & & \\
\hline $\mathrm{QA} / \mathrm{QC}$ & $*$ & & & & & & & & & & & & & \\
\hline Shipping and Receiving & $*$ & & & & & & & & & & & & & \\
\hline $\begin{array}{l}\text { Field Support (SU, service, } \\
\text { training, warranty, etc.) }\end{array}$ & $*$ & & & & & & & & & & & & & \\
\hline Others, define & $*$ & & & & & & & & & & & & & \\
\hline
\end{tabular}

* Company A stated that they did not believe the nuclear resurgence will be so robust as to require additional manufacturing capacity. In fact, Company A believes that new NPPs would result in a displacement scenario where the large nuclear units $(900-1500 \mathrm{MW})$ would displace the smaller fossil fueled capacity. Other factors would have to change such as the historical load growth and GNP growth at a level exceeding the current 2-2.5 annual percentage increase before Company A would envision new job growth.

Quality Program:

Company A currently maintains a QA program in accordance with 10CFR50 Appendix B or NQA-1 or other similar QA/ISO certification.

Threshold for Additional Expansion and Lead Time:

Company A stated that these questions are not applicable to their situation, because they do not project job growth or facility expansion.

Incentives and Constraints:

Company A stated that in order to build new capacity in the U.S., they would need firm evidence of new orders and the associated impact on its revenue stream.

Government requirements for local content would be needed to ensure jobs would be repatriated to the U.S.

Other Issues:

Company A noted benefits such as security of the U.S. electrical energy supply and associated air quality improvements in the build -out of new NPPs. 


\section{Survey Results-Company B}

Current Employment:

Current employment level of the company's manufacturing business. Also, the number of jobs located domestically and outside the U.S. and the percentage of employees who have current or past nuclear experience.

\begin{tabular}{|l|c|c|c|}
\hline \multicolumn{1}{|c|}{ Category } & $\begin{array}{c}\text { Current } \\
\text { Employee } \\
\text { Level }\end{array}$ & $\begin{array}{c}\text { Number } \\
\text { Outside the U.S. }\end{array}$ & $\begin{array}{c}\text { \% With } \\
\text { Nuclear } \\
\text { Experience }\end{array}$ \\
\hline Manufacturing Trades & N/A & $1500[* \mathrm{a}]$ & $40 \%$ \\
\hline Engineering & 1 & 1200 & $70 \%$ \\
\hline QA/QC & N/A & $350[* \mathrm{~b}]$ & $70 \%$ \\
\hline Shipping and Receiving & N/A & $\begin{array}{c}\text { Included in }[* \mathrm{~b}] \\
\text { above }\end{array}$ & $\begin{array}{c}\text { Included in } \\
{[* \mathrm{~b}] \text { above }}\end{array}$ \\
\hline $\begin{array}{l}\text { Field Support (startup, service, training }\left[{ }^{*} \mathrm{a}\right] \\
\text { warranty, etc.) }\end{array}$ & $\begin{array}{c}\text { Included in } \\
{[* \mathrm{a}] \text { above }}\end{array}$ \\
\hline Others, define & N/A & $\begin{array}{c}50 \\
{[\text { Procurement }]}\end{array}$ & $50 \%$ \\
\hline
\end{tabular}

Company B in not a U.S. company. The numbers in the above table represent employees who are based outside the U.S. The approximate number of employees worldwide is 326,000 including all subsidiaries.

Output, Capacity, and Market Share:

Manufacturing output (e.g., number of units produced annually) at the current employment level and shop load percentage at this production rate. This company's domestic market share and current overseas market share. This company's yearly sales volume and the percentage of this sales volume related to domestic/U.S. production.

Company B stated that they manufacture approximately 1 turbine generator set each year. They said their current market share outside the U.S. is $100 \%$ and $0 \%$ in the U.S. Company B's sales volume is $\$ 1.8 \mathrm{~B}$ to $\$ 1.9 \mathrm{~B}$ with none in the U.S. 
Projected Job Growth:

Considering the company's expected market share, the following tables shows the number of additional U.S. jobs created as a result of the projected industry growth to support new nuclear plants.

\begin{tabular}{|c|c|c|c|c|c|c|c|c|c|c|c|c|c|c|}
\hline Category & ‘09 & ' 10 & ‘11 & ' 12 & ' 13 & ‘14 & ‘ 15 & ' 16 & '17 & ' 18 & ‘ 19 & 20 & 221 & '22 \\
\hline \multicolumn{15}{|l|}{ Manufacturing Trades } \\
\hline Engineering & 5 & & 5 & & & & & & & & & & & \\
\hline $\mathrm{QA} / \mathrm{QC}$ & & & & 3 & & 3 & & & & & & & & \\
\hline \multicolumn{15}{|l|}{ Shipping and Receiving } \\
\hline $\begin{array}{l}\text { Field Support (SU, service, } \\
\text { training, warranty, etc.) }\end{array}$ & & & & & 3 & & & & & & & & & \\
\hline Others Sales \& G\&A & & & & & & & & & & & & & & \\
\hline
\end{tabular}

Company B said they would create a modest number of jobs in the U.S. to support new U.S. NPPs as shown above.

Quality Program:

Company B does maintain a QA program in accordance with 10CFR50 Appendix B or NQA-1 to support the nuclear industry.

Threshold for Additional Expansion and Lead Time:

Company B stated they do not see a distinctive threshold, because most of the jobs would not be based in the U.S. It would take Company B at least 2 to 3 years to build new capacity.

Incentives and Constraints:

Company B stated they foresee a shortage of nuclear grade product subsuppliers.

Other Issues:

Company B saw benefits in the revitalization of nuclear human resources, maintenance and development of nuclear related technologies, and a reduction in greenhouse gas emissions. Company B believes that there is potential to improve the public acceptance of the nuclear industry. 


\section{Survey Results-Company C}

Current Employment:

Current employment level of the company's manufacturing business. Also, the number of jobs located domestically and outside the U.S. and the percentage of employees who have current or past nuclear experience.

Company $\mathrm{C}$ is a company with approximately 50,000 employees, of which 10,000 are located in the U.S. Approximately 200 of their employees have some sort of nuclear experience. Company $\mathrm{C}$ declined to provide a breakdown of the employee categories.

Output, Capacity, and Market Share:

Manufacturing output (e.g., number of units produced annually) at the current employment level and shop load percentage at this production rate. This company's domestic market share and current overseas market share. This company's yearly sales volume and the percentage of this sales volume related to domestic/U.S. production.

Company C produces 15-20 turbine generator sets per year. They are currently operating at $75 \%$ capacity. Their U.S. market share is $25-30$ percent for new equipment and $50 \%$ in the retrofit business. The company's yearly sales volume is about $\$ 14 \mathrm{~B}$, of which about 4.9B is U.S. 
Projected Job Growth:

Considering the company's expected market share, the following tables shows the number of additional U.S. jobs created as a result of the projected industry growth to support new nuclear plants.

\begin{tabular}{|c|c|c|c|c|c|c|c|c|c|c|c|c|c|c|}
\hline Category & ‘09 & ' 10 & ' 11 & ' 12 & ' 13 & '14 & ' 15 & ' 16 & ' 17 & ' 18 & ' 19 & '20 & 221 & '22 \\
\hline Manufacturing Trades & * & & & & & & & & & & & & & \\
\hline Engineering & * & & & & & & & & & & & & & \\
\hline QA/QC & $*$ & & & & & & & & & & & & & \\
\hline Shipping and Receiving & $*$ & & & & & & & & & & & & & \\
\hline $\begin{array}{l}\text { Field Support (SU, service, } \\
\text { training, warranty, etc.) }\end{array}$ & $*$ & & & 10 & 10 & 10 & 10 & 20 & 20 & 20 & 20 & 40 & 20 & 20 \\
\hline Others, define & * & & & & 10 & 10 & 10 & 10 & 10 & 10 & 10 & 10 & 10 & 10 \\
\hline
\end{tabular}

\section{Quality Program:}

Company C does maintain a QA program in accordance with 10CFR50 Appendix B or NQA-1 to support the nuclear industry.

Threshold for Additional Expansion and Lead Time:

Company $\mathrm{C}$ stated they would not consider expansion unless they saw a clear competitive/cost advantage to manufacturing in the U.S. Additionally, they stated that the building of the nuclear plants would have to be long term U.S. commitment.

Incentives and Constraints:

Legislative or contractual requirements would cause Company $\mathrm{C}$ to repatriate jobs to the U.S.

Company $\mathrm{C}$ also stated that they have experienced problems in the sourcing of castings, forgings, piping and alloy steel. It is difficult to source these items in the U.S.

\section{Other Issues:}

Lower emissions and cost of electric power were noted as positive outcomes. 


\section{Commodity Summary and Indicators}

Three suppliers responded to the survey for this commodity. Company A sees no growth of U.S. jobs for the build-out of new NPPS since these jobs would most likely simply replace jobs that would otherwise be in support of the fossil business.

Company B is not a U.S. company. Company B would create a modest amount of jobs (19) to support their U.S. NPP business activities.

Company $\mathrm{C}$ is not a U.S. company. Company $\mathrm{C}$ also projected a modest job growth in their field support services organization.

\section{Special Issues}

None.

\section{Data Observations by Bechtel}

The responses by Companies A, B, and $\mathrm{C}$ did not yield consistent data that can be readily compared since Company A is a U.S. company, and Companies B and C are companies based outside the U.S. 


\section{Survey Results-Company A}

Current Employment:

Current employment level of the company's manufacturing business. Also, the number of jobs located domestically and outside the U.S. and the percentage of employees who have current or past nuclear experience. Company A has machinists, welders, assemblers, and testers within the manufacturing trades category.

\begin{tabular}{|l|c|c|c|}
\hline \multicolumn{1}{|c|}{ Category } & $\begin{array}{c}\text { Current } \\
\text { Employee } \\
\text { Level in U.S. }\end{array}$ & $\begin{array}{c}\text { Number } \\
\text { Outside the } \\
\text { U.S. }\end{array}$ & $\begin{array}{c}\text { \% With } \\
\text { Nuclear } \\
\text { Experience }\end{array}$ \\
\hline Manufacturing Trades & 632 & 520 & $40 \%$ \\
\hline Engineering & 58 & 54 & $50 \%$ \\
\hline QA/QC & 80 & 67 & $75 \%$ \\
\hline Shipping and Receiving & 8 & 2 & $50 \%$ \\
\hline $\begin{array}{l}\text { Field Support (startup, service, training, } \\
\text { warranty, etc.) }\end{array}$ & 8 & 8 & $75 \%$ \\
\hline Others, Sales, Admin, Finance, IT & 454 & 380 & $30 \%$ \\
\hline
\end{tabular}

Output, Capacity, and Market Share:

Manufacturing output (e.g., number of units produced annually) at the current employment level and shop load percentage at this production rate. This company's domestic market share and current overseas market share. This company's yearly sales volume and the percentage of this sales volume related to domestic/U.S. production.

500,000 units in various product lines. Although shop load varies, it is currently estimated at $80 \%$. Company A states market share is difficult to determine and although they are a large supplier, their share is less than 5\% worldwide. \$140 Million North American market with \$200 Million worldwide. U.S. production is \$30 Million. 
Projected Job Growth:

Considering the company's expected market share, the following tables shows the number of additional U.S. jobs created as a result of the projected industry growth to support new nuclear plants.

\begin{tabular}{|c|c|c|c|c|c|c|c|c|c|c|c|c|c|c|}
\hline Category & ‘09 & ' 10 & 11 & ' 12 & '13 & '14 & ' 15 & ' 16 & '17 & ' 18 & '19 & 20 & '21 & 22 \\
\hline Manufacturing Trades & $50 *$ & & & & & & & & & & & & & \\
\hline Engineering & 5 & & & & & & & & & & & & & \\
\hline $\mathrm{QA} / \mathrm{QC}$ & 2 & & & & & & & & & & & & & \\
\hline Shipping and Receiving & 1 & & & & & & & & & & & & & \\
\hline $\begin{array}{l}\text { Field Support (SU, service, } \\
\text { training, warranty, etc.) }\end{array}$ & 1 & & & & & & & & & & & & & \\
\hline Others, define & 4 & & & & & & & & & & & & & \\
\hline
\end{tabular}

* Company A stated these numbers would be applicable to each nuclear plant order they receive and the numbers should be multiplied accordingly.

Quality Program:

Company A currently maintains a QA program in accordance with 10CFR50 Appendix B or NQA-1 to support the nuclear industry in both U.S. and Canada. Two plants in Canada have a Nstamp and the U.S. has NQA-1 but could be easily upgraded. Company A at one time had three Canadian plants and one U.S. plant with N-stamps.

Threshold for Additional Expansion and Lead Time:

Company A stated that assuming current base load of work, the first order for a new nuclear plant would cause U.S. jobs be created.

Incentives and Constraints:

Company A stated that a firm demand for nuclear power plants would be required to build new manufacturing capacity/jobs in the U.S. and that a 1-year lead-time is needed to make this decision.

Other Issues:

Company A saw benefits of a stable workforce of qualified employees as jobs for other standard industries are disappearing. They have discussed the issue of job creation in the U.S. within the confines of their trade association (Valve Manufacturers Association of America). 


\section{Survey Results-Company B}

Current Employment:

Current employment level of the company's manufacturing business. Also, the number of jobs located domestically and outside the U.S. and the percentage of employees who have current or past nuclear experience.

\begin{tabular}{|l|c|c|c|}
\hline \multicolumn{1}{|c|}{ Category } & $\begin{array}{c}\text { Current } \\
\text { Employee } \\
\text { Level in U.S. }\end{array}$ & $\begin{array}{c}\text { Number } \\
\text { Outside the } \\
\text { U.S. }\end{array}$ & $\begin{array}{c}\text { \% With } \\
\text { Nuclear } \\
\text { Experience }\end{array}$ \\
\hline Manufacturing Trades * & 31 & 0 & $100 \%$ \\
\hline Engineering & 13 & 0 & $100 \%$ \\
\hline QA/QC & 13 & 0 & $100 \%$ \\
\hline Shipping and Receiving & 3 & 0 & $100 \%$ \\
\hline $\begin{array}{l}\text { Field Support (startup, service, training, } \\
\text { warranty, etc.) }\end{array}$ & 3 & 0 & $100 \%$ \\
\hline Others, define & 16 & 0 & $100 \%$ \\
\hline
\end{tabular}

Output, Capacity, and Market Share:

Manufacturing output (e.g., number of units produced annually) at the current employment level and shop load percentage at this production rate. This company's domestic market share and current overseas market share. This company's yearly sales volume and the percentage of this sales volume related to domestic/U.S. production.

10,000 units per year (mainly valves and spare parts)

no information on capacity provided

$70 \%$ domestic market share (for specialty valves)

$40 \%$ overseas market share

\$22M worldwide sales volume

$\$ 18.7 \mathrm{M}$ domestic sales 
Projected Job Growth:

Considering the company's expected market share, the following tables shows the number of additional U.S. jobs created as a result of the projected industry growth to support new nuclear plants.

\begin{tabular}{|c|c|c|c|c|c|c|c|c|c|c|c|c|c|c|}
\hline Category & '09 & '10 & ' 11 & ' 12 & ' 13 & $\cdot 14$ & '15 & '16 & '17 & '18 & ‘19 & 20 & 21 & '22 \\
\hline Manufacturing Trades & 0 & 0 & 2 & 0 & 4 & 0 & 0 & 0 & 0 & 0 & 0 & 0 & 0 & 0 \\
\hline Engineering & 2 & 0 & 1 & 0 & 1 & 0 & 0 & 0 & 0 & 0 & 0 & 0 & 0 & 0 \\
\hline QA/QC & 0 & 0 & 1 & 0 & 1 & 0 & 0 & 0 & 0 & 0 & 0 & 0 & 0 & 0 \\
\hline Shipping and Receiving & 0 & 0 & 0 & 0 & 0 & 0 & 0 & 0 & 0 & 0 & 0 & 0 & 0 & 0 \\
\hline $\begin{array}{l}\text { Field Support (SU, service, } \\
\text { training, warranty, etc.) }\end{array}$ & 0 & 0 & 0 & 0 & 0 & 0 & 0 & 0 & 0 & 0 & 0 & 0 & 0 & 0 \\
\hline Others, define & 0 & 0 & 0 & 0 & 0 & 0 & 0 & 0 & 0 & 0 & 0 & 0 & 0 & 0 \\
\hline
\end{tabular}

Quality Program:

Company B does currently maintain a QA program in accordance with 10CFR50 Appendix B or NQA-1 to support the nuclear industry.

Threshold for Additional Expansion and Lead Time:

Company B stated the second order for a new nuclear plant would cause U.S. jobs to be created. All new jobs (and current jobs are) would be in the U.S. Six months would be required for expanding production capability.

Incentives and Constraints:

Company B stated no incentives are required. Company B also has concerns in foundry capability and quality of bellows in the U.S.

Other Issues:

Company B saw benefits from elimination of hydrocarbon emissions and the manufacturing of $\mathrm{H}_{2}$ as a fuel. They have not discussed the issue of job creation in the U.S. within the confines of any of their respective trade associations. 


\section{Survey Results-Company C}

Current Employment:

Current employment level of the company's manufacturing business. Also, the number of jobs located domestically and outside the U.S. and the percentage of employees who have current or past nuclear experience.

\begin{tabular}{|l|c|c|c|}
\hline \multicolumn{1}{|c|}{ Category } & $\begin{array}{c}\text { Current } \\
\text { Employee } \\
\text { Level in U.S. }\end{array}$ & $\begin{array}{c}\text { Number } \\
\text { Outside the } \\
\text { U.S. }\end{array}$ & $\begin{array}{c}\text { \% With } \\
\text { Nuclear } \\
\text { Experience }\end{array}$ \\
\hline Manufacturing Trades & 68 & 0 & $20 \%$ \\
\hline Engineering & 8 & 0 & $100 \%$ \\
\hline QA/QC & 6 & 0 & $80 \%$ \\
\hline Shipping and Receiving & & & $100 \%$ \\
\hline $\begin{array}{l}\text { Field Support (startup, service, training, } \\
\text { warranty, etc.) }\end{array}$ & 8 & 0 & \\
\hline Others, define & & & \\
\hline
\end{tabular}

Output, Capacity, and Market Share:

Manufacturing output (e.g., number of units produced annually) at the current employment level and shop load percentage at this production rate. This company's domestic market share and current overseas market share. This company's yearly sales volume and the percentage of this sales volume related to domestic/U.S. production.

\$40M year. \$38M U.S. total.

$60 \%$ capacity

$25 \%$ in served share

$2 \%$ overall valve market 
Projected Job Growth:

Considering the company's expected market share, the following tables shows the number of additional U.S. jobs created as a result of the projected industry growth to support new nuclear plants.

\begin{tabular}{|c|c|c|c|c|c|c|c|c|c|c|c|c|c|c|}
\hline Category & '09 & ' 10 & '11 & '12 & '13 & ' 14 & ' 15 & ' 16 & $' 17$ & ' 18 & ' 19 & '20 & '21 & 22 \\
\hline Manufacturing Trades & Manufacturing Trades & 144 & 288 & 144 & 0 & 144 & 144 & 144 & 144 & 0 & 0 & 0 & 0 & 0 \\
\hline Engineering & Engineering & 5 & 9 & 5 & 0 & 5 & 4 & 5 & 4 & 0 & 0 & 0 & 0 & 0 \\
\hline $\mathrm{QA} / \mathrm{QC}$ & $\mathrm{QA} / \mathrm{QC}$ & 10 & 19 & 9 & 0 & 10 & 10 & 9 & 10 & 0 & 0 & 0 & 0 & 0 \\
\hline Shipping and & Shipping and & 0 & 0 & 0 & 0 & & & & & & & & & \\
\hline Receiving & Receiving & & & & & & & & & & & & & \\
\hline $\begin{array}{l}\text { Field Support (SU, } \\
\text { service, training, } \\
\text { warranty, etc.) }\end{array}$ & $\begin{array}{l}\text { Field Support (SU, } \\
\text { service, training, } \\
\text { warranty, etc.) }\end{array}$ & 0 & 0 & 0 & 0 & & & & & & & & & \\
\hline Others, define & Others, define & 0 & 0 & 0 & 0 & & & & & & & & & \\
\hline
\end{tabular}

Quality Program:

Company C currently maintains a QA program in accordance with 10CFR50 Appendix B or NQA-1 to support the nuclear industry and also has N and NPT authorization from ASME.

Threshold for Additional Expansion and Lead Time:

Company $\mathrm{C}$ stated that addition of one new plant would initiate the job growth. Equipment may be a constraint for them.

Incentives and Constraints:

Company $\mathrm{C}$ stated that incentives of $4+$ unit commitments over 6 to 8 years would initiate job growth and production expansion.

Other Issues:

Company $\mathrm{C}$ sees benefits from a clean fuel and reducing foreign dependency as a nuclear advantage. They identified U.S. qualified foundry capability as a problem along with qualified material suppliers and personnel versed in nuclear codes. They have discussed the issue of job creation in the U.S. within the confines of their trade association (Valve Manufacturers Association of America). 


\section{Survey Results-Company D}

Current Employment:

Current employment level of the company's manufacturing business. Also, the number of jobs located domestically and outside the U.S. and the percentage of employees who have current or past nuclear experience.

\begin{tabular}{|l|c|c|c|}
\hline \multicolumn{1}{|c|}{ Category } & $\begin{array}{c}\text { Current } \\
\text { Employee } \\
\text { Level in U.S. }\end{array}$ & $\begin{array}{c}\text { Number } \\
\text { Outside the } \\
\text { U.S. }\end{array}$ & $\begin{array}{c}\text { \% With } \\
\text { Nuclear } \\
\text { Experience }\end{array}$ \\
\hline Manufacturing Trades * & 191 & 0 & $100 \%$ \\
\hline Engineering & 44 & 0 & $100 \%$ \\
\hline QA/QC & 26 & 0 & $100 \%$ \\
\hline Shipping and Receiving & 5 & 0 & $100 \%$ \\
\hline $\begin{array}{l}\text { Field Support (startup, service, training, } \\
\text { warranty, etc.) }\end{array}$ & 11 & 0 & $100 \%$ \\
\hline Others, define & 34 & 0 & $100 \%$ \\
\hline
\end{tabular}

Output, Capacity, and Market Share:

Manufacturing output (e.g., number of units produced annually) at the current employment level and shop load percentage at this production rate. This company's domestic market share and current overseas market share. This company's yearly sales volume and the percentage of this sales volume related to domestic/U.S. production.

25,000 units per year

$70 \%$ capacity

$25 \%$ domestic market share

$10 \%$ overseas market share

$\$ 80 \mathrm{M}$ worldwide sales volume

$\$ 76 \mathrm{M}$ domestic sales 
Projected Job Growth:

Considering the company's expected market share, the following tables shows the number of additional U.S. jobs created as a result of the projected industry growth to support new nuclear plants.

\begin{tabular}{|c|c|c|c|c|c|c|c|c|c|c|c|c|c|c|}
\hline Category & 609 & ' 10 & '11 & '12 & '13 & $‘^{\prime} 14$ & '15 & 16 & '17 & '18 & 19 & 20 & 21 & '22 \\
\hline Manufacturing Trades & 33 & 99 & 200 & 266 & 333 & 400 & 416 & 433 & 433 & 450 & 450 & 300 & 150 & 0 \\
\hline Engineering & 8 & 12 & 16 & 18 & 24 & 30 & 30 & 30 & 30 & 30 & 24 & 12 & 6 & 3 \\
\hline $\mathrm{QA} / \mathrm{QC}$ & 3 & 10 & 20 & 27 & 33 & 40 & 42 & 43 & 43 & 45 & 45 & 30 & 15 & 5 \\
\hline \multicolumn{15}{|l|}{ Shipping and Receiving - in mfr. } \\
\hline $\begin{array}{l}\text { Field Support (SU, service, training, } \\
\text { warranty, etc.) }\end{array}$ & 0 & 0 & 1 & 2 & 3 & 4 & 4 & 4 & 4 & 4 & 4 & 4 & 4 & 4 \\
\hline Others, define & 8 & 8 & 12 & 16 & 18 & 24 & 30 & 30 & 30 & 30 & 24 & 12 & 6 & 3 \\
\hline
\end{tabular}

Quality Program:

Company D does currently maintain a QA program in accordance with 10CFR50 Appendix B or NQA-1 to support the nuclear industry.

Threshold for Additional Expansion and Lead Time:

Company D stated the first order for a new nuclear plant would cause U.S. jobs to be created. They are currently adding jobs to support overseas plants.

Incentives and Constraints:

Company D stated no incentives are required. Company D also has concerns about the availability of nuclear castings suppliers in the U.S. They would need 6 months to 1 year to expand capacity of their plants.

Other Issues:

Company D saw benefits from a cleaner, more stable source of energy and lower dependence on foreign oil. They have discussed the issue of job creation in the U.S. within the confines of their trade association (Valve Manufacturers Association of America). 


\section{Commodity Summary and Indicators}

Four suppliers were surveyed for this commodity. Company A, who claims an less than 5\% market share, projects adding 63 manufacturing jobs per plant order to support the nuclear power build-out.

Company B claims $70 \%$ of the domestic market (for specialty valves) and projects to add 12 manufacturing jobs between 2009 and 2013 to support the deployment of new nuclear facilities in the U.S.

Company $\mathrm{C}$, who claims a $25 \%$ market share in their served market and $2 \%$ overall, projects adding a large amount of employees (see table) in manufacturing jobs to support the nuclear power build-out through 2020.

Company D, who claims a $25 \%$ market share in their served market and $10 \%$ overall, projects adding a large amount of employees (see table) in manufacturing jobs to support the nuclear power build-out through 2022. Company D also saw engineering job growth (8) in 2008 and added jobs in 2023 and 2024.

There are indications that there would be growth in manufacturing jobs, for this sector as well as a sustaining of jobs that will have been added to support the current active international market for valves.

\section{Special Issues}

Companies in this survey have expressed concern over the casting and foundry capability.

\section{Data Observations by Bechtel}

The companies in this survey have provided a diverse estimate of the number of additional employees and since Company B supplies specialty valves, their market shares are overstated (more than 100\% has been accounted for here). This wide disparity in responses and the market shares indicate the basis for the estimates are not common and any data manipulation should take this into account. Since Company B supplies specialty valves, their estimates should not be taken as representative of the whole industry. 


\section{Current Employment:}

Company A has total of 3000 employees, all in the U.S. A breakdown of employee category is not available from this company.

\begin{tabular}{|l|l|l|l|}
\hline \multicolumn{1}{|c|}{ Category } & $\begin{array}{c}\text { Current } \\
\text { Employee } \\
\text { Level in U.S. }\end{array}$ & $\begin{array}{c}\text { Number } \\
\text { Outside the } \\
\text { U.S. }\end{array}$ & $\begin{array}{c}\text { \% With } \\
\text { Nuclear } \\
\text { Experience }\end{array}$ \\
\hline Manufacturing Trades & & & \\
\hline Engineering & & & \\
\hline QA/QC & & & \\
\hline Shipping and Receiving & & & \\
\hline $\begin{array}{l}\text { Field Support (startup, service, training, } \\
\text { warranty, etc.) }\end{array}$ & & & \\
\hline Others, define & & & \\
\hline
\end{tabular}

Output, Capacity, and Market Share:

Manufacturing output (e.g., number of units produced annually) at the current employment level and shop load percentage at this production rate. This company's domestic market share and current overseas market share. This company's yearly sales volume and the percentage of this sales volume related to domestic/U.S. production.

$\$ 650 \mathrm{M}$ per year of revenue

$80-85 \%$ shop load

$40 \%$ U.S. market share 
Projected Job Growth:

Company A stated that for the build-out rate expected, they do not need to add any new jobs. Their existing employment level is sufficient to absorb the new equipment orders.

\begin{tabular}{|c|c|c|c|c|c|c|c|c|c|c|c|c|c|c|}
\hline Category & ' 09 & ' 10 & '11 & ' 12 & ‘13 & '14 & ' 15 & ' 16 & ‘ 17 & ‘ 18 & ‘19 & '20 & '21 & '22 \\
\hline Manufacturing Trades & & & & & & & & & & & & & & \\
\hline Engineering & & & & & & & & & & & & & & \\
\hline $\mathrm{QA} / \mathrm{QC}$ & & & & & & & & & & & & & & \\
\hline Shipping and Receiving & & & & & & & & & & & & & & \\
\hline $\begin{array}{l}\text { Field Support (SU, service, } \\
\text { training, warranty, etc.) }\end{array}$ & & & & & & & & & & & & & & \\
\hline Others, define & & & & & & & & & & & & & & \\
\hline
\end{tabular}

Quality Program:

Company A does not maintain a QA program in accordance with 10CFR50 Appendix B or NQA-1 to support the nuclear industry. Due to decline of nuclear industry, they have not renewed their Nuclear QA program.

Threshold for Additional Expansion and Lead Time:

Company A stated that addition of one new plant will initiate the job growth. Company A stated that they require 1 to 2 years of lead-time for the company to make a decision to build new production capacity.

Incentives and Constraints:

Company A stated that only a letter of intent for the purchase of their product approximately 9 months before the order will be necessary. They see a shortage of raw materials, e.g., carbon and stainless steel as constraints for their market.

Other Issues:

None. 


\section{Commodity Summary and Indicators}

Two suppliers were approached for this commodity. Only one company provided the input. Company A, claims 30\% market share, and is projecting job growth of 170 jobs starting in 2009 through 2012.

There are strong indications that there would be some moderate growth in manufacturing jobs.

\section{Special Issues}

Company A has a concern for shortage in carbon steel supply and energy costs for the manufacturing sector. 


\section{Fabricated Parts \& Components}

\section{Survey Results_Company A}

Current Employment:

Current employment level of the company's manufacturing business. Also, the number of jobs located domestically and outside the U.S. and the percentage of employees who have current or past nuclear experience.

\begin{tabular}{|l|c|c|c|}
\hline \multicolumn{1}{|c|}{ Category } & $\begin{array}{c}\text { Current } \\
\text { Employee } \\
\text { Level in U.S. }\end{array}$ & $\begin{array}{c}\text { Number } \\
\text { Outside the } \\
\text { U.S. }\end{array}$ & $\begin{array}{c}\text { \% With } \\
\text { Nuclear } \\
\text { Experience }\end{array}$ \\
\hline Manufacturing Trades & 60 & 0 & 33 \\
\hline Engineering & 5 & 0 & 80 \\
\hline QA/QC & 4 & 0 & 75 \\
\hline Shipping and Receiving & 2 & 0 & 0 \\
\hline $\begin{array}{l}\text { Field Support (startup, service, training, } \\
\text { warranty, etc.) }\end{array}$ & 0 & 0 & 0 \\
\hline Others, define & 6 & 0 & 33 \\
\hline
\end{tabular}

Output, Capacity, and Market Share:

Manufacturing output (e.g., number of units produced annually) at the current employment level and shop load percentage at this production rate. This company's domestic market share and current overseas market share. This company's yearly sales volume and the percentage of this sales volume related to domestic/U.S. production.

In U.S. \$23.5M/year. \$1.5M/year outside the U.S.

$70 \%$ capacity (1 full shift plus parts of other shifts)

-domestic market share

-overseas market share 
Projected Job Growth:

Considering the company's expected market share, the following tables shows the number of additional U.S. jobs created as a result of the projected industry growth to support new nuclear plants.

\begin{tabular}{|c|c|c|c|c|c|c|c|c|c|c|c|c|c|c|}
\hline Category & ‘ 09 & '10 & '11 & ' 12 & ‘ 13 & '14 & ‘ 15 & '16 & ' 17 & '18 & '19 & 20 & 21 & 22 \\
\hline Manufacturing Trades & 20 & 20 & 10 & 0 & 20 & 20 & 20 & 10 & 0 & 20 & 0 & 0 & 0 & 0 \\
\hline Engineering & 2 & 1 & 1 & 0 & 1 & 2 & 1 & 1 & 0 & 1 & 0 & 0 & 0 & 0 \\
\hline QA/QC & 2 & 1 & 1 & 0 & 1 & 2 & 1 & 1 & 0 & 1 & 0 & 0 & 0 & 0 \\
\hline Shipping and Receiving & 1 & 1 & 0 & 0 & 1 & 1 & 1 & 0 & 0 & 1 & 0 & 0 & 0 & 0 \\
\hline $\begin{array}{l}\text { Field Support (SU, service, } \\
\text { training, warranty, etc.) }\end{array}$ & 0 & 0 & 0 & 0 & 0 & 0 & 0 & 0 & 0 & 0 & 0 & 0 & 0 & 0 \\
\hline Others, define & 2 & 1 & 1 & 0 & 1 & 2 & 1 & 1 & 0 & 1 & 0 & 0 & 0 & 0 \\
\hline
\end{tabular}

\section{Quality Program:}

Company A currently maintains a QA program in accordance with 10CFR50 Appendix B or NQA-1 to support the nuclear industry.

Threshold for Additional Expansion and Lead Time:

Company A stated that positions would be added upon receipt of the first order and building new facilities or expanding existing facilities would be required upon subsequent orders. If expansion was under taken, Company A indicated that the 9-month lead-time would be required make a decision to build new production capacity.

Incentives and Constraints:

Company A stated that commitments to "Buy American" would be needed to entice expansion and/or addition of new facilities. Company A expressed concerns with labor supply, domestic steel plate supply and machining sources as constraints for meeting the demand for new nuclear generation plants.

Other Issues:

Company A saw added security for the U.S. industrial base as a benefit to the potential build-out of new nuclear generation. They have also not discussed the issue of job creation in the U.S. within the confines of their trade association (Steel Plate Fabrication Association - SPFA). 


\section{Commodity Summary and Indicators}

Only one supplier was surveyed for these services. Company A represents the subsupplier sector of the market place. Company A typically fabricates specialty items for manufactures and suppliers for their end product.

This Company has been included as an indicator representing potential job growth for subsuppliers as a result of new nuclear generation plants. Although vendor and manufacturers have estimate potential job growth the new nuclear generation plants would have on their organization, none have estimated the potential impacts on subsuppliers like Company A.

\section{Special Issues}

None identified.

\section{Data Observations by Bechtel}

Company A provides specialized fabrication capabilities to vendor and manufactures in the nuclear market. Company A has been provided in this survey as an indicator that vendor and manufacturer job growth projections only account for a fraction of the total potential job growth that would be realized through the overall build-out. 
Annex A-Summary of Number of Surveyed Companies by Commodity

\section{New Nuclear Power Generation}

\section{Supply Chain Survey}

\begin{tabular}{|l|c|c|}
\hline \multicolumn{1}{|c|}{ Equipment Type } & $\begin{array}{c}\text { Number } \\
\text { of } \\
\text { Suppliers } \\
\text { Targeted }\end{array}$ & $\begin{array}{c}\text { Number of } \\
\text { Completed } \\
\text { Surveys }\end{array}$ \\
\hline Cable & 1 & 0 \\
\hline Cement & 1 & 1 \\
\hline Compressors/Vacuum Pumps & 2 & 0 \\
\hline Condensers (Main) & 2 & 1 \\
\hline Control Valves & 2 & 2 \\
\hline Cooling Towers & 1 & 0 \\
\hline Cranes & 2 & 2 \\
\hline Dampers/Louvers & 3 & 0 \\
\hline Diesel Generators & 2 & 2 \\
\hline Fans & 2 & 1 \\
\hline Heat Exchangers & 4 & 2 \\
\hline Load Centers 480 V, MCC \& Switchgear & 3 & 2 \\
\hline Pipe $>2$ " & 2 & 2 \\
\hline Prefabricated Equipment Modules & 2 & 1 \\
\hline Pumps, Large and Small & 4 & 4 \\
\hline Reactor Vessels and Large Components & 4 & 4 \\
\hline Reinforcing Steel & 2 & 2 \\
\hline Structural Steel & 3 & 2 \\
\hline Tanks (Shop Fabricated) & 1 & 1 \\
\hline Tanks (Field Erected) & 3 & 2 \\
\hline Turbine/Generator Sets & 5 & 3 \\
\hline Valves & 2 & 4 \\
\hline Water Treatment Plants & 1 & 1 \\
\hline Fabricated Parts and Components & 2 & \\
\hline & 2 & 2 \\
\hline
\end{tabular}


Annex B - Blank Survey Package with Cover Letter 
To: $\quad$ Survey Participants

From: David Hammerle

Bechtel Power Corporation

Date:

Subject: Department of Energy Supply Chain Survey

New Nuclear Power Generation

Impact on U.S. Manufacturing Sector Jobs

The Department of Energy (DOE) has requested input from the U.S. manufacturing sector to gauge the impact of new nuclear electric generation deployment in the U.S. over the next two decades. As a first step DOE has asked Bechtel to perform a survey of the industry to quantify the impact on U.S. jobs based upon a set of simplifying assumptions about the potential build-out rate.

The results of the survey will be used by DOE and their stakeholders to further formulate the federal government's programs and plans to resurrect the nuclear industry. As a major supplier to the electric power industry your input is being requested to support the survey.

The DOE plans to issue a report with the summarized results of survey. Because of the nature of the survey questions, the identity of the responders to the survey will not be disclosed in the final report.

The DOE has asked that this survey be conducted with a very aggressive schedule. Because of the schedule we plan to contact you by telephone between Monday, Sep 20, and Wednesday, Sep 22 , to conduct the survey via telephone. You are asked to confirm your survey responses, in writing, to the address (or e-mail address) listed below.

Vivian McDonnell

Purchasing Manager

Bechtel Power Corp.

5275 Westview Drive

Frederick, MD 21703

vlmcdonn@bechtel.com

The survey contains background information and instructions that will hopefully be selfexplanatory. If you have questions, comments, or would like to discuss the survey before you begin please call Ms. McDonnell at 301-228-8552 so we can help you get started.

DOE and Bechtel would like to thank you in advance for your support and participation in this important study.

\section{New Nuclear Power Generation}




\section{Supply Chain Survey}

\section{$\underline{\text { Introduction and Purpose }}$}

We have been requested by the Department of Energy (DOE) to perform a survey of major equipment and commodity suppliers to the electric power industry. The purpose of this survey is to determine the impact on the number of manufacturing jobs in the U.S., resulting from the construction of the new generation of advanced reactors in the U.S.

Blue-collar manufacturing jobs in the U.S. have undergone significant reductions for several recent years because labor costs in other countries are putting pressure on U.S. competitiveness. More recently, white-collar technology jobs have followed suit, because offshore-educated labor wages remain lower than wages in the U.S.

At the same time, the U.S. is facing higher energy prices as countries like India and China begin to demand more of the world's oil production to feed their growing economies. The availability and security of oil imports is fast becoming a national concern leading to the need of energy independence for the U.S. This is leading many to consider nuclear power as a viable option. The rate at which the new generation of nuclear plants will be constructed in the U.S. is uncertain. According to the Energy Information Administration (EIA), the statistical arm of the DOE, the nation will need 355,000 megawatts of new and replacement electrical generation within the next two decades, assuming electricity demand grows at the modest rate of 1.8 percent per year. Because reliable and affordable electricity is the backbone of the nation's economic and national security, the nuclear energy industry in 2001 set forth a long-term vision of the industry's future. The cornerstone of that vision is adding 50,000 megawatts of new nuclear electric generating capacity to the national grid by 2020 . This national vision is referred to as "Vision 2020"3.

There are several major reactor vendors that are actively pursuing U.S.NRC design certification approvals for their advanced reactors. The electrical output of these plants ranges from about 1200 to $1500 \mathrm{MWe}$. This means to reach the 50,000 megawatt goal of Vision 2020, between 33 to 41 plants would need to be constructed. Based on these assumptions and assuming the first plant is ordered in about 2009, this would require that plants be constructed at the rate shown below in Figure 1. The earliest plant could be operating by about 2014. This build-out of nuclear plants in the U.S. will occur approximately in parallel with a significant planned build-out in China, Korea and elsewhere overseas.

\footnotetext{
${ }^{3}$ Nuclear Energy and the Nation's Future Prosperity, Nuclear Energy Institute, www.nei.org
} 


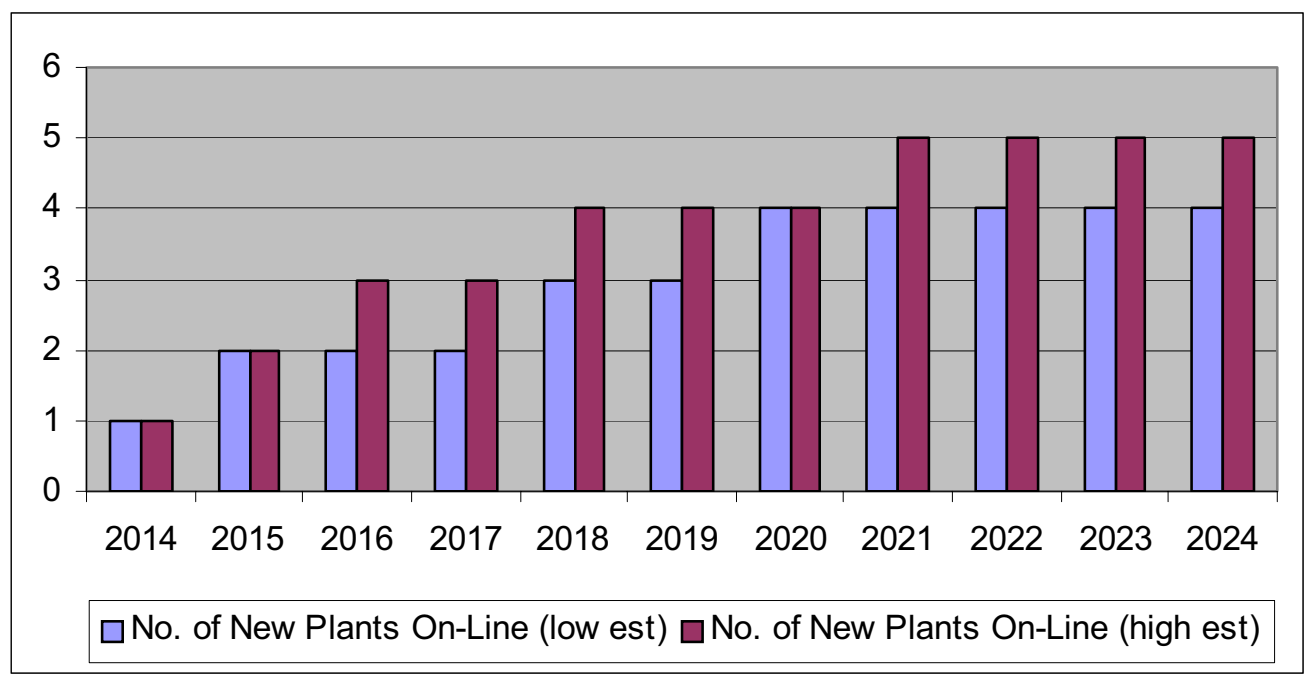

Figure 1-Estimate of New Nuclear Plants Operating, by Year

Depending upon the type of reactor chosen, the type and quantity of equipment and bulk commodities to construct the plant will vary. Attached to this survey are several tables (Tables 1(a), 1(b), 1(c), 1(d), and 1(e)) which summarize the approximate ranges of equipment and commodities that would be needed to construct a single hypothetical nuclear plant. Your survey challenge is to project (over time) the U.S. jobs created to support the manufacture of equipment and/or commodities produced by your company. We would like your estimate to be based upon the build-out rate of plants shown in Figure 1 above and the quantities required for each plant provided in the attached tables.

For a new nuclear plant to be placed in operation, the planning and procurement process begins several year in advance of the startup date. We would like you to consider this lead-time in your responses to our survey. To assist you in understanding lead times see Figure 2 that illustrates, for a typical single unit plant, a simplified schedule for permitting, design, construction and startup of an advanced reactor. This figure was taken from a report prepared for the DOE under Cooperative Agreement DE-FC07-03ID14492 ${ }^{4}$.

${ }^{4}$ Study of Construction Technologies and Schedules, O\&M Staffing and Cost, Decommissioning Costs and Funding Requirements for Advanced Reactor Designs", May 27, 2004. 


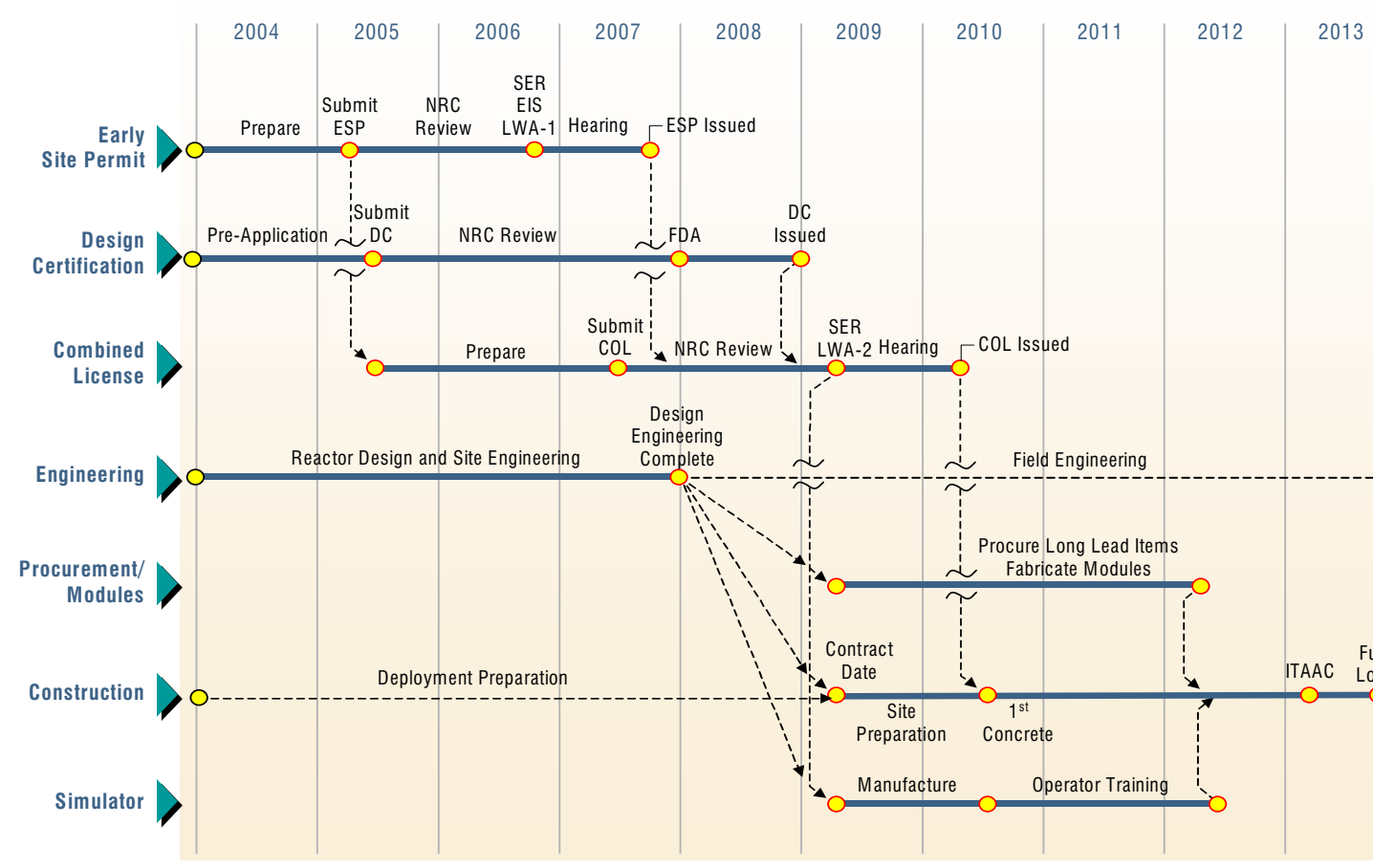


As seen from this schedule, the procurement of long-lead equipment will begin about 5 years prior to plant startup.

Our schedule to obtain survey results for the DOE is very aggressive. Therefore we have limited both the number of survey questions, as well as the number of survey participants (to major suppliers who are either currently actively supporting the nuclear industry or suppliers who may have an interest over the long term in supporting new nuclear power plants, as described above). The survey results will provide the DOE with a basic understanding of the relationship between the number of new nuclear power plants to be built in the U.S. and the number and types of U.S. manufacturing jobs created as a result. Thus, one key result of the survey from your company is a table that projects job growth as a function of job type over time.

It should be noted that nuclear quality assurance would be a necessary element of the manufacturer's scope of work. Although the "new generation" of nuclear power plants designs have fewer components that are nuclear safety related compared to the current fleet, a portion of the equipment will require quality assurance programs in accordance with 10CFR50 Appendix B or NQA-1. Also, because of the NRC's new permitting process for the new generation plants, the $\mathrm{NRC}$ and/or the licensee may need to perform certain inspections in the manufacturer's shops. These inspections plans will be developed under the new ITAAC (Inspections, Tests, Analyses, and Acceptance Criteria) rules that are currently under review between industry groups and the NRC.

The attached equipment lists do not distinguish between items that will require nuclear versus non-nuclear QA because this information is not readily available. In general for the new generation of plants, the percentage of components that will require nuclear QA will be significantly lower than the current fleet of operating plants.

\section{Survey Instructions}

All participants will be contacted via phone by a Bechtel representative who will obtain verbal responses to the survey questions. Please review the survey questions in advance to facilitate this discussion. Participants will also be asked to submit their input in writing within 3 days of the phone survey. Particular attention should be given to Question \# 7 where we are asking that you provide a tabularized estimate of additional manufacturing jobs to support new nuclear plants, categorized by job type, over the period of manufacturing depicted by Figure 1. 


\section{SURVEY QUESTIONS}

1. Provide the current employment level of your company's manufacturing business. See the table below question \# 3 .

2. Are any of these jobs located outside the U.S.? If so, how many? See the table below question \# 3 .

3. What percentage of the employees have current or past nuclear experience?

\begin{tabular}{|l|c|c|c|}
\hline \multicolumn{1}{|c|}{ Category } & $\begin{array}{c}\text { Current } \\
\text { Employee } \\
\text { Level }\end{array}$ & $\begin{array}{c}\text { Number } \\
\text { Outside the } \\
\text { U.S. }\end{array}$ & $\begin{array}{c}\text { \% with nuclear } \\
\text { experience }\end{array}$ \\
\hline Manufacturing Trades * & & & \\
\hline Engineering & & & \\
\hline QA/QC & & & \\
\hline Shipping and Receiving & & & \\
\hline $\begin{array}{l}\text { Field Support (startup, service, training, } \\
\text { warranty, etc.) }\end{array}$ & & & \\
\hline Others, define & & & \\
\hline
\end{tabular}

*Identify the trade categories

4. At this employment level what is your manufacturing output (e.g., number of units produced annually). What is the shop load percentage at this production rate?

5. What is your current domestic market share? What is your current overseas market share?

6. What is the yearly sales volume for your company? What percentage of this sales volume is related to domestic/U.S. production?

7. Based on the attached equipment quantity forecast and your company's expected market share, what would be the number of additional U.S. jobs created as a result of the projected industry growth to support new nuclear plants? If possible provide your response in a table or spreadsheet that gives a breakdown of additional U.S. jobs in the categories below over the time frame of Figure 1.

\begin{tabular}{|l|l|l|l|l|l|l|}
\hline \multicolumn{1}{|c|}{ Category } & $\mathbf{2 0 0 9}$ & $\mathbf{2 0 1 0}$ & $\mathbf{2 0 1 1}$ & $\mathbf{2 0 1 2}$ & $\mathbf{2 0 1 3}$ & Etc. \\
\hline Manufacturing Trades & & & & & & \\
\hline Engineering & & & & & & \\
\hline QA/QC & & & & & & \\
\hline Shipping and Receiving & & & & & & \\
\hline $\begin{array}{l}\text { Field Support (SU, service, training, warranty, } \\
\text { etc.) }\end{array}$ & & & & & & \\
\hline Others, define & & & & & & \\
\hline
\end{tabular}

8. Does your company currently maintain a QA program in accordance with 10CFR50 Appendix B or NQA-1 to support the nuclear industry?

9. If not now, has your company ever maintained such a QA program? If yes, why was the program discontinued? 
10. Question \# 7 asked what additional U.S. jobs would be created under a scenario with a 'full' build-out of new nuclear electric generation. At what threshold of demand for your products would U.S. jobs be created to support new nuclear plants?

11. What incentives, if any, would be required to build new manufacturing capacity in the U.S.?

12. What incentives, if any, would be required to repatriate jobs to the U.S.?

13. Please identify any constraints, concerns, or other issues that may arise as a result of the additional demands on your subsuppliers for materials, products and services.

14. How much lead-time is required by your company to make a decision to build new production capacity?

15. What benefits, other than U.S. job growth, do you envision by the potential build-out of new nuclear generation?

16. Has the issue of job creation in the U.S. been discussed within the confines of any trade associations of which you are a member? Can you refer us to the trade association?

\section{ATTACHMENTS}

Table 1(a)—Hypothetical New Nuclear Unit Composite Equipment List Summary (1 page)

Table 1(b) - Hypothetical New Nuclear Unit Bulk Quantity List (1 page)

Table 1(c) - Hypothetical New Nuclear Unit Instrument List (1 page)

Table 1(d) - Hypothetical New Nuclear Unit Valve List Summary (1 page)

Table 1 (e) - Hypothetical New Nuclear Unit Valve List Details (8 pages) 
Hypothetical New Nuclear Unit*

Composite Equipment List Summary

\begin{tabular}{|c|c|c|}
\hline Equipment Type & Number (Range) & Comments \\
\hline Pumps, Large & $71-100$ & $\begin{array}{l}\text { All sizes, types, materials. Pumps }>10 \mathrm{hp} \text { and/or }> \\
12,000 \mathrm{lbs} \text { dry weight }\end{array}$ \\
\hline Pumps, Small & $80-484$ & $\begin{array}{l}\text { All sizes, types, materials. Pumps }<12,000 \text { lbs dry } \\
\text { weight and/or }<10 \mathrm{hp}\end{array}$ \\
\hline Tanks & $49-150$ & $\begin{array}{l}\text { All sizes, materials. Includes building sumps. Dry } \\
\text { weights from } 600 \text { to } 150,000 \mathrm{lbs}\end{array}$ \\
\hline Steam Generators & $0-4$ & \\
\hline Reactor Vessels & $1-2$ & \\
\hline Compressors/Vacuum Pumps & $12-26$ & All sizes, types. \\
\hline Damper/Louvers & $730-1170$ & All sizes, types. \\
\hline Cranes and Hoists & $25-50$ & All sizes, types. \\
\hline Diesel Generators & 2 & Approx $10 \mathrm{MWe}$ \\
\hline Control Room Displays & 1 set & \\
\hline Reactor Protection and Control System & 1 set & \\
\hline Plant Simulator & 1 set & \\
\hline MCC Sets & $19-37$ & \\
\hline 480 V Load Centers & $7-13$ & \\
\hline Switchgear & 1 set & \\
\hline
\end{tabular}

*-Not reflective of any specific reactor design. Unit size is approximately 1200-1500 MWe. 
Table 1(b)

Hypothetical New Nuclear Unit Bulk Quantity List

\begin{tabular}{|l|r|}
\hline \multicolumn{1}{|c|}{ Commodity } & \multicolumn{1}{|c|}{ Total } \\
\hline Concrete, CY & 425,555 \\
\hline Structural Steel, Tons** & 18,857 \\
\hline Pipe $>2$ ", feet** & 369,513 \\
\hline Tray/conduit, feet & 206,494 \\
\hline Cable, feet & $6,979,621$ \\
\hline
\end{tabular}

**-excludes quantities on prefabricated modules

Estimates are not reflective of any specific reactor. Unit size is approx 1200-1500 MWe. 
Table 1(c) - Hypothetical New Nuclear Unit Instrument List

\begin{tabular}{lrr}
\multicolumn{1}{c}{ Instrument Summary } & $\begin{array}{c}\text { Qty } \\
\text { Low }\end{array}$ & $\begin{array}{c}\text { Qty } \\
\text { High }\end{array}$ \\
\hline Voltage Element & 270 & 501 \\
Vibration Transmitter & 28 & 52 \\
Temperature Transmitter & 4 & 8 \\
Temperature Element & 431 & 800 \\
Speed/Frequency Transmitter & 3 & 5 \\
Radioactivity Transmitter & 1 & 3 \\
Radioactivity Element & 28 & 52 \\
Pressure Transmitter & 228 & 423 \\
Pressure Element & 13 & 23 \\
Position Sensing Element & 43 & 79 \\
Neutron Flux Element & 171 & 317 \\
Moisture Transmitter & 11 & 20 \\
Moisture Element & 8 & 16 \\
Level Transmitter & 123 & 228 \\
Flow Transmitter & 145 & 269 \\
Flow Elements & 126 & 234 \\
Differential Pressure Transmitter & 111 & 205 \\
Conductivity Transmitter & 9 & 17 \\
Conductivity Element & 22 & 42 \\
Analysis Transmitter & 13 & 25 \\
Analysis Element & 67 & 124 \\
Total & $\mathbf{1 8 5 2}$ & $\mathbf{3 4 4 0}$
\end{tabular}

Note - Quantities are reflective of any specific reactor type. 
Table 1(d) - Hypothetical New Nuclear Unit Valve List Summary

\begin{tabular}{|c|c|c|c|c|c|}
\hline \multicolumn{2}{|c|}{ Valve Summary } & \multirow{2}{*}{$\begin{array}{l}\text { Qty Range } \\
\text { Low }\end{array}$} & \multirow{2}{*}{$\begin{array}{c}\text { Qty Range } \\
\text { High }\end{array}$} & \multirow[b]{2}{*}{ Type } & \multirow[b]{2}{*}{ Operator } \\
\hline English & Metric & & & & \\
\hline $1 / 2 "$ & 15 & 158 & 294 & Various & Various \\
\hline 1" & 25 & 3952 & 7340 & Various & Various \\
\hline $11 / 2 "$ & 40 & 382 & 710 & Various & Various \\
\hline 2" & 50 & 1918 & 3562 & Various & Various \\
\hline 3" & 80 & 531 & 985 & Various & Various \\
\hline 4" & 100 & 609 & 1131 & Various & Various \\
\hline 6" & 150 & 699 & 1297 & Various & Various \\
\hline $8 "$ & 200 & 251 & 465 & Various & Various \\
\hline 10" & 250 & 245 & 455 & Various & Various \\
\hline $12 "$ & 300 & 347 & 645 & Various & Various \\
\hline 16" & 400 & 238 & 442 & Various & Various \\
\hline $20 "$ & 500 & 119 & 221 & Various & Various \\
\hline 24" & 600 & 31 & 57 & Various & Various \\
\hline $28 "$ & 700 & 49 & 91 & Butterfly & Electrohydraulic \\
\hline $30 "$ & 750 & 25 & 47 & & Air \\
\hline $36 "$ & 900 & 22 & 42 & Various & Various \\
\hline 42" & & 22 & 42 & & \\
\hline $54 "$ & & 20 & 36 & & \\
\hline 90" & & 11 & 21 & & \\
\hline $108 "$ & & 4 & 8 & & \\
\hline & & 9633 & 17891 & & \\
\hline
\end{tabular}

Notes: 1. Quantities are not reflective of any specific reactor type

1. For details of valve quantities shown above see Table 1(e) 


\section{Table 1(e) - Hypothetical New Nuclear Unit Valve List Details (page 1 of 8) For Valve Summary see Table 1(d)}

\begin{tabular}{llrr}
\multicolumn{1}{c}{ 36" Valve Summary } & \multicolumn{1}{c}{ Operator } & Low & High \\
\hline Butterfly & Motor & 11 & 21 \\
Butterfly & Air & 11 & 21 \\
Gate & Motor & 0 & 0 \\
Check & Air & 0 & 0
\end{tabular}

\begin{tabular}{llrr}
\multicolumn{1}{c}{ 24" Valve Summary } & Operator & Low & \multicolumn{1}{r}{ High } \\
\hline Butterfly & Hand & 14 & 26 \\
Butterfly & Air w/positioner & 8 & 16 \\
Ball & Air w/positioner & 3 & 5 \\
Gate & Hand & 0 & 0 \\
Gate & Motor & 6 & 10 \\
Check & Air & 0 & 0 \\
Turb Stop/Cont & Electro-hydraulic & 0 & 0
\end{tabular}

\begin{tabular}{llrr}
\multicolumn{1}{c}{ 20" Valve Summary } & Operator & Low & \multicolumn{1}{c}{ High } \\
\hline Butterfly & Motor & 0 & 0 \\
Butterfly & Hand & 8 & 16 \\
Butterfly & Air w/positioner & 29 & 55 \\
Check & Self & 0 & 0 \\
Gate & Motor & 45 & 83 \\
Gate & Air & 3 & 5 \\
Gate & Hand & 34 & 62 \\
Safety Relief & Self & 0 & 0
\end{tabular}

\begin{tabular}{llrr}
\multicolumn{1}{c}{ 16" Valve Summary } & \multicolumn{1}{c}{ Operator } & \multicolumn{2}{c}{ High } \\
\hline Butterfly & Hand & 17 & 31 \\
Butterfly & Motor & 34 & 62 \\
Butterfly & Air & 8 & 16 \\
Butterfly & Air w/positioner & 0 & 0 \\
Check & Self & 0 & 0 \\
Check & Air & 6 & 10 \\
Globe & Air w/positioner & 113 & 211 \\
Gate & Motor & 34 & 62 \\
Gate & Hand & 27 & 49 \\
Gate & Pneumatic-hydraulic & 0 & 0
\end{tabular}


Table 1(e) - Hypothetical New Nuclear Unit Valve List Details (page 2 of 8) For Valve Summary see Table 1(d)

\begin{tabular}{|c|c|c|c|}
\hline 12" Valve Summary & Operator & Low & High \\
\hline Butterfly & Hand & 77 & 143 \\
\hline Butterfly & Motor & 11 & 21 \\
\hline Butterfly & Air & 15 & 29 \\
\hline Ball & Motor & 10 & 18 \\
\hline Ball & Air w/positioner & 4 & \\
\hline Check & Self & 0 & \\
\hline Globe & Air w/positioner & 3 & \\
\hline Globe & Motor & 7 & 13 \\
\hline Gate & Post Ind & 0 & \\
\hline Gate & Hand & 158 & 294 \\
\hline Gate & Motor & 62 & 114 \\
\hline 10" Valve Summary & Operator & Low & High \\
\hline Butterfly & Hand & 76 & 140 \\
\hline Butterfly & Air & 24 & 44 \\
\hline Squib & Explosive & 0 & \\
\hline Safety/relief & Self & 0 & 0 \\
\hline Ball & Air w/positioner & 0 & \\
\hline Check & Self & 0 & \\
\hline Check & Air & 0 & \\
\hline Globe & Air w/positioner & 0 & 0 \\
\hline Gate & Motor & 11 & 21 \\
\hline Gate & Hand & 134 & 250 \\
\hline Gate & Post Ind & 0 & 0 \\
\hline
\end{tabular}

\begin{tabular}{llrr}
\multicolumn{1}{c}{ 8" Valve Summary } & \multicolumn{1}{r}{ Operator } & \multicolumn{1}{r}{ High } \\
\hline Butterfly & Hand & 78 & 146 \\
Butterfly & Motor & 3 & 5 \\
Butterfly & Air & 4 & 8 \\
Butterfly & Air w/positioner & 4 & 8 \\
Check & Self & 0 & 0 \\
Deluge & Self & 0 & 0 \\
Globe & Air w/positioner & 11 & 21 \\
Globe & Air & 0 & 0 \\
Globe & Motor & 0 & 0 \\
Globe & Hand & 3 & 5 \\
Ball & Air w/positioner & 3 & 5 \\
Gate & Motor & 3 & 5 \\
Gate & Hand & 126 & 234 \\
Alarm Check & Self & 0 & 0 \\
Auto Recirc & Self & 0 & 0 \\
Safety/Relief & Self & 15 & 29
\end{tabular}


Table 1(e) - Hypothetical New Nuclear Unit Valve List Details (page 3 of 8) For Valve Summary see Table 1(d)

\begin{tabular}{llrr}
\multicolumn{1}{c}{ 6" Valve Summary } & \multicolumn{1}{c}{ Operator } & Low & High \\
\hline Butterfly & Hand & 122 & 226 \\
Butterfly & Motor & 0 & 0 \\
Butterfly & Air & 13 & 23 \\
Butterfly & Electro-hydraulic & 0 & 0 \\
Check & Self & 0 & 0 \\
Deluge & Self & 0 & 0 \\
Globe & Air w/positioner & 6 & 10 \\
Globe & Air & 0 & 0 \\
Globe & Hand & 0 & 0 \\
Ball & Air w/positioner & 13 & 23 \\
Ball & Hand & 0 & 0 \\
Gate & Motor & 24 & 44 \\
Gate & Hand & 469 & 871 \\
Gate & Air & 10 & 18 \\
Gate & Post Ind & 0 & 0 \\
3-Way & Motor & 0 & 0 \\
3-Way & Air w/positioner & 0 & 0 \\
Dry Pipe & Self & 0 & 0 \\
Safety/Relief & Self & 43 & 81 \\
Squib & Explosive & 0 & 0 \\
Stop Check & Hand & 0 & 0 \\
& & &
\end{tabular}


Table 1(e) - Hypothetical New Nuclear Unit Valve List Details (page 4 of 8) For Valve Summary see Table 1(d)

\begin{tabular}{llrr}
\multicolumn{1}{c}{ 4" Valve Summary } & \multicolumn{1}{r}{ Operator } & High \\
\hline Butterfly & Hand & 28 & 52 \\
Butterfly & Motor & 0 & 0 \\
Butterfly & Air & 0 & 0 \\
Butterfly & Electro-hydraulic & 0 & 0 \\
Butterfly & Air w/positioner & 0 & 0 \\
Check & Self & 0 & 0 \\
Deluge & Self & 0 & 0 \\
Globe & Air w/positioner & 0 & 0 \\
Globe & Air & 6 & 10 \\
Globe & Hand & 18 & 34 \\
Globe & Motor & 17 & 31 \\
Globe & Process Fluid & 0 & 0 \\
Globe & Special & 3 & 5 \\
Ball & Air w/positioner & 13 & 23 \\
Ball & Hand & 99 & 185 \\
Gate & Motor & 39 & 73 \\
Gate & Air & 6 & 10 \\
Gate & Hand & 381 & 707 \\
3-Way Plug & Air w/positioner & 0 & 0 \\
3-Way & Hand & 0 & 0 \\
3-Way & Air w/positioner & 0 & 0 \\
Alarm Check & Self & 0 & 0 \\
Auto Recric & Self & 0 & 0 \\
Safety/Relief & Self & 0 & 0 \\
Plug & Hand & 0 & 0
\end{tabular}


Table 1(e) - Hypothetical New Nuclear Unit Valve List Details (page 5 of 8) For Valve Summary see Table 1(d)

\begin{tabular}{llrr}
\multicolumn{1}{c}{ 3" Valve Summary } & \multicolumn{1}{r}{ Operator } & \multicolumn{2}{r}{ High } \\
\hline Butterfly & Hand & 24 & 44 \\
Butterfly & Air & 6 & 10 \\
Butterfly & Air w/positioner & 0 & 0 \\
Check & Self & 0 & 0 \\
Dry Pipe & Self & 0 & 0 \\
Globe & Air w/positioner & 6 & 10 \\
Globe & Air & 25 & 47 \\
Globe & Hand & 15 & 29 \\
Globe & Motor & 0 & 0 \\
Ball & Air & 11 & 21 \\
Ball & Hand & 136 & 252 \\
Ball & Motor & 3 & 5 \\
Gate & Motor & 13 & 23 \\
Gate & Air & 4 & 8 \\
Gate & Hand & 265 & 491 \\
Gate & Process Fluid & 3 & 5 \\
3-Way & Electro-hydraulic & 6 & 10 \\
3-Way & Air & 0 & 0 \\
3-Way Plug & Air & 0 & 0 \\
Vacuum Breaker & Self & 0 & 0 \\
Stop Check & Self & 0 & 0 \\
Safety/Relief & Self & 15 & 29 \\
Plug & Hand & 0 & 0 \\
Plug & Air & 0 & 0
\end{tabular}


Table 1(e) - Hypothetical New Nuclear Unit Valve List Details (page 6 of 8) For Valve Summary see Table 1(d)

\begin{tabular}{llrr}
\multicolumn{1}{c}{ 2" Valve Summary } & Operator & \multicolumn{2}{r}{ High } \\
\hline Angle Globe & Air w/positioner & 0 & 0 \\
Angle Globe & Hand & 0 & 0 \\
Butterfly & Air & 0 & 0 \\
Check & Self & 0 & 0 \\
Dry Pipe & Self & 0 & 0 \\
Globe & Air w/positioner & 1 & 3 \\
Globe & Air & 25 & 47 \\
Globe & Hand & 0 & 0 \\
Globe & Process Fluid & 28 & 52 \\
Globe & Solenoid & 4 & 8 \\
Globe & Motor & 15 & 29 \\
Globe & Special & 3 & 5 \\
Ball & Air & 15 & 29 \\
Ball & Motor & 1 & 3 \\
Ball & Hand & 232 & 432 \\
Gate & Air & 7 & 13 \\
Gate & Hand & 1562 & 2902 \\
Gate & Motor & 15 & 29 \\
Gate & Process Fluid & 0 & 0 \\
3-Way & Hand & 0 & 0 \\
3-Way Plug & Air & 0 & 0 \\
Hermetically Sealed Globe & Self & 0 & 0 \\
Pinch & Self & 0 & 0 \\
Safety/Relief & Self & 7 & 13 \\
Plug & Hand & 0 & 0 \\
Plug & Air & 0 & 0
\end{tabular}


Table 1(e) - Hypothetical New Nuclear Unit Valve List Details (page 7 of 8) For Valve Summary see Table 1(d)

\begin{tabular}{|c|c|c|c|}
\hline 1 1/2" Valve Summary & Operator & Low & High \\
\hline Ball & Hand & 179 & 333 \\
\hline Ball & Air & 3 & 5 \\
\hline Ball & Motor & 3 & 5 \\
\hline Check & Self & 0 & 0 \\
\hline Gate & Hand & 178 & 330 \\
\hline Globe & Air w/positioner & 6 & 10 \\
\hline Globe & Air & 1 & 3 \\
\hline Safety/Relief & Self & 13 & 23 \\
\hline 1" Valve Summary & Operator & Low & High \\
\hline Angle Globe & Hand & 0 & 0 \\
\hline Check & Self & 0 & 0 \\
\hline Globe & Air w/positioner & 0 & 0 \\
\hline Globe & Air & 17 & 31 \\
\hline Globe & Hand & 74 & 138 \\
\hline Globe & Process Fluid & 0 & 0 \\
\hline Globe & Motor & 17 & 31 \\
\hline Globe & Solenoid & 84 & 156 \\
\hline Ball & Air & 20 & 36 \\
\hline Ball & Air w/positioner & 0 & 0 \\
\hline Ball & Solenoid & 0 & 0 \\
\hline Ball & Hand & 1551 & 2881 \\
\hline Gate & Air & 4 & 8 \\
\hline Gate & Solenoid & 0 & 0 \\
\hline Gate & Hand & 2037 & 3783 \\
\hline Gate & Motor & 17 & 31 \\
\hline Gate & Process Fluid & 3 & 5 \\
\hline 3-Way & Hand & 0 & 0 \\
\hline 3-Way & Solenoid & 18 & 34 \\
\hline 3-Way & Air & 0 & 0 \\
\hline Hermetically Sealed Globe & Hand & 0 & 0 \\
\hline Needle & Hand & 0 & 0 \\
\hline Safety/Relief & Self & 111 & 205 \\
\hline Plug & Hand & 0 & 0 \\
\hline Vacuum Breaker & Self & 0 & 0 \\
\hline
\end{tabular}


Table 1(e) - Hypothetical New Nuclear Unit Valve List Details (page 8 of 8) For Valve Summary see Table 1(d)

\begin{tabular}{|c|c|c|c|}
\hline 3/4" Valve Summary & Operator & Low & High \\
\hline Ball & Hand & 0 & 0 \\
\hline Globe & Hand & 0 & 0 \\
\hline 1/2" Valve Summary & Operator & Low & High \\
\hline Check & Self & 0 & 0 \\
\hline Globe & Hand & 0 & 0 \\
\hline Globe & Solenoid & 143 & 265 \\
\hline Ball & Drip & 0 & \\
\hline Ball & Hand & 0 & 0 \\
\hline Hermetically Sealed Globe & Hand & 0 & \\
\hline Needle & Hand & 0 & 0 \\
\hline Safety/Relief & Self & 15 & 29 \\
\hline
\end{tabular}


Appendix B 


\section{Appendix B: Nuclear Plant Employment Impact Regression Analyses}

The economic impact studies from the Nuclear Engineering Institute (NEI) provide economic impact data that is based on using sophisticated input-output macroeconomic models to determine employment impacts of nuclear plant operations on the national economy [NEI, February 2004; NEI, April 2004; NEI, July 2003; NEI, March 2004]. The Dominion constructability study provides additional data on plant employment that enhances and validates the NEI data. The Bechtel Power supplier survey provides economic impact data that is reflects microeconomic impacts on individual firms that can be used to determine employment impacts of commodity requirements for new plant construction on national employment. We used the results from these studies and performed regression analyses to determine the deterministic equations for expected jobs and probability distributions needed to simulate uncertainties.

The methodology used by NEI to estimate the economic and fiscal impacts of power plants is commonly referred to as input/output methodology. Several operational input/output models are available in the marketplace - the market leaders are Impact Analysis for Planning (IMPLAN), REMI and RIMS-II. The IMPLAN model was selected by NEI for use in their studies, primarily because the model and many of the data sets were already on hand, the relevance of IMPLAN to the particular application, and its transparency and ease of use.

The IMPLAN data and account structure closely follow the accounting conventions used in input/output studies of the U.S. economy by the Department of Commerce's Bureau of Economic Analysis. The comprehensive and detailed data coverage of the entire United States, by county, and the ability to incorporate user-supplied data at each stage of the model-building process provide a high degree of flexibility both in terms of geographic coverage and model formulation. The impact of an economic activity in any sector or geographic area on other sectors and areas can be modeled. These impacts can extend well beyond the sector and area in which the original economic activity is located.

Job creation impacts modeled by IMPLAN are divided into their direct and secondary effects. The direct effects reflect the industry sector employment without any subsequent spending effects. The direct employment values used in NEI studies are the actual plant employment values from operating plants. The secondary, or "ripple," effects include subsequent employment effects, which can be further divided into indirect and induced. Indirect effects reflect how a power plant's spending patterns alter subsequent employment among suppliers. For the NEI studies, the indirect employment effects were modeled based on actual expenditures for outside goods and services at the plants. Induced effects reflect how changes in labor income for direct and indirect employment influence the final demand for goods and services, which then has an employment impact on all sectors producing basic, intermediate and final goods and services. For the NEI studies, the induced employment effects were modeled using established input/output modeling parameters to estimate local, regional, and national employment impacts of labor income.

In addition to the NEI studies, a constructability study for advanced reactor designs provides estimates of direct jobs for operation of $3^{\text {rd }}$ Generation plants [Dominion Energy, et al, May 27, 2004]. The most detailed information was available on the ABWR. With two plants operating, and four others under construction, the final design details are available for the design. In addition, staffing and plant maintenance requirements for this design were determined from actual operating experience. The ABWR is the only design that has an equivalent of a U.S.-type human factors review of the control room design. Two separate staffing models were developed. The first was for a green field site deployment of approximately 1100 to $1400 \mathrm{MWe}$. For the designs evaluated in this study, this was assumed to be a 
single new unit or a twin unit for the ACR-700. Another staffing model was developed for the deployment additional units of the same 1100 to 1400 MWe range of new reactor types on an existing operational nuclear site. This staffing model assumes that site staff and services will be shared. The data from this second model for additional units are not used in this study because it is unclear how many new plants will be operating as an additional unit, and the staffing model itself does not have adequate data from operational facilities to validate the amount of reduction in staff required for an additional unit that the model predicts.

\section{B.1. NUCLEAR POWER PLANT PRODUCTION FUNCTION REGRESSION ANALYSIS}

The first relationship to be fit is the equation that relates plant capacity and plant direct employment. Using classical economic production models, we let

$$
E_{\text {direct }}=\alpha C^{\beta}
$$

where $E_{\text {direct }}$ is the direct employment at the plant, $C$ is the plant capacity in megawatts (MWe), $\alpha$ and $\beta$ are coefficients to be fit. Taking logarithms of 0 , we have

$$
\ln \left(E_{\text {direct }}\right)=\ln (\alpha)+\beta \ln (C)
$$

which was used as the linear model for a linear regression fit with all of the direct employment and capacity data from the NEI studies [NEI, February 2004; NEI, April 2004; NEI, July 2003; NEI, March 2004] and the Dominion constructability report [Dominion Energy, et al, May 27, 2004]. The regression fit is done using data from Table B-1 below. As an example of filling in Table B-1, we go to Table 3.5 in the Indian Point report and use the United States Direct Employment value of 1,683 for $E_{\text {direct }}$, and go to Table 2.1 from the Indian Point report to get the capacity of the two operating units of $984 \mathrm{MW}$ and 994 MW to derive a total of 1,978 for the value of $C$.

Table B-1. Direct Employment and Capacity Raw Data

\begin{tabular}{|l|l|l|c|c|c|c|}
\hline $\mathbf{i}$ & Plant Name & Data Source & $\mathbf{E}_{\text {direct }}$ & $\mathbf{C}_{\mathbf{i}}$ & $\ln \left(\mathbf{E}_{\text {direct }}\right)$ & $\ln (\mathbf{C})$ \\
\hline 1 & Indian Point & NEI, April 2004 & 1,683 & 1,978 & 7.43 & 7.59 \\
\hline 2 & Diablo Canyon & NEI, February 2004 & 1707 & 2200 & 7.44 & 7.70 \\
\hline 3 & Millstone & NEI, July 2003 & 1464 & 2020 & 7.29 & 7.61 \\
\hline 4 & North Anna & Dominion et al & 1106 & 1842 & 7.01 & 7.52 \\
\hline 5 & Oyster Creek & NEI, March 2004 & 451 & 637 & 6.11 & 6.46 \\
\hline 6 & ABWR Greenfield & Dominion et al & 701 & 1371 & 6.55 & 7.22 \\
\hline 7 & ESBWR Greenfield & Dominion et al & 700 & 1340 & 6.55 & 7.20 \\
\hline 8 & ACR-700 Greenfield & Dominion et al & 761 & 1406 & 6.63 & 7.25 \\
\hline 9 & AP1000 Greenfield & Dominion et al & 698 & 1150 & 6.55 & 7.05 \\
\hline
\end{tabular}


Table 3-5 from Indian Point Report. Impact of Indian Point Energy Center on Local State and National Economies

\begin{tabular}{|l|l|l|l|l|}
\hline \hline & Direct & Indirect & Induced & Total \\
\hline Local Area & & & & \\
Output & $\$ 650,000,000$ & $\$ 26,523,396$ & $\$ 86,764,515$ & $\$ 763,287,899$ \\
Labor Income & $\$ 126,583,000$ & $\$ 10,913,021$ & $\$ 33,942,648$ & $\$ 171,438,669$ \\
Employment & 1,355 & 280 & 918 & 2,553 \\
\hline New York State & & & & \\
Output Labor Income & $\$ 650,000,000$ & $\$ 54,621,790$ & $\$ 107,125,921$ & $\$ 811,747,691$ \\
Employment & $\$ 145,933,008$ & $\$ 22,632,196$ & $\$ 42,535,089$ & $\$ 211,100,309$ \\
\hline United States & 1,559 & 488 & 1,132 & 3,179 \\
\hline Output Labor Income & $\$ 650,000,000$ & $\$ 382,945,230$ & $\$ 491,311,999$ & $\$ 1,524,257,225$ \\
Employment & $\$ 161,202,704$ & $\$ 175,593,811$ & $\$ 173,867,555$ & $\$ 510,664,071$ \\
\hline
\end{tabular}

Table 2-1 from Indian Point Report. The Indian Point Energy Center at a Glance

\begin{tabular}{|l|l|l|l|l|}
\hline \hline Unit & Capacity (MW) & $\begin{array}{l}\text { Commercial } \\
\text { Operation Year }\end{array}$ & $\begin{array}{l}\text { Year of License } \\
\text { Expiration }\end{array}$ & Reactor Type \\
\hline Unit 1 & 275 & 1962 & In Decommissioning & PWR \\
Unit 2 & 984 & 1974 & 2013 & PWR \\
Unit 3 & 994 & 1976 & 2015 & PWR \\
\hline
\end{tabular}

Once Table B-1 was filled in, a regression fit of 0 was performed to get a fit to the values for $\ln (\alpha)$ and $\beta$, which we will call $L A^{*}$ and $B^{*}$. The values for these two parameters for the data in Table B-1 are:

$$
\begin{gathered}
L A^{*}=-1.423725804 \\
B^{*}=1.133974722
\end{gathered}
$$

Figure B-1 below shows the raw data and the curve fit for the production function of 0 . 


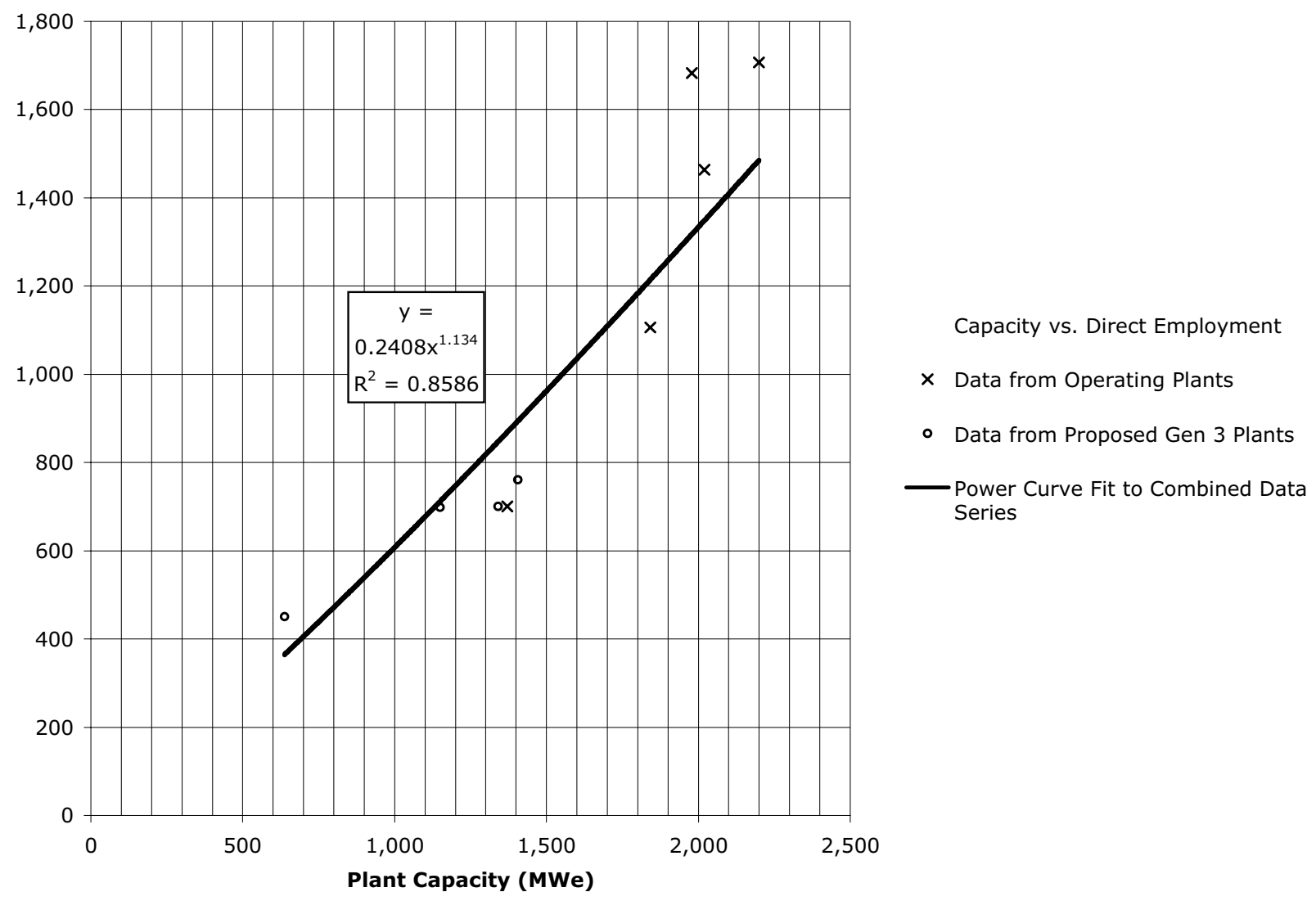

Figure B-1. Production Function Relating Direct Employment to Capacity for Nuclear Power Plants

If we want to predict direct employment for a given input value of $C$, we use the equation that relates the predicted value of $\ln \left(E_{\text {direct }}\right)$, which we will call $L E^{*}$,

$$
L E^{*}=L A^{*}+B^{*} \times \ln (C)
$$

From two-variable linear model theory [Johnston, pp. 38-41], this estimate actually is the mean of the logarithm of the direct employment level. The statistic

$$
t_{n-2}=\frac{\ln \left(E_{\text {direct }}\right)-L E^{*}}{\sqrt[s]{\frac{1}{n}+\frac{\left(\ln (C)-\frac{1}{n} \sum_{i=1}^{n} \ln \left(C_{i}\right)\right)^{2}}{\sum_{i=1}^{n}\left[\ln \left(C_{i}\right)-\frac{1}{n} \sum_{i=1}^{n} \ln \left(C_{i}\right)\right]^{2}}}}
$$

is distributed as Student's $t$ with n-2 degrees of freedom where

$E_{\text {direct }}=$ the true value of the direct employment level,

$n=$ the number of data points used to perform the regression with the data in Table B-1, 
$C=$ the capacity value for which we are making the prediction,

$C_{i}=$ the capacity values of the data points used to perform the regression in Table B-1, and $s=\frac{1}{n-2} \sum_{i=1}^{n}\left[\ln \left(E_{\text {direct }}(i)\right)-L A^{*}-L B^{*} \ln \left(C_{i}\right)\right]^{2}$, the estimate of the standard error estimate for the observation error from the regression.

Solving 0 for $E_{\text {direct, }}$, and substituting using 0 , we have

$$
E_{\text {direct }}=\exp \left\{L A^{*}+B^{*} \times \ln (C)+t_{n-2} S \sqrt{\frac{1}{n}+\frac{\left(\ln (C)-\frac{1}{n} \sum_{i=1}^{n} \ln \left(C_{i}\right)\right)^{2}}{\sum_{i=1}^{n}\left[\ln \left(C_{i}\right)-\frac{1}{n} \sum_{i=1}^{n} \ln \left(C_{i}\right)\right]^{2}}}\right\} .
$$

Substituting calculated values from Table B-1 into 0 , gives the following relationship to generate a Monte Carlo sample for $E_{\text {direct }}$ for each new plant with capacity $C$ that comes on line:

$$
E_{\text {direct }}=\exp \left\{-1.423725804+1.133974722 \times \ln (C)+0.188718415 \times t_{7} \sqrt{\frac{1}{9}+\frac{(\ln (C)-7.29)^{2}}{1.177351299}}\right\}
$$

\section{B.2. DIRECT PLANT EMPLOYMENT, INDIRECT EMPLOYMENT, AND INDUCED EMPLOYMENT REGRESSION ANALYSIS}

A standard econometric model relating direct employment to indirect and induced is to use multiple linear regression. The relationship is assumed to be

$$
\begin{aligned}
& E_{\text {indirect }}=A_{\text {indirect }}+B_{\text {indirect }} E_{\text {direct }} \\
& E_{\text {induced }}=A_{\text {induced }}+B_{\text {induced }} E_{\text {direct }}
\end{aligned}
$$

where

$E_{\text {direct }}=$ the direct labor in full-time equivalent (FTE) positions required,

$E_{\text {indirect }}=$ the indirect labor in full-time equivalent (FTE) positions required to support a plant,

$E_{\text {induced }}=$ the induced labor in full-time equivalent (FTE) positions that result from direct and indirect labor income,

$A_{\text {indirect }}=$ the regression function intercept parameter for indirect employment,

$B_{\text {indirect }}=$ the regression function slope parameter for indirect employment,

$A_{\text {induced }}=$ the regression function intercept parameter for induced employment, and 
$B_{\text {induced }}=$ the regression function slope parameter for induced employment.

Table B-2 below shows the data available from the NEI reports, and parameters for the multiple regression that best fits the data. The total of indirect and induced job estimate is calculated by combining the relationships of indirect and induced employment to direct employment as follows:

$$
\begin{aligned}
E_{\text {total }} & =E_{\text {indirect }}+E_{\text {induced }} \\
& =A_{\text {indirect }}+B_{\text {indirect }} E_{\text {direct }}+A_{\text {induced }}+B_{\text {induced }} E_{\text {direct }} \\
& =\left(A_{\text {indirect }}+A_{\text {induced }}\right)+\left(B_{\text {indirect }}+B_{\text {induced }}\right) E_{\text {direct }} \\
& =\left(A_{\text {indirect }}+A_{\text {induced }}\right)+\left(B_{\text {indirect }}+B_{\text {induced }}\right) E_{\text {direct }} \\
& =3699.8+2.15 \times E_{\text {direct }}
\end{aligned}
$$

Table B-2. Multiple Regression Results for Indirect and Induced Employment

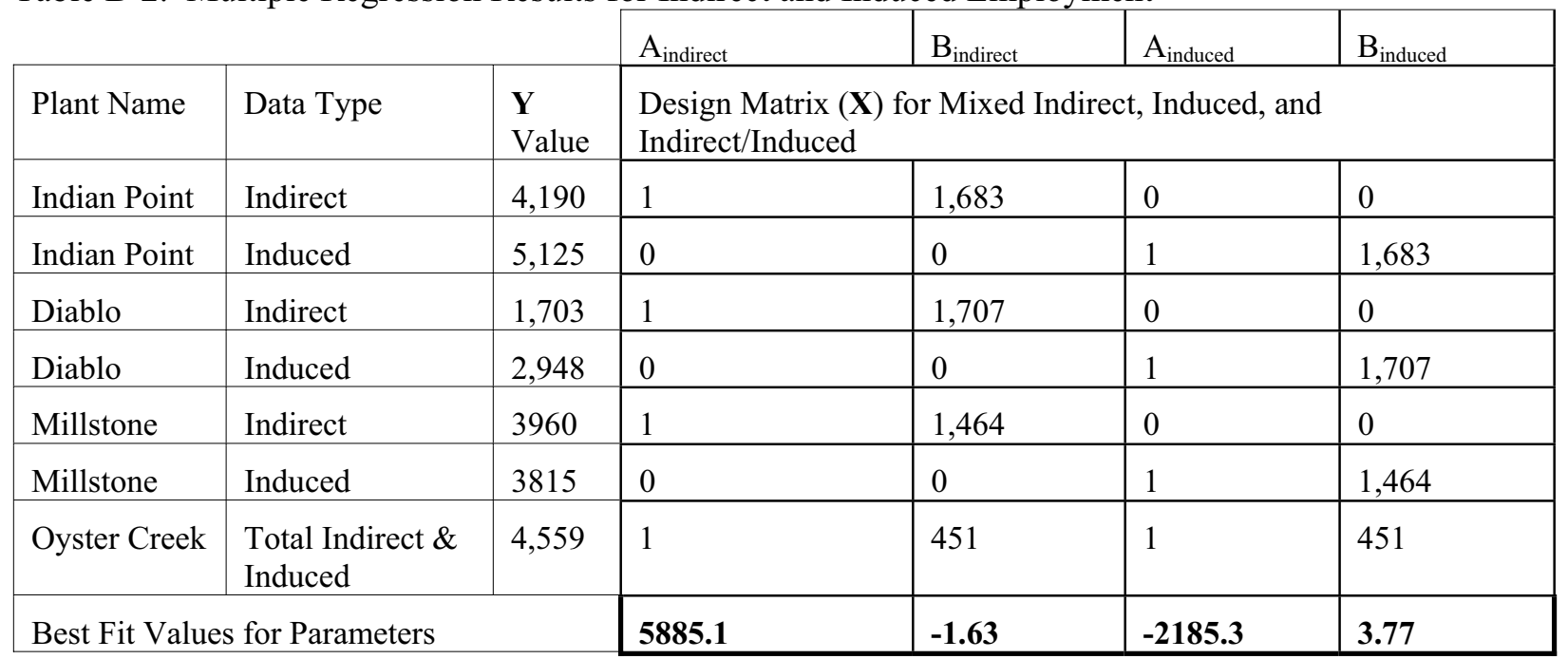

We use general linear model theory [Johnston, pp. 152-155] to develop statistical distributions for performing Monte Carlo analysis of the indirect and induced job estimates. Letting

$$
\hat{\boldsymbol{\beta}}=\left[\begin{array}{c}
\hat{A}_{\text {indirect }} \\
\hat{B}_{\text {indirect }} \\
\hat{A}_{\text {induced }} \\
\hat{B}_{\text {induced }}
\end{array}\right]
$$

be the vector of bit fits for the regression parameters shown in the last row of Table B-2. The statistic

$$
t_{n-4}=\frac{\mathbf{c}^{T} \hat{\boldsymbol{\beta}}-\mathbf{c}^{T} \boldsymbol{\beta}}{s \sqrt{\mathbf{c}^{T}\left(\mathbf{X}^{T} \mathbf{X}\right)^{-1} \mathbf{c}}}
$$

is distributed as Student's $\mathrm{t}$ with $\mathrm{n}-4$ degrees of freedom where 
$\beta=$ the true value of regression parameters,

$\hat{\boldsymbol{\beta}}=$ the best fit value of regression parameters,

$n=$ the number of data points used to perform the regression with the data in Table B-2,

$\mathrm{c}=$ an 4-dimensonal vector of constants that define the estimation that for which we are computing statistics,

$\mathrm{X}=$ the design matrix of the data points used to perform the regression in Table B-2, and

$s=$ the estimate of the standard error estimate for the observation error from the regression.

Solving 0 for $\mathbf{c}^{\mathrm{T}} \boldsymbol{\beta}$. we have

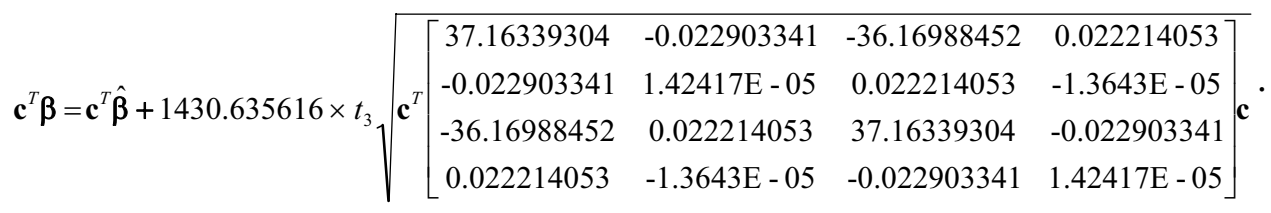

The Monte Carlo distribution for indirect jobs is implemented by substituting

$$
\mathbf{c}=\left[\begin{array}{c}
1 \\
E_{\text {direct }} \\
0 \\
0
\end{array}\right]
$$

into 0 to yield

$$
\begin{aligned}
& E_{\text {indirect }}=5885.079747-1.62988664 E_{\text {direct }}
\end{aligned}
$$

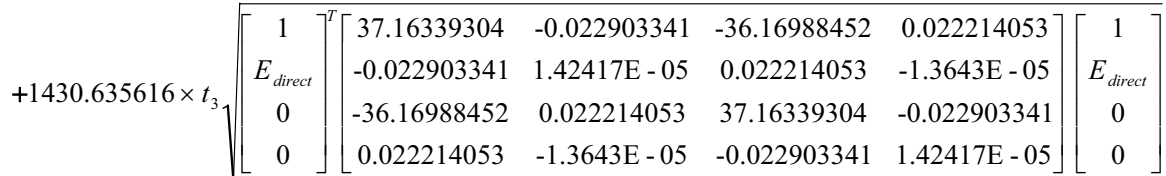

$$
\begin{aligned}
& =5885.079747-1.62988664 E_{\text {direct }} \\
& +1430.635616 \times t_{3}\left[37.16339304-2 \times 0.022903341 E_{\text {direct }}+\left(1.42417 \mathrm{E}-05 E_{\text {direct }}\right)^{2}\right]
\end{aligned}
$$

Similarly for induced jobs, 0 is implemented substituting

$$
\mathbf{c}=\left[\begin{array}{c}
1 \\
E_{\text {direct }} \\
0 \\
0
\end{array}\right]
$$

For total induced and indirect jobs, 0 is implemented using 


$$
\mathbf{c}=\left[\begin{array}{c}
1 \\
E_{\text {direct }} \\
1 \\
E_{\text {direct }}
\end{array}\right] \text {. }
$$

\section{B.3. MODELING THE RELATIONSHIP BETWEEN CONSTRUCTION EMPLOYMENT AND INDUCED EMPLOYMENT}

In addition to indirect and induced employment resulting from direct plant employment, there also is indirect and induced employment from direct construction jobs during the period when a plant is being built.

The indirect jobs created from construction jobs are manufacturing jobs that provide the commodities from which the plant is constructed. The model for determining indirect jobs due to plant construction is driven by a supplier survey and is described in B.4 below.

For induced employment, we use the parameters defined in B.3 to calculate the induced jobs due to construction employment.

$$
E C_{\text {induced }}=A_{\text {induced }}+B_{\text {induced }} E_{\text {construction }}
$$

where

$E_{\text {construction }}=$ the direct labor in full-time equivalent (FTE) positions required for construction,

$E C_{\text {induced }}=$ the induced labor in full-time equivalent (FTE) positions that result from direct and indirect construction labor income,

$A_{\text {induced }}=$ the regression function intercept parameter for induced employment given in Table B-2, and

$B_{\text {induced }}=$ the regression function slope parameter for induced employment in Table B-2.

\section{B.4. SUPPLIER SURVEY RESULTS AND MANUFACTURING EMPLOYMENT REGRESSION ANALYSIS}

The Bechtel supplier survey provides inputs for estimating the amount of indirect employment (new U.S. manufacturing jobs). A typical survey data set is shown in Table B-3. Four pump suppliers provided forecasts of the number of U.S. jobs to be added to their payroll given the expected build out of nuclear power plants. They job categories were Manufacturing Trades (M), Engineering (E), Quality Assurance and Control (Q), Shipping and Receiving (S), Field Support (F), and Other (O). 
Table B-3. Supplier Survey Data for Pumps

\begin{tabular}{|c|c|c|c|c|c|c|c|c|c|c|c|c|c|c|c|c|}
\hline & & & Year & & & & & & & & & & & & & \\
\hline Company & $\begin{array}{l}\text { Market } \\
\text { Share }\end{array}$ & Category & '09 & ' 10 & '11 & '12 & ' 13 & ' 14 & ' 15 & ' 16 & '17 & ' 18 & '19 & '20 & '21 & '22 \\
\hline \multirow{6}{*}{ A } & \multirow{6}{*}{0.08} & $\mathrm{M}$ & 0 & 3 & 3 & 12 & 9 & 3 & 0 & 10 & 0 & 7 & 0 & 0 & 0 & 0 \\
\hline & & $E$ & 6 & 5 & 3 & 2 & 2 & 0 & 2 & 0 & 0 & 0 & 0 & 0 & 0 & 0 \\
\hline & & Q & 2 & 2 & 2 & 1 & 1 & 0 & 0 & 0 & 0 & 0 & 0 & 0 & 0 & 0 \\
\hline & & $\mathrm{S}$ & 0 & 2 & 2 & 1 & 0 & 1 & 0 & 0 & 0 & 0 & 0 & 0 & 0 & 0 \\
\hline & & $\mathrm{F}$ & 0 & 0 & 0 & 0 & 1 & 2 & 1 & 1 & 1 & 0 & 0 & 0 & 0 & 0 \\
\hline & & $\mathrm{O}$ & 7 & 7 & 6 & 6 & 7 & 0 & 1 & 0 & 0 & 0 & 0 & 0 & 0 & 0 \\
\hline \multirow{6}{*}{ B } & \multirow{6}{*}{0.25} & $\mathrm{M}$ & 10 & 0 & 0 & 0 & 0 & 0 & 0 & 0 & 0 & 0 & 0 & 0 & 0 & 0 \\
\hline & & E & 2 & 0 & 0 & 0 & 0 & 0 & 0 & 0 & 0 & 0 & 0 & 0 & 0 & 0 \\
\hline & & $\mathrm{Q}$ & 6 & 0 & 0 & 0 & 0 & 0 & 0 & 0 & 0 & 0 & 0 & 0 & 0 & 0 \\
\hline & & S & 0 & 0 & 0 & 0 & 0 & 0 & 0 & 0 & 0 & 0 & 0 & 0 & 0 & 0 \\
\hline & & $\mathrm{F}$ & 2 & 0 & 0 & 0 & 0 & 0 & 0 & 0 & 0 & 0 & 0 & 0 & 0 & 0 \\
\hline & & $\mathrm{O}$ & 0 & 0 & 0 & 0 & 0 & 0 & 0 & 0 & 0 & 0 & 0 & 0 & 0 & 0 \\
\hline \multirow{6}{*}{$\mathrm{C}$} & \multirow{6}{*}{0.50} & $\mathrm{M}$ & 20 & 5 & 5 & 0 & 0 & 0 & 0 & 0 & 0 & 0 & 0 & 0 & 0 & 0 \\
\hline & & E & 8 & 2 & 0 & 0 & 0 & 0 & 0 & 0 & 0 & 0 & 0 & 0 & 0 & 0 \\
\hline & & $\mathrm{Q}$ & 4 & 0 & 0 & 0 & 0 & 0 & 0 & 0 & 0 & 0 & 0 & 0 & 0 & 0 \\
\hline & & S & 2 & 0 & 0 & 0 & 0 & 0 & 0 & 0 & 0 & 0 & 0 & 0 & 0 & 0 \\
\hline & & $\mathrm{F}$ & 5 & 0 & 0 & 0 & 0 & 0 & 0 & 0 & 0 & 0 & 0 & 0 & 0 & 0 \\
\hline & & $\mathrm{O}$ & 2 & 0 & 0 & 0 & 0 & 0 & 0 & 0 & 0 & 0 & 0 & 0 & 0 & 0 \\
\hline \multirow{6}{*}{ D } & \multirow{6}{*}{0.30} & $\mathrm{M}$ & 10 & 0 & 10 & 0 & 0 & 0 & 0 & 0 & 0 & 0 & 0 & 0 & 0 & 0 \\
\hline & & $\mathrm{E}$ & 15 & 0 & 0 & 0 & 0 & 0 & 0 & 0 & 0 & 0 & 0 & 0 & 0 & 0 \\
\hline & & Q & 5 & 0 & 5 & 0 & 0 & 0 & 0 & 0 & 0 & 0 & 0 & 0 & 0 & 0 \\
\hline & & S & 2 & 0 & 0 & 0 & 0 & 0 & 0 & 0 & 0 & 0 & 0 & 0 & 0 & 0 \\
\hline & & F & 5 & 0 & 0 & 0 & 0 & 0 & 0 & 0 & 0 & 0 & 0 & 0 & 0 & 0 \\
\hline & & $\mathrm{O}$ & 3 & 0 & 0 & 0 & 0 & 0 & 0 & 0 & 0 & 0 & 0 & 0 & 0 & 0 \\
\hline
\end{tabular}


A linear multiple regression analysis can be performed for each year's data to provided an estimate of the total number of jobs added to the pump industry. The multivariate model equation is

$$
\left[\begin{array}{c}
\mathbf{E}_{A} \\
\mathbf{E}_{B} \\
\mathbf{E}_{C} \\
\mathbf{E}_{D}
\end{array}\right]=\mathbf{X}\left[\begin{array}{c}
M \\
E \\
Q \\
S \\
F \\
O
\end{array}\right]
$$

where

$\mathbf{E}_{A}=$ the 6-dimensional vector of employment values for all 6 categories for supplier A, $\mathbf{E}_{B}=$ the 6-dimensional vector of employment values for all 6 categories for supplier B, $\mathbf{E}_{C}=$ the 6-dimensional vector of employment values for all 6 categories for supplier C, $\mathbf{E}_{D}=$ the 6-dimensional vector of employment values for all 6 categories for supplier D, $\mathrm{m}_{A}=$ the market share for supplier A,

$\mathrm{m}_{B}=$ the market share for supplier B,

$\mathrm{m}_{C}=$ the market share for supplier $\mathrm{C}$,

$\mathrm{m}_{D}=$ the market share for supplier D,

$\mathbf{X}=\left[\begin{array}{l}m_{A} \mathbf{I}_{6} \\ m_{B} \mathbf{I}_{6} \\ m_{C} \mathbf{I}_{6} \\ m_{D} \mathbf{I}_{6}\end{array}\right]$, the design matrix of the data points for suppliers A, B, C, and D,

$\mathbf{I}_{6}=$ the $6 \times 6$ identity matrix,

$M=$ the total number of new Manufacturing Trades jobs in the pump industry,

$E=$ the total number of new Engineering jobs in the pump industry,

$Q=$ the total number of new Quality Assurance and Control jobs in the pump industry,

$S=$ the total number of new Shipping and Receiving jobs in the pump industry,

$F=$ the total number of new Field Support jobs in the pump industry, and

$O=$ the total number of new Other jobs in the pump industry. 
The value of $[M, E, Q, S, F O]$ is estimated using least squares. If the sum of the market shares

$$
\mathrm{m}_{A}+\mathrm{m}_{B}+\mathrm{m}_{C}+\mathrm{m}_{D}
$$

is greater than $100 \%$ then the estimates for $[M, E, Q, S, F, O]$ must be multiplied by

$$
1 /\left(\mathrm{m}_{A}+\mathrm{m}_{B}+\mathrm{m}_{C}+\mathrm{m}_{D}\right)
$$

to be valid. If the total market share from the supplier survey is less than $100 \%$, no adjustment of the estimates is necessary. Using this multivariate linear regression model, the '09 estimates for $[M, E, Q, S$, $F O]$ in the pump industry are as shown in Table B-4.

Table B-4. Pump Industry New Jobs Estimates for '09

\begin{tabular}{|c|c|}
\hline $\mathrm{O}$ & 6.02 \\
\hline $\mathrm{F}$ & 11.01 \\
\hline $\mathrm{S}$ & 3.91 \\
\hline $\mathrm{Q}$ & 12.62 \\
\hline $\mathrm{E}$ & 23.18 \\
\hline $\mathrm{M}$ & 37.91 \\
\hline Unadjusted Total New Jobs in Pump Industry & 94.64 \\
\hline Adjusted Total for Market Share Over 100\% & 83.76 \\
\hline
\end{tabular}

We use general linear model theory [Johnston, pp. 152-155] to develop statistical distributions for performing Monte Carlo analysis for manufacturing job estimates. To derive the statistical distribution for total jobs in a given industry, let

$$
\mathbf{c}=\left[\begin{array}{l}
1 \\
1 \\
1 \\
1 \\
1 \\
1
\end{array}\right]
$$

and let

$$
\hat{\boldsymbol{\beta}}=\left[\begin{array}{c}
\mathbf{O} \\
\mathbf{F} \\
\mathbf{S} \\
\mathbf{Q} \\
\mathbf{E} \\
\mathbf{M}
\end{array}\right]
$$


the vector of estimated new jobs. The statistic

$$
t_{n-6}=\frac{\mathbf{c}^{T} \hat{\boldsymbol{\beta}}-\mathbf{c}^{T} \boldsymbol{\beta}}{s \sqrt{\mathbf{c}^{T}\left(\mathbf{X}^{T} \mathbf{X}\right)^{-1} \mathbf{c}}}
$$

is distributed as Student's $t$ with n-6 degrees of freedom where

$\beta=$ the true value of regression parameters,

$\hat{\boldsymbol{\beta}}=$ the best fit value of regression parameters,

$n=$ the number of data points used to perform the regression,

$\mathbf{c}=\mathrm{a}$ 6-dimensonal vector of one's that defines the total jobs estimate for which we are computing statistics,

$\mathbf{X}=$ the design matrix of the data points used to perform the regression, and

$s=$ the estimate of the standard error estimate for the observation error from the regression.

Solving 0 for the total job estimate,

$$
\begin{aligned}
\mathbf{c}^{T} \boldsymbol{\beta} & =\mathbf{c}^{T} \hat{\boldsymbol{\beta}}+t_{n-6} s \sqrt{\mathbf{c}^{T}\left(\mathbf{X}^{T} \mathbf{X}\right)^{-1} \mathbf{c}}=\mathbf{c}^{T} \hat{\boldsymbol{\beta}}+t_{n-6} \sigma \\
& =\text { Total }+t_{n-6} s \sqrt{\mathbf{c}^{T}\left(\mathbf{X}^{T} \mathbf{X}\right)^{-1}} \mathbf{c}=\mathbf{c}^{T} \hat{\boldsymbol{\beta}}+t_{n-6} \sigma
\end{aligned}
$$

where

$$
\sigma=s \sqrt{\mathbf{c}^{T}\left(\mathbf{X}^{T} \mathbf{X}\right)^{-1} \mathbf{c}}
$$

the t-statistic scale parameter, and

$$
\text { Total }=\mathbf{c}^{T} \hat{\boldsymbol{\beta}}
$$

the estimate of total manufacturing jobs for a given year for a given commodity. Table B-5 below shows the values for these parameters based on the Bechtel survey data. Commodites that have no entry in the tstatistic scale parameter row have a survey response from only one supplier, in which case there is insufficient data to calculate a t-statistic scale parameter. 
Table B-5. Manufacturing Jobs by Commodity - Total Estimate and t-Statistic Scale Parameter

\begin{tabular}{|c|c|c|c|c|c|c|c|c|c|c|c|c|c|c|c|}
\hline & & ‘09 & '10 & ‘11 & '12 & '13 & ‘ 14 & ' 15 & '16 & '17 & '18 & ‘19 & '20 & '21 & '22 \\
\hline \multirow{2}{*}{ Concrete, Cement, and Reinforcing Steel } & Total & 1200.0 & 253.5 & 267.3 & 267.3 & 279.2 & 291.1 & 227.7 & 227.7 & 227.7 & 227.7 & 227.7 & 227.7 & 0.0 & 0.0 \\
\hline & $\sigma$ & 67.2 & 99.8 & 158.6 & 158.6 & 213.1 & 268.3 & 19.9 & 19.9 & 19.9 & 19.9 & 19.9 & 19.9 & 0.0 & 0.0 \\
\hline \multirow{2}{*}{ Condensers } & Total & 216.7 & 116.7 & 116.7 & 116.7 & 0.0 & 0.0 & 0.0 & 0.0 & 0.0 & 0.0 & 0.0 & 0.0 & 0.0 & 0.0 \\
\hline & $\sigma$ & & & & & & & & & & & & & & \\
\hline \multirow{2}{*}{ Control Valves } & Total & 290.8 & 290.8 & 290.8 & 290.8 & 150.8 & 150.8 & 150.8 & 150.8 & 150.8 & 150.8 & 32.3 & 32.3 & 32.3 & 32.3 \\
\hline & $\sigma$ & 80.9 & 80.9 & 80.9 & 80.9 & 42.6 & 42.6 & 42.6 & 42.6 & 42.6 & 42.6 & 13.8 & 13.8 & 13.8 & 13.8 \\
\hline \multirow{2}{*}{ Cranes } & Total & 126.9 & 219.2 & 355.4 & 515.0 & 711.5 & 202.7 & 202.7 & 202.7 & 202.7 & 202.7 & 202.7 & 194.5 & 194.5 & 194.5 \\
\hline & $\sigma$ & 29.3 & 57.5 & 74.9 & 69.8 & 85.1 & 99.8 & 99.8 & 99.8 & 99.8 & 99.8 & 99.8 & 5.5 & 5.5 & 5.5 \\
\hline \multirow{2}{*}{ Diesel Generators } & Total & 3.1 & 20.3 & 3.1 & 4.6 & 4.6 & 5.8 & 5.8 & 5.8 & 5.8 & 5.8 & 0.9 & 0.9 & 0.9 & 0.9 \\
\hline & $\sigma$ & 20.0 & 19.9 & 20.0 & 29.8 & 29.8 & 37.2 & 37.2 & 37.2 & 37.2 & 37.2 & 4.3 & 4.3 & 4.3 & 4.3 \\
\hline \multirow{2}{*}{ Fans } & Total & 58.0 & 66.0 & 66.0 & 10.0 & 66.0 & 10.0 & 10.0 & 66.0 & 10.0 & 10.0 & 10.0 & 0.0 & 0.0 & 0.0 \\
\hline & $\sigma$ & & & & & & & & & & & & & & \\
\hline \multirow{2}{*}{ Heat Exchangers } & Total & 1.9 & 113.3 & 214.2 & 241.3 & 273.3 & 252.3 & 252.3 & 322.1 & 322.1 & 322.1 & 322.1 & 324.8 & 0.0 & 0.0 \\
\hline & $\sigma$ & 2.7 & 42.8 & 54.1 & 28.0 & 16.4 & 142.1 & 142.1 & 188.9 & 188.9 & 188.9 & 188.9 & 188.9 & 0.0 & 0.0 \\
\hline \multirow{2}{*}{ Pipe } & Total & 316.5 & 100.0 & 100.0 & 100.0 & 100.0 & 100.0 & 100.0 & 100.0 & 100.0 & 100.0 & 100.0 & 100.0 & 100.0 & 100.0 \\
\hline & $\sigma$ & 63.4 & 44.9 & 44.9 & 44.9 & 44.9 & 44.9 & 44.9 & 44.9 & 44.9 & 44.9 & 44.9 & 44.9 & 44.9 & 44.9 \\
\hline \multirow{2}{*}{ Prefabricated Equipment Modules } & Total & 1125.0 & 0.0 & 0.0 & 0.0 & 0.0 & 0.0 & 0.0 & 0.0 & 0.0 & 0.0 & 0.0 & 0.0 & 0.0 & 0.0 \\
\hline & $\sigma$ & & & & & & & & & & & & & & \\
\hline \multirow{2}{*}{ Pumps } & Total & 83.8 & 10.9 & 17.9 & 3.8 & 3.5 & 1.0 & 0.7 & 1.9 & 0.2 & 1.2 & 0.0 & 0.0 & 0.0 & 0.0 \\
\hline & $\sigma$ & 33.0 & 8.7 & 12.0 & 10.9 & 9.4 & 3.0 & 2.0 & 8.0 & 0.8 & 5.6 & 0.0 & 0.0 & 0.0 & 0.0 \\
\hline \multirow{2}{*}{ Structural Steel } & Total & 1568.0 & 928.0 & 1568.0 & 624.0 & 960.0 & 1568.0 & 928.0 & 1568.0 & 624.0 & 1872.0 & 0.0 & 0.0 & 0.0 & 0.0 \\
\hline & $\sigma$ & 1323.6 & 440.7 & 721.1 & 280.9 & 440.9 & 1323.6 & 440.7 & 721.1 & 280.9 & 1164.2 & 0.0 & 0.0 & 0.0 & 0.0 \\
\hline \multirow{2}{*}{ Tanks (Field Erected) } & Total & 16.0 & 12.0 & 32.0 & 36.0 & 40.0 & 36.0 & 0.0 & 0.0 & 0.0 & 0.0 & 0.0 & 0.0 & 0.0 & 0.0 \\
\hline & $\sigma$ & & & & & & & & & & & & & & \\
\hline \multirow{2}{*}{ Tanks (Shop Fabricated) } & Total & 25.4 & 18.5 & 20.1 & 19.5 & 18.3 & 18.1 & 17.1 & 17.1 & 17.1 & 17.1 & 17.1 & 17.1 & 17.1 & 17.1 \\
\hline & $\sigma$ & 4.0 & 3.9 & 9.9 & 9.5 & 3.8 & 3.7 & 2.1 & 2.1 & 2.1 & 2.1 & 2.1 & 2.1 & 2.1 & 2.1 \\
\hline \multirow{2}{*}{ Turbine Generator Sets } & Total & 0.0 & 0.0 & 0.0 & 15.1 & 30.2 & 30.2 & 30.2 & 45.2 & 45.2 & 45.2 & 45.2 & 75.4 & 45.2 & 45.2 \\
\hline & $\sigma$ & 7.9 & 0.0 & 7.9 & 12.7 & 17.3 & 17.3 & 16.6 & 26.2 & 26.2 & 26.2 & 26.2 & 48.4 & 26.2 & 26.2 \\
\hline
\end{tabular}




\begin{tabular}{|c|c|c|c|c|c|c|c|c|c|c|c|c|c|c|c|}
\hline & & '09 & ' 10 & ' 11 & ' 12 & '13 & ' 14 & ' 15 & ' 16 & ' 17 & ' 18 & ' 19 & '20 & '21 & '22 \\
\hline \multirow{2}{*}{ Valves } & Total & 648.2 & 1239.2 & 619.6 & 0.0 & 623.5 & 619.6 & 619.6 & 619.6 & 0.0 & 0.0 & 0.0 & 0.0 & 0.0 & 0.0 \\
\hline & $\sigma$ & 43.1 & 113.2 & 56.6 & 0.0 & 56.6 & 56.6 & 56.6 & 56.6 & 0.0 & 0.0 & 0.0 & 0.0 & 0.0 & 0.0 \\
\hline \multirow{2}{*}{ Specialty Valves } & Total & 2.9 & 0.0 & 5.7 & 0.0 & 8.6 & 0.0 & 0.0 & 0.0 & 0.0 & 0.0 & 0.0 & 0.0 & 0.0 & 0.0 \\
\hline & $\sigma$ & & & & & & & & & & & & & & \\
\hline \multirow{2}{*}{ Water Treatment Plants } & Total & 566.7 & 566.7 & 566.7 & 566.7 & 0.0 & 0.0 & 0.0 & 0.0 & 0.0 & 0.0 & 0.0 & 0.0 & 0.0 & 0.0 \\
\hline & $\sigma$ & & & & & & & & & & & & & & \\
\hline
\end{tabular}




\section{B.5. NUCLEAR PLANT CONSTRUCTION}

\section{B.5.1 Construction project of the new nuclear power plant unit}

In the United States electricity consumption continues to increase, and aged coal-fired power plants will be retired. New nuclear power plant unit increases new production capacity of electricity needed by shareholders. This section outlines the processes, and the background employment figures are somewhat defined; However, the refinement of these activities in the permitting and planning stages are not captured in this study but will be refined in follow-on efforts.

The impact on the environment concerning a planned nuclear power plant unit is examined prior to the handling of the Decision in Principle, as prescribed by law. In the feasibility study, special attention is paid to safety, reliability, and cost effectiveness viability with assessments made for alternative plant sites/designs. The plant and its location will be chosen after evaluation and review by the NRC and State and Local governments. Extensive reviews and hearings are held which causes additional job creation. This process takes approximately 5 years. Employment activities of this sort are not captured in this report.

\section{B.5.1.1 Construction Permit / Licensing}

As prescribed by the NRC, permitting is then applied for the chosen plant unit and its location. The construction work can be started only when the construction permit has been granted. The second, or bidding, phase occurs after the application for a construction permit, as required by the NRC, is approved. The construction license process is estimated to take about four years. During that time, the contractor can carry out preliminary construction work at the chosen plant site. The construction of the plant unit will be started after granting of the construction permit.

The procurement of long-lead equipment will need to begin about 3 years before plant construction. At the phase when bids received from the suppliers are being evaluated, project personnel comprise from 20 to 30 persons. At the implementation phase, the number of the project personnel will grow from 60 to 100 persons. After the selection of the plant site, the project activities will be moved onto the selected plant site.

The cost of the new nuclear power plant is estimated from the plant capacity. Shareholders will provide the needed proportion of equity. The type of work to be carried out at the construction site of the new nuclear power plant unit generally corresponds to the erection and installation work at large-scale industrial and power plant construction sites. The long construction period and the large size of the construction project are considered special features. In addition, higher-than-normal quality standards as well as extensive regulatory control and supervision are adopted on the construction of a nuclear power plant.

\section{B.5.1.2 On-Site Work}

The new unit's construction and preparation work will take from five to six years. Depending on the construction process, approximately 2,000 people will participate in the construction and installation work. The on-site work will be mainly concentrated at the new plant site and its vicinity.

At the initial phase, most construction work consists of leveling and excavating. The following phase comprises the construction work of the power plant buildings. The installation of equipment is carried out later. 
The intention is to make the construction period shorter by using so-called modular construction (i.e., larger parts and entities are built elsewhere and transferred to the site when completed). Transports under the construction period as well as commuting to work will increase the amount of traffic directed to the power plant site by nearly two thousand vehicles a day. Construction materials, equipment, and components are transported to the power plant by road. The number of deliveries of goods and service will also grow during construction. Some contractors may use their caravans as accommodation facilities at the site. However, most contractors will probably take lodging in the surroundings of the plant site. The temporary labor needed for the large construction project will stimulate life in the densely built-up neighboring areas, increasing the need for services. These economic impacts have been excluded from this study.

\section{B.5.1.3 Subcontractors}

The choice of subcontractors is primarily affected by the companies' ability to compete with prices and their desire to contribute to supplies, thus fulfilling the quality and know-how requirements set for nuclear power plant construction. Although the plant unit's most significant parts, such as the reactor, the turbine and the generator, will be delivered by the plant vendor, the construction of the power plant also offers great subcontracting possibilities for smaller suppliers of engineering, services, and equipment.

The power plant project includes a considerable amount of subcontracted chained services as the plant supplier is primarily in contact with large engineering firms, workshops, and other companies. These, for their part, have contacts with smaller companies in their field. In addition to the price, the principal selection criteria for subcontracted procurements are, for example, complying with the required standards, previous procurement relations, location, and co-operation readiness required by deliveries that include special demands.

These subcontractors' employment numbers are not part of this original study.

\section{B.5.1.4 Impact on Employment and Economy}

The construction of the new nuclear power plant unit will have a direct impact on the economy and employment due to new jobs and demand resulting from construction. Companies that are to meet the growing demand resulting from construction will need goods and services from other companies and will thus form a procurement chain having indirect impact on economy. In addition to the direct and indirect impact, the investments will have an induced economic impact when the income from the production growth will be consumed thus increasing demand.

The new nuclear power plant unit would offer new permanent jobs for $150-200$ persons. In addition, during the annual refueling and maintenance shutdown periods, the plant will employ nearly 1,000 employees. As the amount of labor at the nuclear power plant increases, new services will be needed in the area. Increased demand from services will stimulate the commercial and industrial life of the site municipality and its vicinity, creating new indirect jobs.

The construction of the new nuclear power plant unit will have an influence on the development of the tax income of the site municipality via personal and real estate taxes. The annual real estate tax paid for the new plant unit after its completion is not part of this study; however, it will be part of the followon study. 


\section{B.5.1.5 Staff Development During Construction}

The construction and testing phase of the plant is the ideal time to hire and train staff, as well as to gain valuable knowledge in plant operation. Many of the plant departments will begin staffing during latter stages of plant construction, but some will begin earlier.

Plant ownership by the operating company typically starts during the preoperational test phase of construction. During this phase, systems are accepted from the construction team, readied for operation, and tested to ensure that the installed system and components meet all required design objectives. Following testing, the systems are turned over to the plant owner, who accepts operational and maintenance responsibility.

Staffing of plants is largely a site-specific issue. The construction phase offers a unique opportunity for the permanent plant staff to learn the plant design and layout. Early hiring and integration of the permanent staff may require some additional expense, but has been found to be well worth the cost.

Strict safety regulations have been prescribed for nuclear power plants in the United States. Employment in this area are not captured in this preliminary study.

Figure B-2 shows a simplified schedule for permitting, design, construction, and startup of an advanced reactor for a typical single-unit plant. The model uses these time periods for development of a workforce to construct and be trained for operations. This figure was taken the Dominion constructability study \{Dominion, et al, May 27, 2004].

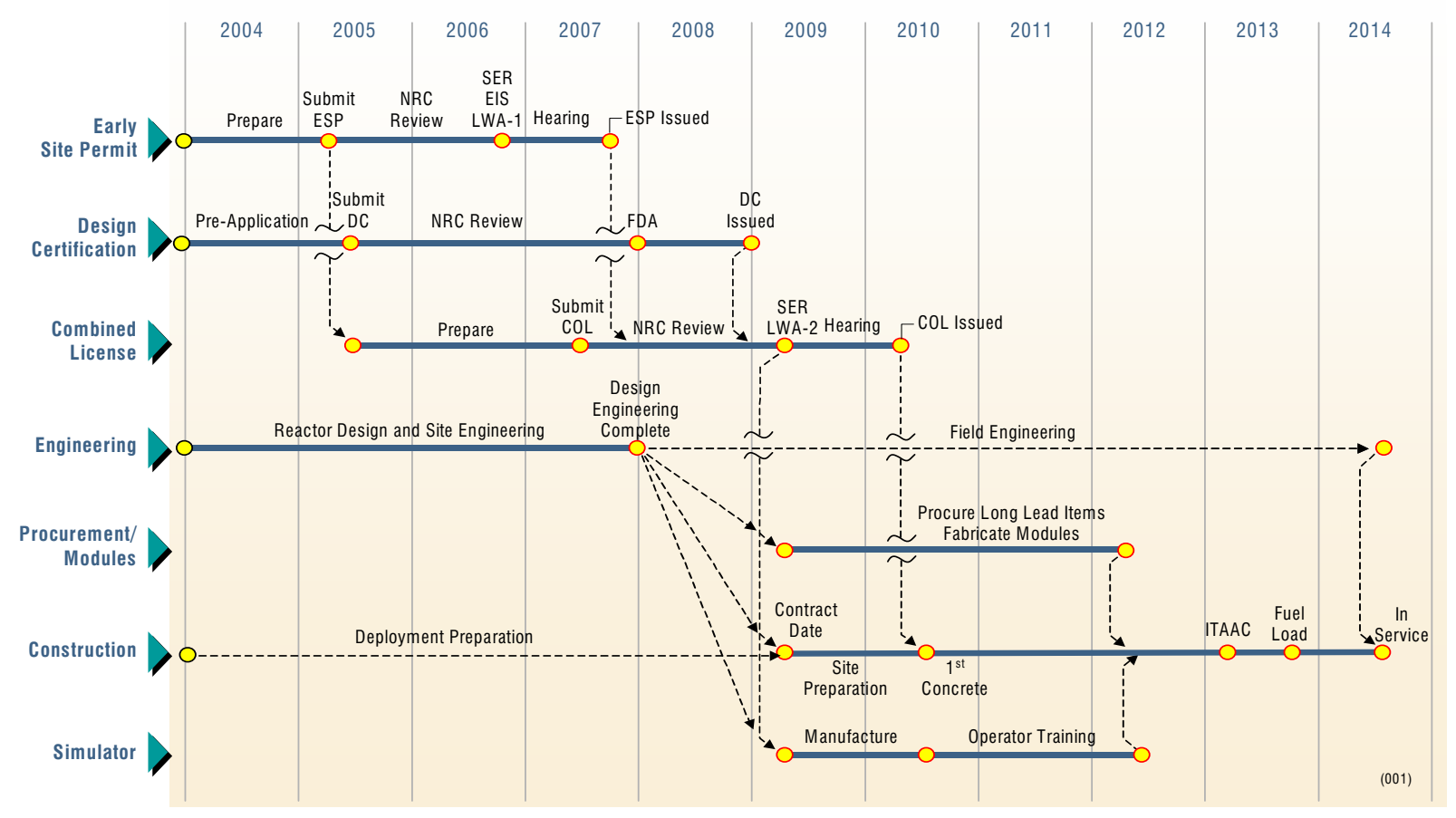

Figure B-2. Typical Plant Construction Schedule

For the first unit to be operating by 2014, the ramp-up for the construction staff would begin in 2009 and continue as follows: 
- The contract effective date to commercial operation is approximately 68 months.

- $\quad$ The ramp-up for the construction staff to support new nuclear plants would begin about 5 years prior to the start-up date for the new unit.

- $\quad$ Procurement of long lead items would begin on the contract effective date.

- $\quad$ Site preparation activities before first concrete will take approximately 18 months.

- $\quad$ The first concrete to fuel load duration is about 39 months.

- $\quad$ The duration from fuel load to commercial operation is about 7 months.

- Approximately 18 months is needed for plant simulator manufacture and delivery.

- 18 months is needed for operator training.

The availability of labor for new nuclear plant construction in the United States is a significant concern. Job growth for engineering, QA/QC, field support, etc. has not been evaluated as part of this study.

\section{B.5.1.6 Advanced Safety Technology}

Employment for external hazards threatening safety, such as extreme weather conditions, sabotage, and terrorism are not taken into account in this study.

\section{B.6. WASTE MANAGEMENT}

The nuclear Waste Management activities are excluded from this study; however, they may be considered as part of the future studies.

\section{B.7. REFERENCES}

1. Bechtel Power Corporation, Study of the Impact on Domestic Manufacturing and Supply Infrastructure Resulting from New Nuclear Plant Deployment, Revision A Draft, Frederick, Maryland, September 27, 2004

2. Dominion Energy Inc.; Bechtel Power Corporation; TLG, Inc. and MPR Associates, Study of Construction Technologies and Schedules, O\&M Staffing and Cost, Decommissioning Costs and Funding Requirements for Advanced Reactor Designs, Volume 1, United States Department of Energy Cooperative Agreement DE-FC07-03ID14492, Contract DE-AT01-020NE23476, May 27, 2004

3. Johnston, J., Econometric Methods, $2^{\text {nd }}$ Edition, McGraw-Hill Book Company, New York, New York, 1972.

4. Nuclear Energy Institute, Economic Benefits of Diablo Canyon Power Plant, Washington, DC, February 2004

5. Nuclear Energy Institute, Economic Benefits of Indian Point Energy Center, Washington, DC, April 2004 
6. Nuclear Energy Institute, Economic Benefits of Millstone Power Station, Washington, DC, July 2003

7. Nuclear Energy Institute, The Economic Benefits Of Oyster Creek Generating Station, Washington, DC, March 2004 


\section{Appendix C}




\section{Appendix C: Modeling Description \\ C.1. MODEL DESIGN}

A modular approach was used in the development of this model. This feature is useful when limiting the scope of the study to a single area, such as the current scope, but it is anticipated that the result of the first study would generate logical follow-on questions, for which the other modules can be used. Any of these modules can be run either in isolation or along with other modules.

The following modules have been created:

- Nuclear Power Plants

- Jobs

- Skilled Labor Availability

- Deactivation, Decommissioning and Decontamination (DD\&D)

\section{C.1.1 The Nuclear Power Plants Module}

The NPPs module accounts for all new orders, their stage in time (ordered, in construction and on-line). In addition, the current fleet of nuclear power plants is included to allow for a total power generating capacity count at any given time.

\section{C.1.2 The Jobs Module}

The Jobs module includes all the types of jobs considered in this study. Each type of job can be "switched on or off" to allow the model user to see the effects of new NPP orders on each type of job, annually and cumulative.

Although the original question for which this study was commissioned was related to the repatriation of jobs - largely

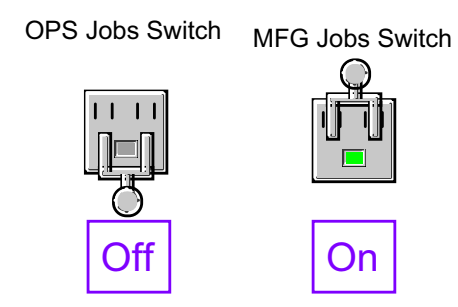
associated with the manufacturing sector - the intent of this model is to answer that question, yet allow for the expansion of the scope of the study including other types of jobs, which would also be generated as a result of placing orders for new NPPs. These other categories of jobs would not be considered "repatriated". However, their economic impact cannot be discounted as trivial or unrelated to the nuclear power industry expansion.

\section{C.1.3 Skilled Labor Availability Module}

To account for the pool of skilled labor available at any time, the current fleet is used as a seed from which to calculate the additional jobs created by the new orders and the replacement jobs generated by the retirement and, in general, attrition. The current pool is quickly becoming in short supply, due to its aging population and points to a strong reinstatement of educational programs, even without the generation of Kew jobs from new orders.

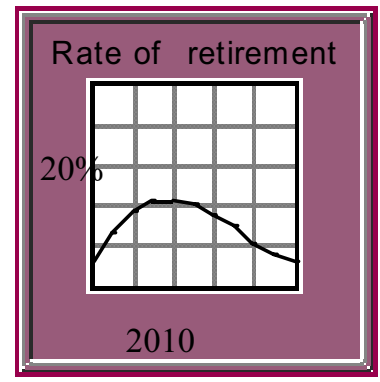




\section{C.1.4 The DD\&D Module}

Although the current fleet is expected to be operational for another $20+$ years ${ }^{1}$, it will eventually dwindle from the on-line rolls and will feed the DD\&D sector. This industrial sector may become rather large in its own right, prompting the development and application of new technologies, all of which carry an economic benefit.

\section{C.2. SOFTWARE}

Dynamic modeling tools are ideally suited to represent systems in which the results of certain activities feedback as inputs to the same equations they came from, defining the behavior of the system over time. One such tool is Stella ${ }^{\circledR}$ produced by ISEE Systems ${ }^{2}$ (formerly High Performance Systems). The ease of model building and its intuitive user interface makes Stella a strong candidate to build and present a first order model of the system. In spite of its "easy look and feel", Stella is replete with high-level functionality and advanced mathematics, inherent to any system where there is interdependence of the variables behind the icons on the screen.

The user interface allows for a quick readjustment of any independent variable to simulate different scenarios and observe the effect on the outcomes being sought. These changes in values are made through the use of "sliders" and "knobs", similar to those controls found
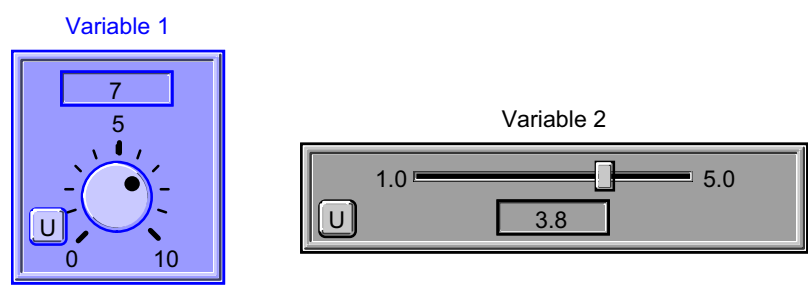
in everyday electronic devices.

Oftentimes, the value of a variable over time is defined by a predetermined set of conditions. In Stella, the model user can see the shape of this variable over time through graphs posted at the interface level, and can temporarily change it to any desired shape to observe the effect on the outcome. The original data remain in the model while the interface graph can simply be reset to match it.

Should there be a need in the future to change modeling software, Stella features an "export" function that allows the data to be

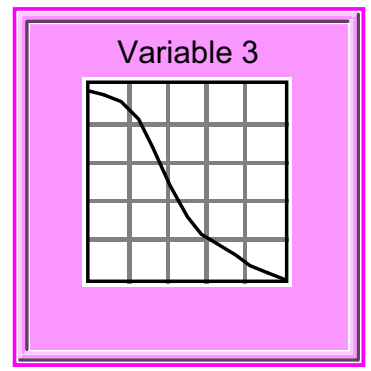
transferred to the new format.

\section{C.3. ASSUMPTIONS}

The general construct of the model is based on the following premises or assumptions:

1. The ordering of new nuclear power plants (NPPs) triggers demand for new jobs in several industrial sectors:

a. Direct (Manufacturing, Construction and Operations)

\footnotetext{
${ }^{1}$ Assumes life extension of 20 years beyond original shut down date.

${ }^{2}$ http://www.iseesystems.com
} 

b. Indirect (Services)
c. Induced (Affected community)

2. The timing for these job types relative to the time of the order varies:

a. Manufacturing jobs demand is created immediately, but it grows only to the point this industrial sector can satisfy the desired throughput (new orders per year), after which it stays level as long as the throughput remains constant

b. Construction jobs demand is also created at the same time the order is placed. However, the level at which it grows depends on the construction phase for each plant, the interval between orders, the ordering rate and the construction effort duration. Similar to the Manufacturing sector, the level of Construction jobs would reach steady-state conditions and would remain constant.

c. Operations jobs demand is also created with the ordering of new NPPs. However, it lags the order time by some time to allow for the installation of simulators in which to train. This type of job grows with the number of plants on-line and the demand is reduced only by the availability of skilled labor coming from a shutdown plant (from the current fleet). This reduction does not reach a non-zero value until 2024, since it is assumed the 20 -year extension is likely to be granted to those applying for it.

d. Indirect jobs demand (primarily technical services) is also triggered by the order of new plants, but it lags the order by a greater time than the Operations jobs (with the exception of training staff). These jobs, although not all are physically at the plant, are linked to the construction and operation of the plant and have an impact on the region where the plant is located and nationally.

e. Induced jobs are generated as a response to the increase in commercial activity that results from the expenditure of labor wages in the above categories and which occurs mostly beyond the region where the plant is located. The response time for the induced jobs is, therefore, coincident with the demand of the previous categories.

3. The number of jobs generated for each of the above categories varies according to the plant capacity and the number of plants ordered. These variables are brought together as Jobs per 1000 MWe capacity. 


\section{C.4. INDEPENDENT VARIABLES}

The model uses several independent variables as input to calculations to produce either intermediate results, used elsewhere, or the desired outputs. The independent variables are listed in Table C-1.

Table C-1. Independent Variables

\begin{tabular}{|c|c|c|}
\hline Variable Name & Description & Source \\
\hline MFG Jobs per NPP & $\begin{array}{l}\text { Jobs generated in the manufacturing sector } \\
\text { with every order of NPP }\end{array}$ & $\begin{array}{l}\text { Regression analysis of data } \\
\text { from Bechtel Power } \\
\text { Survey }\end{array}$ \\
\hline CONST Jobs per NPP & $\begin{array}{l}\text { Jobs generated in the construction sector with } \\
\text { every order of NPP }\end{array}$ & $\begin{array}{l}\text { Bechtel Power analysis of } \\
\text { Vision } 2020 \text { data }\end{array}$ \\
\hline OPS Jobs per NPP & $\begin{array}{l}\text { Jobs generated in the plant operations sector } \\
\text { with every order of NPP }\end{array}$ & $\begin{array}{l}\text { Regression analysis of data } \\
\text { from NEI Reports and } \\
\text { Dominion Report }\end{array}$ \\
\hline $\begin{array}{l}\text { INDIRECT Jobs per } \\
\text { Direct Job }\end{array}$ & $\begin{array}{l}\text { Jobs generated in the various sectors, } \\
\text { including technical services for every Direct } \\
\text { Job created }\end{array}$ & $\begin{array}{l}\text { Regression analysis of data } \\
\text { from NEI Reports }\end{array}$ \\
\hline $\begin{array}{l}\text { INDUCED Jobs per } \\
\text { Direct job }\end{array}$ & $\begin{array}{l}\text { Jobs generated in non-nuclear sectors, as a } \\
\text { result in increased commercial activity for } \\
\text { every Direct Job created }\end{array}$ & $\begin{array}{l}\text { Regression analysis of data } \\
\text { from NEI Reports }\end{array}$ \\
\hline New NPP Orders & Orders for new Nuclear Power Plants & $\begin{array}{l}\text { Bechtel Power analysis of } \\
\text { Vision } 2020 \text { data }\end{array}$ \\
\hline Plant Capacity & $\begin{array}{l}\text { The electric output in MWe of every new } \\
\text { power plant ordered }\end{array}$ & $\begin{array}{l}\text { Bechtel Power analysis of } \\
\text { Vision } 2020 \text { data }\end{array}$ \\
\hline Construction Time & Duration of the construction of a NPP & $\begin{array}{l}\text { Dominion report schedule } \\
\text { shown in Bechtel Power } \\
\text { survey }\end{array}$ \\
\hline $\begin{array}{l}\text { Lead Time (LT) for } \\
\text { MFG jobs }\end{array}$ & $\begin{array}{l}\text { The time it takes for the MFG jobs to be } \\
\text { created from the time the order is placed }\end{array}$ & $\begin{array}{l}\text { Dominion report schedule } \\
\text { shown in Bechtel Power } \\
\text { survey }\end{array}$ \\
\hline $\begin{array}{l}\text { Lead Time (LT) for } \\
\text { CONST jobs }\end{array}$ & $\begin{array}{l}\text { The time it takes for the CONST jobs to be } \\
\text { created from the time the order is placed }\end{array}$ & $\begin{array}{l}\text { Dominion report schedule } \\
\text { shown in Bechtel Power } \\
\text { survey }\end{array}$ \\
\hline $\begin{array}{l}\text { Lead Time (LT) for } \\
\text { OPS jobs }\end{array}$ & $\begin{array}{l}\text { The time it takes for the OPS jobs to be } \\
\text { created from the time the order is placed }\end{array}$ & $\begin{array}{l}\text { Dominion report schedule } \\
\text { in Bechtel Power survey }\end{array}$ \\
\hline $\begin{array}{l}\text { Lead Time (LT) for } \\
\text { INDIRECT jobs }\end{array}$ & $\begin{array}{l}\text { The time it takes for the INDIRECT jobs to be } \\
\text { created from the time the order is placed }\end{array}$ & $\begin{array}{l}\text { Dominion report schedule } \\
\text { in Bechtel Power survey }\end{array}$ \\
\hline $\begin{array}{l}\text { Lead Time }(\mathrm{LT}) \text { for } \\
\text { INDUCED jobs }\end{array}$ & $\begin{array}{l}\text { The time it takes for the INDUCED jobs to be } \\
\text { created from the time the order is placed }\end{array}$ & $\begin{array}{l}\text { Dominion report schedule } \\
\text { in Bechtel Power survey }\end{array}$ \\
\hline
\end{tabular}

\section{C.5. DESIRED OUTPUTS}

The answer to the original question of "how many jobs would be repatriated as a result of ordering new nuclear power plants in the US" is relatively easy to answer from the data obtained through the vendor/supplier survey performed by Bechtel Power. On the other hand, the value of 
the answer is then tied to the quality of the data obtained in that survey. A more dependable set of answers can be obtained by validating the data from the survey, using the findings from studies previously performed by MIT, University of Chicago, NEI and other credible institutions.

For this study, the model uses as inputs the independent variables listed above and uses the following general equation to calculate the desired outcomes:

The total New Jobs generated in any given year $\left(t_{i}\right)$ is described by:

$$
\text { New Jobs }\left(\mathrm{t}_{\mathrm{i}}\right)=[(\mathrm{MFG}+\text { CONST }+ \text { OPS }+ \text { INDIRECT }+ \text { INDUCED }) *(\mathrm{t}-\mathrm{dt})]
$$

As described above, the types of jobs have been equipped with an "on-off" switch, thus allowing the above equation to consider a zero or non-zero option for any and all job types.

The Cumulative value of New Jobs is simply the integration of the above equation over the time period considered:

$$
\text { Cumulative New Jobs }=\sum \text { New Jobs } * d t
$$

As the relationship between New Orders and New Jobs varies by job category and by the Lead Time (LT) for each job, the use of time-delayed functions is applied to those job categories, which have a non-zero value for their corresponding Lead Time. For example, MFG Jobs has no LT, whereas OPS Jobs has an LT of 1.5 years $^{3}$ and INDIRECT Jobs has an LT of 4 years.

A graphical representation of the model outputs is provided in Figure C-1 for NPPs in their varying stage since their order time.

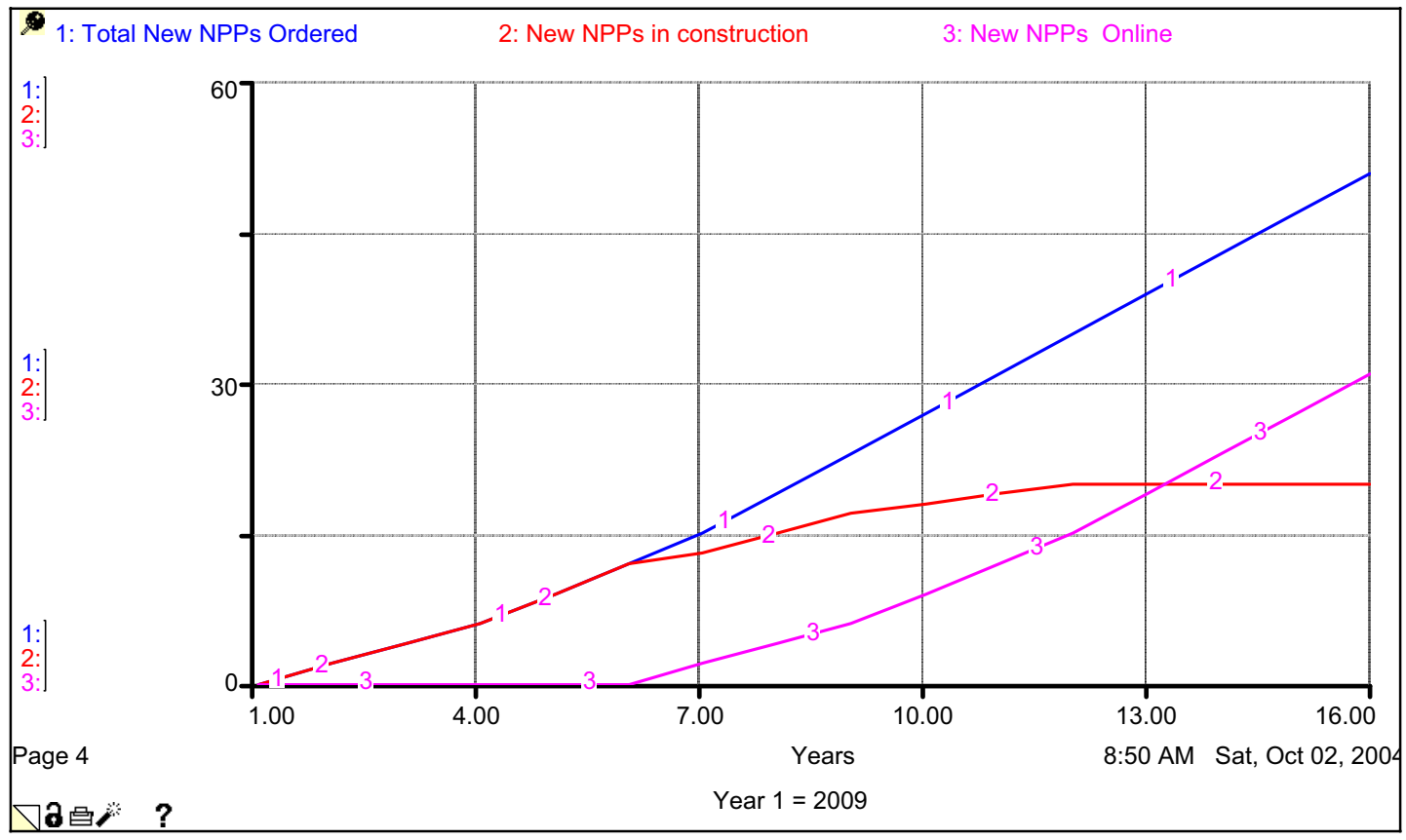

Figure C-1. Nuclear Power Plant Orders

\footnotetext{
${ }^{3}$ From order time
} 
Figure C-1 shows a simple representation of the number of NPPs ordered, in construction and on-line. Since the construction period is defined as 5 years, it is only at $t>5$ that we see a difference between NPPs ordered (line 1) and in construction (line 2). This is also the point at which the first NPP comes on-line (line 3).

Similarly, the model outputs for New Jobs in construction can be seen below in Figure C-2.

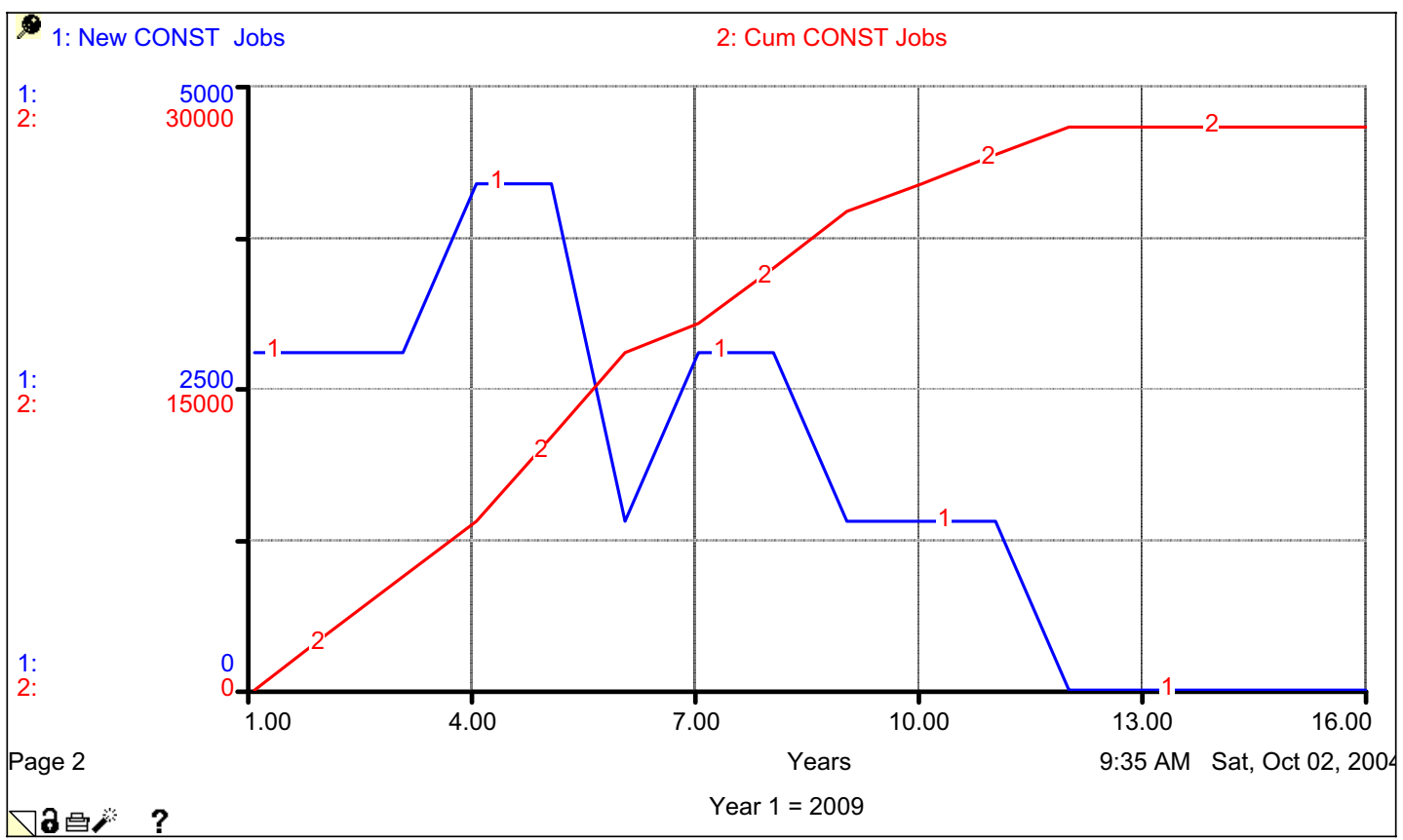

Figure C-2. Construction Jobs

The rate of increase (or new demand) in Construction jobs is greater in the first five years while orders continue to be placed and no plants have been finished. As plants go on-line, the construction crews move to the sites of those newly ordered plants, decreasing the new demand (line 1). When the rate of orders equals the rate of NPPs going on-line a steady-state condition reached and kept until the new orders rate changes. The Cumulative Construction Jobs (line 2) continues to climb up to that steady-state condition, at which time it maintains its value.

A similar result is obtained in the Manufacturing sector as shown in Figure C-3. 


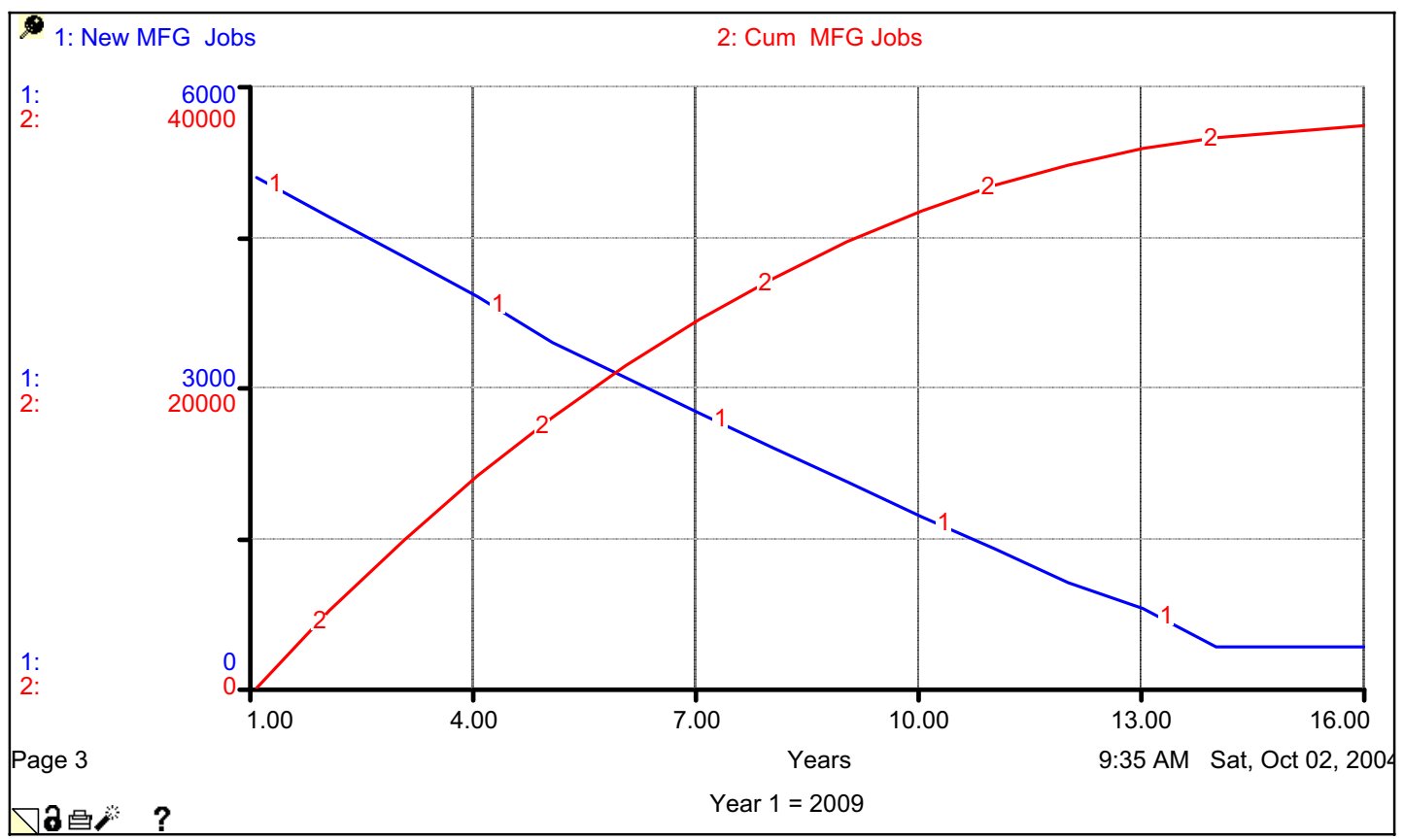

Figure C-3. Manufacturing Jobs

It should be noted that the "smooth" nature of the lines in Figure C-3 is due to the conversion of the raw data obtained in the Bechtel Power survey and the polynomial trend line obtained from it. New demand in the manufacturing sector is created with every new order. This added manufacturing capacity contributes to the total throughput capacity of this sector only to the point that the rate of orders for new plants becomes steady. At this time, the new demand is only nominal (and temporary), attributed to the idiosyncrasies of the sector itself (new tooling and manufacturing methods). This steady-state condition is represented by the Cumulative MFG Jobs (line 2) becoming nearly flat.

In the Plant Operations sector, the demand is simply proportional to the NPPs on-line as shown in Figure C-4. 


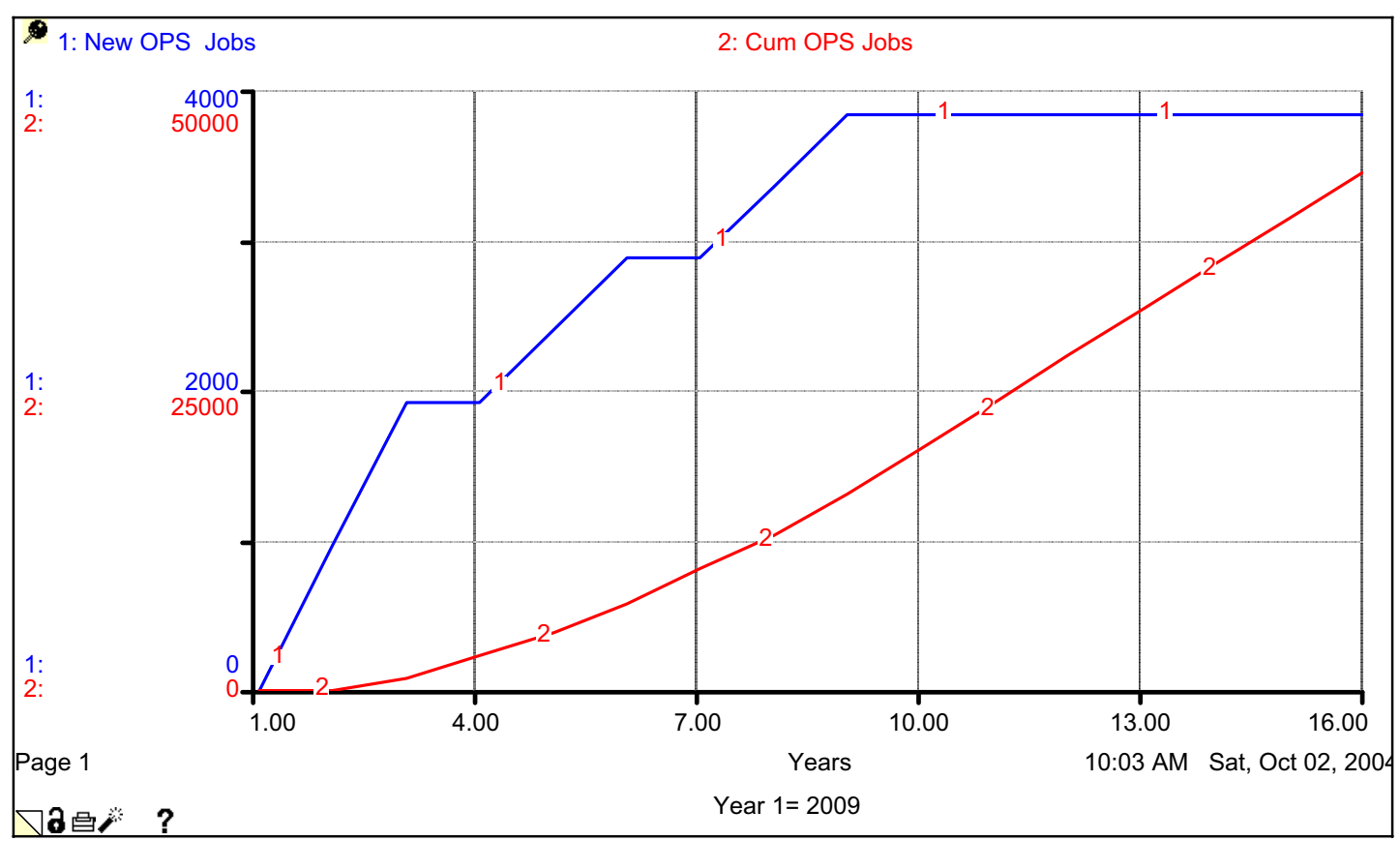

Figure C-4. Operations Jobs

Once the rate of new orders stabilizes, the demand for OPS Jobs (line 1 in Figure C-4) stays constant - and the Cumulative OPS Jobs (Line 2) keep the same slope.

The INDIRECT Jobs sector is calculated using inputs from the regression analysis performed on various reports from NEI. The number of OPS jobs is the input to the following equation:

$$
\text { INDIRECT Jobs/NPP }=5885.1-(\text { OPS Jobs/NPP)*1.63 }
$$

The graphical output of the model for INDIRECT Jobs as a function of OPS Jobs is shown in Figure C-5. 


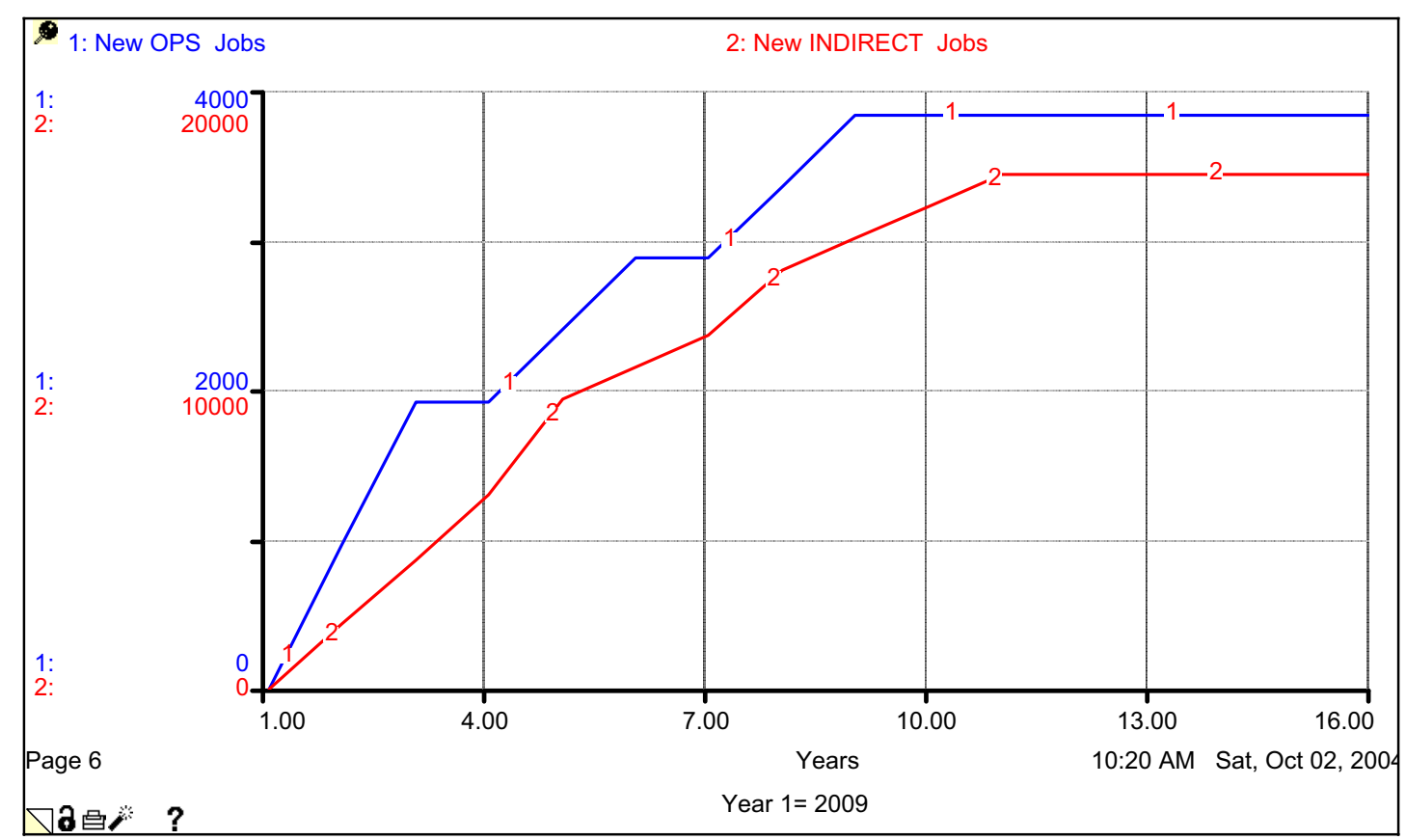

Figure C-5. Indirect Jobs and Operations Jobs.

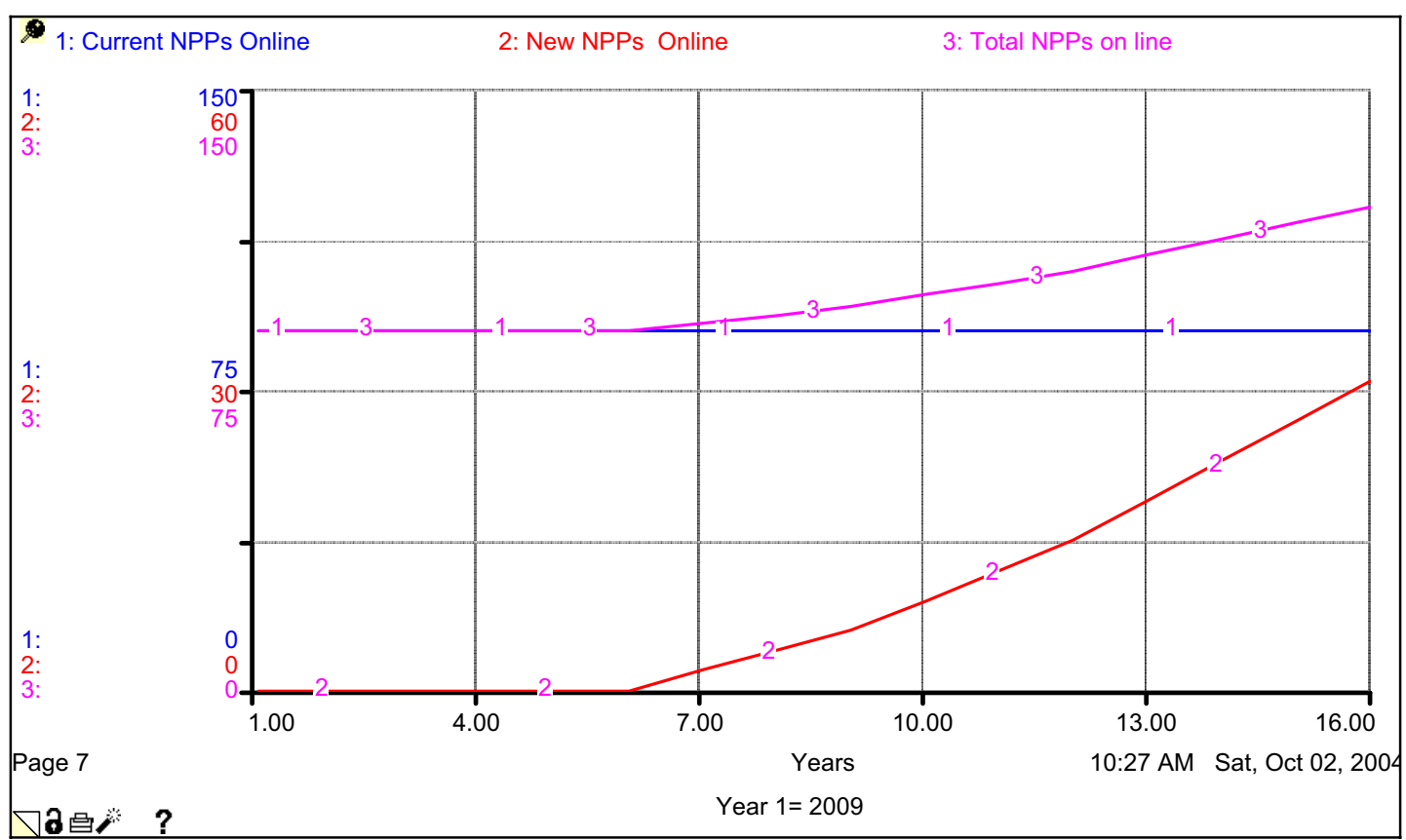

Figure C-6. New Power Plants Online by 2024.

Assuming all reactors in the current fleet obtain a 20 year life extension, the period of performance for this study does not allow seeing the impact of shut-downs on the total number of NPPs on-line, which is shown in Figure C-6 where the period of performance ends in 2024. However, if the period of performance is extended and the number of orders for NPPs is kept the same, the following results are obtained as shown in Figure C-7 


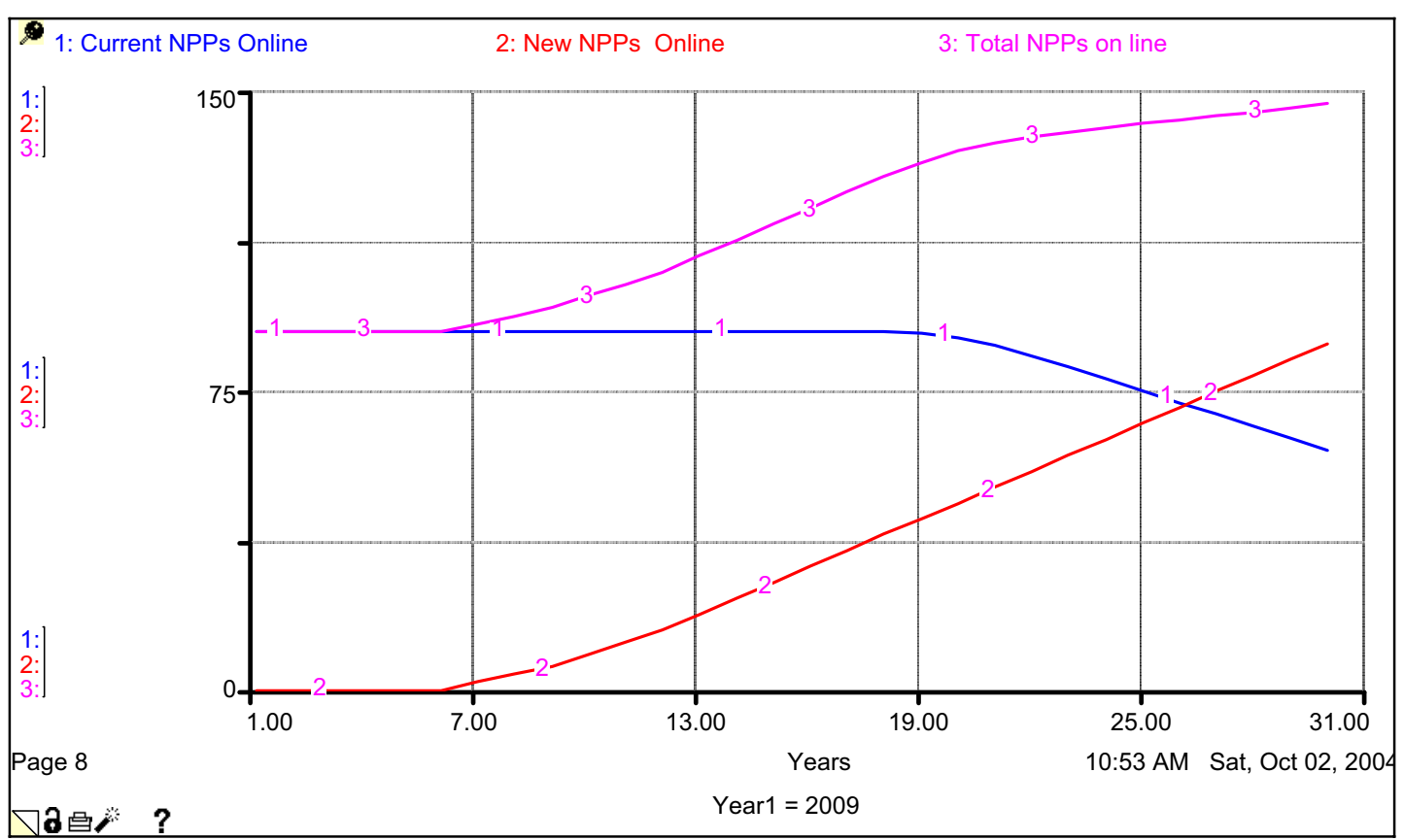

Figure C-7. New Power Plants Online by 2039.

Figure C-8 depicts the change in capacity, new, current and total, over a period of performance long enough to see some of the current fleet reactors under DD\&D.

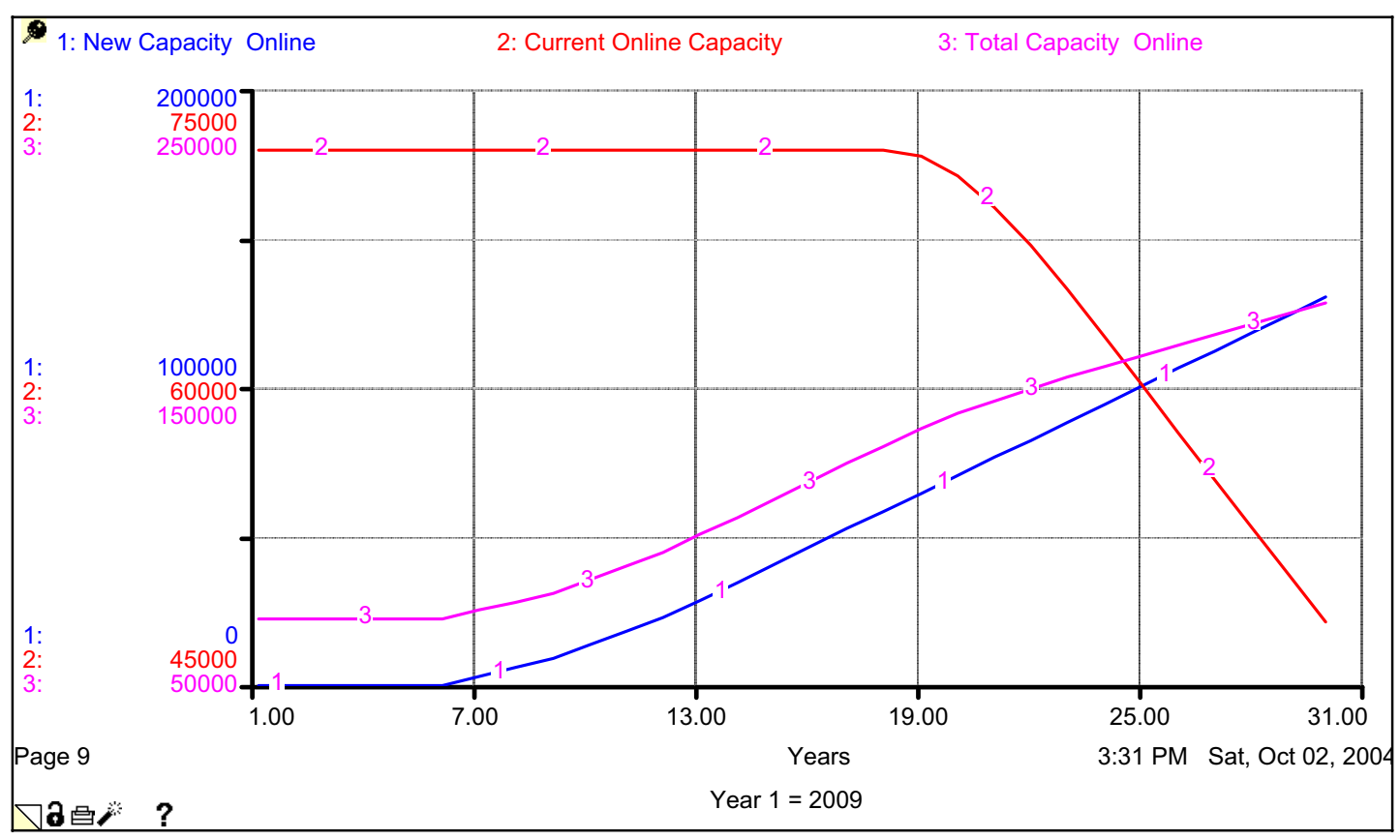

Figure C-8. Change in Capacity. 


\section{C.6. USER INTERFACE}

One of the features of the selected software package (Stella) that makes it ideal for "what if" scenarios is its Graphical User Interface. It is laid out as a control panel with knobs and sliders, typically assigned to the independent variables we want to evaluate and for which we provide different values.

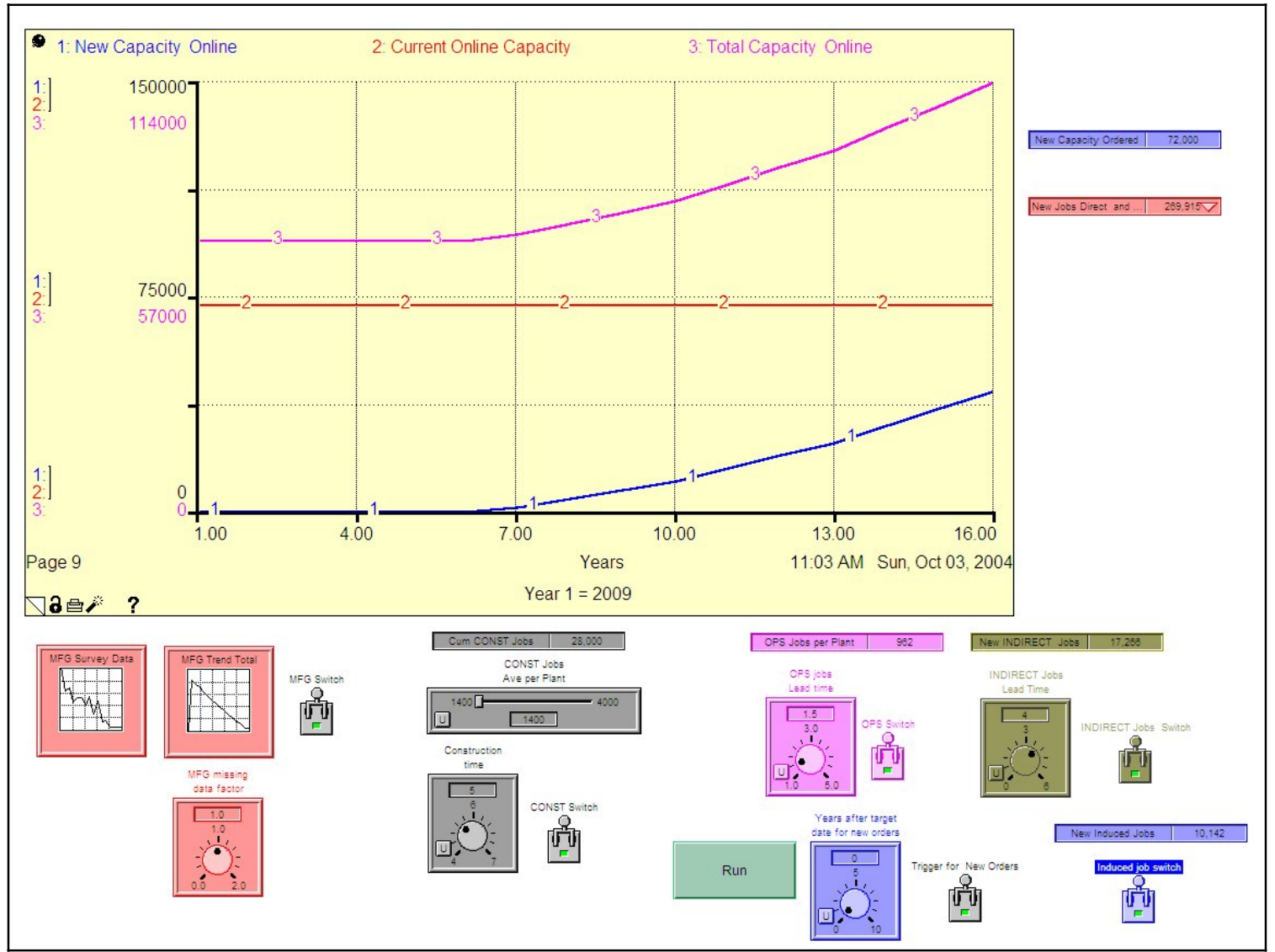

\section{C.7. MODEL EXPANSION}

The current model provides an answer to the original question and also offers some insights as to what other factors to consider in the estimation of the economic impact to the U.S. should the nuclear industry see a new dawn. However, the value of this type of model can be best appreciated when connecting some of its current outputs to decision frameworks related to the conditions that must be present for the resurgence of the nuclear power industry to take place. Some of these conditions listed in Table C-2. 
Table C-2. Conditions Necessary for a Resurgence of the Nuclear Power Industry Variable Name

Power purchase agreements

Tax abatements

Financial Risk Reduction

Federal Energy Credits

Spent Fuel Disposition (disposal or recycle)

Political Adversity

Public Acceptance

Affordability of alternative energy sources

Current cost of energy

$\begin{array}{ll}\text { If Present } & \text { Positive } \\ \text { If Present } & \text { Positive } \\ \text { If Present } & \text { Positive } \\ \text { If Present } & \text { Positive } \\ \text { If Present } & \text { Positive } \\ \text { If Present } & \text { Negative } \\ \text { If Present } & \text { Positive } \\ \text { If Present } & \text { Negative } \\ \text { If High } & \text { Positive }\end{array}$

The feedback loop that is established between the "Benefits from New Orders"" and "Government Initiatives" calls for a set of Favorable Conditions to be quantified and a minimum threshold set, below which no orders are expected.

Even if an accurate quantification of some of the "favorable conditions" is not possible, a first order approximation can be reached and additional insights gained when the integration of theses factors is first simulated. Typically, the first time a simulation is run with the model, the results point to a faulty (or biased) relationship and additional analysis - and discussion - takes place among the team members. Oftentimes, external validation is sought, which results in a better and simpler model.

Figure C-9. Interdependence Diagram

\footnotetext{
${ }^{4}$ Economic impact from wages and commercial activity (tax base, increased industrial output)
} 
Appendix D 


\section{Secretary of Energy Advisory Board /Department of Energy}

Job Growth Resulting from 50,000 MW of Added Capacity - Fossil vs. Nuclear Comparison

Bechtel Power Corp.

November 17, 2004

\section{Problem Statement:}

On October 12, 2004 a draft study was presented to the SEAB that indicated there would be 117,000 additional direct jobs added to the domestic economy resulting from the deployment of new nuclear plants in the U.S. through 2024. During presentation of study findings to the SEAB the following question was posed: "How do these jobs compare with the jobs that would be present without nuclear power" (e.g., the building of MW equivalent coal fired power plants)? In other words, what would be the impact on jobs if the 50,000 MWe were provide by coal fired power plants rather than new nuclear power plants?"

\section{Approach:}

1. We first identified several representative projects as references for this study in order to predict the new coal-fired power plant MW capacities.

2. Then we predicted the quantity of fossil craft jobs vs. nuclear craft jobs for the construction of these new coal fired power plants.

3. Finally, we reviewed historical data to determine a statistically relevant normalization factor such as headcount per MW or job hours per KW.

\section{Assumptions:}

1.) The similar manual labor resources as expended in the past will be required to construct the new coal fired and nuclear power plants in the future (no consideration of improvements in construction practices, productivity and efficiency has been included since no new nuclear plants have been constructed to serve as a benchmark).

2.) The new coal-fired power plants will have a 36-month schedule.

3.) As with the initial nuclear study the resource requirements for these new coal plants will all be considered to be "new" construction jobs above and beyond what is required to replace the aging fossil power plants that are in operation today.

\section{Discussion:}

Utilizing actual pulverized coal technology power plant Net Electrical Output data from historical sources we predicted the Net Electrical Output (size) of the typical future coal power plants. Utilizing Bechtel internal and industry information on coal fired power plant NEO's we concluded that there would be 3 general size ranges of coal fired power plants built in the future: $300 \mathrm{MW}, 600 \mathrm{MW}$, and $800 \mathrm{MW}$. It was necessary to determine the power plant sizes in order to predict the number of new construction jobs along with the indirect and induced jobs created by these new coal power plants. 
Based upon these plant sizes Table 1 below was developed to quantify the number of each of these plants required to achieve the $50,000 \mathrm{MW}$ installed generating capacity by the year 2024 (at a similar rate of additional MW capacity as that forecasted in the original report):

Table 1: Power Plant Quantity by Type \& Year

\begin{tabular}{|c|c|c|c|c|c|}
\hline Year & $\mathbf{1 2 0 0}$ MW Nuclear & $\mathbf{1 5 0 0}$ MW Nuclear & $\mathbf{3 0 0}$ MW Coal & $\mathbf{6 0 0}$ MW Coal & $\mathbf{8 0 0}$ MW Coal \\
\hline 2012 & 0 & 0 & 1 & 1 & 1 \\
\hline 2013 & 0 & 0 & 1 & 1 & 1 \\
\hline 2014 & 1 & 1 & 2 & 1 & 1 \\
\hline 2015 & 2 & 2 & 8 & 3 & 1 \\
\hline 2016 & 3 & 2 & 12 & 6 & 2 \\
\hline 2017 & 3 & 2 & 12 & 6 & 3 \\
\hline 2018 & 4 & 3 & 16 & 8 & 7 \\
\hline 2019 & 4 & 3 & 16 & 8 & 7 \\
\hline 2020 & 4 & 4 & 16 & 8 & 7 \\
\hline 2021 & 5 & 4 & 20 & 10 & 7 \\
\hline 2022 & 5 & 4 & 20 & 10 & 8 \\
\hline 2023 & 5 & 4 & 20 & 10 & 8 \\
\hline 2024 & 5 & 4 & 20 & 10 & 9 \\
\hline TOTAL Plants & $\mathbf{4 1}$ & $\mathbf{3 3}$ & $\mathbf{1 6 4}$ & $\mathbf{8 2}$ & $\mathbf{6 2}$ \\
\hline Total MW & $\mathbf{4 9 , 2 0 0} \mathbf{M W}$ & $\mathbf{4 9 , 5 0 0} \mathbf{M W}$ & $\mathbf{4 9 , 2 0 0} \mathbf{M W}$ & $\mathbf{4 9 , 2 0 0 M W}$ & $\mathbf{4 9 , 6 0 0 M W}$ \\
\hline
\end{tabular}

Utilizing construction labor data for coal-fired and nuclear power plant construction, ManYear/Megawatt values were determined. This methodology (calculating MY/MW) was employed in an attempt to quantify the construction resource requirements on a common basis without regard to facility size or technology.

\section{Conclusion}

Based on the plant type and sizes by year and comparing the differences in the magnitude of the total man-years per megawatt between the two technologies, we can approximate the differences between the new construction jobs created by nuclear and coal-fired power plants.

A ratio of: $\frac{\text { Man Years/MW (Cumulative) Coal }}{\text { Man Years/MW (Cumulative) Nuclear }}$ results in 0.56

for all cases and plant sizes reviewed. Therefore we can infer that 50,000 MW of coal power build out would require only $56 \%$ of the direct construction craft labor hours as compared to nuclear plant construction.

Contemporary construction productivity improvements are assumed to apply equally to new coal and new nuclear construction in the future. However, a quantity comparison between new generation nuclear plants and modern clean coal plants has not been evaluated in this analysis. There is potential growth in coal plant quantities resulting from clean coal initiatives that may increase the historical craft labor hours per MW, and there are potential reductions in nuclear plant quantities for new generation plants that may reduce the historical craft labor hours per MW. These factors should be considered and investigated in more detail in future phases of the study. 
Appendix E 


\section{Appendix E: Coal Plant Employment Impact Analyses}

The data available for clean coal plant employment impact analysis comes mostly from press releases or data provided by the Illinois Department of Commerce and Economic Opportunity. These data sources are usually quoting results provided by internal studies at the firms that plan to build and operate these plants. We analyzed the data available on clean coal plants and combined it with the results from nuclear plant analyses in Appendix B to determine the deterministic equations for expected jobs and probability distributions needed to simulate uncertainties.

\section{E.1 CLEAN COAL POWER PLANT PRODUCTION FUNCTION REGRESSION ANALYSIS}

We used the same relationship to be fit in the equation that relates plant capacity and plant direct employment as was used for nuclear plants. Using classical economic production models, we let

$$
E_{\text {direct }}=\alpha C^{\beta}
$$

where $E_{\text {direct }}$ is the direct employment at the plant, $C$ is the plant capacity in megawatts (MW), and $\alpha$ and $\beta$ are coefficients to be fit. Taking logarithms of 0 , we have

$$
\ln \left(E_{\text {direct }}\right)=\ln (\alpha)+\beta \ln (C)
$$

which was used as the linear model for a linear regression fit with all of the direct employment and capacity data collected from various sources.

The regression fit is done using data from Table E-1 below. Some of the reported direct plant employment data included mine workers at coal mines that adjoined the power plant, which were planned to be the sole source of fuel for the power plant. We adjusted this data to separate out the power plant jobs from mining jobs using the overall ratio of power plant jobs to the total number of power plant and mining jobs in other plants that provided separate totals for these two job categories.

\begin{tabular}{|c|c|c|c|c|c|c|}
\hline $\mathbf{i}$ & Plant Name & Data Source & $\mathbf{E}_{\text {direct }}$ & $\mathbf{C}_{\mathbf{i}}$ & $\ln \left(\mathbf{E}_{\text {direct }}\right)$ & $\ln (\mathbf{C})$ \\
\hline 1 & Elwood, IL Indeck & http://www.illinoisbiz.biz/coal/ProjectSummaries.html & 130 & 660 & 4.87 & 6.49 \\
\hline 2 & $\begin{array}{l}\text { Benton, IL } \\
\text { EnviroPower }\end{array}$ & http://www.illinoisbiz.biz/coal/ProjectSummaries.html & $91 *$ & 550 & 4.52 & 6.31 \\
\hline 3 & $\begin{array}{l}\text { Marissa, IL } \\
\text { Peabody }\end{array}$ & http://www.illinoisbiz.biz/coal/ProjectSummaries.html & $191^{*}$ & 1500 & 5.25 & 7.31 \\
\hline 4 & $\begin{array}{l}\text { Benton, IL } \\
\text { Franklin }\end{array}$ & http://www.illinoisbiz.biz/coal/ProjectSummaries.html & 180 & 1500 & 5.19 & 7.31 \\
\hline 5 & $\begin{array}{l}\text { Baldwin, IL } \\
\text { Dynegy }\end{array}$ & http://www.illinoisbiz.biz/coal/ProjectSummaries.html & 200 & 1,500 & 5.30 & 7.31 \\
\hline 6 & $\begin{array}{l}\text { Central City, KY } \\
\text { Peabody }\end{array}$ & The Evansville Courier \& Press, February 16, 2001 & 150 & 1500 & 5.01 & 7.31 \\
\hline
\end{tabular}

Table E-1. Direct Employment and Capacity Raw Data 


\begin{tabular}{|c|l|l|l|l|l|}
\hline 7 & $\begin{array}{l}\text { Calvert City, KY } \\
\text { EnviroPower }\end{array}$ & The Louisville Courier-Journal, August 12, 2001 & 60 & 500 & 4.09 \\
\hline 8 & $\begin{array}{l}\text { Potato Knob, TN } \\
\text { EnviroPower }\end{array}$ & Associated Press, May 9, 2001 & 70 & 524 & 4.25 \\
\hline 9 & $\begin{array}{l}\text { Nelson Creek, AK } \\
\text { Great Northern }\end{array}$ & Associated Press, March 18, 2004 & 75 & 500 & 4.32 \\
\hline 10 & $\begin{array}{l}\text { Seward, PA } \\
\text { Reliant }\end{array}$ & $\begin{array}{l}\text { Reliant Energy, Inc. Press Release, September 30, } \\
2004\end{array}$ & 81 & 521 & 4.39 \\
\hline
\end{tabular}

* Direct employment adjusted to remove mine workers from reported job totals

Once Table E-1 was filled in, a regression fit of 0 was performed to get a fit to the values for $\ln (\alpha)$ and $\beta$, which we will call $L A^{*}$ and $B^{*}$. The values for these two parameters for the data in Table E-1 are:

$$
\begin{array}{r}
L A^{*}=-0.638486076 \\
B^{*}=0.799615027
\end{array}
$$

Figure E-1 below shows the raw data and the curve fit for the production function of 0.

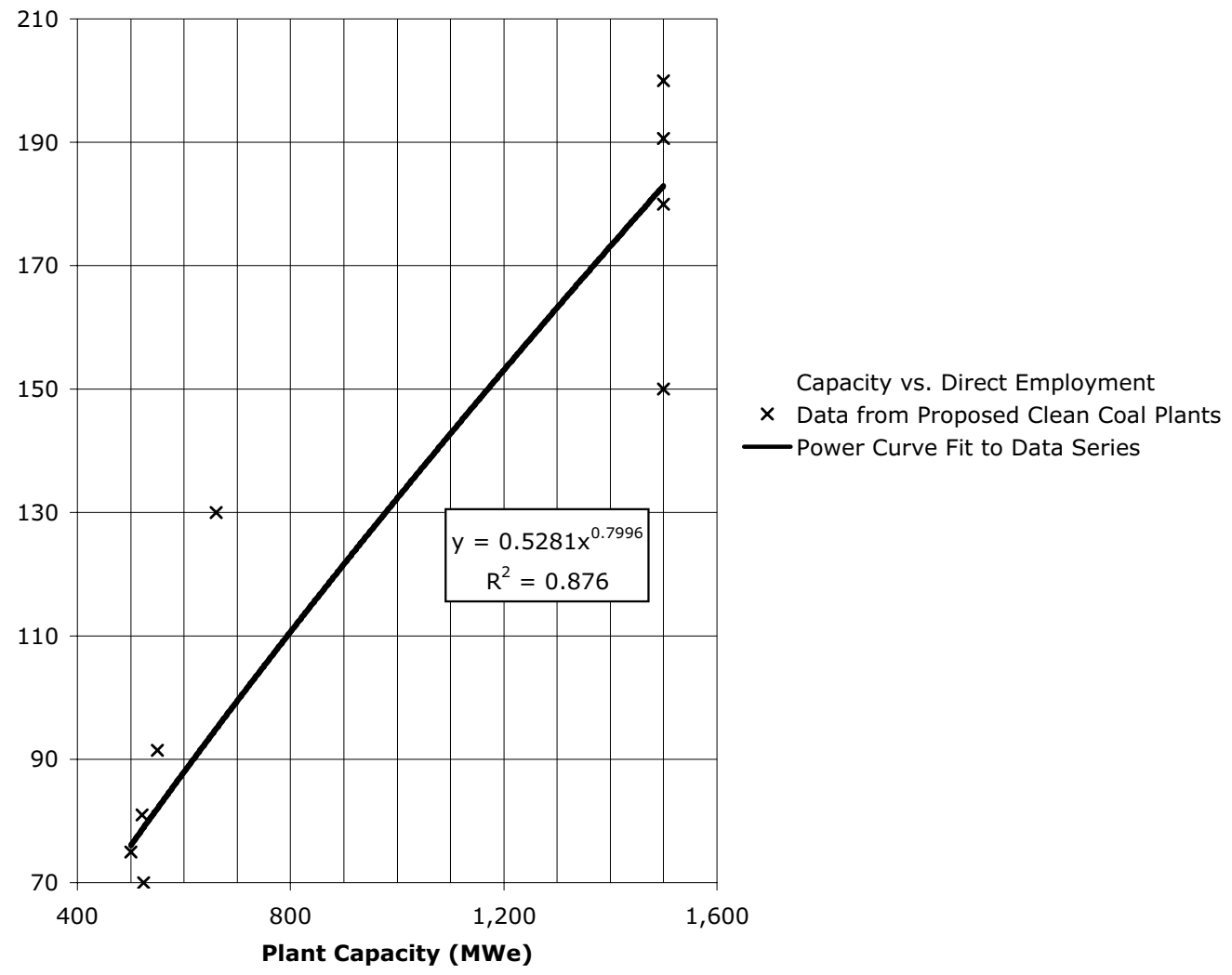

Figure E-1. Production Function Relating Direct Employment to Capacity for Clean Coal Power Plants 
If we want to predict direct employment for a given input value of $C$, we use the equation that relates the predicted value of $\ln \left(E_{\text {direct }}\right)$, which we will call $L E^{*}$,

$$
L E^{*}=L A^{*}+B^{*} \times \ln (C)
$$

From two-variable linear model theory [Johnston, pp. 38-41], this estimate actually is the mean of the logarithm of the direct employment level. The statistic

$$
t_{n-2}=\frac{\ln \left(E_{\text {direct }}\right)-L E^{*}}{s \sqrt{\frac{1}{n}+\frac{\left(\ln (C)-\frac{1}{n} \sum_{i=1}^{n} \ln \left(C_{i}\right)\right)^{2}}{\sum_{i=1}^{n}\left[\ln \left(C_{i}\right)-\frac{1}{n} \sum_{i=1}^{n} \ln \left(C_{i}\right)\right]^{2}}}}
$$

is distributed as Student's t with n-2 degrees of freedom where

$E_{\text {direct }}=$ the true value of the direct employment level

$n=$ the number of data points used to perform the regression with the data in Table E-1

$C=$ the capacity value for which we are making the prediction

$C_{i}=$ the capacity values of the data points used to perform the regression in Table E-1

$s=\frac{1}{n-2} \sum_{i=1}^{n}\left[\ln \left(E_{\text {direct }}(i)\right)-L A^{*}-L B^{*} \ln \left(C_{i}\right)\right]^{2}$, the estimate of the standard error estimate for the observation error from the regression.

Solving 0 for $E_{\text {direct, }}$, and substituting using 0 . we have

$$
E_{\text {direct }}=\exp \left\{L A^{*}+B^{*} \times \ln (C)+t_{n-2} S \sqrt{\frac{1}{n}+\frac{\left(\ln (C)-\frac{1}{n} \sum_{i=1}^{n} \ln \left(C_{i}\right)\right)^{2}}{\sum_{i=1}^{n}\left[\ln \left(C_{i}\right)-\frac{1}{n} \sum_{i=1}^{n} \ln \left(C_{i}\right)\right]^{2}}}\right\} .
$$

Substituting calculated values from Table E-1 into 0, gives the following relationship to generate a Monte Carlo sample for $E_{\text {direct }}$ for each new plant with capacity $C$ that comes on line:

$$
E_{\text {direct }}=\exp \left\{-0.638486076+0.799615027 \times \ln (C)+0.170177073 \times t_{8} \sqrt{\frac{1}{10}+\frac{(\ln (C)-6.70)^{2}}{2.560342949}}\right\}
$$




\section{E.2 DIRECT PLANT EMPLOYMENT, INDIRECT EMPLOYMENT, AND INDUCED EMPLOYMENT ANALYSIS}

The total of indirect and induced job estimate in Appendix B is calculated by combining the relationships of indirect and induced employment to direct employment as follows:

$$
\begin{aligned}
E_{\text {total }} & =E_{\text {indirect }}+E_{\text {induced }} \\
& =A_{\text {indirect }}+B_{\text {indirect }} E_{\text {direct }}+A_{\text {induced }}+B_{\text {induced }} E_{\text {direct }} \\
& =\left(A_{\text {indirect }}+A_{\text {induced }}\right)+\left(B_{\text {indirect }}+B_{\text {induced }}\right) E_{\text {direct }} \\
& =\left(A_{\text {indirect }}+A_{\text {induced }}\right)+\left(B_{\text {indirect }}+B_{\text {induced }}\right) E_{\text {direct }} \\
& =3699.8+2.15 \times E_{\text {direct }}
\end{aligned}
$$

We use 0 directly from the nuclear power plant regression results because there is insufficient data for the clean coal sources to perform a separate regression analysis. Table E-2 shows the results of applying 0 . This compares favorably with a press release from the Illinois Governor's Office (Canton, IL, March 13, 2003) that reports 4,000 jobs created for each new clean coal plant brought online.

Table E-2. Clean Coal Results for Total Indirect and Induced Employment During Operations

\begin{tabular}{|l|l|c|l|}
\hline i & Plant Name & Edirect & $\begin{array}{l}\text { Estimated Total Indirect and Induced Employment During } \\
\text { Operations }\end{array}$ \\
\hline 1 & Elwood, IL Indeck & 130 & $3,978.93$ \\
\hline 2 & Benton, IL EnviroPower & $91^{*}$ & $3,896.23$ \\
\hline 3 & Marissa, IL Peabody & $191^{*}$ & $4,109.05$ \\
\hline 4 & Benton, IL Franklin & 180 & $4,086.30$ \\
\hline 5 & Baldwin, IL Dynegy & 200 & $4,129.25$ \\
\hline 6 & Central City, KY Peabody & 150 & $4,021.88$ \\
\hline 7 & $\begin{array}{l}\text { Calvert City, KY } \\
\text { EnviroPower }\end{array}$ & 60 & $3,828.62$ \\
\hline 8 & $\begin{array}{l}\text { Potato Knob, TN } \\
\text { EnviroPower }\end{array}$ & 70 & $3,850.09$ \\
\hline 9 & $\begin{array}{l}\text { Nelson Creek, AK Great } \\
\text { Northern }\end{array}$ & 75 & $3,860.83$ \\
\hline 10 & Seward, PA Reliant & 81 & $3,873.71$ \\
\hline
\end{tabular}

\section{E.3 CLEAN COAL POWER PLANT CONSTRUCTION REGRESSION ANALYSIS}

We used the same relationship to be fit is the equation that relates plant capacity and construction employment as was used for direct employment during operations. Using classical economic production models, we let 


$$
E_{\text {construction }}=\alpha C^{\beta}
$$

where $E_{\text {direct }}$ is the direct employment at the plant, $C$ is the plant capacity in megawatts (MW), $\alpha$ and $\beta$ are coefficients to be fit. Taking logarithms of 0 , we have

$$
\ln \left(E_{\text {construction }}\right)=\ln (\alpha)+\beta \ln (C)
$$

which was used as the linear model for a linear regression fit with all of the direct employment and capacity data collected from various sources.

The regression fit is done using data from Table E-3 below.

\begin{tabular}{|c|c|c|c|c|c|c|c|}
\hline $\mathbf{i}$ & Plant Name & Data Source & $\mathbf{E}_{\text {construction }}$ & $\mathbf{C i}$ & $\ln \left(\mathbf{E}_{\text {construction }}\right)$ & $\ln (C)$ & $\begin{array}{l}\text { Construction } \\
\text { Timeline } \\
\text { (yr) }\end{array}$ \\
\hline 1 & $\begin{array}{l}\text { Elwood, IL } \\
\text { Indeck }\end{array}$ & http://www.illinoisbiz.biz/coal/ProjectSummaries.html & 1000 & 660 & 6.91 & 6.49 & 4 \\
\hline 2 & $\begin{array}{l}\text { Benton, IL } \\
\text { EnviroPower }\end{array}$ & http://www.illinoisbiz.biz/coal/ProjectSummaries.html & 600 & 550 & 6.40 & 6.31 & - \\
\hline 3 & $\begin{array}{l}\text { Marissa, IL } \\
\text { Peabody }\end{array}$ & http://www.illinoisbiz.biz/coal/ProjectSummaries.html & 1500 & 1500 & 7.31 & 7.31 & - \\
\hline 4 & $\begin{array}{l}\text { Benton, IL } \\
\text { Franklin }\end{array}$ & http://www.illinoisbiz.biz/coal/ProjectSummaries.html & 2000 & 1500 & 7.09 & 7.31 & - \\
\hline 5 & $\begin{array}{l}\text { Baldwin, IL } \\
\text { Dynegy }\end{array}$ & http://www.illinoisbiz.biz/coal/ProjectSummaries.html & 1500 & 1500 & 7.31 & 7.31 & $3-4$ \\
\hline 6 & $\begin{array}{l}\text { Calvert City, } \\
\text { KY } \\
\text { EnviroPower }\end{array}$ & The Louisville Courier-Journal, August 12, 2001 & 1000 & 1500 & 6.91 & 7.31 & - \\
\hline
\end{tabular}

Table E-3. Construction Employment and Capacity Raw Data

Once Table E-3 was filled in, a regression fit of 0 was performed to get a fit to the values for $\ln (\alpha)$ and $\beta$, which we will call $L A^{*}$ and $B^{*}$. The values for these two parameters for the data in Table E-3 are:

$$
\begin{aligned}
L A^{*} & =3.501988075 \\
B^{*} & =0.51071420
\end{aligned}
$$

Figure E-2 below shows the raw data and the curve fit for the production function of 0 . 


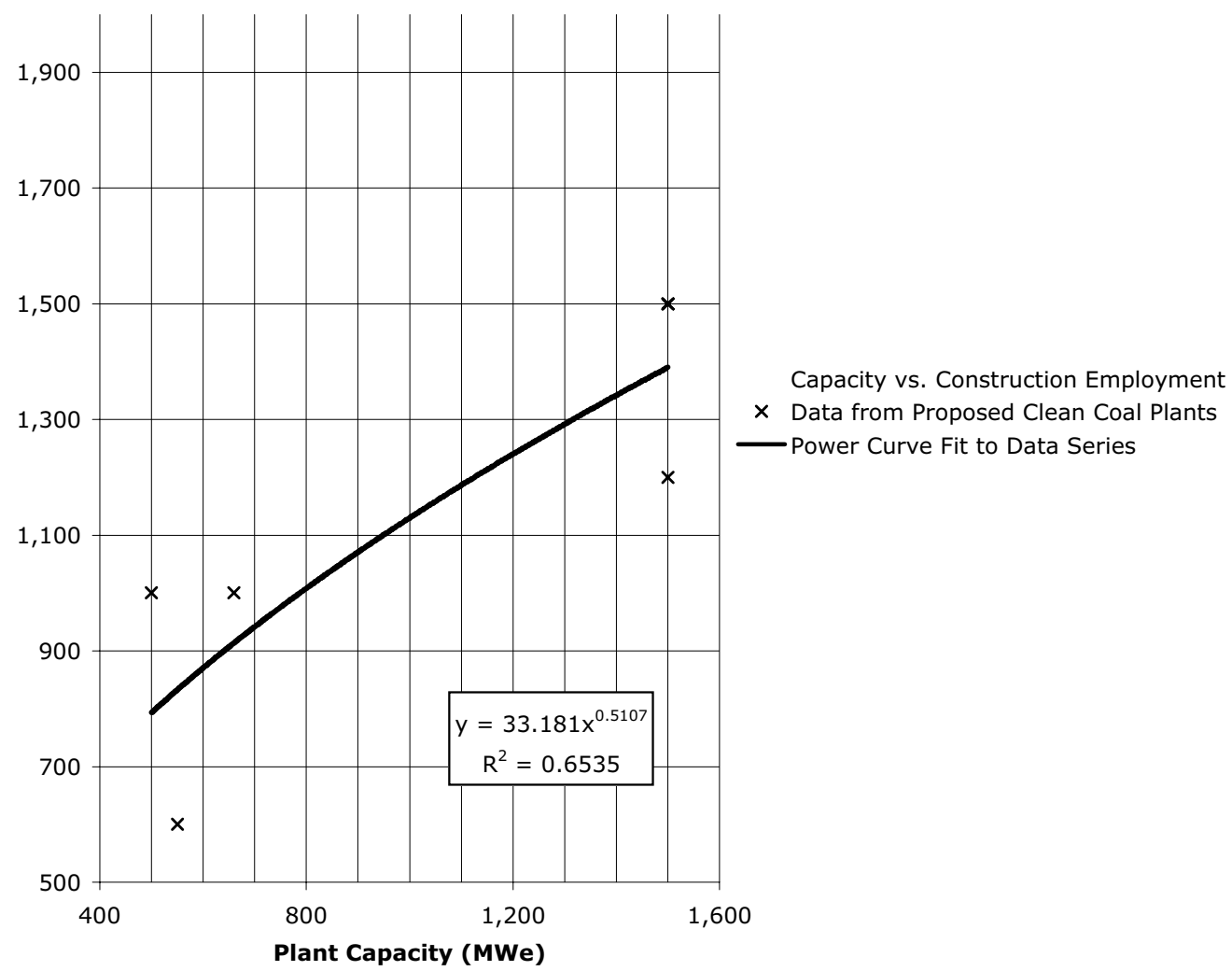

Figure E-2. Production Function Relating Construction Employment to Capacity for Clean Coal Power Plants

If we want to predict direct employment for a given input value of $C$, we use the equation that relates the predicted value of $\ln \left(E_{\text {direct }}\right)$, which we will call $L E^{*}$,

$$
L E^{*}=L A^{*}+B^{*} \times \ln (C)
$$

From two-variable linear model theory [Johnston, pp. 38-41], this estimate actually is the mean of the logarithm of the direct employment level. The statistic

$$
t_{n-2}=\frac{\ln \left(E_{\text {construction }}\right)-L E^{*}}{\sqrt[s]{\frac{1}{n}+\frac{\left(\ln (C)-\frac{1}{n} \sum_{i=1}^{n} \ln \left(C_{i}\right)\right)^{2}}{\sum_{i=1}^{n}\left[\ln \left(C_{i}\right)-\frac{1}{n} \sum_{i=1}^{n} \ln \left(C_{i}\right)\right]^{2}}}}
$$

is distributed as Student's $t$ with n-2 degrees of freedom where

$E_{\text {construction }}=$ the true value of the construction employment level,

$n=$ the number of data points used to perform the regression with the data in Table E-3, 
$C=$ the capacity value for which we are making the prediction,

$C_{i}=$ the capacity values of the data points used to perform the regression in Table E-3, and

$s=\frac{1}{n-2} \sum_{i=1}^{n}\left[\ln \left(E_{\text {construction }}(i)\right)-L A^{*}-L B * \ln \left(C_{i}\right)\right]^{2}$, the estimate of the standard error estimate for the observation error from the regression.

Solving 0 for $E_{\text {construction, }}$ and substituting using 0 , we have

$$
E_{\text {construction }}=\exp \left\{L A^{*}+B^{*} \times \ln (C)+t_{n-2} S \sqrt{\frac{1}{n}+\frac{\left(\ln (C)-\frac{1}{n} \sum_{i=1}^{n} \ln \left(C_{i}\right)\right)^{2}}{\sum_{i=1}^{n}\left[\ln \left(C_{i}\right)-\frac{1}{n} \sum_{i=1}^{n} \ln \left(C_{i}\right)\right]^{2}}}\right\} .
$$

Substituting calculated values from Table E-3 into 0, gives the following relationship to generate a Monte Carlo sample for $E_{\text {direct }}$ for each new plant with capacity $C$ that comes on line:

$$
E_{\text {construction }}=\exp \left\{3.501988075+0.510714208 \times \ln (C)+0.224959221 \times t_{6} \sqrt{\frac{1}{4}+\frac{(\ln (C)-6.83)^{2}}{1.558824635}}\right\}
$$

When comparing the curve fits in this section to the method described in Appendix D that uses a ratio of labor-hours for nuclear construction to coal plant construction for a given MWe capacity, the results are essentially the same for 2 significant digits. For the Stella model, we used the Appendix D ratio method, because it was based on detailed historical data analysis whereas the data used for the regression fit described above uses less detailed project summary data.

\section{E.4 MODELING THE RELATIONSHIP BETWEEN CONSTRUCTION EMPLOYMENT AND INDIRECT EMPLOYMENT}

In addition to indirect and induced employment resulting from direct plant employment, there also is indirect and induced employment from direct construction jobs during the period when a plant is being built. In essence the indirect jobs that result from construction are manufacturing jobs. Discussions with industry experts suggested that the coal plant equipment manufacturers are still strong in the U.S. and will utilize excess capacity to fill most — if not all — of the new equipment demand, so the indirect effect of construction jobs for cola plants was assumed to be negligible and was not modeled. 